The Social Condition of the British Community in Bengal, $1757-1800$.

Suresh Chandra Ghosh

Thesis submitted for the degree of Doctor of Philosophy, University of London.

$$
\text { July } 1966 .
$$


ProQuest Number: 11015584

All rights reserved

INFORMATION TO ALL USERS

The quality of this reproduction is dependent upon the quality of the copy submitted.

In the unlikely event that the author did not send a complete manuscript and there are missing pages, these will be noted. Also, if material had to be removed, a note will indicate the deletion.

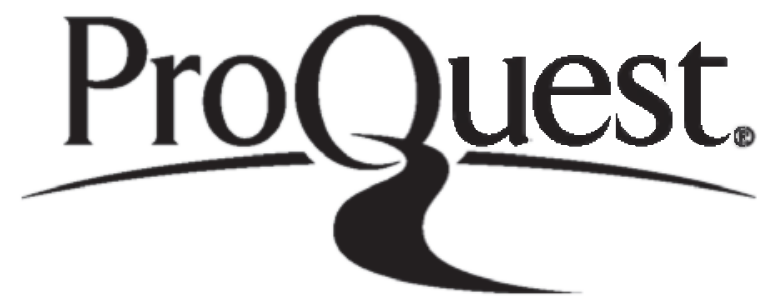

ProQuest 11015584

Published by ProQuest LLC (2018). Copyright of the Dissertation is held by the Author.

All rights reserved.

This work is protected against unauthorized copying under Title 17, United States Code Microform Edition (C) ProQuest LLC.

ProQuest LLC.

789 East Eisenhower Parkway

P.O. Box 1346

Ann Arbor, Ml $48106-1346$ 
This thesis sets out to examine the way in which the Inglish East India Company recruited servants, civil and military, for service in Bengal, the type of person selected, and the links they forged among themselves and with elements in the home administration. It also studies the growth of an Anglo-Indian community in Bengal. In its second part, it examines the pattern of life created for themselves by the servants of the Company in Bengal from both English and Indian elements.

The introduction discusses earlier work in this field and the aim of the thesis. The second chapter reviews the changing powers of patronage exercised by the Directors and the uses to which those powers were put. The third chapter notes the formation of families connected with the Company's service, shows their interconnections, and considers the effects which their formation had upon attitudes to India. The fourth chapter is devoted to a reconsideration of the causes leading to the creation of an Anglo-Indian community in Bengal, the numbers and classes of men involved, the development of institutions in Bengal to care for the offspring of mixed unions, and the attitude displayed towards Anglo-Indians by the home government of the Company.

The second part of the thesis attempts to relate 
the foregoing enquiries to the creation of a British social life in Bengal, and to show how elements taken from English and Indian society were fixed in varying proportions in that social life. Chapter five concentrates attention on the physical environment which the British community created around them, noting their adaptations to the Indian climate, while chapter six is concerned with the social life led within that environment. The conclusion briefly reviews the main themes of the thesis and the findings which it is hoped have emerged. 


\section{List of Contents.}

\section{Abstract \\ Abbreviations.}

Chapter I: Introduction.

\section{Part 1: The Structure of the Society}

Chapter II: Recruitment of the Writers and Cadets

Chapter III: The Development of the British Official Families.

Chapter IV: The Development of the Anglo-Indian Community.

Part 2: The Nature of Social Iife.
Chapter V:
Home Iife
Chapter VI:
Social Iife
Chapter VII: Conclusion. 
Appendices。

\section{IHat $\cdot 2$ Abbzeviatione.}

Table of the Thackeray Family。

II Ninety-Five

III

Excerpts from Wills showing the testators' provision for their Indian mistresses and natural children.

A selection from Bengal Inventories throwing light on British Life in Bengal.

Monthly wages of Household Servants as fixed by the Quorum of Zemindars in 1759, 1785-7 and 1801 .

The Daily Iife of an Englishman in Bengal.

The Daily life of an English lady in Bengal.

Bibliography

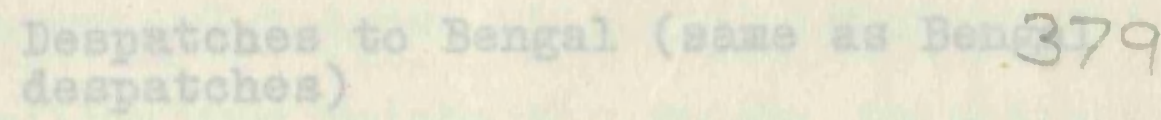

Buxopoun. Tnhabitouts in Bengal.

Evropeang in Tndila

Pactomy Records: Tettera to India

Howe Misoelianeous Beples

Parliamentary Fistory. (Pxinted)

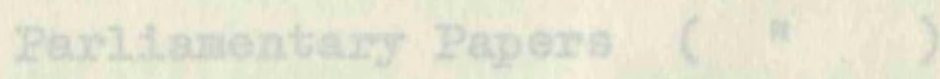

Pexsonal Records.

Secret Cowrt Minutes 


\section{Iist of Abbreviations.}

B.B.M.B.

B.C.S.

B.D.

B.I.

B.I.R.

B.W.

C.B.

C.P.

C.R.

D.B.

E.I.B.

E.I.

F.R.I.I.

H.M.

P.H.

P.P.

P.R.

S.C.M.

W.P.
Bengal Baptisms Marriages and Burials

Bengal Civil Servants

Bengal Despatches

Bengal Inventories

Bengal Letters Received

Bengal Wills

Court Books

Cadet Papers

Cadet Register

Despatches to Bengal (same as Bengal despatches)

European Inhabitants in Bengal

Europeans in India

Factory Records. Ietters to India

Home Miscellaneous Series

Parliamentary History (Printed)

Parliamentary Papers ( ") )

Personal Records.

Secret Court Minutes

Writers' Petitions 
INTRODUCTION 
Chapter I

In the middle of the eighteenth century the English East India Company's settlements in Bengal consisted of Calcutta, founded by Job Charnock in 1690, with its fort and three zamindari villages and the up country factories at Kasimbazar, near the provincial capital of Murshidabad, at Dacca, Luckipur, Malda, Rajmahal, Hooghly and at Balasore, the capital of Orissa, and Patna, the capital of Bihar. The subordinate factories each had a chief, a warehousekeeper, an accountant and several writers, and a small contingent of troops, with still smaller outlying aurangs or collecting points for goods, in charge of one or more junior servants of the Company. Over the whole provincial chain of factories and outposts there presided, at Calcutta, the Governor and Council of Fort William, with their more elaborate staff of commercial assistants, a small European garrison for Fort William, and a tiny marine establishment. The raison d'être of all these persons was the management and protection of the trade between Bengal and Europe, and between Bengal and other ports of Asia.

The numbers involved were still very small. The total Bengal establishment of civil servants of the 
Company, on the eve of Plassey, was only seventy-six, ${ }^{1}$ and, that of European officers and soldiers 260 at Fort William and approximately another 240 scattered among the up-country factories. ${ }^{2}$ The number of British nonofficial persons, those outside the direct services of the Company in all probability did not exceed a hundred. ${ }^{3}$ The picture is then one of ting knots of Englishmen in the up-country factories, barely noticeable on the fabric of Bengali society, and of one larger settlement at Calcutta, where the Company servants enjoyed extra-territorial rights, the security of a fort, and such European institutions as the Mayor's Court, established in 1726-27. In Calcutta, and at the larger out-stations English society was paternal in character, with the governor or chief one who "owed his position more to longevity and a fresh constitution than to anything else" ${ }^{4}$ - presiding over a

1. M.E. Monckton-Jones, Warren Hastings in Bengal, p. 34 .

2. S.C. Hill, editor, Bengal in 1756-7, vol. 1, pp. XXXIX - XI.

3. This impression is formed by comparing the above figures of military and civil servants with Hill's List of Europeans in Bengal in 1756 as well as with the later manuscript list of European inhabitants in Bengal.

4. T.G.P. Spear, The Nabobs, p. 6 : 
group of senior and junior merchants, factors and writers, chaplains and surgeons. These men worked together in the offices and warehouses of their factory, took their meals at a common table, seated according to their rank, and at night, when the gates of the for or factory shut upon them, slept on the premises.

The Company which sent these men to Bengal was a prosperous one, an important element in the growing overseas trade of Britain, and in the financial arrangements which linked the city of Iondon with the government. Its stock was widely held, but its management, the Court of Directors, was still mainly in the hands of leading Iondon merchants and of the shipowners who provided the shipping between Europe and Asia. The Company required Government support, since it held a monopoly which was jealously regarded by outsiders, but it was not subject to any great measure of control, though the ministry of the day was always glad to call upon the patronage wielded by the Company to extend its own management of political 'interests By 1803 the Company of the mid-eighteenth century had been transformed. In Bengal there had been a considerab] increase in the number of its civil servants, and a dramatic increase in the number and quality of its military servants. It still managed a large and expanding trade, and the 
commercial branch, with its headquarters at the Board of Trade in Calcutta and its commercial residents up-country, still sorted and baled cottons, and silks, and shipped out saltpetre from Patna as before. But the commercial branch was now overshadowed by a civil service responsible, as collectors and magistrates, or as judges of the district courts, for the administration of an empire which stretched from Chittagonj and Cuttack as far as Delhi, for it was from the revenues of these territories, and the profits of the China trade that the commerce between India and England was sustained. The handful of European troops, maintained as guards up-country and as garrison of Fort William had also grown to an army of perhaps five thousand men, with a further considerable army of European-officered native battalions, and a number of royal regiments on a tour of duty in India.

The prospects of all these Europeans had also changed vastly. The writers, factors and merchants who in the 1750's had drawn from $\$ 10$ to 40 a year, in salary, with free board and lodging from the Company, and who had looked to the profits of private trade to supplement this modest provision, were now members of a civil service which since 1793 had provided for annual salaries of up to $\$ 500$ after three years service in India, £l,500 after 
six and 8 ,000 after twelve, with the possibility of rising to 110,000 as a member of Council, or $£ 25,000$ as Governor-General. The army was much more modestly paid, with a Lieutenant drawing about £250 a year, and a Lt. Colonel some 1,500 , though even these sums were not unattractive by English standards. In addition there was now a Supreme Court at Calcutta, a royal court with judges appointed from England at very comfortable salaries. As befitted rulers of the country, the English were not only better paid than they had been half a century earlier, they had created the visible symbols of supremacy, new and splendid quarters in Calcutta, new civil lines and military centonments outside the Indian towns up-country.

In England, likewise, there had been notable changes. The new wealth and power of the Company had led the government to demand a share for itself in both. By the end of the eighteenth century, the management of the Company's affairs in India were shared between the Court of Directors and the Board of Control. Though the patronage of the Directors had not been invaded, a portion of it had by convention been placed at the disposal of the President of the Board, while the invasion of Parliament by members of the Company, and the intervention of the ministry in the elections to the Court had altered the uses to which 
the Company's patronage was put. The structure of the Court of Directors, and its relations with the Court of Proprietors had been altered by Parliamentary legislation, and its composition by the growth of a large body of returned Indian servants who had been administrators of great territories in India, and had amassed considerable fortunes there.

It is not the purpose of this thesis to trace the transformation of the Company in India from trading corporation to ruling power. Nor tomalyse the constitutional changes which took place in England between 1757 and 1800 in the relationship between the Company and Parliament. Both have already attracted the attention of historians and received their full consideration. The aim is rather to turn attention upon the Company's servants who effected the transformation in. India but who have been pushed into the background by their own achievements, to turn away from Clive, Hastings, Cornwallis or Wellesley to consider the mass of individuals through whom they worked. Bernard S. Cohn has commented:

$$
\text { "The diffusion of British institutions, ideas }
$$
and values and the spread of the English language and of British peoples are among the major events in modern history. The study of the effects of this diffusion in 
the New World, Africa, and Asia, if shaping political institutions in these regions has attracted many scholars, but the systematic and analytic study of the British themselves and of the societies and cultures they built overseas in their African and Asian colonies has thus far been neglected, except in the memoir and travel literature". ${ }^{1}$ The purpose of this thesis is to undertake such a study of the British going out in the service of the East India Company to Bengal in the years 1757 to 1800. It will be seen that it falls into two parts, the first a study of the recruitment of the Company's servants for Bengal, and the social system which they formed in Bengal, the second a study of the life they shaped for themselves in Bengal. The sources which have been utilised fall likewise into two main groups, for the first part official records, for the second that type of material which R.H. Tawney discussed in his study, Social History and Iiterature, that is to say, contemporary travellers' accounts, memoirs, letters, diaries, pamphlets and polemical works, newspapers and even paintings.

On these two aspects of the creation of a British community in Bengal, the former has so far attracted little

1. B.S. Cohn, The British in Benares, p. 169. 
attention. The fortunes of individual families who served the Company in India have been traced, and no biography fails to provide information about its individual subject. Again the work of C.H. Philips on the home government of the Company, supplemented by that of Lucy Sutherland, has thrown a flood of light upon the men in whose hands the power of patronage lay. But the only recent attempt to study the social composition of the Company's services in Bengal has been the article by B.S. Cohn, the British in Benares, which is concerned with the very last jears of our period and the first decades of the nineteenth century. It is hoped that by a systematic use of the Writers' Petitions and the Cadet Papers and Cadet Registers, in conjunction with the information already available on the personnel of the Court of Directors, a much clearer picture has been given than hitherto available of the methods by which the Company's servants were chosen, their origins and the system of interlinked families which they created in Bengal. Then in a further chapter, based in its analysis upon the very voluminous records of Bengal Baptisms, Marriages, Burials and Wills, the attempt has been made to create a clearer picture of the growth of Anglo-Indian or Eurasian community in Bengal, and to relate its fortunes to the circumstances of the Company's 
servants in India and the interests of the Directors at home. Several earlier studies exist, Sir John Kaye's article, "The English in India - our social morality", in the Calcutta Review and the works of H.A. Stark and T.G. Clarke, but these are not statisticaliy based, and seem in error both as to the causes for the growth of the Anglo-Indian community and as to the nature of the Directors attitude to it.

Much more interest has been shown by earlier writers in the social life which the British created for themselves in India. In the nineteenth century there appeared the Rev. J. Iong's Calcutta in the Olden Times, published in the Calcutta Review in 1860, and his Peeps into Social Iife in Calcutta a Century Ago, published in 1868, H. Blochman's, Calcutta during the last Century probably published in the same year, H.E. Busteed's Echoes from Old Calcutta, in 1888 and the Rev. W.H. Hart's old Calcutta, of 1895. Of these Dr. Busteed's was the most popular, and the most thorough, going through four 
editions in quick succession. ${ }^{1}$ In 1907, with the foundation of the Calcutta Historical Society under the scholarly, Rev. W.K. Firminger a further stage in the study of the different aspects of English lifewas reached. A number of excellent articles were to be published in the Society's Journal. In the same decade there also appeared Kathleen Blechynden's Calcutta Past and Present, (in 1905), and H.E.A. Colton's Calcutta Old and New which appeared two years later. These were followed many jears later by T.G.P. Spear's The Nabobs, covering India as a whole, and R. Pearson's the Eastern Interlude, published in 1954. Between them these works, despite their uneven quality, do provide a great deal of evidence of the manners, customs and habits of life of the British community in Bengal.

1. Lord Curzon paid this tribute to Dr. Busteed's work on the eve of its fourth edition:

"Since first I read this book on my way out to India I have never failed to find in its pages both a romance and an inspiration: a romance, because with the early days of British dominion in Bengal were interwoven the fortunes of famous men and women as remarkable for the vieissitudes of the lives as for their talents - an inspiration, because jour stimulating narrative mut have tempted scores of others, as it tempted me, to explore those obscure but prolific strata of the past from which you have extracted so rich a spoil". 
There are still however numerous points on which correction in detail is required, and more important, there is need to relate the changes in the pattern of life to changes in the methods of recruitment and the conditions of service of the Company's servants in a more systematic way. The attempt is therefore made in this thesis, by co-ordinating official records and contemporary accounts of many kinds, ${ }^{1}$ to achieve these ends.

1. In quoting from contemporary sources no attempt has been made to correct spelling mistakes. The generous use of capital letters in the originals has also been retained. 


\section{Part I}

The Structure of the Society 


\section{CHAPTER II}

THE RECRUITMENT OF WRITERS AIND CADETS

AND ITS IMPACT ON THE SOCIAL ORIGIN

OF THE OFFICIAL SECTION OF THE

BRITISH COMMUNITY.

Despite conflict with European rivals at sea, and Sir Jahn Child's abortive attempt at landward conquest, the East India Company for the first hundred and fifty years of its existence remained in essence a purely commercial body. It had no great territorial possessions and it maintained no more troops than were needed to secure the local defence of its trading posts and the dignity of its Presidents and Councillors. In the recruitment of its agents for the East it looked to merchant qualities: practical experience, a knowledge of book-keeping and foreign languages, a good hand and a good character. The Directors of the Company, themselves merchants with wide connections in the City and the other great trading companies, personally sought out and proposed suitable candidates, and in committee examined their character, ability and sufficiency. 
The Court Minutes of the Company in its early years show the care with which their merchants, factors and writers were chosen, especially the more senior men. Stress was placed upon previous service abroad, preferably in Spain, North Africa or the Levant, where a knowledge of Portuguese, Turkish and Persian, and of indigo and cottons could be acquired, useful in Asia. Stress was also laid upon good character, honesty and sobriety, and upon sufficiency: candidates came with testimonials from their previous employers and established their 'sufficiency' by entering into penalty bonds (for good behaviour) in substantial amounts and by investing considerable sums on their own account in the Company's stock. 1

Many of the early recruits were already experienced merchants when they entered the Company's service and their position and pay was individually negotiated. From 1674, however, the Directors sought to lay down a more regular scale of salaries at first appointment - £5 for an apprentice, £10 for a writer, $£ 20$, £30 and 40 for factor, junior and senior merchant

1. K.N.Chandhuri, The English East India Company, p. 74 et seq. 
respectively, rising to 500 for a President of one of the major settlements. It was also laid down in 1674 that promotion should be by seniority, after set terms in each grade, though until 1765 more senior men at intervals continued to be sent out. ${ }^{1}$ As before, servants on appointment had to sign covenants guaranteeing good behaviour, and upon promotion had to enter into penalty bonds of increasing amount. ${ }^{2}$

The selection of candidates continued to be made by the Directors after the union of the old and New Companies in 1708: candidates for employment secured nomination by one of the Directors and then submitted their petition to the full court for appointment. However, this procedure was evidently not always strictly pursued, for in 1714 the Court of Directors resolved:
"that for the future no petition be received from any person for any employment whatever in this Company's service, unless the petitioner be recommended by one or members of this Court; and that his or their names who do so recommend be mentioned in the Minutes of the court."

The petitions of candidates so nominated then went to The Eentral. Administralion...

1. B.B.Misra, ep.cit., pp.379-80.

2. Ibid., p.380. This is the origin of the covenanted service, the elite service in India.

3. F.C.Danvers et al, Menorials of Old Haileybury College, p.7. 
the Committee of Account which considered their qualifications and if found acceptable they were passed to the whole Court which voted for the various candidates. If appointed, a candidate had then to sign a covenant and furnish two securities in $£ 500$. In 1731, the Court again ordered the regular observance of these regulations, laying down:

"that in future all petitions for employment in the Company's service, either at home or abroad, be presented by some of the gentlemen in the pirection and that they speak to the same".

In the selection of the agents in the East the Directors exercised great care, for they were well aware that upon the ability of those they chose depended the success of the whole Company. But to attract good men they had to offer good terms. Initially, since in joint-stock operations it seemed impossible to follow the pattern employed in their European companies of paying agents a commission, the attempt was made to create a salaried service. Substantial salaries were offered and good service was rewarded by additional grants in return for a promise

1. Sir William Foster, John Company, p.21l et seq. 
not to engage in private trade on their own account. ${ }^{1}$ However, the confusion of over-lapping Joint Stocks, and in the depressed 1640's the creation of new separate voyages, made it difficult to control servants in the East whose masters were so fluctuating in membership. ${ }^{2}$ Private trade, though forbidden, steadily grew. Eventually the Company chose to try to regulate an evil it could not destroy, by allowing its servants overseas to trade with Europe in certain defined articles, and to an extent set out in 1632 by royal proclamation. 3 In addition to such regulated trade with Europe, the Company's servants in the East also engaged in the inter-port trade in Asia. When, during the civil war in England, the Directors were with difficulty able to maintain the Company in being, and again at the end of the seventeenth century, when interlopers and the General Society of 1698 broke the monopoly of the Company, private trade grew still further. Before the end of the century the salaries paid to the Company's

1. Chaudhuri, op.cit., p.76 et seq.

2. W.W.Hunter, A History of British India, Vo1.2., p. 164 .

3. Ibid., p.163. 
servants in India had come to seem a retaining fee rather than a living wage. ${ }^{1}$ The profits of private trade, not the $\$ 5$ allotted to apprentices by the 1674 regulations, were now the attraction, and the company's success in securing from the Mughal authorities the privilege of duty-free trade, in which its servants could share, only made the change more pronounced. But if hope of a lucky fortune had to some extent replaced the certainty of a substantial but regulated salary, those who entered the Company's service in India still had comparatively modest ambitions, not by any means always fulfilled. The patronage of the Directors was still that of merchants, not princes. The patronage was also limited in extent. In 1750 the total number of covenanted servants in the East was still tiny: perhaps forty in Madras and about as many in Calcutta, and still fewer in Bombay. In each settlement there was a handful of military officers, appointed by the Directors, and a body of freemen, merchants, artisans and servants, perhaps as numerous as the officials. ${ }^{2}$ Since British subjects

1. There were generous living allowances..Cf.Sukumar Bhattacharya, op.cit., pp.109-10 The East india Compd 2. T.G.P.Spear The Nabobs, pp.11 and 29-30 政. 
were only allowed to reside in the Company's settlements with the license of the Directors, they too in a way depended on their patronage, though a study of the lists of European inhabitants in Bengal in the late eighteenth century shows that many lacked the requisite license. ${ }^{1}$ The modesty of the prospects offered and the limited number of the posts to be filled in the East meant that the importance of the Directors' patronage was also modest.

From 1746 in Madras and 1756 in Bengal, however, the situation was rapidly and radically transformed. In both areas a military disaster to the Company was quickly followed by involvement in war and politics, by the achievement of military supremacy, and by the acquisition of large territory for whose administration the Company found itself responsible. The numbers of civilian servants of the Company steadily increased, the numbers of European officers and troops rose with dramatic suddenness, and for the first time royal regiments came to be employed in India. Of this enlarged scope for English activities, the servants of the Company took full advantage. As at home, war

1. Infra $\mathrm{Ch} . \mathrm{IV}$. 
was seen in Bengal in terms not only of glory, but of lucrative contracts, while the acquisition of political authority called out not only the administrative skill but also the greed of merchants. The years following Plassey and Buxar were a heyday of plunder and corruption: Richard Barwell, writing from Malda to his father can say,
"India is a sure path to competency. A moderate share of attention and your being not quite an idiot are ... ample qualities for the attainment of riches". 1

Or, as Henry Topham put it in 1765, the Company's civil service had been,
"the only certain track to a Fortune or preferment and much more in the Bengal establishment than any other".2

Thus the changes in Bengal and Madras considerably increased the importance of the patronage of the Court of Directors. The time had come when the fame of the Nabobs' riches was to make a writership or cadetship the goal of the ambitious younger sons of England, Ireland and Scotland.

1. Richard Barwell to his father, 26 November 7.765. "The Letters of Mr.Richard Barwell", Bengal: Past and Present, 1914, Vol.8, No.15, p.203.

2. Topham to Burrington, 22 September 1765. H.M. Vo1.765, p.153. 
The procedure of recruitment was still in 1757 unaltered, however, and the Directors who thus found their importance enlarged ${ }^{l}$ were still businessmen first, with interests in the City and in shipping, linked with Government by the Company's subscription to public loans, or, if members of Parliament, attracted by the prospect of Government contracts or other rewards for their support. There was, perhaps, an increasing number of persons with Indian experience - men like Stephen Law, Lawrence Sulivan and William Barwell - in the Directorate, but no rush as yet of adventurers seeking a place from which to defend or enlarge their interests in India.

The Court of Directors consisted of twenty-four members and since 1709 these had been elected annually by the Court of Proprietors from their membership. ${ }^{2}$

1. The patronage of the Directors had always covered posts in England and Europe, as well as in Asia. As Francis Baring pointed out in 1785 the Directors appointed not only writers and cadets but also chaplains, surgeons, ships' captains and marine officers, agents at ports, surveyors and labourers for the extensive Company docks and warehouses. This side of their patronage also grew, of course, though it attracted less attention than that relating to India.

Francis Baring to Court of Directors, 11 April 1785; C.B., Vol.93, p.1147.

2. Peter Auber, An Analysis of the Constitution of the East India Company, pp.196-7. 
It was necessary to hold $£ 1,000$ stock and to have held it for at least one year in order to be a qualified Proprietor entitled to vote. ${ }^{1}$ The necessary and formal qualification for election to the Directors was the possession of $£ 2,000$ of India stock and any Director who allowed his stock-holding to fall below that amount automatically disqualified himself. ${ }^{2}$ The Regulating Act of 1773 introduced a system of election whereby six Directors were annually chosen to replace six retiring Directors, the latter not being eligible for re-election until the following year. The Directors, therefore, held office for four years and then went out by rotation, on a sort of enforced holiday, for a year. The object of this change in the election of the Directors was to strengthen the authority of the Court of Directors and to produce stability in the Council and measures of the Company by extending the duration of their office. ${ }^{3}$ The Act also laid down that, as before, a Chairman and Deputy Chairman were to be chosen by ballot at the first court of

1. Ibid., p.349. A Proprietor with $£ 3,000$ worth of stock was entitled to two votes, with $£ 6,000$ to three votes and with $£ 10,000$ and upwards to four votes.

2. Ibid., p.197.

3. Ibid., $\quad$ pp.205-6.13 Geo.3, c.63, s 1 . 
Directors held after the annual election. ${ }^{1}$ Despite free and open elections, the court always remained very largely co-optive and it was customary for the Directors in office to inite to ensure the return of the six Directors out by rotation. ${ }^{2}$ As Professor Philips has pointed out, in practice the Direction has consisted of thirty members who were virtually elected for life. ${ }^{3}$

How did men seek to secure selection to this small body of Directors? Before 1773 all the Directors were elected annually, but even then it was difficult for anyone not on the retiring Director's house list to force his way in. Lucy Sutherland has amply demonstrated how difficult and how expensive contests became in the years after Plassey, as personal became tied with political interests. After 1773, when the Court became, in effect, a co-optive body of members elected for life, there was the added problem that only death or voluntary retirement provided effective openings for new entrants. The struggle when a vacancy occurred was the more desperate

1. Auber, op.ç̄t., p.199.

2. C.N.Parkinson, Trade in the Eastern Seas, 1793-1813, p. 16 .

3. C.H.Philips, The East India Company 1784-1834, p.5. 
as a result. Three things were then necessary for a successful contest. First, a candidate for election to the Direction had to prepare himself long before any expected vacancy occurred. He had to carry on an expensive and extensive canvass and enlist the support of all his friends. An arduous preparation was necessqry not only for a new candidate but even for one who was "out by rotation" and expecting his return to the Direction shortly. 1

Secondly, the candidate had to enlist the support of one of the two "interests" - the City and Shipping Interest and the Indian Interest - in the Company. The City and Shipping Interest consisted mainly of persons who had risen to importance through their connection with the Company at home. They were Directors, Proprietors, Captains of Indiamen, Shipowners and Ships' Husbands, many of whom were influential merchants or bankers. The retired British Civil and Military servants from India and their relatives formed the Indian Interest. 2 No one could hope successfully to contest an election to the Direction

1. Scott to Clarke, 24 July 1798, H.M. Vol.730, p.93. 2. Philips, op.cit., pp.23-4. 
without support from one of these two interests. 1

Finally, after 1784 the candidates had to enlist the support of Dundas, the President of the Board of Control. Between 1788 and 1795 six new men were introduced to the Direction and all were Dundas' friends. 2 David Scott told William Petrie, whose brother John wanted to contest an election for the Direction, that if he failed to obtain Dundas' support, it would give him "trouble without a chance of success". 3 An unsuccessful candidate for a previous election to the Direction, like George Dallas, could hope to "return with Confidence to a Career" only with the support of Dundas. 4 And so Dundas found it necessary to keep a waiting list of candidates for election to the Direction. 5 Occasionally he went so far as to propose the House List ${ }^{6}$ or introduce new names in it. 7 Dundas' support was

1. Scott to Campbe11, 15 November 1795. H.M. Vol. 728, pp.263-5. Also A.T.Embree, Charles Grant and British Rule in India, p.125.

2. Philips, op.cit., p.62.

3. Scott to Petrie, 28 December 1794, H.M., Vol.728,p.3. Also C.H.Philips, editor, The Correspondence of David Scott, Vol.1, p.14.

4. Dallas to Dundas, 22 February 1798. Quoted in the lett of 11 February 1800, H.M., Vol.731A, p.605.

5. Scott to Saunders, 12 March 1795, H.M. Vo1.728, pp. 69-70.

6. Dundas to Scott, 28 March 1800, H.M., Vol.731A, pp.107-8.

7. Dundas to Lushington, 22 April 1795, H.M.Vo1.67, pp. $107-8$. 
important inasmuch as it also implied the support of Pitt as was the case with the election of Charles Grant in 1794, which became, to quote Grant's words, "a thing of course". 1

The case of Sweny Toone, a retired Bengal Military officer, illustrates all the points discussed above. In 1795 Toone had declared his intention of entering into the Direction. Early in 1798 Toone wrote to Warren Hastings that he wanted to contest the vacancy occurred by "the Death of Poor Irwin" and that he could count on the support of sixteen members of the Court of Directors. His opponents were Plowden, Huddlestone and Thornton. "May I entreat the favour of you," he requests Hastings, "to write to your Friends ... The experiences I have of your goodness, assures me of your support". 2 Accordingly Hastings launched upon an extensive postal canvass for Toone, ${ }^{3}$ while the candidate himself organised a committee in London ${ }^{4}$ and engaged himself from seven in the morning till twelve midnight. As he says, "Wife, children - all are abandoned for the object of my present pursuit". 5

1. Grant to Scott, 4 November 1793. Mss.Eur. F 18/1 K 191, pp.83-9.

2. Toone to Hastings, 14 February 1798. W.H.P., AddZ.Mss. No.29175, pp.364-5.

3. Ibid., pp.385, 389,391,393,399, 402-3, 405-6, 409, 419-21. Hastings gathered a considerable number of votes for Toone.

4. Auriol to Hastings, 22 Feb.1898, Ibid., p.397. Toone to Hastings, 22 Feh $1798 . \overline{\text { Thid }}=395$. 
Toone only finally bec ame confident of success when, on visiting Dundas, he was assured of his warmest support, ${ }^{1}$ and hence that of the City and Shipping interests in Parliament. ${ }^{2}$ As the election approached, though he had seen many battles in India, Toone became increasingly nervous. 3 Nevertheless the 6 th March saw him win the election with a clear margin of 217 votes over his nearest rival. ${ }^{4}$

The motives which led men to make such efforts to secure election to the Court of Directors were doubtless as diverse as those which took others into Parliament. The salary of $\$ 250$ a year ${ }^{5}$ was probably not a principal attraction to men who were prosperous merchants, or as the century progressed, men who had acquired a competence or fortune in India, expecially as a Director

1. Dundas to Scott, 15 February 1798, H.M.,Vo1.731A, p. 517 .

2. Toone to Hastings, 22 February 1798, W.H.P., Addz.Mss. No.29165, p.395.

3. Toone to Hastings, 27 February 1798, Ibid., p.417.

4. Toone to Hastings, 5 March 1798. Ibid., Addz.Mss. No.29176, p.6. The letter was posted on the 6 th March after the result of the election was out.

5. The Chairs received $\$ 350$ per annum. See speech of Mr. Charles Fox in the debate in the Commons on his India Bill, 3 December 1783, P.H., Vol.24, Col. 6 . 
who wished to become influential in the Company had to give much time to committee work. Men who had served in India went into the Direction to direct events and policies which had become deeply important to them, or, as in the case of Clive, Johnstone and Sykes, to defend private interests built up in India. Others saw in the Direction a means of serving their business interest in London and abroad, and still others saw it as one route to a seat in Parliament. But all, it may be safely assumed, saw in election to the Court of Directors the key to control of valuable patronage which could be put to use in a variety of ways and to a variety of ends.

That patronage had come to include the command of armies, the administration of provinces, as well as control of a new lucrative commerce. How valuable it seemed to contemporaries can be seen first in the efforts which were made by government to 'manage' elections to the Directorate, and then in 1783 to seize it. In that year Fox and Burke introduced bills whilch would have transferred patronage from the Directors to seven commissioners nominated by government. $^{1}$ The proposal met with violent opposition

1. Philips, op.cit., p.23. 
from the Company, as could be expected, but it also raised widespread fear that Indian patronage would be exploited to undermine the whole balance of the British Constitution. $^{1}$ It was upon such grounds, whether they were inflated or not, that Pitt was able to secure the rejection of the bills in the House of Lords. By Pitt's own subsequent measure, the India Act of 1784 , political control was achieved and the national interest served by the creation of the Board of Control, and by giving to the government the power to disapprove, and hence to control, the appointment of Governors and Commander-in-Chief to the three Presidencies. But all other patronage was carefully left at the disposal of the Court of Directors as before. ${ }^{2}$

In respect of Indian appointments this meant that the Directors continued to appoint and send out writers and cadets according to the annual return of vacancies transmitted by the three governments in India. ${ }^{3}$ While there was a wide variation in the number of appointments

1. Robert Grant, The Expediency Maintained, p.251 et seq.

2. Philips, op.cit., p.33.

3. 33 Geo.III, C.52 Sec.59. Auber, op.cit., p.630. 
made annually, the average was about $150,,^{1}$ of which thirty would be writers and the rest cadets. ${ }^{2}$ This was a privilege which the Directors were not only allowed to enjoy after 1784, but which they guarded jealously. Thus when Cornwallis recommended that the Company's army should be merged with that of the King they took strong exception to the idea mainly because it meant loss of patronage over the army. 3

In the second half of the eighteenth century the Directors distributed among themselves their share of patronage according to their seniority in the Direction. The Chairs and the nine senior members of the Court who served on the Committee of Correspondence 4 enjoyed the Iion"s share. Thus in 1776 the Chairman and his Deputy each got two Bengal and two Madras writerships, the nine members of the Committee of Correspondence got one Bengal writership each, eight Directors got one Madras. writership each and five one Bombay writership each. 5 In 1778 out of forty-seven writer-

I. Robert Grant, op.cit.,p. 286 .

2. Ibid.,p. 281.

3. Philips, op.cit., p.90.

4. Ibid., pp. 12-13. This was the most important Committee in the Direction, and was only reached after many years of service in the court.

5. W.P., Vol. 8. Enclosed at the end of the petitions for 1776 . 
ships the Chairman and his Deputy each had eight, nine members of the Committee of Correspondence two, and the other Directors one each. ${ }^{1}$ In 1780 , the Chairman got three Bengal, one Madras and one Bombay writerships, the Deputy Chairman four Bengal and one Madras writerships, each of the nine members of the Committee of Correspondence one Bengal writership, and of the remaining thirteen Directors, three got one Bengal and one Madras writership each; six, one Madras writership each; two, one Bombay writership each and two did not have any share. ${ }^{2}$ Thus the senior members of the Court got not only a large but also the most valuable share of the patronage - the appointments for Bengal which were greatly coveted in the years after Plassey because of the enormous fortunes to be made there. 3

After the establishment of the Board of Control in 1784 , the Court of Directors put at the disposal of the Board a share of its patronage, though this was never uniform until 1799. Thus William Pitt got one Bengal writership for each of the two years, 1791 and

1. Danvers, op.cit., p.10.

2. W.P., Vol.9, 1780. Enclosed at the end of the petitions for 1780 .

3. See above, 
1792. ${ }^{1}$ In 1793 only Dundas got one Bengal writership. ${ }^{2}$ In 1794 Pitt got two Bengal writerships and Dundas one. ${ }^{3}$ After 1794 the Court increased the share of the Board to four and they were all given to Dundas. 4

The Board's share was utilised by Dundas in sending young Scotsmen to India. A few eeks after the establishment of the Board of Control, Lord Sydney, an English member of the Board, wrote complaining of the undue number of scotsmen who were receiving appointments. ${ }^{5}$ The second Earl of Minto told Lord Stanhope, the historian, that there was scarce a gentleman's family in Scotland, of whatever politics, that had not at some time received rome Indian appointment or some act of kindness from Dundas. ${ }^{6}$ This process of "Scotticising" India, though exaggerated in the minds of Dundas' contemporaries, ${ }^{7}$ would have been

1. W.P., Vol.12,1791, No.13; and Smith to Ramsey, 19 June 1793, W.P., Vol.13, 1793, No.24.

2. Hepburn to the Court of Directors, 18 March 1793. Ibid., No petition number can be traced.

3. W.P.,Vo1.14,1794. Nos.31 and 47 for Pitt and 43 for Dundas. 4. W.P. Vol.15, 1796-7, Nos.45,56,35,10 for 1796 and

5. J.A.Lovat-Frqser, Henry Dundas, Viscount Melville,p.19

6. E. \& A. Porritt, The Unreformed House of Commons, Vol.2, p.16.

7. Holden Furber, Henry Dundas, First Viscount Melville, $1742-1811, \mathrm{p} .32$. 
impossible had Dundas been restricted to his own direct share of patronage. However, he was often able to call upon that of members of the Court of Directors to supplement his own. An example of 1800 will indicate the process, revealed in one of his letters:

"I am much obliged to your for your Attention to my encumbered list. I am well aware of the Calls which must be upon the Representative of a District of Scotch Boroughs, independent of your many other connections, - I will not therefore call upon your two Cadets unless I find it absolutely necessary for me to do so.

I am so over head and ears in embarrassments with regard to writerships, that I am much obliged to you, for the hint you give me respecting Sir John Burgess $1 \%$ a Director7 and have aviled myself of it."l

Thus the amount of available patronage for any year was distributed among the Directors on the basis of their seniority in the Direction. David Scott, the Chairman of the Court of Directors, said in 1802 that in practice each of the Chairs had three times the patronage of the ordinary Director. ${ }^{2}$ This privilege was jealously guarded by the senior members of the Court. Thus in the mid-eighties of the eighteenth century, the scheme of Lawrence Sulivan, Director of

1. Dundas to Scott, 26 December 1800. H.M. Vol.731A, pp. 675-6.

2. Scott to Kellie, 29 May 1802, H.M., Vol.731, pp.6-7. 3. C.I.Phizips, op-oit, pp.44-5. 
the East India Company, for reducing the number of committees of the Court of Directors from twelve to three was vetoed by the Chairs, Devaynes and Smith, simply because it proposed to divide the Company's patronage equally among the members of the three committees, Political, Military and Commercial ${ }^{\ddagger}$ without reference to the seniority of the Directors.

After 1799 a rule emerged which, without altering the share of the Chairs and the Board, divided the patronage into twenty-eight parts. Each Director received one part, the Chairman, the Deputy Chairman and the Board of Control each received two parts. 32 This plan of distribution was first roughly followed in $1800 / 1801$ with regard to the nomination of Cadets for India. Each Chair got thirty-nine Cadet nominations, each Director except Manship who got nineteen nominations, received eighteen, the Board thirty-six and the Lord Lieutenant of Ireland seven. ${ }^{3}$ The precedent of $1800 / 1801$ was subsequently followed ${ }^{4}$ but was not applicable to the period before 1799 as Professor Philips seems to suggest.

7. Seot to Ket1ie, 29 May 1802.14., Vol.731, pp.6-7

1z. C.H.Philips, op.cit., pp.44-5.

23. Grant, op.cit., pp.271-2.

34. C.R., Vol.3, Enclosure at the end of the list of cadets for 1802 .

4.5. Astell to Dundas, 14 Nov.1810. H.M.Vol.817,pp.996-9. 56. Philips, op.cit., p.15. Professor Philips draws his conclusion from the study of the plan for the distribution of patronage for the year 1810. See H.M. 
How, it may be asked, did the Directors use the patronage thus apportiohed among them? One answer is that, believing that charity begins at home, the first care of the Directors was to provide for their own families. The case of Lawrence Sulivan is a typical example of the way in which a Director could provide for his family. Sulivan sent his only son stephen, his three brothers, Benjamin, John and Richard, and the sons of Benjamin Sulivan of Dromeragh, County Cork, attorney-at-law and Clerk of the Crown for the Counties of Cork and Waterford, to the East. All entered the civil service of the Company except Benjamin, who went to Madras as a barrister in $1777 .^{1}$ In 1773 Warren Hastings was to complain it was difficult to control the work of the collectors, because among them there were "so many sons, cousins or eleves of Directors." 2 Moreover the Directors were careful to I. Lucy S.Sutherland, The Bast India Company in the Eighteenth Century Politics, p.59.

2. Hastings to Dupre, 6 January 1773. Rev.G.R.Gleig, Memoirs of Warren Hastings, Vol.1, p.269. As the Chinese writership was extremely valuable, of the twenty persons stationed there before $20 \mathrm{July} 1796$, twelve were sons of Directors. The resolution of $20 \mathrm{July} 1796$ limited the number of Directors' sons who might receive China writerships to eight, but this was rescinded on 24 February 1808. Sœ the dissent of five Directors to the resolution of 24 February 1808, 2 March 1808. C.B., Vol.116A, p. 1344 . 
choose the plums of the service for their children. Because appointments in the civil service offered more opportunities of making money than those in the military service, there was no subject on which the Directors were "so jealous as that of appointment of writers". 1 It was often a writership which they bestowed on their sons and nephews, or on the families of their most intimate friends. They also used their authority to give precedence in rank to their sons, ${ }^{2}$ who might go as factors instead of as mere writers, ${ }^{3}$ and they were ready also to secure their rapid promotion once they had reached India - as may be seen in the career of Jonathan Duncan. 4

A small number of Directors seem to have used their patronage to secure a direct pecuniary return, by a sale of appointments. This was scarcely against the ethics of the day, for everything from a menial position to a Iucrative office was advertised in the contemporary newspapers. ${ }^{5}$ During the debate in the Commons on Fox's

1. Scott to Hastings, 14 May 1784. W.H.P.,Addz.Ms . No.29163, p.424.

2. Letter to Court, 9 May 1782. B.A.Saletore, editor, Fort William - India House Correspondence, Vol.9, pp.311-2.

3. Colebrooke to the Chairman of the Court of Directors, 12 October 1776, W.P., Vol.8, 1776, Enclosed after petition No.23.

4. V.A.Narain, Jonathan Duncan, pp.10-2.

5. James M.Holzman, The Nabobs in England, p.22. 
India Bill, Sir William Dolben pointed out that there were advertisements in the public press offering £1,000 for a Bengal writership. ${ }^{1}$ Nevertheless any blatant misuse of patronage of this sort was frowned on by the Court of Directors, and when a case of sale of a writership occurred in 1770 , they set up a select Committee to investigate it. ${ }^{2}$ They revealed that a certain Mrs. Woodington was to have received five hundred pounds or guineas for securing, through the influence of Mrs. Margaret Brown-Gooch, the nomination from the Director Edward Holden Cruthenden of a Madras writership for Joseph Baker. In this Mrs. Gooch, who was governess to Cruthenden's children had succeeded. 3 The enquiry also revealed another Director, William James had received a letter in December 1770 from Mr. Joseph Cruthenden, offering him money for the appointment of another young man as a writer in Bengal. 4

No direct action seems to have been taken in these two cases, but the Directors sought to check

1. 3 December 1783. H.H., Vol.24, Col.5.

2. C.B., Vol.79, p.364.

3. Ibid., p.406.

4. Ibid., pp.410-1. 
the abuse of patronage for pecuniary benefit by adopting two resolutions. First they resolved that the disposal of offices under the East India Company for pecuniary considerations not only reflected the greatest dishonour on the Court of Directors, but essentially affected the credit and interest of the said Company. Secondly it was declared that any person who should be directly or indirectly concerned either as principal or as agent in such unwarrantable and destructive practices was held to be unworthy to hold any office under the East India Company. The Directors decided that these resolutiohs should be read in the first Court of Directors after every annual election and should be treated as standing orders. 1 As a result Cruthenden resigned in June 1771.2

1. S. Vol.79, pp.410-1.

2. C.H. \& D.Philips, editors, "Alphabetical List of Directors of the East India Company from 1758 to 1858", Journal of the Royal Asiatic Society of Great Britain and Ireland, London, 1941, p.329. The enquiry of $1770-1$ was the first official enquiry undertaken by the Court of Directors to investigate the abuses of patronage. The latest writer on Charles Grant, A.T.Embree, commits a mistake when he says, "The appointment of a committee by the Court of Directors in 1798 to investigate the alleged abuses was the first official action the Company had ever taken." See p.179. In fact, the investigation of 1798 was the third official enquiry undertaken by the Company before 1800 . Embree's source is C.N.Parkinson (p.368) who is equally wrong. 
Despite these resolutions the sale of writerships and cadetships went on. Charles Grant wrote in December 1772 to his uncle saying that he had purchased his appointment as a writer at "no less than five thousand pounds" from the Director, Henry Savage, who gave it to him at the request of Richard Becher. ${ }^{1}$ It is in the irony of history that this same Charles Grant, as a Director, was to take a leading part in enquiry into the sale of patronage in 1798. Grant seens to have paid rather heavily, for in 1773 writerships were said to have a cash value of $£ 2,000$ to $£ 3,000,{ }^{2}$ at which latter figure they continued to be advertised in the newspapers until the end of the century. Hickey relates that when Lord Cornwallis asked Colonel Auchmuty how he had managed to get two of his sons into the civil and another into the military servide of the Company, the Colonel replied, to the bewilderment of the GovernorGeneral: "By my soule I had many friends there, sure

1. Grant to his uncle, John, 14 December 1772. Henry Morris, The Life of Charles Grant, pp.28-9. The fact of purchasing a writership by Grant has not been mentioned by Embree though Morris is one of his primary sources for his work. See p. 43 .

2. Public Advertiser, London, 2 June 1773. Quoted in Holzman, op.cit., p.22. 
enough, staunch ones too, no fewer than five thousand, my Lord!" A little later he explained, "I gave the lads of Leadenhall street : the Directors five thousand guineas ... for the writerships in Bengal for my two eldest whelps, and so in the generosity of their hearts they threw a cadetship into the bargain for my youngest spalpeen. "I We may note also that Directors were thought open to a bribe in matters of promotion of men already in the service in India. Richard Barwell in 1769 spent $£ 10,000$ to accelerate his promption to the Chiefships of Patna and Decca, which he eventually got in $1771-3 .^{2}$

On 22 September 1790, at a secret meeting of the Court of Directors, another enquiry into the sale of patronage was conducted on the grounds that "a Report prevailed out of doors, that a Nomination for a voyage had been obtained for pecuniary consideration." John Woodhouse, a Director, was accused of selling this post to Captain Alexander Gray of the Indiaman Phoenix. 3

1. William Hickey, Memoirs of Willian Hickey, (edited by Alfred Spencer), Vol.4, pp.109-10.

2. Barwe11 to his sibter, Mary, 20 January 1769. The Letters of Mr.Richard Barwell in the Journal of the Calcutta Historical Society, 1910, Vol.5, p.175.

3. S.C.M., Vol.7, No pagination. 
This investigation came to an abrupt end with the resignation of John Woodhouse from the Direction on 1 February 1791, but the whole proceedings leave no doubt that he had sold his nomination for the voyage directly to Captain Gray.

Because of the consciousness that patronage was being sold, Parliament imposed upon the Directors, at the time of the renewal of the East India Company's Charter in 1793, an oath to be taken by each one of them within ten days after his election to the Direction, that he would not derive any pecuniary benefit directly or indirectly from the use of his patronage. ${ }^{1}$

Later events show the inadequacy of such a check., for on 25 April 1798 the Court of Directors felt compelled by persistent and detailed charges of abuses in the nomination of writers to set on foot yet another enquiry. This time the enquiry dragged on, without

1. 33. Geo.III C.52. f.160. Report from the select Committee on East India Patronage, 2 March 1809. See P.P.(H.C.), 1809.\#.91, Vo1.2., p.489.

2. N.K.Sidhanta makes a sweeping and misleading. statement when he says in his foreword to Roy that the sale of pationage was stopped by the Act of 1793. See Roy, op.cit., p.vii. The Civil Servi. ce in ladia, p.vii. 
any positive success, until 25 February 1800 when it was abandoned. ${ }^{1}$ It had one important result, however, in a change in the procedure of nomination. Hitherto Directors had given their nomination cards to the applicants of their choice, and had left it to be presented by the candidate to the clerks at the India House. It would seem that some of these cards, sometimes even handed over without the candidate being named, had been sold to third parties. Now, on the recommendation of the Committee, the Court decided that in future Directors must fill in the name of the candidate on his card, and when he appeared before the Court, swear that this was the person to whom he had given his nomination. The Director was to state that he had not received any pecuniary benefit, direct or indirect from his nomination and the candidate was to swear that he had not given any "corrupt confidence" for his appointment. ${ }^{2}$

1. Report from the Select Committee on East India Patronage, 2 March 1809. P.P.(H.C.) 1809, \# 91, Vol.2, pp.490-2; H.M., Vol.67, pp.111-5, 117-23, 133-4 contain details about this enquiry. A.T. Embree has not referred to this source, but, for a detailed discussion why this enquiry in which Charles Grant played a leading role failed, sæp.180 et seq.

2. Report from the select Committee on East India Patronage, 2 March 1809. P.P.(H.C.), 1809, \#91, Vol.2 p.490. For example see w.P., Vol.16, 1799, Any petition. 
This measure seems to have ended any direct involvement of the Directors in corrupt practices. When in 1809 a Parliamentary enquiry was made into gross abuse of the patronage and confidence of George Woodford Thelluson, a Director and an M.P., it was revealed that between 1800 and 1808 sixteen cadetships and three writerships had been sold at prices ranging from $£ 150$ to $\$ 525$ and $£ 3,000$ to $\$ 3,500$ respectively, but in no case could any Director be directly accused of a sale of patronage. The Committee accordingly reported:

"It is a satisfaction to your Committee throughout the whole evidence; to remark nothing which traces any one of these corrupt or improper bargainings to any Directors, or induces a reasonable suspicion that it was done with the privity or connivance of any Member of the Court." 1

This report was welcomed by the Court of Directors as being the result of a "greater degree of circumspection in the appointment of the East India Company". 2 The evidence of such abuse of patronage is obviously incomplete, but it is doubtful if more than a small proportion of appointments were secured by such direct abuse of the Directors' powers of nomination

1. Report from the Select Committee on East India Patronage, 2 March 1809. See P.P.(H.C.), 1809, \# 91, Vol.2, pp.485-8.

2. H.M., Vol.398, pp.1-2. 
The most general use of patronage was almost certainly to establish a position in the Directorate or in Parliament. It is clear from the description of such an election as that of Toone, that in securing an entry into the Direction many obligations must have been incurred. Such obligations could most easily be met by a distribution of the patronage falling to the share of the new Director. The first letter written by the successful Sweny Toone to Hastings shows this clearly, and is worth quating in full:

"I am sorry to have it to say; that no Patronage will fall to my lot, before January next, \& then I am assured by Edward Parry, that the junior Directors will not have the appt. of a Bengal Writer. I wished to know from him, \& Mr.Bensley \& Darell, if it were possible in my situation to borrow a Bengal Writership. But they have assured me, which has been confirmed by the secretary, that they are filled up - Parry had borrowed an Appt. from Sir Francis Baring for Major Scott's son, not having to any Nomination himself to Bengal As these were few, they fell to the Lot of the senior Directors - What is to be done my dear Mr.Hastings - I am greatly mortified that Mrs.Hastings and you should be disappointed with respect to Henry Powney - But, I fear it is unavoidable - Be assured, I feel as much Mortification in not having in my power to obey your wishes, as Mrs.Hastings herself can feel. As to the Court doing it, Mr. Bensley says it is impossible - and Mr.Scott, who is just come 1 into the Direction is of the same opinion..." 1

1. Toone to Hastings, 13 April 1798. W.H.P., Addz.Mss. No. 29176, pp 28-9. 
Such uses of patronage to reward friends who had assisted a Director into office was nothing new. In 1765 George Francis Grand noted that his nomination to a cadetship by the Director Robert Jones was due, he believed, to his father having helped Jones to secure election to the Direction. ${ }^{1}$ It presumably continued for as long as elections were fought and patronage dispensed.

For those whose ambitions led them to lools beyond the Court of Directors to the House of Commons, patronage was again a valuable instrument, either in gaining or maintaining a seat in Parliament. From 1758 to 1800 there were one hundred and twenty-six persons who sat in the Direction. ${ }^{2}$ of this number thirty-four sat in the House of Commons during the period covered by the Parliamentary elections between 1761 and $1802,{ }^{3}$ and so enjoyed the privileges both of a Director and of a Member of Parliament. 4

1. George Francis Grand, The Narrative of the Life of a Gentleman Long Resident in India (edited by W.K.Firminger), p.Il.

2. C.M. \& D.Philips, op.cit., pp.327-336.

3. Return of the Members of the Parliament of Great Britain since 1761. P.P.(H.C.), 1878, Vol.62, Part $2(17,11)$, pp.1 $23-229$.

4. These Directors generally took up a strategic position by living in the vicinity of Russell Square, midway between Leadenhall street and Westminster. See Parkinson, op.cit., p.13. 
How useful a Director's patronage could be in managing a constituency can be seen from the examples of the Directors Robert Jones and David Scott. Jones had been in Parliament since $1758^{1}$ and entered the Direction in $1765 .^{2}$ In 1768 he can be found bolstering up his position in the borough of Huntingdon with his new patronage, by offering Lord Sandwich ${ }^{3}$ a Bengal writership for the latter's illegitimate son Robert Ray. ${ }^{4}$

In a like manner David Scott, a Director from $1788^{5}$ and M.P. for Forfarshire in Scotland from $1790,{ }^{6}$ made elaborate use of his patronage for Parliamentary purposes. In 1796 the Parliamentary constituency of David Scott consisted of the burghs of Forfar, Perth, Dundee, Cupar and st.Andrews. 7 In other words, these five burghs made the electoral district of Forfar which David Scott represented in Parliament. In the district.

1. P.P.(H.C.), 1878, Vol.62, Part 2(17,11) pp.113,127.

2. C.H. \& D.Philips, op.cit., p.331

3. Lord Bandwich was the patron of the borough of Huntingdon. See L.B.Namier, The Structure of Politics at the Accession of George III, p.146.

4. That Robert Ray was an illegitimate son of Lord Sandwich was stated by Grand, Ray's fellow passenger on board the Indiaman, Lord Camden in 1766 (see p.10) and has been accepted as true by Holzman (see p.43) and Parkinson (see p.16). In the birth certificate Ray's parents are, however, mentioned as "Richd.and Mary Ray". See W.P., Vol.6, 1765, No.52.

5. C.H. \& D.Philips, op.cit., p.334.

6. Return of the Members of the Parliament of Great Britain since 1761. See P.P.(H.C.), 1878, Vol.62, Part 2 (17,11), p.198. 
the town council of each burgh elected a delegate to represent the town at the election meeting held at the presiding burgh. These delegates elected the member of Parliament for the district, the delegate from the presiding burgh having the casting vote in case of a tie. ${ }^{1}$

At the beginning of 1796, the Provosts of the town councils of the burghs of Forfar, Dundee, Perth, Cupar and st.Andrews wrote to Scott stating their "hearty support" to him in the coming Parliamentary election. Scott replied to the Provosts of each burgh Forfar, ${ }^{2}$ Dundee, ${ }^{3}$ Perth, ${ }^{4}$ Cupar $^{5}$ and St.Andrews ${ }^{6}$ separately, reminding them of his past attachment to the burghs and promising to further their interests in future.

Immediately after his election to Parliament, he was pressed for a share in his Indian patronage by his

1. Furber, op.cit., pp.186-7.

2. Scott to Watt, 3 March 1796. H.M., Vol.728, p.313.

3. Scott to Thomas, 19 March 1796. Ibid., p.317.

4. Scott to Ramsay, 3 March 1796. Ibid., p.314.

5. Scott to Cheap, 3 March 1796. Ibid., pp.302-3.

6. Scott to the Provost of st. Andrew (name not mentioned), 3 March 1796, Ibid., pp.301-2. 
"Political Friends" 1 from all the burghs of his district. The Provosts of Forfar, ${ }^{2}$ Dundee, ${ }^{3}$ Perth, 4 Cupar $^{5}$ and St. Andrews ${ }^{6}$ all wrote to him for patronage and Scott tried his best to satisfy their demands. As the patronage at the disposal of a Director was limited, Scott found it necessary to borrow from his friends in the Direction ${ }^{7}$ and to maintain a "Book of Patronage" according to which he sought to bestow a writership or a cadetship on the soliciting candidates according to the seniority in the list. ${ }^{8}$ In a letter to Collins Salisbury, scott himself confesses his use of Indian patronage in maintaining his seat in Parliament:

"I ... have a just sense of your kind offices in my election, and if I had a Cadetship in my gift, you should have it immediately - When I left the Direction /out by rotation/ last year,

1. Scott to Duncan, $17 \mathrm{July} 1796$, H.M. Vol.728, p.463.

2. Scott to Watt, 8 August 1798, H.M.,Vol.729, p.221.

3. Scott to Riddoch, 7 February 1797, Ibid., p.41

4. Scott to Black, 25 January 1800, Ibid., p.402.

5. Scott to Rigg, 7 February 1797, Ibid., pp.40-1.

6. Scott to Duncan, 7 February 1797, Ibid.

7. Scott to Rigg, 9 April,1796, H.M.Vol.728,pp.334-5.

8. Scott to Rigg, 21 September 1800, H.M., Vol.730,p.175; Scott to Patton and others, 26 september 1801, Ibid., p.269; Scott to Montrose, 1 November 1801, Ibid.,p.288 Scott to Chisholme, 3 January, 1801 , Ibid., $\overline{\mathrm{p} .316}$. 
I was too much committed for patronage and the late Contest /of 17967 has increased exceedingly my obligations to my Friends - on my list of Cadets there are 11 not one of which can be struck off unless by themselves on finding my inability to serve them"l

The case of David Scott only illustrates with particular fullness what must have been a common practice by fellow Director-M.P.'s. The practice was, of course, no more than a special case of that use of the power to grant positions in the army and navy, the church and bench, customs and excise, royal household and colonial service which Namier has treated of so fully in his Structure of Politics at the Accession of George III. With all these other means of using patronage, the use of Indian appointments came under the ban in 1809, when by statute, 49 George III, C 118, it was declared to be an act of bribery for a Parliamentary candidate to promise an office or employment under the Crown to influence an election. ${ }^{2}$

The three personal uses of patronage considered above in advancing the interests of the Directors' immediate family, in rewarding those who had assisted him in his election and in gaining or holding a seat in

1. Scott to Salisbury, $17 \mathrm{July}, 1798 . \underline{\text { H.M. }}$, Vol.729, p.213.

2. Porritt, op.cit., Vol.1, pp.300-1. 
Parliament - do not by any means cover all the nominations conferred within our period. After 1773 there were after all only thirty-seven newcomers to the Direction, and between 1761 and 1802 only thirty-four nembers of the Direction held seats in Parliament. A full picture of the way in which the Directors made their choice of candidates for other purposes still remains to be mate. It can be assumed, however, that family friendships and connections, business associations and a desire to reward those who had served the Company by favour to their children and relatives must have been important in the distribution of patronage. In 1766, Rennell commented "most of the Gentlemen that came out are either Relations of Directors or of those whom it is their interest to serve". 1 Interpreting the word "interest" broadly, that judgment must have remained fairly true until the end of our period.

The diverse ways in which Directors used their share of patronage in pursuit of personal ends cannot but suggest that they did not always serve the interests of the Company as well as they did their own. It is of interest therefore to see how far they observed

1. Rennell to Burrington, 30 August, 1766. H.M., Vol.765, p.159. 
the two formal requirements imposed upon them in their choice of candidates for writerships and cadetships that such candidates should be of a stated age and have a knowledge of commercial arithmetic and of bookkeeping.

There were no fixed age-limits for writers and the cadets until 1784. All candidates were recruited in the belief that they were upwards of sixteen years of age. ${ }^{1}$ The first attempt to fix age-limits was made in October 1770, when the Court of Directors asked the Committee of Correspondence to report on this matter. ${ }^{2}$ After two years the Committee delivered their report to the Court which resolves that after that year "no person be entertained a writer in the Company's service, who at the time of his Election shall not have completely attained the age of seventeen years, or, who shall then be more than twenty-five years old". 3 In July 1784 the Court revised this decision and resolved that "no Writer or Cadet shall be sent to India under fifteen or above eighteen years of age,

1. W.P., Vol.10, 1783, No.40; Joseph Price, The Saddle Put on the Right Horse, p.17.

2. C.B., Vol.79, p.211.

3. This resolution of the Court of Directors is enclosed after the writers' petitions for 1775 . See W.P., Vol.8. 
except such persons as Cadets who shall have actually have been one whole year in His Majesty's Service, and then not to exceed the age of twenty-five years". 1 This resolution was valid for the subsequent nine years when it gave way to Sec.60 of Act 33 Geo.III Cap.211 of 1793. It was then enacted that "no Person shall be capable of acting or being appointed or sent to India, in the capacity of Writer or Cadet whose age shall be under fifteen years or shall exceed twenty-two years. $"{ }^{2}$

Before 1784, therefore, anyone who was supposedly over the age of sixteen was eligible for the services in India, and there are numerous examples of men being appointed to them in their late twenties, ${ }^{3}$ and even one who was in his fifties. ${ }^{4}$ The regulation of 1784 went to the other extreme and must have excluded many potential candidates until released in 1793 . The

1. Quoted in Danvers, op.cit., p.8; 24 Geo.III C25,Sec.43

2. Ibid., Blunt, op.cit., p.34.

3. For example, George Francis Grand was born in 1749, got a Bengal cadetship in 1766 and changed it for a Bengal Writership at the age of 27 in 1776 . See introduction (p.xvi) and p.57 in Grand, op.cit., Again, Charles Grant was born in 1746, became a cadet for Bengal in 1768 . He then returned to England and became a Bengal writer at the age of 26 in 1772. See pp.2, 14 and 28 in Henry Morris, op.cit.

4. See below p. 
regulations did serve two purposes, however, that of reducing the number of applicants to manageable proportions, and of recruiting young men of similar age who could be expected to adjust to the social and climatic environment in India nore readily than men of mature age.

To meet the educational requirements for the Company's service a certificate of proficiency in commercial arithmetic and book-keeping was required, and in the second half of the eighteenth century a number of boarding schools are found teaching these subjects. From the candidates' petitions the names of the most popular schools are to be found - in London at Broley-by-Bow, Bishopsgate, Chelsea, Chiswick, Chancery Lane, Fetter Lane, Kensington, Islington, Little Tower Street and Soho Square, and in Deptford and Greenwich, and outside it at Bath, Dublin and Edinburgh. ${ }^{1}$ Christ Church Hospital was one of the oldest mentioned, 2 and an academy at Finsbury square, formerly at Lothbury, whose advertisement appears in the Writers' Petitions records, perhaps the most famous. 3 The names of such public schools as Harrow, Eton and Westminster appear occasionally, but as they did not

1. W.P.,VoIs.3-17, 1757-1800.

2. Danvers, op.cit., p.6.

3. W.P., Vo1.14,1794. See after petition no.17. 
provide the required vocational training, boys from them had to engage the services of a commercial teacher. ${ }^{1}$ Thus Warren Hastings was taken from Westminster and put through a regular course of book-keeping by his uncle before he was sent out to Bengal as a writer. ${ }^{2}$

The candidate's proof of age was given by a certificate of baptism from the parish registrar and proof of the necessary educational attainments by a certificate from his commercial school or tutor. After 1784 where a baptismal certificate could not be produced it was necessary for the candidate to take an oath as to his age before a Mayor or Alderman or similar responsible official. 3 However, a close examination of the Writers' Petitions for the period 1757 to 1800 reveals that until 1784 both these conditions were very irregularly fulfilled. Thus in 1766, of the fiftyone writers selected for the Presidencies, sixteen could not produce the requisite certificates. 4 In the case of

1. For an example of a candidate for writership who had two educational certificates - one from a public school teacher and the other from a commercial tutor, see W.P.,Vol.16, 1798, no.13.

2. Foster, op.cit.,p.218. Also M.Ruthnaswamy, Some Influences that Made the British Administration in India, pp.15-6.

3. W.P., Vol.11, 1786, No.3.

W.P., Vol.6, 1766. At the end of the petitions for 1766 is enclosed a list of persons appointed writers for India who could not produce the requisite certificates 
the cadets no certificates of education can be found either in the Cadet Register or in the Cadet Papers while age certificates were first demanded in $1788 .^{1}$ and only appear in the Cadet Papers after that date. Yet there is no evidence to suggest that any candidate was ever rejected simply because he failed to produce his certificates of age and education. Samuel Martin, Secretary to the Treasury under Lord Bute and a probable connection of a former Director, Mathew Martin, of the East India Company in the twonties and thirties, could write to the Director George Amyard in 1764:

"I am a good deal troubled to find that the East India Company's rules require 2 certificates in a candidate for a Writership in their service, neither of which can possibly be procured in. relation to my brother Byam Martin ... If Mr. Rouse \& Mr.Crab Boulton \& the rest of the Directors are so good as to accept of my testimony on both these points instead of the ordinary certificates, I shall be relieved from a great distress. Otherwise my brother's fortune must be marred, or at least much injured, for want of these forms." 3

He did not write in vain. In the case of the young Charles Metcalfe, son of a Director, and later GovernorGeneral, the lack of an appropriate education was brushed aside with a more confident disregard of

1. C.R., Vol.1, p.150

2. Holzman, op.cit., p.153.

3. Martin to Amyard, 2 October 1764. Letter enclosed with petition No.13 in W.P., Vol.5, 1764 . 
regulations. William Hexten, his master at Eton, where book-keeping and commercial arithmetic were most certainly not taught, provided a certificate with the following accompanying note,

"As you allow this certificate you require which is on the other leaf of this sheet is not a matter of conscience but of office, I hope it will be sufficient for the intended purpose."1

The son of the Director duly received his appointment. Collectively the Directors were responsible for the welfare of the Company, and to that end they insisted that candidates should fulfil certain minimum requirements when seeking appointments under the Company. Individually, it is clear the Directors were ready to ignore such regulations and place first their own interest and those of their nominees. Their morality was the easy one of the age, and if they chose to provide for their dependents and benefactors at the expense of the Company regulations they were scarcely to be blamed.

Finally, it must be asked from what class of men did the Directors, in exercise of their patronage, chose the Company's servants in India. The Directors them-

I. Hexten to Metcalfe, 14 April 1800. Letter enclosed with the certificate of education for petition no.31. W.P., Vo1.17, 1800 . 
selves were businessmen, mexchants or bankers, or professional men, or members of the gentry. They selected candidates almost of necessity from among their own kind. There were still no large impersonal firms, departments of state, cities, and no organised means of public recruitment and examination in England. Applications for nominations came along existing social channels - from associates in the City or the shipping world, from members of a web of family ties and hierarchies in the country side, through services whose esprit de corps was steadily growing. Those who were members of the Court of Directors were upper middle class - those they selected were also middle class. Indeed only men of this class were likely to be able to find two sureties for $£ 500$ a piece or be able to pay for outfitting themselves for India and for their passage out, which by present standards was very costly. That the official section of the British Society in Bengal between 1757 and 1800 was predominantly middle class has been suggested by such studies as those of Kaye, Holzman and Wỏodruff (Mason), but it can also be sampled and demonstrated. A direct analysis of the social background of the writers and cadets recruited for Bengal in 1768, in 1780 and 1800 can be 
made though the determination of the occupation of fathers or nearest relatives of sixty-four writers and three hundred and forty-two cadets was difficult and in some cases impossible. The number of undetermined cases is particularly high for cadets since it is only after 1788 that their birth certificates with the names and sometimes the occupation of the father appear. The result of the investigation can be tabulated as follows :

Table 1: Showing the social origin of writers and cadets

Social 1768

1780

1800

Classes Writers cadets writers cadets writers cadets

Upper: Landed aristocrats $\begin{array}{llll}- & \end{array}$ $6 \quad 3$ and_peers Middle:

Merchants, traders and 15 $15 \quad 20$ 209 47 19 81 professionals

Lower: Artisans and $\begin{array}{lll}- & 1\end{array}$ 1 craftsmen

Total $15 \quad 28$ 9 54 22 95

LSources: (1) W.P., Vol.6A, 1768; Ibid, Vol.9, 1780; Ibid., Vol.17, 1800. (2) D.B.,Vo1.4, 1768. (3) C.R.,Vo1.1, 1780; 
Ibid., Vol.3. 1800. (4) C.P., Vol.5, 1800. (5) Major V.C.P.Hodson, List of the Officers of the Bengal Army, (1758-1834), London, 1927, 46-7 Vols 1-4. (6) J. and Sir B. Eurke, Landed Gentry (edited by L.G.Pine) London 1952 and Peerage, Baronetage and Knightage (edited by P.Townend) London 1963. (7) C.E.Buckland (editor) Dictionary of Indian Biography, London, 1906.

Sidnee Lee and Leslie Stephen (editors), Dictionary of National Biography, London, 1885-1901, Vols.1-66.

(9) Holmes'\& Co. (editor), Bengal Obituary, London and Calcutta, 1851.7

The study of this table will largely corroborate what Captain Joseph Price has said regarding the social classes of the writers. After an observation of thirty years, ${ }^{1}$ he wrote in 1783 ,

"The Young men chosen for writers were formerly selected from the middle orders of the people, such as the sons of Directors of the Company, their military and marine officers, their old servants abroad, and of merchants and capital tradesmen connectedinwith the company at home; latterly numbers of writers have been taken from the higher orders of society, and some of them the sons of the nobility. ${ }^{2}$

From the material for 1768,1780 and 1800 it may seem that the flow of sons of the nobility into Bengal

1. Price, op.cit., p.2.

2. Ibid., pp.16-7. 
writerships which Price speaks of has been exaggerated by him. Younger sons making an army career seem to have regularly been found, but the instances of civil employment, though they are to be found, were rare. The first reference of the son of a peer going to Bengal in the civil service in order to retrieve the fortuhe of a family occurs in $1769 . .^{1}$ In that year, John Hadley D'Oyly, later sixth baronet of Shottishain in Norfolk, went out to repair the damage inflicted by generations of spendthrifts. ${ }^{2}$ Next, in 1772 , came Robert Lindsay, son of the Earl of Balcarres, ${ }^{3}$ and in 1783, just before Price made his observations, Charles Blunt, another peer who had run through his fortune, entered the service at the age of fifty-one. ${ }^{4}$ The three between them do not suggest a trend.

If nobility were rare recruits to the civil service, so were members of the lower orders. The fathers of cadets included fireworker, ${ }^{5}$ jailor, ${ }^{6}$ saddler, 7 gunner, 8

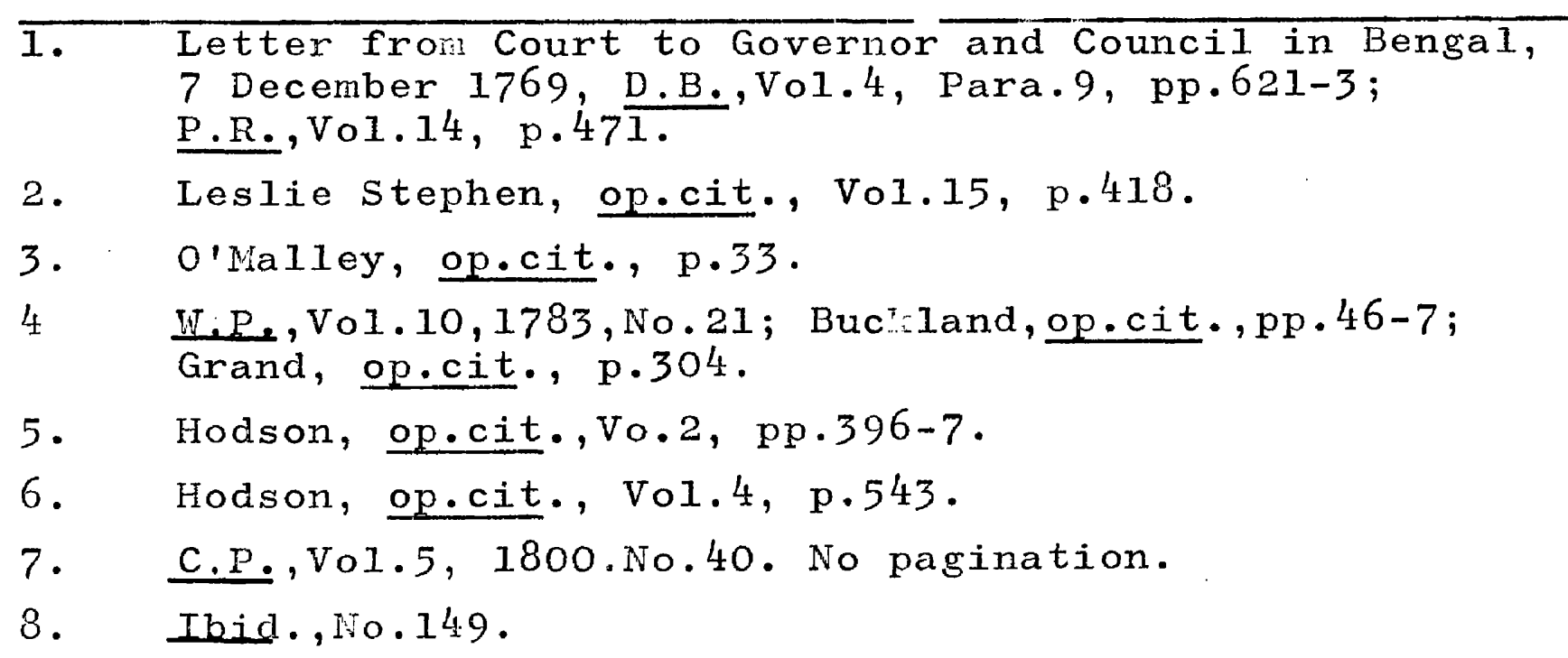


hairdresser, ${ }^{1}$ and miniature painters, ${ }^{2}$ but the evidence suggests that no such classes were ever represented in the Bengal civil service between 1757 and 1800 . Bernard S. Cohn's study of the Collectors and judges of Benares suggests that they were not represented in the following half-century either. ${ }^{3}$

Thus the writers and the Cadets recruited for Bengal between 1757 and 1800 had a similar class background. One factor which went to make this homogeneous community a closed one as against the natives of Bengal was the development of family connections within the services of the Company. The next chapter will attempt a detailed analysis of this social phenomenon.

1. Ibid., No. 237 .

2. Ibid., Nos. 206 and 460.

3. Cohn found of 75 collectors and judges the father's occupation was: Company services 16, landed gentry 24, merchants 19, professional 8, unknown 8. Cohn. Op.cil. p. 175 . 


\section{CHA PTER III}

THE DEVELOPMENT OF THE

BR ITISH OFFICIAL FAMIIIES

In the last chapter discussion turned upon the manner in which the Directors of the East India Company chose their servants for service in India, first when that Company had purely mercantile interests and then when it had become a territorial power, engaged in politics and administration. How they used their patronage depended upon their family, commercial and political connections and interests, and the distribution of that patronage served English means and ends. But the exercise of their patronage also had important consequences in India, for it was the type of men they selected, their education and their inter-relationships which decided the nature of British society in Bengal.

Who the young men selected for the Company's civil and military services were can be studied, In rather bare outline, in two series of records, one relating to writerships, the other to cadetships. For the former there are the volumes of writers' petitions in the India office Library, a series which opens in 1749. However, for certain Jears the sequence is broken: no lists survive for 1756 , 1767, and 1784 to 1789, while for many of the years between 
1749 and 1783 the lists which do survive are very incomplete. For example, though in 1768 thirty-three writers were recruit for Bengal, the petitions of only seventeen have survived. So though some hundreds of petitions have been consulted for the years 1750 to 1800 , it is only for the last eleven years, for which they are complete, that any statistical treatment can be attempted. For the cadets the material is even less satisfactory, for the Cadet Registers do not begin until 1775, and detailed records, comparable to the Writers' Petitions, only start from 1788 with the Cadet Papers. If one is concerned, as here, with Bengal only, there is a further difficulty in using the early records, in that before 1783 candidates for writerships did not state whether they were applying for posts in Bengal, Madras, Bombay or China. The candidate simply stated his qualifications in bookkeeping and commercial arithmetic and prayed for an appointment in the East Indies, while the Court of Directors, in granting his prayer, merely stated that a writership had been granted, without specifying the station. It seems

1. See Despatches to Bengal, Ilth November 1768, para 9 in D.B., vol. 4, pp. 143-5.

2. See W.P., vol. 6A, 1768 .

3. Ibid., vols. 12-7. Compare these volumes with volumes $1-4,7,8$ and 11 to note the incompleteness of the early volumes.

4. Compare the petitions in W.P., vols. 1-10 with those in vols. 11-17. 
that where the candidate was posted thereafter depended upon the nominating Director, and the appointments - to Bengal, Madras or Bombay - which happened to be at his disposal. It is presumably because of these practical difficulties that Dodwell and Miles did not begin their alphabetical Ilst of Bengal Civil Servants before 1780. For Bengal before 1780, the most convenient source is the list of Civil Servants going to Bengal, to be found in volume fourteen of the Personal Records series. Unfortunately though this provides a roll of all those despatched between 1762 and 1781, it offers little more than the bare names of the servants and the rank to which they had been appointed in Bengal.

For the earliest decades of the East India Company's existence in the seventeenth century we have ofn assessment of the men who directed, invested in and served the Compang in the recent study of K.N. Chaudhuri. This distingulshes two elements among the shareholders of the Company. One is the managerial group from whom the directors were recruited, conslsting of London merchants, closely associated with dealings in Indian commodities and

1. P.R., vol. 14, pp. 467-80.

2. K.N. Chaudhuri, op.cit. ch.IV. 
often interested in such other companies as the Levant or Russia Company. The other element is the wider body of investors who were not interested in management but in dividends and who included members of the aristocracy, the gentry, shopkeepers, widows and orphans and some foreign investors. It was the former group of city merchants who were responsible for the selection of servants for India. These latter had to be most carefully selected, with attention to their education and commercial experience, as well as to their "sufficiency", that is theị ability to provide substantial sureties for good behaviour. The directors, with their city connections, were well placed to undertake the recruitment of factors and writers for the East, so that control of patronage foll readily into their hands. In the latter half of the seventeenth century, the power of the city merchants in alliance with the Crown grew noticeably, and in years of high profits led to attempts by outsiders, from London, Bristol and other commercial centres, to break the control of Sir Josiah Child and open the East India trade to a much wider circle. The last years of the century thus saw a bitter struggle between the old and New Companies before the United Company emerged in 1709.

1. See also W.W. Hunter, op.c1t., vol.II, pp.143-51. 2. Supra., Ch.II. 
In the next fifty years, however, a stable directorate 1

appeared, still largely composed of merchants and of the shipowners who provided the vessels in which the Company's goods were carried, and closely linked with the government and with the financial institutions of Iondon. Despite the conflicts between factions within the Court of Directors and the intervention of government in the politics of the Company, the general pattern established in the first half of the eighteenth century continued in the second: of fifty-five directors who served between 1784 and 1800 between thirty and thirty-seven have been described as belonging to the city and shipping interests, only eighteen as having established their influence by service in India. The control by the Directors of the Company's commercial affairs, and of the recruitment of its personnel, in this whole period was rarely challenged by the shareholder or Court of Proprietors. The proprletors became an ever wider and more mixed body, thanks to the ready transferability of East India Company stock and the profitable security it offered, and it was rare for them to challenge the House Iist of proposed directors at the elections to the directorate. 3

1. Sutherland, op.c1t., pp.32-4.

2. Philips, op.cit, Appendix II.

3. Suthorian, opreit., ch. $\forall$. 
of the Company's servants in the second half of the seventeenth and first half of the eighteenth centuries little is known, for there have been no detailed study of them comparable to the studies of the Direction by Iucy Sutherland and C.H. Philips. The numbers of the Company's servants in the East grew with the growing trade, but the method by which they were selected did not greatly change, and presumably the merchant community of London, and families already connected with the Company's service continued, therefore to supply most of the recrults for Asla. There was, indeed, no obvious reason for change in the composition of the body of Company servants, for the prospects open to them, despite a ereater freedomfor private trade, did not change greatly before the 1750's. The service of the East India Company was secure and profitable, but not yet exciting in the way it became after Plassey. The pattern of recrultment before 1758 has been described as follows:

"The directors exercised in their appointments to their military and civil services and in their promotions within those services a great deal of patronage. Some of this certainly went to their own relatives and connexions, but much of it was used with the intention of obtaining or assuring the support of persons and interests within the Company. There seems to be little or no evidence of directors selling such offices for money, but every indication that the friends and relatives of those fevoured were expected to support the measures put forward by the directors in general and those favoured by their own patron in particular. 
Besides the Company's servants at home (relatively fer in number) and the relatives and friends of those serving abroad, there were a large number of others whose interests were connected with them. There were the leaders of the monied interest in the city who had a concern in the credit and smooth running of the Company; there were the City supporters of government whom the latter might urge to come to the directors' assistance; and there were all the numerous people who had trade connexions with the Company. There were the clothlers and Blackwell Hall factors, whose woollens the Company bought for export; the packers and dyers who prepared them; the private bankers and brokers through whom it obtained its silver bullion; the diamond merchants whom it licensed to export coral and bullion and to bring back in exchange precious stones either on their own behalf or as the agents of forelgn merchants. Finally, and most important of all because of their organization was the wellknown East India shipping interest." 1

It is not our purpose to study all the ramifications of patronage at home as well as overseas, and the period before 1757 is only of concern in so far as it serves as a base from which to measure change. However a study of the writers and cadets who went out in the early years of our period, before the full impact of the revolution in Bengal had made itself felt, can serve to illustrate the process indicated by Dr. Sutherland. Of direct patronage of their immediate relatives by the directors there is ample evidence. One example is Richard Barwell, Hastings' $s$ ally, for his family had boen connected with India for several generations, and his father

1. Sutherland, op.cit., pp.35-6. 
had been both a governor of Fort William and a director of the Company. William Raymond who went out as a writer in 1762, John Savage in 1764, William and Thomas Rooke in Raymond, Henry Savage and Giles Rooke respectively, and the William Wordsworth who went out in 1771 the descendant of Josias Wordaworth, who as a director between 1712 and 1739 occupied a chair for thirteen jears.

A Iink with the shipping interest seems to be provided by William Macket, ninth in Council and Military 5 Storekeeper in 1757, who was probably a relative of Captain William Macket, the Commender of the East Indiaman, the Prince of Wales. Another is provided by Andrew Wilson Hearsey, a Bengal cadet, sone of Andrew Hearsey, captain of an East Indiaman. For the Indian interest examples are numerous. Thus Robert Orme, the "Thueydides of Indian History" ${ }^{7}$ when he went out to Calcutta in 1742 joined an

1. See belor, p.

2. P.R., V0I. 14, pp.467-8.

3. C.H. and D. Philips, op.cit., pp.333-4.

4. Sutherland, op.cit., p.32.

5. B.C.S., vol. 1, p. 392 .

6. Holzman, op.c1t., p.40.

7. A. Wright and S.W. Lutley, Sterne's Eliza, p. 3. 
elder brother already serving in Bengal as a writer: both dobbtless secured their appointments in recognition of their father's services as a surgeon of the Company. John 3

Walsh, the paymaster to Clive's army in 1756, was a son of Joseph Walsh, governor of Fort St. George. William Frankland, seventh in Council and Buxey in 1757 was the son: of Henry Frankland, governor of Fort William in 1725. Mathew Collet, who became naval storekeeper and eighth in Council in the same year, had a number of Indian connections, among them a governor of Fort St. George. In like manner, Edward Stephenson who went out as a writer in 1762 had doubtless utilised his relationship with the Edward Steph10 enson who was governor of Fort william in 1728, while

1. Sidney Lee, op.cit., vol. 42, p. 256.

2. J.J. Higginbotham, editor, Men Whom India Has Knom, p.34

3. S.C. Hill, editor, Bengal in 1756-7, vol.1, p.cxxili.

4. Holzman, op.cit., p. 39 .

5. B.C.S., vol. 1, p. 392 .

6. Holzman, op.cit., p. 39.

7. B.C.S., vol. 1, p. 392 .

8. Holzman, op.cit., p. 40 .

9. P.R., vol. 14, p. 467 .

10. See Appendix II in BhaHacharya, op.cit., p. 227. 
1

Robert Palk who went out in $1770^{\circ}$ called upon his ties with Sir Robert Palk, gavernor of Fort St. George. It is clear that the tradition of family service in India, generation after generation, linking presidency with presidency and civil with military service was already well established by the opening of our period.

It is clear too that the Court of Directors were ready to acknowledge good service in the past as creating some obligation upon them in the present. Relatives often utilised the services of the deceased as a plea for appointments. Thus in 1758 James Morley petitioned the Court of Directors for a writership, supporting his claim with reference to the fact that "the Petitioner's Father served the Honble Company many Jears to an advanced station on the Bombay Establishment". 3 In 1762 Mrs. Elizabeth Rust asked that her son John Worthington Turner, who had gone out to India in 1754 as a free merchant, might be made "a Covenant servant on the Bengal Establishment", in view of the services of her late husband at Madras. Similarly in 1766 the mother of Roger Dumbleton prays for his appointment on the grounds that his father had lost his life in the service of the

1. B.C.S., vol. 2, p. 78.

2. Journal of the Calcutta Historical Society, 1909, vol.4, p. 496.

3. W.P., vol. 3, 1758, No. 23.

4. Ibid., vol. 4,1762 , No. 5. 
Company, and that her son was born in Bengal. The claim upon the Company was not always even as direct as this. Thus Henry Latham who put in a petition on December 1772 opened his case by stating that his father Captain Thomas Irthan had been the commander of His Majesty's shlp Tyger in the East Indies during the last Anglo-French war. - He had taken part in all the engagements against the French and had served in the squadron which supported Clive's recapture of Calcutta and selzure of Chandernagore in 1757, dying shortly afterwards. He then added,

"Your Petitioner hopes your Honors will be pleased, from a consideration of the Merit and services of his deceased Father, to appoint him a Writer on the Bengal Establishment; for which office, he
flatters himself he is duly Qualified." 2

It will be noted that though candidates for a writership were required to produce testimony as to age and qualificatio in book-keeping and commercial arithmetic, Iatham produced neither certificate of age nor training. He was content to "flatter himself that he was duly Qualified", produce a 3 testimonial from Pigot - presumably the ex-governor of Madras, $1755-1763^{4}$ - and rely upon the claims of his father's

1. W.P., Vol 6, 1766, No. 46 .

2. Ibld., vol. 7, 1772, No. 13.

3. Ibld., vol. 7, 1772, No. 13.

4. Buckland, op.cit., p. 336 . 
service. He was duly recommended by John Michie and offered a writership. We find however from the later petition of a brother Robert George Latham, that Henry had first been offered a Madras writership, which he had rejected as less profitable than the post in Bengal. In the end Henry Iatham did secure his Bengal writership and went out in 1773. A rather similar case, this time founded upon military service in the army, was that of John Durham, whose widowed mother applied for a writership for her son. Warren Hastings provided her with a testimonial: "The Father of this Young Man was formerly an officer in His Majesty's service and came a cadet to Bengal in 1772." ${ }^{4}$ In 1781 the young John Durham received his Bengal writer5 ship. Examples of such paternal care by the Directors for the sons and relatives of their servants, which had long been an established tradition, could be multiplied: the pleas of the orphan Henry Latham or the widows like Mrs Elizabeth Playdell ${ }^{6}$ or Mrs Wedderburn were regularly

1. W.P., vol. 7, 1772, No. 13.

2. Ibid., vol. 8, 1775, No. 28.

3. P.R., vol. 14, p. 474 .

4. W.P., vol. 9, 1780, No. 38.

5. P.R., vol. 14, p. 480 .

6. W.P., vol. 9, 1780, No. 10.

7. Ibid., 1781, No. 44. 
heard.

The great change in the Company's fortunes which occurred in Bengal in 1757, and which was confirmed in 1765 with the grant of the Diwani, had its effect, however, upon the attractiveness of the Company's service in Bengal. For some thirty years the prospect opened by a writership ceased to be the modest competence of the past and became a fortune. What then was the effect of this sudden inflation of the value of Bengal appointments? One answer is certainly an intensification of the use of patronage by the Directors in the immediate interest of their owm 2 families. It is not always possible, in the absence of baptismal certificates, to establish with certainty relationships between those appointed to Bengel in our period and members of the directorate. But to the names of Barwell, Raymond, Savage and Rooke already mentioned it would seem that in the twenty years 1762 to 1781 there may reasonably be added those of Thomas Browne and Charles Boddam, George Cuming, $H_{\theta n r y}$ Martin Creswicke, James Edward Colebrooke,

1. Mrs Playdell secured a writership for her son John Martin Playdeli, then a monthly writer in the Bengal Board of Trade in 1780, and Mrs Wedderburn, widow of the Master Attendant at Calcutta, a post for her relative in 1781. See E.R., vol. 14, p. 480 .

2. Supra, Ch. II. 
George Cheap, George Ducane, Jonathan Duncan, Charles Dempster, George Fletcher, Robert Gregory, Henry Hall, George Johnstone jr, Charles Hutchins on Purling, John Peach, William Bought on Rous, probably one or more Smith, Henry Vansittart, John Wombwell and Trevor Wheler! How many other cousins, nephews and more distant relatives ought to be added to the list it is impossible on the available evidence to say.

For the last eleven years of the century our information. is fuller, and we can list with more confidence those writers who owed their appointment to the fact that they were sons or nephews of directors. Thus in 1790 we have Thomas Baring, James Promrose Johnstone, James Money and possibly Watkin Williams Money, Richard Pattle and 7 Arthur Hastins Vansittart, in 1794 John Adam the nephew of the director W.F. Elphinstone and Henry John Darell, in 1798 James and Charles Patten, the nephews of the director

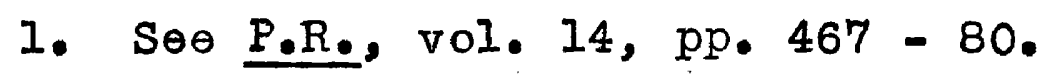

2. W.P., vol. 12, 1790, No. 10.

3. Ibid., No. 32 .

4. IbId., No. 51.

9. W.P., v01.14, 1794, No.21.

5. Ibid., No. 46.

6. Ibid., No. 58.

7. Ibid., No. 9.

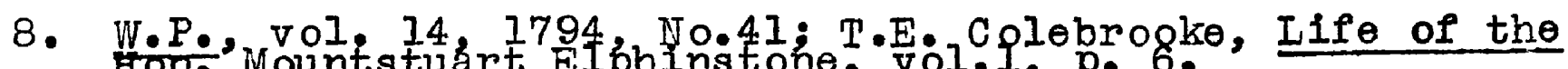


1

2

James Irwin, and Robert Vansittart and in 1800 John Ewer, 4 5

Charles Lushington, Charles Theophilus Metcalfe, George 6

Robarts and William Toome Swettenham, the nephew of Sweney 7

Toone. For the whole eleven years there are some thirty-

four sons or nephews of directors who recelved appointments

in Bengal - or just one in seven of all the writerships

given in those years. Doubtless this figure would be further

enlarged if more distant or concealed relationships were

disclosed. Even so whereas in the twenty years 1762 to

1781 some thirty-six sons or hephews may have been appointed to the civil service in Bengal, nearly as many, thirty-four that is, were appointed in the eleven years 1790 to 1800. The proportion of such appointments to total appointments had risen from one in twelve to one in seven.

One other feature of the pattern of patronage exercised within their own families by the directors follows from the fact that throughout our period and on into the nineteenth century, the proportion of directors who had served in India, as opposed to the city and shipping directors whose links with the Company were in London, was

1. W.P., vol. 16, 1798, No. 36 .

2. Ibide, No. 18.

3. W.P., vol. 17, 1800, No. 10.

4. Ibid., No. 27.

5. IbId., No. 31.

6. IbId., No. 1.

7. Ibid.. No. 17. 
steadily growing. Under a system of equally shared patronage therefore the prospects of families linked with India grew as the Indian interest in the Directorate grew. In practice, in the eleven jears 1790 to 1800 the Indian interest disposed of more than its fair share of Bengal appointments, eighteen Indian directors giving fourteen writerships, while thirty-one city and shipping directors gave only thirteen, this despite the fact that the chairs in the main were held by city or shipping directors. One can only assume that the latter made use of their power In contracts and in politics at home rather than by the dispensation of posts in India.

Once the family of a director had been installed in India it was very likely to prosper, for the support which could be drawn from home was very valuable while rules for promotion were still not systematised. Thus Jonathan Duncan, nephew of the director John Michie, when he went out to Bengal as a writer in 1772 made regular use of his uncle's position. Within a year Duncan had been appointed Dutch translator and socond assistant in the Sadar Diwani Adalat. When in 1781 he became acting Superintendent of

1. This information is based on a study of the Directors who recommended the writers for Bengal in the eleven years 1790 to 1800 . See W.P., vols. $12-7$ and Philips, op.cit., Appendix II. 
the Khalsa records he wrote to his uncle, and through him secured a recommendation from the court of Directors for his permanent promotion to that post. Again when in 1783 he found he was to be allowed less for his work as a Bengall translator than others received for Persian translation he at once appealed to Michie, and received a promise of an advance in his allowance. By 1783, after little more than ten years in India, Duncan was drawing some $£ 6,250$ a year In pay and allowances. In 1787 he was appointed, over heads of a number of men senior to himself, to the very lucrative position of Resident of Berares. Similarly Mountstuart Elphinstone, who owed his appointment in 1795 as a Bengal writer to his uncle, the director William Elphinstone, was warmly recommended by another uncle Keith, who had risen to high rank in the Royal Navy, to the GovernorGeneral Shore. It was thanks to the direct intervention of Shore that Mounstuart received a plum posting to Benaras. At a later date another good example of the value of a father in the directorate can be seen in the early career of Charles Metcalfe.

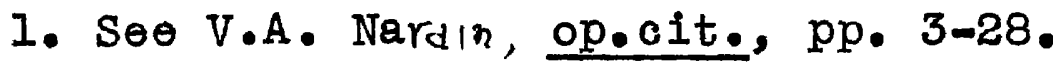
2. W.P., vol. 14, 1795, No. 44 . 3. Cohn, op.cit., p. 177 .

4. See J.W. Kaye's, The Iife and Correspondence of Charles, Lord Metcalfe. 
Moreover once one member of a family was well installed, it was probable that others would follow him out to Bengal to share his good fortune. Richard Barwell came out to India under the influence of his father william Barwell, one time governor of Fort william ${ }^{1}$ and a director until 1766. By 1773 he had risen to membership of the Supreme Council at Fort William, and his two brothers 4

Roger and Daniel Octavius had joined him. From 1799 yet another generation entered the Bengal service - Richard's four sons by his second wife, James Richard, Edward Richard, Charles Richard and Arthur Champion. In similar fashion

1. B.C.S., vol. 1, p. 276 .

2. C.H. and D. Philips, op.cit., p. 327.

3. P.R., vol. 14, p.475. Leslie Stephen, op.cit., vol. 3, p. 350 .

4. W.P., vol. 5, 1763, No.21.

5. B.C.S., vol. 2, p. 235, See also P.R., vol. 14, p. 473.

6. Barwell first married in Bengal in the $1770^{\prime} \mathrm{s}$ and had by his first wife two sons of whom the elder, Richard Barwell jr. died in 1800. Barwell married again in England in the $1780^{\prime} \mathrm{s}$ after his wife's death in Bengal. Sir Ioslie Stephen incorrectly states in the Dictionary of National Blography under Richard Barwell that his wife died inl778 leaving one son and overlooks his second marriage in England and the birth of four sons. See vol. 3, p. 350. For Barwell's two sons by his first wife, see B.B.M.B., vol, 2, p 287 (for Richard) and p. 291 (for Edward James) and for his second marriage and four sons, see Journal of the Calcutta Historical Society, 1934, vol. 47, p.76. 
Richard Becher, member of the Supreme Council in 1757 and 2 director in 1775, saw Edward Becher go out a writer in 1762, and two sons in the $1780^{\prime} \mathrm{s}$, followed by Charles Becher in 5 1795. John Prinsep who served in Bengal from 1771 to 1787 was followed by his two sons Henry Thoby and Augustus and by 182.9 no fewer than seven of the family were holding 6 positions in India. From George Colebrooke, director from 1767 to 1772, follow James Edward Colebrooke nominated writer in 1776 and Henry Thomas his brother, who came out 9 10 in 1782-83. The Grant clan, the family of Major John Scott, Warren Hastings's political agent", and the Elphinstones were other examples of the same trend.

1. B.C.S., vol. 1, p. 392 .

2. C.H. and D. Philips, op.cit., p. 327.

3. P.R., vol. 14, p. 467 .

4. W.P., vol. 9, 1780, No. 11 and Ibide, 1781, No. 23.

5. W.P., vol. 14, 1795, No. 19.

6. Dewar, op.cit., pp. 186-7.

7. C.H. and D.Philips, op.cit., p.328.

8. W.P., vol. 8, 1776, No. 23; also P.R., vol. 14, p. 476. 9. T.E. Colebrooke, The Life of Henry Thomas Colebrooke, p.4. 10. Embree, op.cit., p. 44. 11. I. and sir B. Burke, op.cil., p. 2266 , under Scott or Scott-Waring 
The two most astonishing, and well documented Bengal civilian families are however the Chicheley Plowdens and the Thackerays. The first of the Plowdens to serve in Bengal was Henry Chicheley. He was appointed cadet in 1773 but thanks to the influence of his brother-in-law, the director Edward Wheler, he was transferred to the olvil Service. He was followed by his brother Richard Chicheley Plowden who accompanied Wheler to Bengal and was appointed to the service in 1780. Yet an other Plowden, John Martin was appointed in 1781, and after Richard had returned to London with a fortune and entered the directorate in 1803, first four sons, and a nephew and then their various grandchildren secured posts in the Company's service. In the course of a century thirty-nine of the sixty-eight adult males were to serve in India, and sixteen of the forty-elght Plowden women married Company officers or officials. \&1

The history of the Thackerays is no less remarkable, and, thanks to the fame of the novelist, perhaps better known. William Makepeace Thackeray, the grandfather of the novelist, was the sixteenth and youngest child of

1. J. and $\sin$ B. Burke, op.cit., p. 2266, undor soott or Scott-Waring

1.8. Cohn, op.cit., pp.179-80. 
Dr. Thomas Thackeray, whose family had for some generations been settled at Hampsthwaite in the West Riding of York1 shire. William was born in 1749 and in 1764 he was sent to Bromley-bj-Bow to learn book-keeping and commercial arithmetic under a writing master named Sharpe. Once duly qualified he was nominated in 1765 to a Bengal writership, salling out with George FrancisGrand to Calcutta. His first posting was to the Secretary's office, but in 1768 he was appointed his Assistant Cash Keeper by Governor Cartier. On the strength of this useful promotion he brought his two sisters Henrietta and Jane out to Bengal. In 1771 he received a further very valuable promotion to the post of factor and fourth in Council at Dacca, under 8 James Harris as chief. In 1771 Harris married Henrietta and in the following year Jane was married to James Rennell

1. Sidney Iee, op.cite, vol. 56, pp.90-1.

2. W. P., vol. 6, 1765, No. 15.

3. Erand, op.cit., p. 6 .

4. B.C.S., vol. 2, p.6l.

5. B.C.S., vol. 2, p. 82 .

6. W. Hunter, The Thackerays in India and Some Calcutta Graves, p. T0.

7. B.t.s., vol. 3, p. 73.

8. Ibide, p. 108 .

9. B.B.M.B., vol. 2, p. 211 . 


\section{1}

the celebrated geographer of Bengal. In 1772 Thackeray becamecollector of Sylhet, and two years later third in 3

Council at Dacca. In 1775 he went to Calcutta and there fell in love with a talented, beautiful and most usefully connected girl, Amelia, the daughter of It. Col. Richmond 4

Webb, the second cousin of General John Richmond Webb. In 1776 Thackeray married Amel1a. He acquired as a brotherin-law Peter Moore, who had gone to Bengal as a writer in 1769. Thackeray may also have been connected by way of Amelia with the John Moore who went out in 1778, and with John and Jward Webb who were appointed Bengal writers in 9 10

1790 and 1795.

1. B.B.M.B., p. 220; Rennell to Burrington, 30 November 1772. H.M. vol. 765, p. 245. According to Hunter, the marriage of Jane and Rennell occurred first and from their new house at Dacca Henrietta and Harris were married. See pp. 81-2. This is a mistake. Probably Hunter has not seen the Marriage Register which recorded the ir marriages in Bengal.

2. B.C.S., vol. 2, p. 129.

3. Ibid., p. 170 .

4. Hunter, op.cit., p. 97.

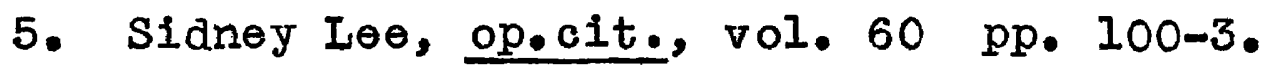

6. B.B.M.B., vol. 2, p. 261 .

7. W.P., vol. 6A, 1768, No. 23.

8. P.R., vol. 14, p. 477 .

9. W.P., vol. 12, 1790, No. 11.

10. W.P., vol. 14, 1795, No. 8. 
By 1777 Thackeray had amassed a sizeable fortune 1 by private trade in Sylhet and retired to England with his wife to settle close to his brother-in-law Peter Moore on a small property at Hadle ${ }_{3}^{2}$ By 1797 Thackeray had had twelve children by Amelia but happily his own Indian links and the city influence of his brother-in-law, who was elected M.P. for Coventry in 1803 helped to provide for them. Also of particular value was the friendship of Hugh Inglis, whom Thackeray had first met in Bengal at Governor Cartier's, and who now had entered the Court of Directors, of which between 1797 and 1812 he was three times Chairman. Inglis was mainly responsible for keeping open "the floodgates of patronage which so abundantly flowed from Leadenhall Street to the crowded household at Hadley Green. ${ }^{6}$

The eldest of Thackeray's sons, William, arrived in Madras as a writer in 1796 and died after twenty-seven 8 years of distinguished service there. The third son, Webb

1. See Ch. VIII "The Affair of the Elephants" in F.B.BradleyBirt, 'Sylhet' Thackeray, pp.177-215.

2. Hunter, op.cit., pp. 99-103.

3. Ibid., p. 105.

4. Sidney Lee, op.cit., vol. 38, p. 376.

5. Prinsep, e.elt., p.xiv; C.H. and D. Philips, op.cit., p. 33l.

6. Hunter, op.cit., p. 112.

7. W.P., vol. 14, 1796, No. 21.

8. Dodwell and Miles, editors, Alphabetical list of the Hon. East India Company's Madras Civil Servants, pp. 278-9. 
1

also went to Madras as a writer, as did the next son 2

St. John. The eighth son, Thomas went out as a cadet, but never rose above the rank of Lieutenant, while the joungest son, Charles practised at the Calcutta bar. Only one son, the Reverend Francis Thackeray did not go out to the East, but he married the daughter of a Bengal civilian, and their son Sir Edward Talbot Thackeray served the Government of India in the fifties and dixties of the nineteenth century. The remaining son was Richmond Thackeray, the father of the novelist. Richmond was born in 1781, privately educated by his father, and sent out as a writer to Bengal in 1797.

Richmond was to repeat the history of his father, William. In 1802 he went from Fort William College to his

1. W.P., vol. 19, 1806, No.9.

2. F.C. Danviers et al, op.cit., p. 476 .

3. Dodwell and Miles, editors, Alphabetical List of the Officers of the Indian Army, pp. 256-7.

4. Hunter, op.cit., p. 113.

5. Journal of the Calcutta Historical Society, 1910, vol. 6 ,

6. Buckland, op.cit., p. 419.

7. W.P., vol. 15, 1797, No. 5. Richmond studied at Eton but as Eton did not teach book-keөping and commercial arithmetic he had to learn these subjects from his father. See the letter of his father enclosed with the petition. 
1

first appointment at Dacca and there made a home for his two sisters, Emily and Augusta. In 1803, Emily married a young civilian John Talbot Shakespeare, son of John Shakespeare, the chief at Dacca in 1778, whose daughter Richmond's brother married. Of the nine children of Emily Shakespeare, eight either entered or married into the services of the 5

Company. Richmond's other sister, Augusta, married the Bengal civilian, John Elliot in 1816 and so established links with another large family clan.

Richmond himself after three years as Secretary 7 to the Board of Revenue married in 1810 one of the reigning beauties of the day, Anne Becher, daughter of John Harman

1. P.R., vol. 12, p. 614 .

2. Hunter, op.cit., p. 146.

3. B.B.M.B., vol. 6, p. 210 .

4. Journal of the Calcutta Historical Society, 1910,

5. Hunter, op.cit., p. 147. Sir Richmond Campbell Shakespeare who "faithfully and devotedly served the Government of India" was their youngest son and immortalised by the novelist in Lett's Diary, one of the Roundabout Papers. See Journal of the Calcutta Historical Society, 1910, vol. 6, pp.133-4, 298; Sidney lee, op.cit., vol. 5I, pp. 346-8.

6. B.B.M.B., vol. 10, p. 28.

7. Dodwell and Miles, editors, Alphabetical List of the Honourable East India Company's Bengal Civil Servants, pp. $504-5$. 
Becher, a Bengal civilian and a kinsman of Richard Becher. In 1811 William Makepeace Thackeray, the future novelist was born. Before the year was out his father died at the early age of thirty. His mother later married Major Henry Carmichael Smyth, of the Bengal Engineers.

\section{Unlike the Plowdens and the Thackerays, the}

Hearseys are an example of a typical family all of whose adult male members looked upon the Bengal Army as their right opening. Andrew Hearsey, the Captain of an East Indiaman and the brother of Theophilus, an influential Iondon merchant, died in 1778 leaving one daughter and one son Andrew Wilson Hearsey who had obtained a cadetship, on the Bengal establishment in 1765. Andrew Wilson died after many years of active military service at Allahabad in July 1798, leaving three daughters of whom the first two Charlotte

1. Hunter, op.cit., p. 160. The registration of the marriage of Richmond is missing in the record of B.B.M.B. vol.

2. Hunter, op.cit., p. 169.

3. Holmes and Co., op.cit., p. 203. At the time of his death Richmond was a Collector of the Ftwenty-four Pergunnahs. See R.C. Sterndale, An Historical Account of the Calcutta Collectorate, p. 24 and P.R., vol. 7 , p. 549 .

4. P.A.Burke, editor, Family Records, p.593.

5. Col. Hugh Pearse, The Hearseys, p. 2 .

6. Ibid., pp. 36-7. 
and Marion in the first decade of the nineteenth century married Paris Bradshaw an William Broome Salmon respectively both officers in the Bengal Army - and Andrew also left $a$ son John Bennet Hearsey. It was through the influence of his brother-in-law Paris Bradshaw, who "became connected with one of the East India Directors, Mr. C. C-," that John Hearsey was awarded in 1806 a civil ppointment in the Bengal Presidency. But as his widowed mother could not afford the expenses of his training at Haileybury, he was obliged to decline the appointment in favour of a cadetship for Bengal from the same Director. In the course of the next fifty years or so all six sons of John Hearsey by his two marriages entered into the Bengal Army and each of his two daughters married into the Indian services - one in the navy and the other in the army.

Membership of or some close link with a Director's family was thus one obvious way into the Bengal service. But it was not the only way of securing an appointment and rapid promotion thereafter. As the role of the governor and

1. See Hodson, op.cit., vol. I, pp.197-8 and col. 4, p.7.

2. Autoblography of Sir John Hearsey in Pearse, op.cit., p. 123.

3. Ibid., p. 405 et seq. 
council of Fort William changed from the supervision of commercial transactions to the administration of an empire, so did their importance and their ability to command patronage. True there was no direct allotment of patronage, but the links of governors and councillors with important groups within the directorate, and with the ministry of the day, and the wealth which many came to command, made them figures of such importance that their requests were not likely to go unheoded. The transference of Samuel Turner, a very near relation of Hastings, wade in 1780 on Warren Hastings's recommendation. It was again on Hastings's recommendation that in 1790 Julius Imhoff, the son of Mrs Hastings by her former husband Baron Imhoff, was granted a Bengal writership. of the other members of the supreme Council in 1774, Barwoll as has been seen was to provide for four sons. In 1778 General clavering's brother secured an appointment for one of his relatives. In 1782 it was

I. W.P., v01. 9, 188I, No. 37.

2. For an account of the Imhoff family and its relation with Hastings see H. E. Busteed, Echoes from Old Calcutta, Appendix V, pp. 404-10.

3. W.P., vol. 12, 1790, No. 14.

4. See above, p.

5. W.P., VOI. 8, 1778, No. 9. 
Colonel Monson's brother who was petitioning the Court of Directors for a Bengal writership for his fifth son, Thomas Monson, recalling "the many proofs he [Colonel Mons on] had given to prombte the honour and interest of the East India Company." I Philip Francis, for his part, brought his bro ther-In-law Alexander Mackrabie with him to Bengal, and on arrival secured for him the post of Sheriff of Calcutta. Not content with this, Francis used his influence with the 3 director Fitzwilliam Barringt on to secure Mackrabie's appointment to a writership in 1775. On the death of Mackrabie, who had vainly gone to madras in search of health in 1777, Francis wrote to the Court of Directors on 22 November 1777, asking that his cousin Richard Tilghman might be given Mackrabie's vacant writership. (He had already been in correspondence with director Edward Wheler about

1. W.P., V01. 10, 1782, No. 17.

2. Mss. Eur. E 25, Francis Mss. K 68, pp. 58, 87. Also infra, Ch. V.

3. Francis also wrote to Wheler and Harrison on 21 November 1775 about Mackrabie. Soe Mss. Eur. E 15, Francis Mss. K 49, pp. 257-259.

4. P.R., vol. 14, p. 476 .

5. Francis to Barrington, 19 January 1777. Mss Eur. E 15 p. 464. Also infra, Ch VI.

6. W.P., vol. 8,1780 , No. 10. This was not a usual petition, but a letter addressed to the Court of Directors on 22 November 1877. 
this "near relation and particular friend of mine", in $\left.1775^{1}\right)$ Tilghman was duly appointed, though in 1780 he resigned the service and accompanied Francis to England. In similar fashion the two sons, Hastings and Edward, of Sir Elijah Impey the first chlef justice of Bengal received writerships in Bengal in 1799 , and $1801^{6}$ respectively. Hastings's successor Lord Cornwallis is to be found nominating Alexander Ross to a writership in 1795, while Sir John Shore saw his cousin, Augustus Cleveland, who had followed him out to Bengal as a writer in $1771^{8}$, rise to be collector and judge of the diwanl adalat of the districts of Bhagalpur, Monghyr and Rajmahal, his nephew James Cornish become a judge in Bengal, and his great-nephew, Hubert

1. Francis to Wheler, 25 March 1775. Mss. Eur. E. 25, p.73.

2. See P.R., vol. 14, p. 478 .

3. Ibid., vol. 13, p. 567.

4. See B.N. Pandey, Sir Elijah Impey in India unpublished Ph.D. thesis, London 1958, and also E.B. Impey, Memoirs of Sir Elijah Impey.

5. W.P., vol. 16, 1799, No. 21.

6. W.P., vol. 17, 1801, iNo. 9.

7. Ibid., vol. 14, 1795, No. 43.

8. P.R., vol. 14, p. 472 .

9. See Ch. IV in F.B. Bradley-Birt, The Story of an Indian Upland, pp. 78-112.

10. Buckland, op.cit., pp. 84-5. 
1

Cornish arrive as a writer in 1795. Shore after his retirement from the office of Governor-General sent two sons to Bengal in the Company's service, one in the civil, 3 the other in the military line. Iord Wellesley, as is well known, had his two brothers Arthur and Henry with him in India in high positions. At a somewhat lower level we may note the presence in the Bengal civil service of the brother 6 and two sons of Randolph Marriot, the chief at Benaras, and the brother ${ }^{8}$ and two sons of Ewan Law, chief at Patna. ${ }^{9}$ on the military side there are John and Richard, the sons of Colonel Arthur Ahmuty of the East India Company's service, who receive writerships in $1790^{11}$ and $1791^{12}$, and David, the son of Major David Morries on who received his writership in

1. W.P., vol. 14, 1795, No. 34.

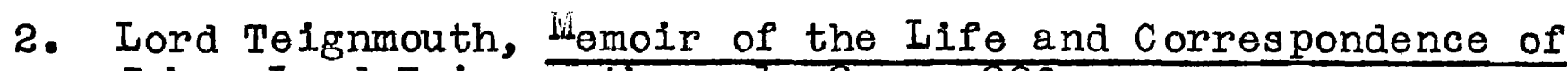
John, Lord Teignmouth, vol. 2, p. 296.

3. Ibid., pp. 346-7.

4. P.E. Roberts, India Under Wellesley, pp. 2-3.

5. B.C.S., vol. 2, p. 38; W.P., vol. 5, 1763, No. 15.

6. Holzman, op.cit., p. 42 .

7. B.C.S., vol. 2, p. 31 .

8. W.P., vol, 7, 1772, see the page next to the petition no. 13; P.R., vol. 14, p. 474 .

9. W.P., vol. 25, 1812, No. 2 and Ibid., vol. 27, 1814, No.37

10. B.C.S., vol. 2, p.312. In 1780 Ewan Law retired to England on account of his ill-health. See P.R., vol.13,pp.

11. W.P., vol.12, 1790, No.12, (12, Ibid,.,1791, No, 3. 
1

1799. Conversely one may find the example of Buswick Harwood entering into the military service as a surgeon while his brother William had been in the civil service since 1763 . One may also note the examples of families like the Hearseys all of whose male members entered into the military service of the Company.

A further group added to the members of the Bengal services, and in this case not necessarily linked either with the Court of Directors or with the ranks of the Company's servants in India was provided by the politicians. Even at the beginning of our period there were already established links between the Company and Parliament - a handful of directors were M.P.s, interested in contracts and other ministerial rewards, a number of M.P.s were large holders of India stock, and the government was always ready to utilise the Company's patronage, which included many minor positions in England, as well as offiees in India, in order to enlarge its own. In the sixties and seventies, the links became

1. W.P., vol. 16, 1799, No. 16.

2. Buckland, op.cit., p. 407. Harwood on his return to England studied medicine and became a Professor of Anatomy at Cambridge in 1785. See Leslie Stephen and Sidney lee, op.cit., vol. 25, pp. 101-2.

3. W.P., vol. 4, 1762, No. 16; B.C.S., vol. 2, p. 37. 
very much closer, as Indian affairs became a major political issue, and as successive ministries and the leaders of the opposition groups intervened by the purchase of India stock and use of patronage in the elections to the Court of Directors. The Company, for its part, played an increasingly significant role in Parliament, for as C.H. Philips has shown by 1784 there were sixty M.P.s with East India Company interests, and in 1806 as many as one hundred and three. The ramifications of itical interest in the exercise of the Directors' patronage in India it is not intended to pursue here in detail, but a few examples may suffice to show its influence. The appointment of Henry Clive, the son of George Clive, M.P., to a Bengal writership in 1799 might be thought of either as a Company or a political affair, but the writerships to Richard Gosling in $1768^{3}$ and to G.R. Foley in 1769 seem more certainly linked with politics, since the banking firms of Gosling and Foley were both employed in the stock splitting campaigns for the elections 5 of 1763 and 1765. The writership to John Macpherson, the

1. See Sutherland, op.cit., pp. 138-239.

2. W.P., vol. 16, 1799, No. 29.

3. $\log$ P.R., vol. 14, p. 470.

4. Ibid., p. 471 .

5. See Sutherland, op.cit., pp. 10-137. 
cousin of James MacPherson the government pampleteer, given in 1770 was clearly political, and he went out with a letter of introduction to Warren Hastings from Iord Shelburne. The appointments of the Hon. Frederick Stuart, son of Iord Bute, and of Elexander Elliot, the sone of Sir Gilbert Elliot, the King's friend, were again political - both men were pressed upon the Company by Iord North. George Oswald, 3

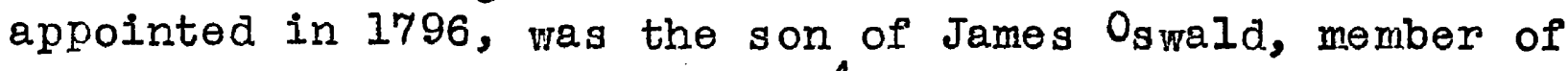
North's treasury board in 1762: he received his nomination to a writership from Dundas. Lauchlin Macleane was another political appointment, ant M.P., and supporter of Shelburne, who lost heavily in the great stock splitting campaign of 1772 in support of Sulivan, and who was sent out to Bengal to retrleve his shattered fortune. Further, after 1784 political appointments were more directly provided for by the allotment of a share in the Court of Directors' patronage to the Prime Minister and to the President of the Board of Control. Between 1790 and 1800 there were thus seventeen

I. Ibid., p. 300 .

2. Sutherland, op.cit., p. 299.

3. W.P., vol. 15, 1796, No. 45.

4. Steven Watson, The Reign of George III, 1760-1815, p.79.

5. Sutherland, op.cit., p. 299.

6. Supra, Ch. II. 
appointments to Bengal writerships given by william Pitt 1 and Dundas. There may have been more for some of the appointments of these years do not specify who the proposer was, and one must wonder if the influence of Dundas is behind the appointment of Sir Alexander Seton of Barrow2 Ionness, of Robert Keith Dick, son of Sir Alexander Dick of Duddingston ${ }^{3}$ and of Sir Frederick Hamilton.

One result of the exercise of political influence in appointments to Bengal was further to accelerate the growth of the Scottish element in the service. At the beginning of our period a casual inspection of the names of the writers being posted to Bengal suggests that they were quite solidly English born. By the end of the period the Scottish interest in Bengal was very firmly established, with Dundas at the Board of Control and Hugh Inglis and David Scott occupying the chairs. As Embree has pointed out, instudying one of the most influential scots in the service, Gharles Grant, service with the Company was an

1. See the writers' petitions for Bengal between 1790 and 1800 .

2. W.P., Vol. 12, 1790, No. 45.

3. Ibid., vol. 13, 1792, No. 13.

4. Ibid., vol. 14, 1795, No. 41.

5. P.R., vol. 14, pp. 467-80. 
1

invaluable outlet for many Jacobites after 1745, and the well established, national educational system of Scotland provided the Company with "a supply of youngmen remarkably well-equipped to be clerks in its Indian factories." ${ }^{3}$ From the time of Bute onwards the Scottish interest of forty five M.P.s and sixteen peers was normally in support of the existing government and thus in hope of being able touse ministerial influence, upon the Company to serve their own and their constituencies' interests.

"The real use of the member of Parliament," writes Steven Watson, "was to get what he could for Scotland in a practical way from the rich English offices. ... the purpose was not to represent Scotland (which was very effectively done by the Kirk) but to run an employment agency for the benefit of her surplus men of talentand the $5^{\text {pre- }}$ servation of her great family connexions." 5

By 1782 Joseph Price was commentingthat in India "no man of any other nation can be served in a province where the chief is a Scot, whilst a sootgman is to be found. " with ten

1. Embree, op.cit., p. 21 .

2. For a detailed account see H.G. Graham, The Social Life of Scotland in the Eighteenth Century, pp.417-83.

3. Embree, op.c1t., p. 22 .

4. J. Steven Watson, op.cit., p. 70.

5. Steven Watson, ep.cit., pp. 281 and 282 .

6. Quoted in Embree, op.cit., p. 19. 
Scotsmen serving in the Direction betreen 1784 and $1802^{1}$, including men of such importance as David scott and Hugh Inglis, and with Dundas, the manager of Scottish patronage as President of the Board of Control the process of drafting Scotsmen to India could not but continue. In the three years 1784 to 1787 of seven directorships falling vacant Dundas secured three for Scotsmen - Fitzhugh, Moffat and Elphintone - while in the years 1790 to 1800 of the eleven writerships in his patronage, eight went to scots. In the same eleven years of the writerships given by Inglis and David Scott again eight out of eleven went to fellow countrymen.

The Scots, however, were still less than one in six of the writers appointed in the last eleven years of the period, but the sample of 1800 gives them just over a quarter of all cadetships. The Irish were a less important element, taking only one in twenty-four of the writerships $a^{\text {nd }}$ one in eight of the cadetships. Of their number only a very occasional name is truly Irish, evidently the great majority were members of the Anglo-Irish settler community. Welsh names occur quite regularly, but only two writers and three cadets are noted in the sample as being actually

1. Philips, op.cit., p. 36 .

2. Ibid., pp. 53-4.

37. This is based on a study of all the petitions for Bengal 
born in Wales. Of the English contingents very large numbers as might be expected, came from Iond on and the home counties, a third of the writers and a quarter of the cadets. Of the remaining third, both writers and cadets, no one county provided more than a tiny handful, with the Midlands scarcely represented, and the West Country, Norfolk and Suffolk producing rather more than the average. Of the candidates thus scattered in ones and twos across the counties, quite a proportion seem to be political appointments, while others represent outlying members of established Indian families, as for example 1 James Money, the son: of Captain William Money, appointed by the Director William Money, or Hubert Cornish, son of James Cornish, a judge in the Calcutta High Court. In addition, there were writers born in Antingua, Bermuda, Dominica, France, North Carolina and Iisbon. The total pattern is very similar to thet recorded by Bernard Cohn for the origin of the seventy-five collectors and judges

1. W.P., Vol.12, 1790, No.s1.

2. W.P., Vol. 14, 1795, No.34.

3. This is based on a study of all the Bengal writers from 1790 to 1800 and the cadets for Bengal in 1800. 


\begin{abstract}
who served in Benares between 1795 and $1850^{1}$, suggesting that there was no marked change in the decades following our period.
\end{abstract}

The one very marked contrast between writers and cadets is found in the numbers of those who were born in India. Of two hundred and thirty-eight writers recruited between 1790 and 1800 either twenty-eight or twenty-nine had been born in India, the great majority in the presidency of Fort William, while of the one hundred and twenty-six cadets for 1800 only four were Indian born. This strongly reinforces the impression received from other types of evidence that European marriages in India in our period were largely restricted to the civilians whose wealth and prospects made them much more desirable

1. Cohn, op.cit, p. 175. Also supra, Ch.II.

2. See footnote 3, p.106 and I. Bartholomew, editor, The Survey Gazetteer of the British Isles and Reference Atlas of Greater London as weII as J.B., BetheI, Editor, Webster's Geographical Dictionary. 
matches for English girls than the Company's military 1. officers.

Of the education of the cadets and writers going out to Bengal it is difficult to speak with much confidence, though the writers' petitions do state in

1. Rennell explained the situation in a letter to Mrs. Burrington in 1767:

"They the ladies] are so very mercenary in their choice of husbands that such a poor fellow as I am would be looked upon as Nobody. Love here very seldom links a pair together.... You must know that I have for upwards of 3 years erchanged my blue coat for a red one, and am now forsooth a Captain - some critics have been severe enough to charge the fair sex with having a particular Attachment to that colour; but if it holds good in England, 'tis quite different here, perhaps it is because that the Military Men are the poorest class of people."

(See Rennell to Mrs. Burrington, 10 March 1767. H.M., vol. 765, pp.170-1.)

Certainly Margaret Fowke, sister of Francis Fowke, who came out to Bengal in 1776 at the age of seventeen in search of a husband seems to have acted on Rennell's pattern. She soon received a proposal from a It. Smith, who seems to have won Margaret's heart. Nevertheless, he was rejected, mainly it would seem because of his poor financial prospects. "He is agreeable and rather lively in conversation, with a strong and solid understanding, he unites a great share of Imagination with, I am informed, a very deep knowledge in the Mathematics," Margaret writes, but adds, "With the approbation of my father and brother, I have declined Mr. S's proposal We are not certain with respect to his fortune, but imagine it is small." In 1787 Margaret Fowke fulfilled her mission, however, by marrying the weqlthy civilian, later created a baronet, John Benn.

(See Margaret Forke to ? John Walsh, No date. Mss. Eur. D 10, Fowke Mss. K 23, pp. 19-20.) 
most cases how or where the necessary educational qualic fications had been achieved. The difficulty is that from the Company's point of view the general education of applicants was assumed - what it required was a certificate of proficiency in book-keeping and commercial arithmetic. Most candidates therefore furnished the testimony of a tutor or of a boarding school specializing in such training, such as that in Iittle Tower Street, rather than of a normal school. Of the major public schools Rugby, Eton, Harrow and Winchester are mentioned, and such grammar schools as Ashford, Blackheath, Stafford and Uppingham, while Scottish candidates mention various Academies and work under the Professor of Oriental Languages at Edinburgh. Rather fewer Scottish than English candidates mention tutors, thanks no doubt to the more widely available schools system. One candidate records a training at Rotterdam, and one or two give service with a firm of merchants. The clearest impression, however, is of the class origin of the writers merchants, professional men and gentry, with rather more younger branches of the nobility in Scotland. The East

1. This is based on a study of the educational certificates of all writers for Bengal in the last eleven years of our period. One interesting educational entry is that for Charles Elliot, a candidate in 1798, who records that he was educated by the Rev. John Venn, at Clapham. See W.P., vol. 16, 1798, No.19. 
India Company's service was already what Sir John Kaye was to call it a "great Monarchy of the Middle Classes." I The homogeneity of this middle class body was increased by the service in India of extended families, and among the civilians, by their intermarriages. Daughters and sisters accompanying their fathers and brothers to Bengal found India an effective marriage market. Thus, to give a very few examples, Elizabeth Holwell, daughter of John Zephaniah Holvell, governor of Bengal in 1760, married the civilian Charles Playdell in $1759^{3}$ (who was followed in 1777 and 1781 by Charles Stafford and John Martin Playdel1). Charlotte Lushington by her marriage with Ralph Leycester, linked a family which included william Lushington, writer 6 in 1763, Henry Lushington, killed at Patna, Stephen Iushingtor the Director and his son Charles, writer in $1800^{9}$, with the

1. J.W. Kaye, Lives of Indian Officers, p. xii.

2. B.C.S., vol. I, pp. 424-5.

3. B.B.M.B., vol. 2, p. 49 .

4. P.R., vol. 14, p. 476.

5. See above.

6. P.R., vol. 14, p. 467.

7. Journal of the Calcutta Historical Society, vol. 4, 8. C.H. and D. Philips, op.cit., p. 331. 9. W.P., vol. 17, 1800, No. 27. 
Leycesters, and her son William in due course went out a 1

writer in 1790. Sarah Stonehouse daughter of the Rev. Sir James Stonehouse, who in 1767 married Gerorge Vansittart, brother of the Governor of Fort William was probably a connection of the Miss Iucla Stonehouse who married Robert 4

Palk, the son of the governor of Fort St. George. In 1776 Elizabeth Jane Sanderson, then a reigning beauty of Calcutta, the daughter of Robert Sanderson, a Company civilian and 6

Sheflff of Calcutta, married Richard Barwell. Susannah

Smith, the daughter of a Madras merchant, and widowed sisterin-law of General Richard Smith, married Charles Theophilus Metcalf $\theta$, and once again linked two familles with ramifying Indian connections. As has also been seen in the family histories of the Thackerays and Chicheley Plowdens the Iinks forged between Indian families were endlessly renewed, across Presidency and across service boundaries.

1. W.P., vol. 12, 1790, No. 49.

2. Journal of the Calcutta Historical Society, 1909, vol. 3,

3. Ibid., 1909, vol. 4, p. 493.

4. B.B.M.B., vol. 2, p. 195.

5. See above,

6. Journal of the Calcutta Historieal Society, 1909, vol. 4,

7. B.B.M.B., vol. 2, p. 261.

8. Kaye, op.cit., pp. 3-4; Edward Thomps on, The Life of Charles, Lord Metcalfe, p. 6 .

9. B.B.M.B., vol. 2, p. 434 . 
The result of this development was that there was built up a circle of families whose links at home extended over the whole of the British Isles. The marriage which in England would have been arranged within known and limited circles, both territorial and to some extent professional, in Bengal resulted from a much more chance acquaintance within the orbit of the Company's service. These marriages gave to the lives of the British men and women who contracted them a focus in Bengal, and on retirement, in Ieadenhall street, which was quite new. Thus the Yorkshire Thackerays were linked in marriage with the Irish Rennell and the city merchant Moore and by friendship with the Scottish director Hugh Inglis - and it was the service of the Company which tied their lives together. Cross marriages also served to link the civilian and military services of the Company and so prevented any serious cleavage between them. The process of intermarriage was retarded in our period because of the habit of contracting liaisons with Indian women, forced upon all but the most senior of the army officers and the middle and upper ranks 1 of the civil service, but it operated with increasing effectiveness as the eighteenth century drew to a close. 
With the building up of families with a long tradition of service in India, often linked by marriage with one m other and with the Indian interest in the Directorate and Parliament, a career in India came to be looked upon as a firm expectation, almost as a right.

The development of such Iinked and extended British families in Bengal contributed to the making of a community which was closed against Indian soclety. As the anonymous author of the work, Observations on India, put it,

"Every youth who is able to maintain a wife marries. The conjugal pair, becaome a bundle of English prejudices and hate the country, the natives and everything belonging to them." 1

The ties between Company servants in India, the directorate and political parties also served in our period to shield and prolong the abuse of power. As early as 1773 Barwell was writing to Ralph Leycester, "that the servants abroad should interfere in the election of directors and solicit votes of their friends for the nomination of men under whose orders thej are to act becomes everyday more and more necessary." 2 The success of the Johnstone group and of the creditors of the Nawab of Arcot - as later of the Nizam

1. Quoted in Spear, op.cit., p. 141.

2. Quoted in Sutherland, op.cit., p. 214. 
of Hyderabad - was due to their ability to pull the strings which articulated the body politic of the Company. On the other hand once a measure of reform had been achieved under Cornwallis and Wellesley the close-kit quality of the Company's service helped to sustain a fair level of probity and of competence in administration in India, and to supply in the Court of Directors a body of expertise which no other system could easily have provided. Kaye summed up with a retrospective glance after the abolition of the Company in 1858 as follows:

"The 'nepotism of the East India Company' had its uses. It was said to be a monstrous thing that the services of the East India Company were, to a great extent hereditary services, and that whole families should be saddled upon India, generation after generation. We only discovered the good of this after we had lost it. That enthusiasm which is so often spoken of in these volumes as the essential element of success in India, was nourished greatly by these family traditions. The men who went out to India in those old days of the East India Company did not regard themselves merely as strangers and sojourners in the land. They looked to India as a Home, and to Indian service as a Career..." I 


\section{CHAPTER IV}

THE DEVELOPMENT OF THE ANGLO-INDIAN COMMUNITY

The place of kinship in the pattern of appointments to the Company's services in Bengal, and the appearance of such family dynasties as those of the Thackerays or the Chicheley-Plowdens, whose members linked together the army and civil service, with connections also in the Direction or in trade, has already been considered. The British community in Bengal had other kin, however, who deserve attention their children, born of Indian mothers, who formed the Anglo-Indian community. 1 The rapid growth in the number

1. Anglo-Indians were known as "half-castes" in the second half of the eighteenth century. The term was used disparagingly. The subsequent terms, "Indo-Britons", "East-Indians" and "Eurasians" were also disliked because they were applied, not only to the descendants of the British but also to those of the Portuguese, the French and the Dutch. In 1911 the Government of India first officially used the term "Anglo-Indians" ( see The Census of India, 1911, vol.1, Part 1, Para.202, p.140) but the definition of the term as given in the Census Report of 1931, Vol.1, Part 1, Para.180, pp.429-30, was not essentially different from that of the previous official term "Eurasians". 
of these descendants, "direct or indirect, legitimate or otherwise of European British subjects", 1 created a serious social problem for the East India Company. Because of their mixed origin they did not fit into either Indian or British society, and were despised by both. Their legal position in India was anomalous, and from the last decade of the eighteenth century they were excluded from the covenanted or sworn services of the Company. The creation of their community and the problems which it faced form the subject of this chapter.

All colonial regimes, whether Spanish or Portuguese, Mughal or British have created mixed communities in their country of settlement. But the manner of their creation, the social range involved, the attitudes displayed from positive encouragement to vigorous disapproval have been specific. It will be necessary, therefore, to consider the categories of persons in the Company's employment who married Indian women or kept them as mistresses, and the changing attitudes displayed towards the offspring of such unions in our period.

1. T.G.Clarke, The Fortunes of the Anglo-Indian Race, p.5. See also Whitley Stokes, The Anglo-Indian Codes, Vol.1, p.xi. 
Large bodies of men are unlikely to choose to remain celibate for any length of time, and in the eighteenth century the British who went to India expected to remain there for a considerable period of years, making their whole career in India. If they did not find European wives, it was to be expected that most of them would turn to Indian women for wives, mistresses or casual liaisons. The first question to be asked, then, is what whre the chances of a European marriage for the Bengal servants of the Company? The answer can be laboriously constructed from the lists of marriages contracted in Bengal which were sent to the Court of Directors each year by the government at Fort William. From these lists it is possible to show that at least 1,581 British and non-British Europeans married in Bengal in the years 1757 to $1800 ; 1,074$ of them at Calcutta, 507 at settlements outside it. The figures for up-country Bengal are not complete, for none were recorded before 1769 , from 1769 to 1786 , they are available only in one consolidated list, and only thereafter were annual lists compiled, as at Calcutta, for despatch to the Court of Directors. It may be that no marriages did take place outside Calcutta before 1769, but it seems more likely that the Registers were not 
maintained in the mofussil from which the lists were prepared for despatch to Iondon. In the latter case the total of marriages in Bengal during our period ought to be put rather higher, at about the 1,700 mark.

Of the 1,581 marriages for which details are available, a considerable number involve persons whose ocoupation and status cannot be determined from the records available. The remainder can be assigned, however, to the military service of the Company, officers, N.C.O.'s and European privates, and to the Company's European marine, to the civil and medical services, to the Ecclesiastical establishment, or to the mixed body of Europeans in Calcutta and the mofussil who were registered, but not in the Company's employ. 
Their numbers are as follows:

Table 3, showing marriages in Bengal during 1757-1800:

At Calcutta

(1757-1800)
At out-settlements (1769-1800)

Military Servants

(Army and Navy)

262

472

Civil Servants

148

9

Medical Servants

14

4

Chaplains

2

Outside the services of the Company

299

8

Undetermined cases

349

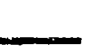

$\overline{1,074^{1}}$

$507^{2}$

1. B.B.M.B., Vol. 2, pp. 33,49,55,63,78,85,97,105,113, $131,151-2,156-7,163,182,195,211,220,223,235,249$, 261,273-81,351,420,433-4,455-6,467 covers 1755-1783; Vol. 4, pp. 7-9,11-2,27,35-6.51,83-4,101,123,137, 155,171,187,191 covers 1784-96; Vo1. 5. pp. 33-48, $121-36,213-26,313-29$ covers 1797-1800.

2. Ibid., pp. 339-340,481-2 covers 1769-85; Vol. 4, pp. $56,67-8,107,113,141,147,163,177,195$ covers $1786-96$; Vol. 5, pp. 49-58, 137-43,229-35,333-47 covers $1797-1800$. 
These categories cover a very wide range all ranks in the covenanted civil service; both officers and men in the army, both the King's and the Company's forces; captains, mates, sailors of East Indiamen, and the pilots in the service of the Bengal Presidency; surgeons, both army, naval and civilian'; and among those not in the service of the Company, free merchants, county shipmasters, mates and sailors, lawyers, carpenters, shopkeepers and tavern keepers. It is likely that many of those whose occupations cannot be determined belonged to the services of the Company. 2

1. Surgeons were attached not only to the army but also to the navy and the civil establishments. See H.M., Vol. 79, pp. 114-99; Vol. 362, p.181; B.C.S., Vols. I-2; D.G.Crawford, editor, Roll of the Indian Medical Service, 1615-1930, pp. XXXIX-XI.

2. The occupations of the bridegrooms are not always mentioned in the records. 
What proportion did those in each group who did marry bear to the size of the group as a whole? For some categories this too can be ascertained with a fair degree of completeness. Thus between 1757 and 1800 the number of writers receiving Bengal appointments was 756 , the number of cadets some 1,870 , or 2,626 in a11. 1 But the number of civilians of the covenanted service who married in this period was only 157, while of the military men who married, 262 in Calcutta and 472 up country, only 135 and 47 respectively were officers who had started their service as cadets. So while the combined number of writers and cadets going to Bengal in this period was 2,626, only 339 civil servants and officers got married, or approximately one in eight.

1. The sources from which this information is obtained are varied. For appointment of cadets in 1758-9 see B.D., Vol.1, pp.678, 780-1 and 929. For appointment of writers in 1760-1 and of cadets in 1760, see B.D., Vol.2, pp.180,373 and pp.150, 181. Major John Scott's manuscript list of civil and military servants in the Home Miscellaneous Series (Vol.79, pp.1-2) shows that 508 civil servants and approximately 1,200 military officers, i.e. cadets, got their appointments for Bengal during the period from 1762 to 1784. For appointments for the rest of the years from 1785 to 1800, Writers Petitions, Vols.11-7 and CadetRegister, Vols 1 (pp.77-9, 80-1,87-9, 91, 92-4, 97-109,113-6,118-26,136-48) and $3(\mathrm{pp} .10-21,27-58)$ are extremely useful. 
Even iff it is assumed that all the 339 bridegrooms came from these two groups, writers and cadets, the proportion marrying only reaches one in four. For the non-official Europeans living in Bengal, with or without the Company's license, the figures are much more imprecise. The practice of listing such persons only began in 1794,1 and the most useful list available is that of 1804. However, as this gives the place of residence, employment, native country, year of arrival and authority for residence in India, it is possible by eliminating those who had arrived after 1800 to establish how many were known to government to be in Bengal in 1800. The figures arrived at are 526 British and 53 non-British Europeans living in Calcutta and 360 British and 63 non-British Europeans living in the districts in that year, or about a thousand altogether. ${ }^{2}$ The number of non-officials had certainly been much smaller at the beginning of our period, for the total of Europeans in Bengal at the time of the fall of Calcutta in 1756 is given by Hill as 671. 3 How rapid the rate of turnover was for this non-official population

1. B.I.R.,Vol.34, Para 3. No pagination, 18 August 1794.

2. E.I.B,VoI.I, Item No. 5, No list no., no pagination. Sent home by the Lady Castlereagh on 13 November 1804.

3. S.C.Hill, editor, List of turopeans and others in Bengal in 1756 at the time of the siege of Calcutta, pp. 1-99. 
can only be a matter of conjecture. Even if it is assumed that the average stay in Bengal was ten years, some 3,500 non-official Europeans would have been in the marriage market there in our period. With 307 such persons known to have married in this period this gives only roughly one in eleven who did marry, or rather more taking account of the undetermined cases. The third group to be considered was those in the army. In 1757 there were about a thousand European troops of all ranks in Bengal, ten years later some three thousand five hundred, in 1784 perhaps four thousand and in Wellesley's day some five thousand. ${ }^{1}$ Since the Company's European troops were long service battalions, and the royal troops had very long spells in India, a conservative figure for the total number who saw some service in Bengal between 1757 and 1800 might be ten thousand men, but against this must be set the very heavy mortality experienced, as after Plassey, which required a constant flow of recruits and reinforcements to maintain battalions at strength, so that a possible upper limit of the troops who might have married would be two or three times as high. With

1. Lt.Col.P.R.Innes, The History of the Bengal European Regiment, p.278 et seq. 
only 734 marriages in the whole period from members of the army, the marriage rate can be seen to be very low indeed. To sum up, whereas one in four writers, and just possibly more, married, only one in ten of the cadets did so, and anything from one in fifteen to one in forty-five of the other ranks, and with a perbaps smaller range of error, one in eight of the non-official Europeans in Bengal.

The usual explanation for these very low marriage rates is that eighteenth century society in Bengal was predominantly masculine, that there were so few European women in Bengal that marriage for most men was impossible. From the available evidence it would certainly seem that the number of European women in Bengal in this period was very small. In 1756 when Siraj-ud-daula took Calcutta, while there were an estimated 671 European men in Bengal, there were only eighty European women, and in this figure many non-British names occur. ${ }^{1}$ In 1767 Rennell put their number at sixty in Dacca, ${ }^{2}$ and in 1810 Captain Williamson gives two hundred and fifty women for Bengal, "while the European male inhabitants

1. Hill, opicit., pp.1-99.

2. Rennell to Mrs.Burrington; 10 March 1767. H.M., Vo1.765, pp.170-1. 
of respectability, including military officers, may be taken at four thousand". 1 In 1813 the women were said to number approximately three hundred. 2 since numbers before 1800 had probably not been added to greatly during the dangerous years of the Revolutionary and Napoleonic wars, a figure of about two hundred British and other European women may have been present in Bengal at the end of our period, if the estimates of Williamson and D'Oyly were tolerably correct. This accords with Holden Furber's modern estimate that the total number of European women in Bengal did not exceed a few hundred at any time in the latter half of the eighteenth century. ${ }^{3}$ How few the ladies were can also be seen in the letters and journals of the day. The diary of Alexander Mackrabie gives a vivid picture of the inadequacy of their number:

"Evening. All at the Assembly. You never hear of our Dancing. No, we are past all that. Besides, the Ladies are generally engaged for two months. We have no chance." 4

Some days later the entry is even more despondent:

"Evening at the Assembly. Very little company. Judge Le Maistre has a large party at his House to commemorate his Wedding Day. What a plague is this to us, that we must lose our Ladies and our Music." 5

1. Capt.Thomas Williamson, The East India Vade Mecum, Vol.1, p.453.

2. Charles D'oyly, The Europeans in India, p.xx.

3. Holden Furber, John Company at Work, p.25.

4. 4 March 1774. See Mss.Eur.E.25, p.107.

5. 18 March 1774. Ibid., p.109. 
One can but pity the poor batchelor thus denied even the mild enjoyment of feminine company.

The picture would seem to be one of numbers of batchelors, officials and non-officials alike, anxious to marry but prevented by the small number of possible wives available. This is not unexpected. As the period advanced fewer and fewer persons entered the Company's service as men of a mature age, except in such posts as governor of a presidency, judge of the Supreme Court, captain or officer in the Company's marine, or commander of its armies. Few came to India as married men, and not all of these brought their wives with them. The cadet or writer who sailed for India at from fifteen to twanty years of age, obviously went out unmarried. But he had little prospect, either, of any early return to England, for there was no provision in the eighteenth century for regular furlough. It was necessary to resign from the service, giving up pay and position ${ }^{1}$ and any certainty of re-employment, ${ }^{2}$

1. B.D., Vol.9, Para 12, pp.149-50. Quoted in Ghosal, op.cit.,p.51. Furlough was granted to army officers only in 1796. Even then subalterns had to have served ten years before they were eligible. Borat, op.cit.,p.62.

2. Embree has noted the difficulty which Charles Grant experienced in securing re-employment in India after his return home in 1771. Embree, op.cit.,p.43. 
to make the expensive journey home in search of a wife. An opportunity to marry reasonably early in life would seem therefore to have depended on the number of girls coming out to India from Europe.

Almost each season did see consignments of fair maidens arriving in the Hooghly in search of husbands. For those unfortunate in Britain, India was seen as a last hope:

"Your sister /M̄argare $\bar{t}$ goes out now, I suppose, to get her a husband, which she has not beauty or fortune enough to get here",

wrote Francis Fowke to his nephew in Bengal. ${ }^{1}$ There was a proverb that the journey to Bengal was worth $£ 300$ a year in hushands, dead or alive, either in salary or in pension from the Civil Fund. ${ }^{2}$ And in the previous Chapter fathers and brothers have been shown bringing their daughters and sisters to Bengal in pursuit of such husbands. A search of the Marine Records of the Company has failed to reveal how many women came out each year to Bengal, for the journals of the captains

1. Francis Fowke, sr.to Francis Fowke,jr. 22 November 1775. Mss.Eur.E3, Fowke Mss.K20, p.76. Rennell gave more thar £400 as dowry to his sister for her marriage in England. Rennell to Burrington, 16 November 1767 and $20 \mathrm{July}$ 1769. H.M., Vol.765, pp.177 and 200.

2. W.H.Carey, editor, The Good Old Days of Honourable John Company, Vol.1, p.127. 
contain only navigational descriptions of the royage and the logbooks only the names of the crew. There are a number of references, however, in the court Books to applications from unmarried women applying to the Court of Directors for permission to go out to Bengal to reside with their friends. Usually the grounds for such applications are that they have no relatives to provide for them in England, but it does not seem unreasonable to assume that the ultimate object of such arduous and costly voyages - a passage and outfit would cost about $£ 500$ - was matrimony. The Court of Directors usually gave the desired permission, ${ }^{1}$ and on occasion even exempted the applicant from payment of the $\$ 12$ license fee. 2

Occasional references to the shipment of ladies to Bengal may also be found in the contemporary letters, memoirs, travels and newspapers. In 1765 Colonel Webb writes to his son, "L must now busy myself with putting your sister out". Lady Ritchie suggests, in the introduction to her father's Ballads and Miscellanies that "the putting out" of Col.Webb's daughters meant shipment to Bengal. 3 In 1777 William Hickey, at Portsmouth on

1. C.B., Vol.93, p.643.

2. Ibid., Vol.79, p.354.

3. Quoted in the Journal of the Calcutta Historical Society, 1915, Vol.10, p.163. 
his way out to practice in the Supreme Court at Calcutta, met the two Miss Bertis, sisters-in-law of Captain Arthur waiting to sail in the Indiaman Seahorse to Bengal in search of husbands. ${ }^{1}$ In another East Indiaman in July 1780 eleven ladies came out - "too great a number for the peace and good order of a Round House", as a correspondent of Hickyls: Bengal Gazette remarked. 2 In 1787 the Fowke's correspondence reveals Francis Fowke senior packing off Sophia Fowke, the natural daughter of Joseph Fowke, to the care of Francis Fowke junior in Bengal. Sophia had apparently been very unwilling at first, but finally agreed to the plan, writing to her uncle,

"As I look on my Fate at best to be a very poor one, India, even on the terms you represent it, situated as I am, I prefer to anything England will afford me; it is the only alternative and I will embrace it with joy, and if my Relatives will do their best to forward me I shall esteem myself eternally obliged to them." 3

1. Hickey, op.cit., Vol.2, p.101.

2. Quoted by J.W.Kaye in "The English in India - our social morality", in Calcutta Review, 1844, Vol.1,p.327

3. Sophia Fowke's letter was quoted by her uncle in his letter to his nephew, 4 Ootober 1787. Mss.Eur.E.7, Fowke Mss K28, p.209. 
Six years later, in 1793, the Thetis brought out to Calcutta Lady Shore, her thirteen year old daughter, the five unmarried daughters of Sir Charles Blunt and a similar number of General Brisco's daughters, "all very fine, showy and dashing women", 1 so Hickey commented. In the early nineteenth century women continued to make applications to the Court of Directors for "permission to try their fortune" in Bengal, ${ }^{2}$ and Thackeray in his famous novel Vanity Fair enshrines the practice in fiction with his account of "how Mrs.Hardyman had had out her thirteen sisters, daughters of a country curate, the Rev. Felix Rabbits, and married eleven of them, seven high up in the service". 3

As the supply of marriageable European women was so unequal to the number of batchelors in Bengal, official and non-official, it would be natural to expect that any who reached the presidency would be readily disposed of in marriage. There were some who became much courted and sought after, and who could choose their husbands from

1. Hickey, op.cit., Vo1.4, p.114.

2. George Hadley, A Compendious Grammar...of Hindostan, p. 47 .

3. W.M.Thackeray, Vanity Fair (edited by Geoffrey and Kathleen Tillotson), p.581. 
among the most senior members of the service. Thus Elizabeth Jane Sanderson, an accomplished girl, eventually married Richard Barwell, a member of Council since $1774 .^{1}$ Another much courted person was Emma Wrangham, described by Hickey as "a fine, dashing girl, not by any means a regular beauty, but an uncommonly elegant figure and person; remarkably clever and highly accomplished". 2 Her name frequently appears in the "Poets' Corner" of Hicky!s: Bengal Gazette. She finally married John Bristow, a civilian who had gathered a considerable fortune, 3 and rather a dark horse, since his name did not appear in Philip Francis's list of her suitors. ${ }^{4}$ But though such accomplished young women might pick and choose, many of the women who came out to Bengal found husbands difficult to find. On 21 November 1775, Francis writes from Calcutta to Lady Clive,

"Among other Calamities incident to the climate, would you believe that all the Beauty we brought with us has not produced a single Marriage. The Market, I presume, is overstocked, at least there are no Bidders at the public sales. I believe we must prohibit the farther Importation of spinsters, "till we have disposed of the stock on hand." 5

1. Supra, Ch.III, Also Grand, op.cit.,pp.37-8. Grand was one of the suitors.

2. Hickey, op.cit.,Vo1.3, p.377.

3. Philip Woodruff, The Men who Ruled India, Vol.1,pp.158-9

4. Francis to Livius, 14 January 1782.Mss.Eur.E. 19, Francis Mss.54 K54, p.32.

5. Francis to Lady Clive, 21 November 1775, Mss.Eur.E15, p. 264 
In the last decade of the eighteenth century the Rev. Tennant notices that a number of unfortunate females who had braved the sea for the purpose of getting married in Bengal were usually forced to abandon "the forlorn hope" and return to England after the loss of beauty in the alien climate. ${ }^{I}$ A lady who had actually witnessed this state of things, sought to impress upon a friend who wanted to try her luck in Bengal, "the folly, and impropriety of ... making such an attempt". ${ }^{2}$ A similar warning letter, in the Asiatic Journal, records the sad case of a highly accomplished lady who "after refusing several excellent offers from men of rank and fortune in England" went to reside with her relative in Bengal, but found herself after several years still unmarried, and finally determined to go back to England. 3

How did it come about, when wives from Europe seemed in such short supply, that any girl who braved the journey to Bengal failed to find a husband? The answer seems to be an economic one, that marriage with a

1. Rev.W.Tennant, Indian Recreations, Vol.1, p.79.

2. This letter was quoted by "N.S.B." in his correspondence to the editor of the Calcutta Gazette, 20 January 1820. See Hugh David Sándeman, editor, Selections from the Calcutta Gazettes, Vol.5, pp.326-31.

3. Letter to the editor, no date. See Asiatic Journal, London, 1816, Vol.2, pp.548-50. 
girl from Europe involved a husband in a large expenditure which few could afford. As the Dutch traveller, Stavorinus, writes in 1770:

"Domestic peace and tranquillity must be purchased by a shower of jewels, a wardrobe of the richest clothes, and a kingly parade of plate upon the sideboard; the husband must give all these, or, according to a vulgar phrase 'the house would be too hot to hold him', while the wife never pays the least attention to her domestic concerns, but suffers the whole to depend upon her servants or slaves." 1

European society in India was competitive in octentation and extravagance, as the Dutch and English tombs in Park street cemetery testify, and the result of competition among the married ladies, in dress and ornament, must often have fallen heavily upon the husbands who provided them. 2 Wives in India required dressmakers, hairdressers and ladies' maids, and since they did not perform their maternal duties, every child born required two or three servants to attend it. 3 Then when a child reached four or five years of age, he was sent to England, and the mother often accompanied

1. J.S.Stavorinus, Voyages to the East Indies, 1768-78, Vo1.1, p.523.

2. Rennel1 to Burrington, 1 słptember 1770. H.M., Vol.765, pp.206-7.

3. A Young Civilian in Bengal, 1805. Memoir of Henry Roberdau in the Journal of the Calcutta Historical Society, 1925, vo1.29, p.124. 
her infants because of her ill-health ${ }^{1}$ or to supervise their education in England. ${ }^{2}$ The lowest possible sum that could be expended on his wife by a husband in respectable circumstances would be approximately $£ 300$ a year, and on a child going to England another $\$ 150$ a time. 3 This would be in addition to the normal costs of maintaining a middle-class establishment - the enormous rent of a house, the wages of an establishment of servants, perhaps $£ 150$ upon each item, and the expenses of dress, table and carriage or palanquin. 4 Captain Williamson, in his The East India Vade Mecum relates that a batchelor would require at least $£ 600$ annually for a plain:style of living in Calcutta, without a garden house to which he could flock to escape the sultry weather, a carriage for his evening drive and frequent parties to entertain his friends. 5 This was very similar to the estimate made as early as 1770 by Stavorinus regarding the annual expenditure of "the least in rank" in the Company's service. 6

1. Williamson, op.cit.,Vol.1, p.456.

2. Mrs.Bristow, formerly Miss Emma Drangham, left her husband in Bengal and embarked for England in 1790 solely for "the proper education" of her four lovely children. See Hickey, op.cit., Vol.3, p.377.

3. Williamson, op.cit., Vol.1, p.456.

4. For the style of living, see Chapters $V$ and VI.

5. Williamson, op.cit.,pp.173-5.

6. Stavorinus, op.cit., Vol.1, p.523. Also infra, Ch.v. 
But to add $\$ 300$ for a wife, and further expenditure on children, to a basic yearly outlay of $\$ 600$ a year was far beyond the capacity of most of the Company's civil and military servants, except the most senior. Until 1758 the Court of Directors were paying their civil servants at the rates fixed by the Court Minute of $1674 .^{1}$ After 1758 the Court only increased the salary of governor from $£ 300$ to 22,700 , that of a member of Council from $£ 100$ to $£ 132.17 \mathrm{~s}$ and that of a writer from £5 to £27. It is true that some were able to acquire fortunes during the political revolutions after Plassey, and others by private trade, but their numbers were never large, for not all trade prospered. Again Clive's scheme of 1766 , whereby the proceeds of a salt monopoly were applied to increasing the salaries of the servants, would only have benefitted the more senior, even if it had not been disallowed by the Court of Directors in 1768. The Company did grant further increases in salaries in that year, the Governor of Bengal advanced to $£ 4,800$ a year, plus a commission on the revenues which

1. According to that Minute, writers received $£ 10$, factors $£ 20$, merchants $£ 30$ and senior merchants $£ 40$ per annum. See E.B.Sainsbury, editor, A Calendar of the Court Minutes etc. of the East India Company $1674-76$, pp.xxv-xxvi. 
brought his total remuneration to $\$ 23,000$ per annum, while members of Council drew from $£ 1,500$ to 3,000 according to rank, with commission in addition. But the writers' salaries only went up to $£ 50$ and those of senior merchants to $£ 81$ a year. ${ }^{1}$ The Regulating Act of 1773 similarly benefitted the centor members of the service, granting $£ 25,000$ a year to the GovernorGeneral, £10,000 to the members of his Council, £8,000 to the Chief Justice of the Supreme Court, and $£ 6,000$ to the Puisne judges, ${ }^{2}$ but the junior civil servants of the Company had to wait until 1793 for "a living wage". 3 By the Charter Act of that year civil servants might receive up to $£ 500$ a year after three years' service in India, £1,500 after six, £3,000 after nine and $£ 4,000$ after twelve years' service in India. 4 The military servants of the Company did even less well than the civilians, and only the pay of a Colonel and Letenant-Colonel were really adequate. After Clive's reorganisation of the army according

\footnotetext{
1. Blunt, op.cit., p.33.

2. Auber, op.cit., p.604.

3. Blunt, op.cit.,

4. 33 Geo.III C52, section 58, 37. See Auber, op.cit., pp. $637-8$.
} 
to the instructions of the Court of Directors in 1766 , while a Colonel and Lt.-Colonel drew sonaut Rs.1,550 and Rs.1,240 a month respectively - or roughly the same sum in pounds sterling a year - a Captain or Captainlieutenant drew Rs.372, a Lieutenant Rs.248, an Ensign Rs. 186, and a Cadet Rs.124, even including allowances. ${ }^{1}$ In 1796, when new pay scales were promulgated, the basic pay, including Tent allowances and half batta, were for all officers somewhat less than the figures given above for 1766, while in garrison, though more was received up country and in the field. ${ }^{2}$ Moreover, as the century progressed the rate of promotion in the Bengal Army grew slower and slower, so that a subaltern might often be detained in the same rank for more than twenty years before obtaining even a Lieutenancy. ${ }^{3}$ The reforms of 1796 were designed to expand promotion prospects, but even so there were over 140 Bengal subalterns of 14 or 15 years standing who had virtually no hope of promotion. 4 The miserable condition of the subaltern was given poetic expression in a famous ballad called "NinetyFive", in which were sung the woes and miseries of

1. Capt.A.Broome, History of the Rise and Progress of the Bengal Army, vol.1,pp.558-9. After 1773 the value of a sonant rupee was the same as that of a rupee. Usually a sicca rupee became sonant after three years in circulation. H.Yule and A.C.Burne11, Hobson-Jobson, p.775; Journal of the Calcutta Historical Society, 1925, Vol.30, p.232.

2. Barat, op.cit.,p.62.

3. Ibid.,pp.55-6.

4. Ibid.. p.71. 
existence on that many rupees a month. Its author, "Jacob Sorrowful", presumably a subaltern sent it in March 1787 for publication in the Calcutta Gazette, saying; "Go where I will, at any station of the army, Ninety-Five salutes my ear, and I verily believe there is not a small hero in the country but sings it delightfully." 1

It may be argued that basic salary and pay was often supplemented by allowances, fees and perquisites, and the possibility of lucrative corruption. Thus in 1776 the Secretary to the Military Department, Captain Kyd, had his military pay and allowances as well as his Rs. 400 a month as secretary: ${ }^{2}$ The perquisites and fees to the Secretary to the Governor-General in Council had amounted in the 1780 's to Rs.20,400 a year, ${ }^{3}$ collectors whose salaries were fixed in 1786 at Rs.1,500 a month, also received a commission on the revenues of from two to three thousand rupees a month. 4 Army officers made additional sums from bazar allowances, clothing funds and false muster rolls, 5 civilians from deliberately generous contracts, and from presents from revenue farmers

1. The ballad was published on 8 March 1787 in the Poet's Corner of the Calcutta Gazette and has been quoted in full in Appendix II to this thesis. W.S.Seton-Karr, editor, Selection from the Calcutta Gazettes, Vol.1, pp.196-8.

2. Misra, op.cit., pp.71-2.

3. Ibid.,p.77.

4. O'Malley, op.cit., pp.36-7.

5. Barat, op.cit., pp.63-4. 
or from the merchants who supplied goods to the Company. ${ }^{1}$ But even when, all such extras are allowed for, it remains the case that few servants of the Company could afford to marry in India. The days for making a fortune in Bengal passed quite soon. Even in the sixties, which were still marked by a scramble for wealth, an acute observer such as John Shore could notice how "the road to opulence" was becoming "daily narrower" as a result of the reforms started by clive. ${ }^{2}$ And this was actually felt by James Rennell. In 1764 he was appointed Surveyor-General in Bengal. He had an allowance of $£ 900$ which with other perquisites gave him just $£ 1,000$ at a time when he could enjoy his friend, his bottle and "all the necessaries of Life for $400 " .3$ And as he considered himself to be a less ambitious man than most, he hoped to return to England in a few years with a fortune of $£ 5,000$ or $£ 6,000.4$ After Clive had returned in 1765, Rennell found Bengal "surprisingly altered within a few years" and believed that after "long exile", he would be bbliged to retire on $120 £$ a year". 5

1. P.J.Marshall, The Impeachment of Warren Hastings, p.130 et seq.; 0'Malley, op.cit.,p.33 et seq.

2. Shore to his mother, 3 December 1769. Teignmouth, op cit., Vol.1, p.39.

3. Rennell to Burrington, 1 September 1764. H.M.1.Vo1.765, p. 138 .

4. Ibid.,p.137.

5. Rennell to Burrington, 1 July 1768 , Ibid.,p.186. 
By the last decades of the eighteenth century the situation had so much altered that for a man of average intelligence and luck India was "no longer a mine of gold". I During the debate on Pitt's India Bill in the House of Commons, Major John Scott informed the House that the time for making large fortunes was past and pointed out that from a total of five hundred and eight civil servants appointed from 1762 to 1784 only thirty-seven had returned to England, one hundred and fifty were dead and three hundred and twenty-one were still in Bengal and had not been able to return with fortunes. Out of the thirty-seven who had retired only two were meabers of Parliament, none had an immense fortune, many had less than $£ 20,000$ and some not a shilling. ${ }^{2}$ Pitt himself suggested in the House of Commons that after their first five years in India persons employed in the Company's service might be supposed to save out of their salaries $£ 2,000$ a year, without being suspected of peculation. 3 But scott, whose information was more accurate, ${ }^{4}$ declared that nineteen

1. Colebrooke to his father, 1785. Dewar, op.cit. p.181.

2. Debate in the Commons on Mr.Pitt's India Bill, July 16, 1784. P.H., Vo1.24, Col.1144.

3. Debate in the Commons on Mr.Pitt's India Bill, $21 \mathrm{July}, 1784$. P.H., Vol.24, Col.1168.

4. Scott based his speech on his research at the East India House, Leadenhall Street. See H.M., Vol.79, pp.1-2. 
out of twenty of the servants in India would be exceedingly happy at a prospect of being worth $£ 10,000$ after ten years. He added that not one in ten was worth a shilling at the end of ten years as the service of the Company of late years had not proved advantageous till after a much longer residence, though there might be a few exceptions. ${ }^{1}$ Thus it was not till Sir John Shore had spent thatry years in the country, of which and twetbe years in high office that he was able to return from India with a fortune of $£ 25,000$ "honourably acquired". Shore could have given a long list of persons who were not so fortunate. ${ }^{2}$ Holden Furber, therefore, does not exaggerate when he says,

"A brief acquaintance with the careers of Company servants in the last decades of the eighteenth century will convince any careful observer that they were not seeking after great fortunes. The day for that had passed, and the Company's records are strewnwith the wreckage of more than one large fortune whose possessor had once ranked as a great 'nabob'. Most of the lads /writers and cadets 7 who paid a ship captain a hundréd guineas and embärked with a seachest, a case of bottles, ' $\frac{1}{4}$ of a hundred of Castle Soap', 18 'cheque shirts', 2 velvet jockey caps, 2 wigs and three pounds worth of books ' of amusement and instruction' were seeking what was known as a competence." 3

\footnotetext{
1. Debate in the Commons on Mr.Pitt's India Bill, $21 \mathrm{July}, 1784$. P.H., Vo1.24, Cols.1164-5.

2. o'Malley, op.cit., pp.32-3.

3. Furber, op.cit., p.338.
} 
That competence by Wellesley's day was a very good salary, but even so it was only achieved after a number of years in junior grades at small or moderatey rates of pay.

It is clear, therefore, that throughout the years 1757 to 1800 only a few senior or fortunate servants of the Company could afford to marry an English wife and maintain her at the standard expected in Bengal. Even in the last decades of the century most of the men who went single from England were usually obliged to remain so, for a considerable number of years at least, ${ }^{1}$ and they could only view the few well-placed high officials who could marry as particularly blessed and happy. ${ }^{2}$ The situation of the large majority who did not marry was only rendered tolerable because concubinage with the women of the country was possible financially and socially tolerated. Concubinage was indeed the rule rather than the exception, ${ }^{3}$ and accepted even for churchmen. 4 As Innes Munro pointed

1. Letter from a correspondent "N.S.B." to the editor of the Calcutta Gazette, 20 January 1820. See Sandeman, op.cit.,p.338.

2. Cf. "He / $\bar{J}$ ustice Chambers at the supreme Court7 has ... a beătiful Wife and a lovely Child - Happy Man." See Mss.Eur.E.25, p.104.

3. "Here no Cranny /ẅriters colloquially described7 wants a wife" - Bengal Gazette, Calcutta, 16 to 23 December 1780, No.48; P.D.Stanhope, Genuine Memoirs of Asiaticus (edited by W.K.Firminger) p.34; J.W.Kaye, Christianity in India, p.95.

4. Francis to Rev.Stephen Baggs, 1775, See Mss.Eur.E.25. pp. 70-1. 
out, it was easier to support "a whole zenana of Indians than the extravagance of one English lady", 1 and by doing so one could continue to maintain that style of living which the money from the sarkar or money lender made possible. An elderly military officer who had kept an Indian harem of sixteen in Bengal, could say easily when interrogated by a friend as to what he had done with such a number: "Oh, I gave them a little rice, and let them run about!" ${ }^{2}$ Captain Thomas Williamson who wrote from twenty years' experience in Bengal, computes the expenses attendant upon concubinage, which depended greatly on the circumstances and disposition of the gentlemen concerned, at a maximum of forty rupees, i.e. £4, and a minimum of twenty-five rupees, i.e. £2.10s per month. 3

The situation in which the servants of the Company in Bengal, unable to afford marriage took to keeping Indian mistresses, was frankly accepted. Thus the newly elected managers of the Military Orphan Society when founding the institution in Bengal, wrote to the Court of Directors:

1. Munro quoted in Yule and Burne11, op.cit.,p.981. 2. Williamson, op.cit., pp.412-3.

3. Ibid., pp.414-5. Ten rupees were equivalent to one pound. See Auber, ㅇ․cit., p.162. 
"It need hardly be here observed that, not less than nine-tenths of the Company's servants abroad being, of necessity, unable to enter into matrimonial connections of a suitable kind, it would be equally fruitless and unjust to attempt, in any shape, to lay a restraint upon a sort of commerce which, though it may not be entirely defensible, is obviously rendered unavoidable by the very nature of our establishments in India. It is this equitable consideration which gives the helpless issue of such an intercourse that particular claim to the countenance and protection of the ruling power, which the illegitimate offspring of others do not possess." 1

The theory, expounded by Kaye and accepted by

almost all subsequent writers on the question, that it

was the small number of English women coming out to

Bengal that forced so many men to remain unmarried,

falls to the ground. Kaye wrote,

"If the opjportunity of contracting honourable marriages even at the large Presidency towns were few, at the out-stations it may be fairly assumed that there were none." 2

1. The managers to the Court of Directors, 29 March 1783. See J.Cooper, editor, Original Papers Relative to the Establishment of a society in Bengal, p.47, footnote.

2. Kaye, op.cit.,p.106. Kaye's theory has been reproduced by later writers like W.H.Hart (old Calcutta, p.29) and Lt.Col.Wolesley Haig (The Cambridge History of India, Vol.6, p.161). And it has been accepted even by a serious scholar like Henry Dodwell, (The Nabobs of Madras, p.210). He, however, admits that because of the low expenses on concubinage, mistress became a "recognised institution" in India among the English middle class people who could not afford "such Iuxuries" in England. There "Kitty Fisher's favours" were certainly reserved for the peerage. 
But his assumption that possible partners were lacking is wrong - it was the necessary funds to support them which were not available. ${ }^{1}$ One solution was offered by the gentleman who, in 1781 , advertised in the Bengal Gazette for a bride, giving a long list of desired accomplishments, but adding that any deficiency in these would be disregarded provided there was "an equivalent counter-balance of cash, to render matters smooth and pleasant". 2 Unhappily few of the ladies who made the arduous and costly voyage to Bengal to escape the dowry system in England could be expected to buy their husbands in Bengal. For most of the Company's servants the solution was not to marry. The correspondent who soliloquizes in imitation of Hamlet:
"To wed or not to wed - that is the question Whether 'tis happier in the mind to trifle The heats and tumults of outrageous passion Or with some prudent fair in solemn contract of matrimony join ..." 3

would have agreed with a fellow correspondent who advised the settlement,

1. Cf. "I have had some thoughts of getting a Partner ... but I find that Families are so very expensive in this Country /B̈engal/ that $I$ am afraid to venture; so that I must eñdeavoür to mortify those Desires till my Arrival in England" - Rennell to Burrington, 31 August 1765, H.M. Vol.765, p.150.

2. Bengal Gazette, Calcutta, 12-9 May 1781, No.17.

3. The India Gazette, Calcutta, 1 January 1787, Vol.7, No.320. 
"It would be absurd for a man in good health to take medicine, and if he be unhappy without a wife, he had better shoot himself at once, for he will never be happy with one." 1

In the writings of Captain Thomas G.W Williamson indifference to marriage with European women becomes positive opposition to any such idea. Williamson came to Bengal as a cadet in 1778 and retired from the service on half pay as Captain in $1796 .^{2}$ In 1810 he published The East India Vade Mecum - "a work professedly undertaken with the view to promote the welfare and to facilitate the progress" ${ }^{3}$ of the young servants of the Company and puts down in it the experiences of "a residence of more than twenty years in Bengal". 4

Williamson not only opposes the idea of shipping out English and Scottish girls to be married in Bengal, 5 but he also argues the economic case for keeping a harem of Indian mistresses, ${ }^{6}$ entering into detail about the costs

1. The India Gazette, Calcutta, 28 May 1787, Vol.8, No.341.

2. Dodwell and Miles, op.cit.,pp.270-1. There was another Thomas Williamson also a cadet and later captain at the same time as Thomas G.Williamson, the author of The East India Vade Mecum. The former officer died at Allahabad on 2 January 1799. Ibid., pp.268-9.

3. See the dedication of the author to the Court of Directors in Vol.1.

4. See preface to the same, p.7.

5. Ibid., pp.453-7.

6. Ibid., pp.451-3. 
of maintaining a "Hindustanee lady", ${ }^{1}$ with an openness which marks him as the true child of his times.

The writers and cadets who came to Bengal after 1784 were all mere boys, passing through the early stages of adolescence. Unless they were well connected and supplied with the right letters of introduction, the were doubtless subjected to all the miseries of loneliness and homesickness, incidental to and inseparable from the life of any newcomer to a foreign country. Even those who were well furnished with introductions, like the young Charles Metcalfe, might find themselves begging to leave India, at least until they found active employment up-country. ${ }^{2}$ Again, a little later, Macaulay writes after an experience of a much improved Calcutta:

"Let me assure you that banishment is no light matter. No person can judge of it who has not experienced it. A complete revolution in all the habits of life - an estrangement from almost every old friend and acquaintance - all this is, to me at least, very trying. There is no temptation of wealth or power which could induce me to go through it again." 3

These miseries of loneliness could not be driven away by marriage for the young writer or cadet had not

1. Williamson, op.cit., pp.412-51.

2. Edward Thompson, The Life of Charles, Lord Metcalfe, pp. 22-8.

3. Quoted in Busteed, op.cit., p.173. 
got the means to set up a European household. Many would, indeed, find it hard to avoid plunging into debt even with a batchelor establishment, ${ }^{1}$ as the possibilities of quick fortunes gradually died away. The tempting solution was thus to maintain an Indian mistress. This must have been the more tempting because though youngsters, the writers and cadets were officially called upon to act the part of men. Moreover, without the restraint of parents, relatives and friends, thrown together in Calcutta with others of their own age, many became "violent and intractable", as Kaye noted. 2 The Court of Directors also commented on "the total want of due and proper restraint and discipline on the part of the junior servants residing in the Presidency". 3 To keep a mistress may well have been one way of throwing off restraint and claiming adult status.

$$
\text { Even in thé earlier period before 1784, when }
$$

older men entered the civil service - General Smith described those going out in the 1770's as boys under seventeen or old men of over forty ${ }^{4}$ - who were already married, few brought their wives with them. Dislike of

1. Infra, Ch.V.

2. Kaye, "The English in India - our social morality" in Calcutta Review, op.cit.,p.299. Kaye has also made a sample study in his novel Peregrine Pultuney, publisher anonymously at London in 1844 .

3. Misra, op eit. p. 396.

4. Speech of Gen.Smith in the debate in the Commons on East India Recruiting Bill, 12 April 1771. See. P.H. Vo1.17, Co1.170. 
the voyage and uncomfortable conditions in Bengal deterred some wives, the need to care for children detained others, while the costs of a passage and of housekeeping in India debarred others. ${ }^{1}$ Many husbands, who found themselves thus separated from their wives consoled themselves with an Indian mistress. When Philip Francis came out to Bengal in 1774, his devoted wife stayed in England with her five young daughters and son. ${ }^{2}$ By 1776, however, Francis was confiding to Bourke, that he was living with "Black ladies without end". 3 John Shore during his early career in Bengal maintained a zenana. 4 He went home in 1785 , married in February 1786 and then in April was appointed to the Bengal Council. His newly married wife stayed in England because she dreaded the climate of Bengal; ${ }^{5}$ so Shore resumed his relationships with Indian women. ${ }^{6}$. Many

1. The last factor explains why the practice of bringing wives to India was generally confined to a few high officials, Councillors and Governors. See Walsh to Fowke, 20 April 1774. Mss.Eur.E.3, p.38.

2. Busteed, op.cit., pp.178-9.

3. Francis to Bourke, 20 March 1776, Mss.Eur.E.15.p.283.

4. B.B.M.B., Vol.2, p.285 and Vol.4, p.11.

5. Teignmouth, op.cit., pp.120-1.

6. B.B.M.B., Vol.4, p.52. 
Englishmen had children by their Indian mistress before marrying and bringing up a regular family - as for example Rennell whose natural daughters Elizabeth and Mary were baptized at Dacca in 1769 and $1770,{ }^{1}$ before his marriage to an English wife in $1771 .^{2}$ others even continued to keep a native mistress after their marriage. Thus in 1780 Captain Charles Russell Deare of the Artillery had two daughters baptized - Elizabeth his illegitimate daughter by an Indian consort, and Helen, his legitimate daughter by his wife Anne Catherine. ${ }^{3}$ Referring to the class of native women kept as mistresses by Europeans in Bengal, Williamson, the best authority on the subject, states that,

"Nine in ten of the women domiciled by gentlemen are Mussalmans, the Hindus being far more scrupulous: with few exceptions, the small portion not of the former sect are Portugueze." 4

These Portuguese were a body of half-castes and native Christians, the descendants or converts of the Portuguese colonies at Hooghly, Dacca and other centres in the Bay of Bengal. They were commonly known as "Firingy", 5 though not all had European blood in their

1. B.B.M.B., Vol.2, p. 483 .

2. Supra, Ch.III.

3. B.B.M.B., Vol.2, p.300.

4. Williamson, op.cit., p.413.

5. Holwell to Drake, 16 June 1755. Quoted in Stark, Hostages to India, p.13. 
veins, and in 1757, at the time of Nawab Siraj ud daula's capture of Calcutta there were some two thousand men, women and children of this class in the city, ${ }^{1}$ besides other groups in Chittagong, Dacca, Hooghly, Noakhali and Assam. ${ }^{2}$ On the predominance of Muslims in the zenanas of Europeans Williamson is supported by the Report of the Select Committed on East India Affairs appointed by Parliament in 1831-2. The Seledt Committee of the House of Commons reported that the greater part of the mothers of children by officers in the Company's service were Mohammedans of respectable families, but in reduced circumstances. They were in many instances Magbals and Pathans. 3 This report was based upon the minutes of evidence of J.W.Ricketts before the select Committee on 21 and 24 June 1830. Williamson is further supported by the evidence of wills recorded in Bengal, for where Europeans gave the names of the native women with whom they had lived in their wills, they prove to be in most cases Muslim. ${ }^{4}$ But these wills also point out what

1. Robert Orme, History of the Military Transaction of the British Nation in Hindusthan, Vo.1.2, Sec.2, p.61.

2. J.J.A.Campos, History of the Portuguese in Bengal, p.177.

3. Report of the Select Committee of the House of Commons on East India Affairs, 1831-2, P.P.(H.C.), 1831-2, \# 735, p.314.

4. For a few examples, see Appendix III. 
Williamson might have included in the category of "few exceptions" to the predominance of Muslim mistresses that in upcountry stations such as Kissenganj in Bihar the mistress of an Englishman could occasionally be a tribal woman. ${ }^{1}$

1. See Will of Capt. Edward Hall, filed and probate granted, 24 January 1798. B.W., 1798-9, Will no: 4. No volume no. No pagination. Also see below. 
The predominance of Muslim mistresses followed

from the fact that in the eighteenth century Muslims mixed socially with Europeans, whereas the Hindus, with their caste restrictions, especially on interdining did not. Williamson points out that a Muslim woman "under the protection" of an European was held by her countrymen in no disrespect, being treated as though she were married to him. According to Muslim law, there are various degrees of connubial attachment, from the strictest and most formal union down to a very loose kind of "left-handed marriage". 2 The Hindus, on the other hand, had little social intercourse with Europeans, and in the few cases where Hindus became the mistresses of Europeans, they were usually of low caste or such as had lost their caste, ${ }^{3}$ or as had been rescued from the

1. Spear, op.cit., p.130. Dr.spear discusses in detail the racial relations between the Europeans and the Indians in the eighteenth century in India.

2. Williamson, op.cit., pp.451-2.

3. Report of the Select Committee of the House of Lords on East India Affirs, 1831-2. Sœ P.P. (H.L.) 1831-2, Vol.9, \#735, p.300. 
funeral pile of their dead husbands. 1 It is notable that the unofficial wives or mistresses, whether Muslim, Hindu or Portuguese rarely gave up their own religion, customs, and way of life. 2 They had their own separate establishment provided by their European protector and seldom went out of their residence. 3

The refusal to change religion and custom led to the curious situation in the late seventeenth century when the Court of Directors encouraged their soldiers in Madras to marry Indian non-Christian women. 4 This

1. The case of Job Charnock, the founder of Calcutta, who rescued a Hindu widow from the funeral pile of her deceased husband and lived with her is well-known. An

interesting example in the second half of the eighteenth century is that of a civil servant, Gerard Gustavas Ducarel, who rescued a Hindu widow of rank from the funeral pile of her husband, lived with her and had several children. Ducarel who came to Bengal as a writer in 1765 and was later a friend of Francis, returned to England with his mistress and children in 1784 and settled in London by 1800. See Mirca Abu Taleb Khan, The Travels in Asia, Africa and Europe during the years 1799-1803, pp.198-9. For Ducarel's service career in Bengal, see "Three Biographical Notes" in the Journal of the Calcutta Historical Society, 1934, vol.46, p.45.

2. Williamson, op.cit., pp $345-6,413-4$.

3. A Young Civilian in Bengal, 1805, in the Journal of the Calcutta Historical Society, op.cit., p.125.

4. "The marriage of our soldiers to the Native Women of Fort st.George formerly recommended to you, is a matter of such consequences to posterity that we shall be content to encourage it with some expenses, and have been thinking for the future to appoint a $\mathrm{Pag}^{\mathrm{a}} / \overline{\mathrm{Pag}} \mathrm{g}$ a 7 to be paid to the Mother of any child that shāil heréafter be born of any such future marriages..." The Court of Directors to the President at Madras. See F.R. I.I. Vol.8, p.290. A pagoda was equivalent to eight shillings. Auber, op.cit., p.162. 
was done so as to prevent them from taking Portuguese wives and so adopting their religion, Roman Catholicism, which was seen as dangerous both politically and in religious terms. ${ }^{1}$ By the second half of the eighteenth century, however, such suspicion and hostility seems to have died away, for soldiers, ${ }^{2}$ N.C.O. ${ }^{3} s^{3}$ and non-official Europeans ${ }^{4}$ freely married into the Portuguese community, apparently without changing their religion, since their marriages were duly registered.

During the period under review there is only one entry in the marriage registers which seems directly to reveal the marriage of a European with an Indian woman. This was the case of John Davis, a sergeant-major of sepoys who on 20th April 1785 married Hannah Coreah who is described as a "Native Christian". 5 The term may mean

1. Until 1828 government posts in England were not open to Roman Catholics. See Asa Briggs, The Age of Improvement, p.230 et seq.

2. For some examples, see B.B.M.B., Vol.2, pp.49, 63, $163,211,261,273,275,278,433$; Vol.4, pp.56, 67-8, $107,113,141,147,163,177,195$; Vo1.5, pp.49-58, $137-143,229-236$ and $333-347$.

3. Ibid., Vo1.2, pp.163, 235 6, 249, 274, 434, 455 and the same as in Vols. 4 and 5 cited above.

4. Ibid., Voxid, pp.49, 63, 135, 220, 223, 249, 261, 280; Vol.4, pp.51, 101, 137, 171, 187, 191; Vol.5, pp. $33-48$ and $213-26$.

5. Ibid., Vol.4, p.11. 
what it seems - an Indian convert, or may here apply to the child of a European father and Indian mother, later baptized: the Portuguese name could cover either situation. It may be, of course, that English names in the registers sometimes conceal Indian women who had been baptized as adults before marriage to Europeans, for the baptism of nine adult Indian women is recorded at Berhampura;, a military outstation, in May 1799,1 probably as a preliminary to their marriage with English soldiers.

There are no Indian names to be found in the marriage registers and lists for Bengal. Stark has suggested that "frequently the marriage was performed in accordance with the civic customs of the woman's caste". 2 There is no evidence at all of any such ceremonies, nor is it clear what Hindu ceremony could have been invoked for a marriage with a non-Hindu. It would seem clear that marriages, if they took place, were preceded by conversion to Christianity and by baptism, and that in most cases where Europeans lived with Indian women they were not formally married to them at all. In the wills

1. B.B.M.B., op.cit., Vol.5, p.195.

2. Stark, op.cit., p.22. 
of the latter half of the eighteenth century in Bengal, where testators provided for women with whom they had been co-habiting, they were never described as wives, but as the mothers of their children, their housekeepers, their women, or the women of Hindusthan. ${ }^{1}$ Again, no names of Indian women can be traced in the lists of baptisms for legitimate children where the mothers' names are mentioned. The lists of baptisms for illegitimate children never mention the mothers except on two occasions where the mothers were European, ${ }^{2}$ and in one of these cases the woman later married the father of her natural child. 3

It has been argued that it was the economic inability of many Europeans, official and non-official, to support an English wife and familty in Bengal, rather than shortage of possible mates, that kept the number of marriages to so low a figure in Bengal, at this period. As Williamson clearly puts it:

1. Will of Alexander Maclure, $18 \mathrm{June}$ 1787. Probate granted 21 June 1787; Will of William Kirton, 10 October 1780. Probqte granted July 1787. See Will nos. 18 and 20 in B.W., 1787-90. No volume number and no pagination. Also see Appendix III.

2. B.B.M.B., Vo1.2, p.219 and Vo1.4, p.171.

3. Ibid., 
"Such is the increase of domestics, of cloathing, of accommodation, and particularly in keeping a carriage, without which no comfort can be expected, that it is utterly beyond the means of full four persons in five to receive an European lady into their houses." 1

But if the alternative was to set up a zenana, and to live with an Indian woman without being recognised in the eyes of the law as man and wife, this did not prevent many such arrangements becoming marriages in all but name. So in Berhampur Ensign Sherrock had his little family of Indian Mistress and Child. ${ }^{2}$ In Tirhoot, William Orby Hunter, an indigo planter, settled into domesticity with his Indian mistress attended by several slave girls. ${ }^{3}$ In Calcutta, that very well-known figure William Hickey, advocate of the Supreme Court, built a very costly, handsome house in Hooghly for his lovely Zemdanee, ${ }^{4}$ where she performed the duties of a wife by joining Hickey in entertaining his guests. 5

Until a few years ago there hung on the wall of the room of the Parliamentary Under Secretary of State for India

1. Williamson, op.cit., p.455.

2. E.I., Vol.2, pp.131-7.

3. Ibid., Vol.4, p.387 et seq.

4. Hickey, op.cit., Vol.4, pp.115-6.

5. Ibid., Vol.3, p.327. 
in London an unfinished oil painting by Zoffany in 1786 , which depicts General William Palmer, once Military Secretary to Hastings, and his family, consisting of Faiz Baksh, a Begum of the Oudh royal family, their two sons and daughter, two Indian female attendants and the Begum's sister. ${ }^{1}$ Many such unrecognised marriages were very enduring, and in some cases mistresses and children were taken to England by their 'husbands', upon their retirement from the services of the company. ${ }^{2}$ Williamson comments that the devotion given to their Indian mistresses sometimes amounted to "an infatuation beyond all comparison", 3 and no doubt Rudyard Kipling's moving story, "Yoked with an Unbeliever" or Sayed Mujtaba Ali's Bengali story, Tuni Mem, ${ }^{5}$ had often had its counterpart in real life.

1. Journal of the Calcutta Historical Society, 1929, Vol.38, p.179. For a view at the portrait of the Palmer family by Zoffany, see Ibid.,1930, Vol.39, plate facing page 67. And for more about Palmer's children, see below.

2. Mirja A.T.Khan, op.cit., p.198.

3. Williamson, op.cit., pp.344-6.

4. Rudyard Kipling, Indian Tales, Vol.1, p.37 et seq.

5. Sayed Mujtaba Ali, Tuni Mem, p.l et seq. 
Irregular unions with Indian women were accepted as inevitable in eighteenth century Bengal, as williamson ${ }^{1}$ or Kaye ${ }^{2}$ makes very clear. That is not to say however, that they were socially acceptable: a Hickey or a Palmer were exceptional in making their liaisons so open and public. Again the Anglo-Indian wives of members of the Company's military or civil services were never fully accepted in European society in Bengal. Williamson comments that though such wives might be the natural daughters of men holding one of the highest ranks in the King's or Company's services, but by an Indian mother, nevertheless they were never invited by the Governor-General to public assemblies or entertainments. 3 The Rev. Tennant similarly comments that either such wives were excluded from society, or, if accepted, they were treated with "caution and ceremonious reserve". 4 The position of the children of Indian mistresses occupied an equally anomalous and uncertain position. They were usually brought up by their fathers like the

1. D'oyly, op.cit.,pp. $\mathrm{Cc}^{1}$; Also by the same author,
Costume of Modern India, p.Xx. In both cases the
preface has been written by Williamson.

2. Kaye, op.cit., p.106. Both Kaye and Williamson describi the attachment of the young writers and cadets to the Indian women as a result of "an admitted want".

3. Williamson, op.cit., p.457.

4. Tennant, op.cit., p.72. 
children of legitimate European marriages. They followed their fathers in religion, dress, habits, customs and language ${ }^{1}$ and were sent to England for education by all those who could afford the expense. 2 As Innes Munro wrote in March 1780:

"If you were only to examine all the seminaries in Britain for the education of youth it would be found that nearly one out of ten in the numbers they contain is of that description. "3

By the term "of that description" Munro refers to coloured children, though this inciudes children from the West Indies as well as India. There are many letters which testify to the concern and affection for their Anglo-Indian children displayed by the servants of the

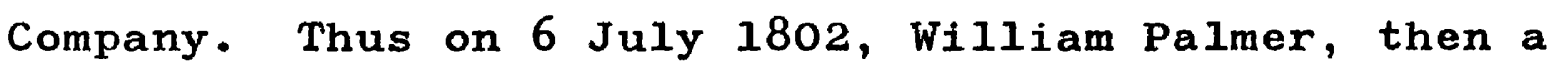
colonel in the Bengal Army, writes affectionately to Warren Hastings about his natural children:

"All are good and sensible \& have been well
educated in England." 4 . After educating them in England, Palmer had infiltrated his sons into the services of the Company. As he writes in the same letter:

1. Report from the select Committee of the House of Commons on East India Affairs in 1831-2. P.P.(H.C.) 1831-2, Vo1.9, \#735, pp.314-5.

2. The managers of the Military Orphan Society to the Court of Directors, 29 March 1783, Cooper, op.cit.,pp.45.

3. Innes Munro, A Narrative of the Military Operations,

4. Palmer to Hastings, $6 \mathrm{July}$ 1802. W.H.P., Addl. Mss.No. 29178, p. 240 . 
"My natural children are in comfortable \&
reputable employments, civil \& Military." The same care is found equally among the non-official members of the British community: Samuel Potter, an opulent merchant, thus directs the trustees for his infant natural son in his will, to

"send him to a boarding school in England, the further from London, in my opinion the better, on his attaining the age of ten years that he may have a thorough arrethmatical Education."

Likewise Francis Fowke, reflecting on "the uncertainty of life", had sought in his will to provide for his Indian mistress and his illegitimate children. ${ }^{3}$

How large a problem the provision for natural children was in the European community in eighteenth century Bengal cannot be accurately estimated. However, a minimum figure can be arrived at by a study of Bengal wills. Thus in 1798 altogether forty-four wills were made by Europeans in Bengal, and in thirteen of them provision was made for Indian mistresses and the children born by them. of the thirteen,three wills were made by military and one by a civil servant of the Company,

1. Palmer to Hastings, $6 \mathrm{Ju}$ ly 1802,

2. B.W., 1798-9, Will No.41. Probate granted 26 November 1798. No volume number. No pagination.

3. Will of Francis Fowke, Calcutta $18 \mathrm{July} \mathrm{1781,}$ Mss.Eur.F.3. Fowke Mss.K.22, pp.30-1. 
six by non-officials, and three by persons whose occupation cannot be determined. ${ }^{1}$ If 1798 could be assumed to be a representative year, this would give well over five hundred wills in our period in which illegitimate Anglo-Indiah children were provided for. Another approach to the problem is by a survey of the lists of baptisms sent annualy from Calcutta to London, in which large numbers of natural children can be traced. Records for the town of Calcutta are available for the whole of the period, but for outstations in Bengal only for the periods 1769 to 1781 and 1788 to 1800. Moreover, even the Calcutta series is imperfect. The list for 1781 only covers the months from January to April ${ }^{2}$ and that for 1782 those from June to october. 3 Again the list for 1793 is totally illegible, 4 and cannot be read even with the aid of a magnifying glass.

It is clear, therefore, that the total of the baptisms of natural children which can be laboriously calculated from the lists of baptisms of Calcutta and

1. The serial numbers of wills which provided for the mistresses and the children arè $2,4,7,8,19,29$, $34,35,39,40,41$ and 44. See B.W., 1798-9, No volume number. No pagination. Also see Appendis III.

2. B.B.M.B., Vol.2, pp.302-3.

3. Ibid., p.457-8.

4. Ibid., Vo1.4, pp.155-6. 
the outstations must underrate the true number. In any case not all such children were brought up as Christians, for those who were deserted by their fathers and left without provision, were doubtless brought up in the faith of their mothers as Muslims or Hindus. ${ }^{1}$ The children of the brief irregular unions formed by the European troops, royal or Company, must frequently have been so abandoned. Again the absence of any baptismal entries for natural children from the Calcutta lists for 1762$67^{2}$ shows that such baptisms were not always recorded or mentioned.

1. Report from the Select Committee of the House of Lords on East India Affairs in 183I-2. P.P.(H.I.), 1831-2, Vol. 9\# 735, Ð.300.

2. B.B.M.B., Vol.2, pp. 78,85-9,105-6,113,131 and 135. 
Even so, the paternity of 869 natural children baptised at Calcutta and of 556 baptised in the outsettlements has been established for the period, with the following results:

Table 3, showing the baptisms of natural

children in Bengal, 1757-1800.

At Calcutta At outsettlements

$(1757-1800) \quad(1769-81 ; 1788-1800)$

Military Servants (Army and Navy

398

534

Civil Servants

77

3

Medical Servants

12

10

Outside the services (nonofficials)

118

3

Undetermined cases

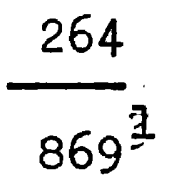

6

$556^{2}$

1. Ibid., pp.47,55,64,153-4,183-4,197, 210, 218-9, 223-4, 237-8, 250-2, 262-4,283-301,302-3 (Jan-Apr. 1781), 457-8 (June-0ct.1782), 449-50, 467-69, covers 1755-83; Vol.4, pp . 7-9,11-2,27-8,36-8, $43-4,51-3,84-7,102-3,124-6,137-8,155-6,171-2$, 187A-8,191-3 covers 1784-96;

Vol.5, pp. 1-11,89-104,173-86 and 269-84 covers $1797-1800$.

2. Ibid., pp. 483-9 covers 1769-81; Vol.4,pp.56-9, $69-74,107-9,113-7,141-2,147-9,163-5,177-8,195-6$ covers 1788-96; Vol.5, pp.1-29,105-119,189-210 and 285-310 covers the rest of the years until 1800 . 
It is clear, both from the incomplete list of natural children provided for by will, and from the fuller, if still incomplete lists of baptism, that the care and upbringing of such children had become a major social problem in Bengal. In some cases, as has been seen, individuals treated their illegitimate children as members of the family and made arrangements for their education, even sending them to England for that purpose. By the last decade of the eighteenth century, moreover, there were a number of charitable institutions for the care of such children, "seven or eight...for... boys and and equal number for girls." 1 But there were also many cases where the fathers merely abandoned their children and their mothers, and there were also many cases where children were left orphans, without

1. Tennant, op.cit., p.70. 
provision for theirupbringing. This was particularly the problem of the army, where death in action and even more by disease took a constant toll, leaving numbers of orphaned illegitimate children uncared for.

By the early seventeen-eighties the need for British society in Bengal as a whole to accept responsibility had been recognised and proposals to found a Military Orphan Society in Calcutta were made. The plan owed its origin to the assiduity of a few officers who took this step to
"reconcile many a valuable officer and deserving man to his dissolution whose last moments have been imbittered by poignant and agonizing reflections, occasioned by anxiety for the fate of the desfitute offspring which he was to leave behind him."

Among them Colonel William Kirkpatrick, secretary to General Giles Stibbert, then commander of the Bengal Army, was conspicuous. 2

In March 1783, a plan which had met with the almost universal concurrence of the officers was laid before the Governor-General-in-Council for the mantenance and education of the orphans of army officers. It was proposed to support the orphanage by making monthly deductions from all officers' pay: nine sicca rupees from

1. The managers of the Military Orphan Society to the Court of Directors, 29 March 1783, Cooper, op.cit.,p.4? 2. Williamson, op.cit., pp.459-60. 
a major, six from a captain or surgeon, three from subalterns and assistant-surgeons. ${ }^{1}$ By the fourth article of the plan the affairs of the society were to be managed by a governor, a deputy governor, and twelve managers, chosen from the officers of the army. ${ }^{2}$ In all, provision was to be made for the care of one hundred children. The scheme met with the approval of the Governor-General in Council, who made an additional grant of three rupees a month for each child accepted. In May 1783 the support given to the officers' orphanage encouraged the Society to enlarge its scope. General Stibbert accordingly wrote to the Court of Directors to report that the managers of the society had offered to take care of the orphans of non-commissioned officers and privates too, if the grant was raised from three to five rupees per child. The Court turned down the offer, but nevertheless the Society added two hundred children of non-commissioned officers to the number in its charge. Ten years later, however, the Directors relented and made the grant requested for children of non-commissioned officers and privates, allowing it from the age of three

1. H.M., Vol.85, p.52. See also the first article of the plan in Cooper's Original Papers, p.12.

2. Cooper, op.cit.

3. H.M., Vo1.85, pp.50-1. 
when children were accepted from parents. ${ }^{l}$ From thenceforward both the Upper Orphanage for the children of officers, and the Lower Orphanage for those of other ranks received the Company's support. They had already agreed, in 1786 , to house the society in a building estimated to cost some sicca Rs. $40,000 .^{2}$

To the suggestion of the society that the children of commissioned officers should be sent to England for their education and for entry into the Company's services, the Court of Directors in their same letter of 14 March 1786 objected firmly. ${ }^{3}$ In 1791 they went further and declared the illegitimate sons of British fathers and Indian mothers ineligible for the services of the Company. In that year the Committee of Shipping which was responsible for approving persons going to the East, acquainted the Court of Directors that one John Turing who had been nominated a cadet for Madras appeared to be a son of a British father and Indian mother. He was interviewed at the meeting of the Court on 19 April 791, and the Court resolved unanimously:

1. B.L.R., Vo1.35, Para 57. No pagination. 31 January 1795 Williamson, op.cit., pp.462-3.

2. D.B., Vo1.14, Para 54, p.557. Resolution no.9. 14 March 1786. Eight sicca rupees were equivalent to one pound. See Auber, op.cit., p.162.

3. Ibid., Para 54, pp.546-7. Resolution no.2. 
"That no Person, the son of a Native Indian, shall henceforth be appointed by the Court to employment in the Civil, Military or Marine Service of the Company." 1

It is evident that this resolution of the Court was to be treated as a standing order of general application, for in the margin of the Court Book was written the initials "S.0.". 2 When the Committee of Shipping later asked for a clarification of the resolution, the Court, at its meeting of 9 November, extended the description of posts closed to Anglo-Indians to include the sworn officers of the Company's ships between Europe and India, and made this too a standing order. ${ }^{3}$ These orders had not prevented persons of mixed descent from serving as privates in the Company's forces. But the discriminatory policy of the Court reached its climax when at their insistence the Governor-General-in-Council passed a resolution in 1795 whereby all persons, not descended from British or European parents on both sides, were declared disqualified forever from service in the army, except as fifers, drummers, bandsmen and farriers. 4

The immediate effect of these tesolutionswas not
1. C.B., Vol.100, p.17.
2. Ibid.,
3. Ibid., Vol.100A, p.576.
4. Stark, op.cit., pp.58-9. 
merely to prevent the entry of Anglo-Indians into the Company's armies, but to bar those already in them, however they had distinguished themselves, from continuing in the service. The case of John Nairne, the son of a British father and Indian mother, will illustrate how the resolutions worked. He had entered the marine service of the Company before the passing of the standing orders of the Court. On 21 January 1795, he petitioned the Court to dispense with their orders in his favour so that he could remain in the service. ${ }^{1}$ at their next sitting, on $28 \mathrm{January,} \mathrm{his} \mathrm{case} \mathrm{was} \mathrm{taken} \mathrm{up,} \mathrm{but} \mathrm{was}$ decided against him. Nevertheless, he was allowed to proceed to India as a free mariner on the ground that he had entered into the service of the Company previous to the date of the standing orders and had made two voyages to and from India on board one of the Company's ships. ${ }^{2}$ Those who were dismissed from the army in India, generally transferred their services to the native states, mainly to those of Scindia and Holkar. They were allowed to do so on the condition that they would be liable to be called back by the Governor-General-in-Council, if

1. C.B., Vol.103A, p.1004.

2. Ibid., pp.1008-9. 
the Company went to war with these Indian powers. 1

When employment in the Company's services was thus closed to Anglo-Indian boys, no alternative was immediately available, for whereas in the Madras Military Orphanages the boys were taught various trades, ${ }^{2}$ in the calcutta Military ${ }^{3}$ and private orphanages ${ }^{4}$ no such training was provided. It was only with the growth of the bureaucracy in Wellesley's day 5 and of mercantile houses in Calcutta ${ }^{6}$ that a wide field of employment as clerks opened up. Others distinguished themselves as doctors, schoolmasters, architects and preachers, and yet others became printers, carvers, gilders, or undertakers; were apprenticed to tradesmen or went into indigo planting. 7

1. Minutes of evidence by J.W.Ricketts before the Select Committee of the House of Lords on East India Affiars, 31 March 1830. See P.P.(H.L.), 1830, Vo1.6, \# 646,p.18c

2. Maria Graham, Journal of a Residence in India, p.128.

3. See articles 1-27 of the plan of the Military Orphan Society, Cooper, op.cit., pp.11-21.

4. Tennant, op.cit., pp.69-70 and Williamson, op.cit., p. 464 .

5. See Misra, op.cit., pp.404-6 for the growth of the class of monthly writers - that is uncovenanted servants of the Company.

6. Williamson, op.cit., pp.467-8.

7. Minutes of evidence before the Select Committee of the House of Commons on East India Affairs, 21 June 1830. P.P.(H.C.), 1830, Vol.5, \#655, pp.39-40. 
As for the girls in the orphanages, in Madras they were trained in needlework, ${ }^{1}$ and in Calcutta, especially in the Upper Orphanage as housekeepers for Company servants. ${ }^{2}$ The condition of those brought up from their infancy with private foster parents was usually miserable. A small number of them became ayahs, laides' maids or children's nurses, but the majority wandered about in search of any poor employment they could find. 3 If they were good-looking they were often engaged as "housekeepers to single gentlemen", as Williamson puts it, ${ }^{4}$ a description which doubtless covered the status of prostitute, mistress or concubine.

It is important now to examine the grounds on which the Court of Directors based their policy of discrimination towards the Anglo-Indians in the last decade of the eighteenth century. This question has hitherto received little attention, except in Stark's Hostages to India. There he argues that the policy was

1. Graham, op.cit.,
2. Tennant, op.cit., pp.71-2.
3. Williamson, op.cit., p.337.
4. Ibid.


based on fear that the Anglo-Indians might become politically dangerous and upon colour prejudice. According to Stark, it was feared that the AngloIndians might enter into alliance with the natives of the country and agitate for a Black Republic as had happened in Spanish America and San Domingo ${ }^{1}$ towards the end of the century, as he puts it,

"The revolution of Hayti and San Domingo must be made impossible." 2

However, Stark either does not know, or ignores the fact that the Court of Directors had launched their policy of discrimination against Anglo-Indians immediately after the establishment of the Military Orphan Society, long before the mulatto rebellions in Spanish America and San Domingo in the early 1790 's. ${ }^{3}$ Again, Stark bases his argument upon the assumption that the Court was influenced by the views of Lord Valentia, who during his travels in Bengal in 1803 warned everyone against the dangers of a Black Republic being established in India like that in Spanish America. ${ }^{4}$ But to assume

1. In pp.68-75 Stark gives a detailed account of this Black Republic. Is.

2. Ibid., p.56.

3. See above.

4. Viscount Valentia, Voyages and Travels to India, Ceylon, the Red Sea, Abyssinia and Egypt in the years 1802-6, Vol.1, p.197. Stark quotes Valentia, as his authority, in pp.69-70 of his work. 
that warnings given in Lord Wellesley's day influence the policy of the Directors, enunciated in 1791, is to commit an obvious historical anachronism. Nor, in fact, is there any evidence that there was any political danger from the Anglo-Indian community. As a class they showed themselves very loyal to British rule in Bengal, so that the government there, which had treated them so ill in expelling them from its services was able to exploit their loyalty. ${ }^{l}$ stark himself tacitly admits this point when he says that the Anglo-Indians who were serving the Marathas, when called back to fight on behalf of the British against their Indian masters in $1801-5$, readily responded. 2

Stark also argues that the policy of the Court arose partly from a contempt for dark-skinned races. He writes:

"There are indications that secret or avowed contempt for people of mixed origin was undoubtedly an ingredient of the motives by which the Court of Dirbctors were actuated." 3

No doubt many Englishmen in India had always entertained a contempt for Indiahs when they refer, to them as 'blacks' or 'niggers'. In 1780 Innes Munro was to be found issuing a warning against sending Anglo-Indian children

1. See footnote no.4 on previous page.

2. Stark, op.cit., p.81 et seq.

3. Ibid., p.75. 
to Great Britain:

"It was by this means that the Spanish and Portuguese got so much of the dusky hue in their countenances having kept an unrestrained intercourse with their colonies till they were ${ }_{1}$ reduced to their present despicable state."

Cooper also relates that at the time when the Military Orphan society was being established at Calcutta, a section of the British community objected to the plan for sending boys of mixed parentage for education in England on the ground that this would lead to a degeneration in British society. ${ }^{2}$ Colour prejudice can likewise be glimpsed from the letter of Colonel Palmer to Hastings, written in 1802, in which he discusses what is to be done about two natural sons of his dead friend Julius. He frites:

"The oldest Boy, whose age is about seven year is fairer than the ordinary run of these children, but is still discernible in his complexion to be of Native Mother. He has a fine Countenance, mild, open \& intelligent \& bears a strong resemblance to his poor Father ... The youngest Boy is so dark that if his Mother is not absolutely black, he scarcely can be poor J's son, although he was acknowledged. He is a cheerful Boy \& more sturdy (yet not strong) than the oldest - about 4 years old, but dull or probably idle. It can never be adisisable that this Child should go Home." $B$

1. Munro, op.cit., p.51.

2. The managers of the Military Orphan Society to Sir Eyre Coote. 18 November 1782. Cooper, op.cit., pp.29-3C

3. Palmer to Hastings, 21 August 1802. W.H.P., Add1.Mss. No. 29178, pp.254-5. 
But to admit the existence of colour prejudice is not to prove that it was such prejudice that led the Directors to act as they did. Stark has not provided any efidence to substantiate his argument - he does not even quote Cooper or Innes Munro. Had fear of miscegenation been at work, one might have expected the Court of Directors to seek powers to ban the entry into or to order the deportation from England of the children of mixed descent who were then drifting "in swarms". in the streets of London. ${ }^{1}$ No such move was ever made, though the French had actually taken such action, by issuing an edict that no sable or tawny-coloured foreigners should ever be permitted to remain above eight days in France and that they must immediately return by the first ship to their own country. ${ }^{2}$ Valentia, on whom Stark otherwise relies as an authority, was in fact to urge the very opposite of the French policy. He had appealed to British fathers of half caste children in India, "to send them to Europe, prohibiting their return in any capacity whatever", his idea being to prevent their forming the nucleus of a "Black Republic" in India."

1. Munro, opicit., p.71.

2. Ibid., p.51.

3. Valentia, op.cit., p.198. 
What guided the policy of the Court of Directors was a consideration for their own interest and a concern for their reputation in India. Clearly the appointment of boys of mixed descent in their civil, military and marine services would limit the usefulness of their powers of patronage. Anglo-Indians could only be given posts at the expense of their own relatives, friends and political allies. ${ }^{1}$ It was this which led them in 1785 to write to the Governor-General complaining that they were "put to great expense" by tolerating the indulgence given to their military officers of appointing their infant sons (by Indian women) as junior cadets. ${ }^{2}$ They therefore first acted to prevent such children being sent to England for the education necessary for their entry into the Company's services, and then resolved to bar them from the services. The upper or covenanted services had been closed to outsiders in 1791 , the lower grades of the services were closed in $1795 .^{3}$

1. Supra, Ch.II.

2. D.B., Vol.14, para 11, p.152. 21 September 1785.

3. This view that the Directors acted to safeguard their patronage is supported even by the exceptions which the made to their own rule. In 1830 when J.W.Ricketts was under examination by the select Committee of the House of Commons, he was asked, "You named a number of officers of the class of East Indians who are employed in the Company's army; how came they to be employed, as the Company have a rule that they shall not be admitted in the army?" To this Rickett's answer was prompt and short: "I merely state the fact; I do not pretend to account for it, some of them were admitted prior to the prohibition." (See Minutes of evidence by 
The Directors may also have been concerned about the British image in India. By the last decades of the eighteenth century the Company had definitely emerged as the major Indian power. Cornwallis insisted that the Governor-General should be treated in all respects as the equal of every Indian ruler, and that nothing should be done which savoured of dependence or inferiority. ${ }^{1}$ At the same time Dundas, stressing that the government of Bengal depended upon a limited number of covenanted servants, pointed out that an indiscriminate and unrestrained emigration of Europeans to India would destroy or rather eradicate that general feeling among the natives of the superiority of the European character which the covenanted servants had instilled. He gave as an example the hatred and distress created among the natives by the behaviour of a number of vagrant Europeans during the reign of Mir Kasim, which had wounded British prestige. ${ }^{2}$ It would be natural in such circumstances to

(continued from pervious page) - J.W.Ricketts before the Select Committee of the House of Commons on East India Affairs, 24 June 1830, P.P.(H.C.), 1830, Vol.5, \# 655, p.47) Had Ricketts studied the private correspondence of David Scott, the East India Director he would have replied that it was some members of the Court of Directors, previously in India in the service of the Company, who were responsible for this interested breach of regulation. (See Scott to Inglis, 14 July 1797. H.M., Vol.730, pp.82-3.)

1. Charles Ross, editor, Correspondence of Charles, First Marquis Cornwallis, Vol.1, p.216.

2. Debate in the Commons on the renewal of the East India Company's Charter, 23 April 1793. P.H., Vol.30, Col. 670 . 
exclude Anglo-Indians from the services, who were looked down upon by Indians not because of their colour but because of their social origin. At a later date such fear of debasing the British image certainly found expression. On 21 June 1830, when J.W.Ricketts was under examination by the Select Committee of the House of Commons, he was bluntly asked,

"Are you not aware that the original exclusion of persons of your description from the Company's stervice was an exclusiofi founded upon the beief of your colour and your appearance being likely to affect you in the estimation of the natives of India?" 1

In the Report of the Select Committee it was clearly stated that the Court of Direcfors believed that if men of mixed descent were allowed to hold positions in the services of the Company, it would deliver a blow to their prestige in the eyes of the natives who despised them because of their low and outcaste mothers. 2

The oppressive discriminatory policy of the Court of Directors could not, of course, prevent the continuing

1. Minutes of evidence of J.W.Ricketts before the select Committee of the House of Commons on East India Affairs, 1830. P.P.(H.C.), 1830 , Vol.5,\#655, p.45.

2. Report of the Select Committee of the House of Lords on East India Affairs in 1831-2. See P.P.(H.L.), 1831-2, vol.9, \# 735, p.300. 
growth of a community of mixed descent in Bengal. How rapidly that community grew has already been indicated by reference to the records of wills and baptisms, though no precise figure can be worked out. Rather later evidence shows that growth received little check in the first decade of the nineteenth century. In 1802 it was found that in the United Charity and Free School at Calcutta ${ }^{l}$ the students born to purely European parents were far outnumbered by those of mixed origin. ${ }^{2}$ A Police Committee Report of 1822 estimates that at that time the Christian population in Calcutta was 13,138, of which 2,254 were Europeans and the remaining 10,884 were Anglo-Indian men, women and children. ${ }^{3}$ In 1830 Ricketts estimated that there were 20,000 Anglo-Indians in the whole of Bengal, and that two-thirds of them lived in Calcutta alone. 4

A few members of this large community were able to merge themselves into the British community by marriage.

1. This school was founded in 1731 by the Company's Chaplain and his Church Wardens. See H.B.Hyde, Parochial Annals of Bengal, p.90.

2. Ibid., p.244.

3. Minutes of evidence by J.W.Ricketts before the słlect Committee of the House of Lords on East India Affairs, 31 March 1830.P.P.(H.L.), 1830, Vol.6,\#646, p.190.

4. Minutes of evidence by J.W.Ricketts before the Select Committee of the House of Commons on East Ifidia Affairs, 21 June 1830. P.P.(H.C.), 1830, \#655,p.36. 
British soldiers and non-commissioned officers frequently married Anglo-Indian girls and took them back to England. It was also the policy of the managers of the Military Orphan Society to look for British husbands in the Company's services for the girls in their charge, especially those of the Upper Orphanage. ${ }^{1}$ Some AngloIndian girls thus overcame the disadvantage of their mixed parentage. A most notable example of this was provided by the daughter of Governor Crook of Fort St. David by an Indian woman. She married four Englishmen in suceession, including William Watts, Governor of Fort William, and William Johnson, Chaplain on the Bengal establishment. 2 In 1769 Amelia, her daughter by Watts, married Charles Jenkinson, first Earl of Liverpool. 3 Their son, Robert Bank Jenkinson, second Earl of Liverpool was Prime Minister of England from $181 \$$ to 1827.4 When Amelia's mother, the Begum Johnson, died in 1812 , worth $£ 50,000,5$ she received a funeral worthy of the grandmother of a future Prime Minister.

1. Tennant, op.cit., pp.71-2.

2. Mss.Eur.E.15, p.104.

3. Sidney Lee, op.cit., Vol.29, pp.309-10.

4. Ibid., pp.311-5.

5. Mss.Eur.E.15., p.104. 
She was then the oldest European resident in Bengal, and her funeral at St.John's Churchyard was attended by Lord Minto, the Governor-Geheral, in his state coach drawn by six horses. ${ }^{1}$

The fate of most Anglo-Indians was naturally far less fortunate and splendid. Though numbers of "men of talent and education" ${ }^{2}$ were found in their community, their position in general was miserable. They might claim British fathers, but bore the stigma of illegitimacy. They were not considered to be British subjects and therefore could not claim the jurisdiction of the Supreme Court if they lived in the mofussil. Since they were equally not Indians, they had no rule of civil law by whose standards they could regulate their affairs. Professing Christianity they were outside the pale of the Hindu or Muhammedan codes of civil law, and so lacked any law to regulate their marriages, to define the legitimacy or illegitimacy of their issue, and to prescribe and regulate succession. While up country,

1. Journal of the Calcutta Historical Society, 1930. Voi.39, p.53.

2. R.G.Wallace, Fifteen Years in India, p.96. For a brief study of the biographies of such talented and educated men from the Anglo-Indian community, see East India Worthies by H.A.Stark and E.W.Madge. 
they were amenable to the Muslim criminal law, even if they happened to be born of Hindu mothers. ${ }^{1}$ Men like Williamson were ready to defend the contracting by the Company's servants of irregular unions with Indian women as the answer to an otherwise insoluble economic and social problem. Those who founded the Military Orphan Society, the other civilian orphanages, and the charity schools, recognised that society had some obligation to the offspring of such unions. The personal interest of the Directors and the supposed interests of the Company as ruler of Bengal prevented any adequate and humane fulfillment of that obligation.

1. Report from the Select Committee of the House of Lords on East India Affairs in 1831-2. P.P.(H.L.), 1831-2, Vol.9, \# 735, p.301. Some Europeans residing in the interior, seeing the legal disadvantages under which Anglo-Indian Christians laboured, brought up their children as Muslims. Thus at Kissenganje in Bihar, Captain Edward Hall brought up his sons by two Indian mistresses as Muslimsnand never had them Christened. See Will of Edward Halk, filed and probate granted, 24 January 1798. B.W., 1798-9, Will No. 4, No volume number, no pagination. 
Part 2

The Nature of Social Iife 


\section{CHAPTER V}

\section{HOME LIFE}

In pre-Plassey days, the servants of the East India Company in Calcutta used to live in dark and damp lodgings in the Fort,amid the warehouses and offices in which they spent their working days. ${ }^{1}$ They met for dinner and supper at a common table, taking their seats according to their rank, presided over by the Governor of the settlement, and at night the gates of the Fort shut upon them. ${ }^{2}$ Their life thus bore a strong resemblance to that of an Oxford or Cambridge college - or to that of a great merchant household in London, where the master slept with his family over his place of business, "servants and prentices above in the garrets, and porters and messengers packed away anywhere in cellarage and warehouses"? In 1756, outside the fort there were only some seventy British houses in Calcutta, according to Blockman, 4 though

1. C.R.Wilson, editor, old Fort William in Bengal, vol.1, $\mathrm{p} \cdot \mathbf{x x}$.

2. Spear, op.cit.,p.11.

3. G.M.Trevelyan, Illustrated English Social History, vo1.3, p.44.

4. H.Blockman, Calcutta during Last Century, p.12. 
whether these were freehold or rented from Indian owners he does not say. Most of these were grouped round the fort, and were presumably mainly occupied by non-official Europeans and free merchants, men such as Dumbleton, then the only attorney in Calcutta, whose house in 1755 was rented for the use of the Company writers. 1

The siege and capture of old Fort William by Siraj-uddaula, with attendant destruction in the EngIish quarter round about it, meant that after Clive had retaken Calcutta, new arrangements had to be made to house the Company's servants. ${ }^{2}$ The growth of the garrison and the influx of large bodies of European officers and troops from Madras also greatly increased the demand for accommodation. 3 Initially the junior servants of the Company had to make do with small quarters of bamboo mat and thatch and the seniors with roughly patched up houses. 4 The building of a

1. Bengal Consultations, 1 September, 1755, quoted in Rev.J.Long, editor, Selections from Unpublished Records of Government...of Bengal, Vol.1, Sec.156, p.60.

2. Orme Papers, vol.164 (A), p.26.

3. Kathleen Blechynden, Calcutta, Past and Present, pp. 129-30.

4. Letters to Court, 29 December 1759, Para.84, quoted in Long, op.cit., Sec.399, p.165. 
new Fort William was at once set in hand, but it was necessary in the meantime to grant allowances for house rent and permit individuals to find their own accommodation. With the growth both of wealth and a new sense of security after Plassey, new housing sprang up along the existing roads, the Avenue, Pilgrim Road and Bow Bazar and bypassing the native quarters of Dinga, and Colinga, spread over the open ground of Chowringhee and Dharmatallah. The villages, fields, tanks and water courses between the main lines of road steadily gave way before the advancing town. 1 The Company's officials and officers thus escaped from the old confines of the Fort and its collegiate life. It was not the intention of the Directors that they should do so. In the letter of 4 March 1767, for example, after deploring the license and extravagance of the junior servants of the Company they laid down:

"As soon as apartments can be got ready in the new Fort, the writers must be accommodated there and the allowance for house rent must be struck off and no writer permitted to reside out of the new Fort without the express permission of the Governor, which must be minuted together with the reasons upon your Proceedings." 2

1. In 1764 the Court of Directors ordered Calcutta to become a Presidency town. See orme to Mitchel, 29 October 1764. Orme Papers, vol.XV, p.4134. Also see map of 1784 in N.K.Sinha, editor, Fort William - India House Correspondence, vol.5, p.527.

2. Sinha, op.cit., p.22. 
After fuller instructions restricting the writers to one servant and a cook, and no palanquin or horse, the Directors added the further order: "No writer shall be permitted either for himself or jointly with others to keep a country house." 1 A year later and the Directors returned to the same subject with new vigour,-declaring themselves extremely solicitous to have the new Fort completed and "to have the Governor reside and the Company's business carried on there entirely instead of having the different offices dispersed about the town in the manner they are at present." They therefore ordered that one large house already completed in the Fort be used as offices, and that the barracks there be adopted for apartments of the junior servants "with all expedition". ${ }^{2}$ In the same vein they expressed displeasure at the purchase of a house and godowns, costing Rs.30,000 for the Import Warehouse-keeper mainly because "it carries with it the idea of our servants adopting sentiments with respect to the new Fort very different from our intentions, which are to have the whole of the business carried on there". They concluded:

1. Sinha, op.cit., p.22.

2. Ibid., p.83. 
"You are to tender accommodation to all our Servants as fast as they can be got ready and if they decline residing in them, the Company's houses they inhabit are to be sold and if they persist in living out of the fort it must be at their own expense." 1

The hopes of the Directors were vain - up country, at Patna, Murshidabad or Dacca and the factories of Malda, Lakhipur and Balasore the old collegiate life survived for a while, ${ }^{2}$ but in Calcutta the servants could never be induced to accept life within the walls of the Fort. It did not even prove possible to cut off house rent allowance when the Fort was completed: in 1785 it was resolved that a field officer having no quarters in barracks should draw Rs $90 /-$ and a subaltern Rs 60/- while civilians above the rank of factor ranked as field officers, and factors and writers as captains for the allowance. ${ }^{3}$ The fears of the Directors, that license to live out would lead their young writers and cadets into extravagance and debt were, however, fulfilled.

1. Sinha, op.cit., p.84.

2. Despatches to Bengal, 3 March 1758, para.144 in Long, op.cit., Sec.311, p.130; M.E.Monckton Jones, op.cit., p.36.

3. Calcutta Gazette, 30 June 1785. See Seton-Karr, op.cit., vol.1, pp.81-2. 
Francis, writing to Robinson in 1776 about the problems of writers and cadets, commented:

"To send a youth out in either capacity without a certainty of being received into some good family is more hazardous than people in England are aware of." 1

It was doubtless such considerations which led the Company to lease the house of Richard Barwell to provide accommodation for their writers. The house contained nineteen apartments, each furnished with a separate set of out-offices, and the rent was Arcot Rs.200/- per month for each apartment. ${ }^{2}$ Writing in $1782-3$, Sophia Goldborne described the house, by then known as Writers' Buildings, as "the monument of commercial prosperity" of the East India Company. ${ }^{3}$

In view of the fact that a writer's house-rent allowance was fixed in 1785 at Rs.90/-a month, the rent of the quarters in Writers Buildings seems very high. But with the rapidly increasing European demand for private accommodation, as numbers grew and more

1. Francis to Robinson, 8 September 1776. Mss.Eur.E.13, Francis Mss.36K47, p.769.

2. Blechynden, op.cit., pp.199-200. One Arcot Rupee was equivalent to two shillings and three pence. Auber, op.cit., p.162.

3. Sophia Goldborne, Hartly House, vol.1, p.100. 
family establishments were set up either with English wives or Indian mistresses, ${ }^{1}$ rents in Calcutta were everywhere high. Who the landlords were can probably only be discovered by research in the archives of the Mayor's Court and Supreme Court in Calcutta, though it is known that Omichand, the wealthy Sikh involved in the conspiracy against Siraj-ud-daula in 1757, owned many Calcutta houses ${ }^{2}$ and let them to servants of the Company, ${ }^{3}$ but it is certain that there was an active market in urban property. The advertisements in the contemporary gazettes clearly testify to the demand for houses and the high rents obtainable. In 1774, upon his arrival in Calcutta, Philip Francis paid $£ 600$ a year for a house which he described as a barn, 4 and from 1776 he paid $£ 1,200$ a year in rent, though this for a

1. J.T. Wheeler, editor, Early Records of British India, p. 216 .

2. Edward Thornton, History of the British Empire in India, vo1.1, pp. 209-10.

3. Bloctiman, op.cit., p.12.

4. Francis to Lord Clive, 30 November, 1774. Mss.Eur.E.18, Francis Mss.K53, Letter no.7, no pagination. 
house which he described as the finest in Bengal. 1 Two years later Hickey was paying $£ 300$ a year for a cutcha house on the Esplanade, ${ }^{2}$ that is, a house built of sundried brick or mid and probably thatched. Ten years later when Cornwallis was reviewing the cost of living in Bengal, in order to press the claim of the Company's servants for more adequate pay, he estimated that the generality of them were obliged to pay rents of from $\$ 350$ to $\$ 850$ for their accommodation. 3

It may be wondered how the junior servants of the Company with their low initial salaries and meagre allowances managed to house themselves. One answer was, of course, for batchelors to club together to rent a house, in the style of a modern chummery. Another was to live away from the fashionable European quarters of the higher officials. Nrs. Fay, the wife of a barrister of the

1. Francis to Bourke, 20 March 1776, Mss.Eur.E 15, p.283. Dr. Busteed locates this house on the site later occupied by the Oriental Bank, at the corner of old Fort Ghant Street and Clive Street, to the north of the Calcutta Theatre (built in 1775) behind Writers' Buildings. See pp.120-1. For a description of the house, see below, p.

2. Hickey,op.cit., vol.2, p.134.

3. Cornwallis's minute of 31 January 1788 on the salary question quoted in A.Aspinall, Cornwallis in Bengal, $\mathrm{p} .37$ 
Supreme Court thus writes to her friends in the early $1780^{\prime} \mathrm{s}:$

"Our house costs only 200 rupees per month because it is not a part of the town much esteemed; otherwise we must pay 3 or 400 rupees. 1 $M_{a}$ ckrabie solved his problem by living with Francis:

"Neighbour Collings and I must contribute towards it. We are bound to do so, I swear, we have no wives nor children." 2

Many, however, must have taken the fatally easy way of borrowing from sircar or banyan, and running into debt.

Only the more senior members of the service were able to build, for until a fortune had been accumulated no one could be expected to lay out the Rs.30 to 60,000/which Sophia Goldborne estimated as the cost of a house in the early $1780^{\prime},^{3}$ or the'Rs.50,000/- which Williamson laid down, at the end of the century, as the minimum cost, including labour, of building a substantial house of burnt bricks and good lime, with masonry roof supported by stout timbers, for a small family. ${ }^{4}$

1. Mrs.Eliza Fay, Original Letters from India (edited by E.M.Forster), p.181.

2. Mss.Eur.E.25, p. 104 .

3. Goldborne, op.cit., vol.1, p.87.

4. Williamson, op.cit., vol.2, p.11. 
Of the housing of the non-official European community of Calcutta - the 12 teachers, 11 surgeons, 2 portrait painters, 2 architects, 4 hairdressers, 3 jewellers, 12 tailors, 25 cabinetmakers and carpenters, 9 music teachers, 2 bookbinders, 5 printers, 10 auctioneers, 8 shipwrights, 1 chemist, 1 carver, 1 gunsmith and 1 engraver, the 48 leading merchants and agents and their 38 clerks, and the 30 barristers and their clerks listed for 1793 by Holden Furber ${ }^{1}$ there is much less information. The craftsmen probably had rooms over their workshops, others may have lived in boarding houses and taverns. There are many instances of licenses being granted to non-official Europeans to maintain taverns and punch-houses. ${ }^{2}$ The latter particularly provided for ships' petty-officers and salilors, and other low-class Europeans, who paid heavily and fared badly there, ${ }^{3}$ if contemporary accounts are to be trusted. The early houses built by the Europeans in Bengal were made with walls of sun-dried brick or beaten earth,

1. Furber, op.cit., p.257.

2. C.R.Wilson, editor, Early Annals of the English in Bengq1, vol.1, pp.276, 301 .

3. An Officer, Sketches of India, p.93. 
and with thatched roofs. These were reasonably cool but much exposed to the hazards of fire $^{l}$ and the assaults of the monsoon. From the middle of the eighteenth century, with advancing wealth, safer, more durable materials were used, though probably with some loss in coolness, brick, tiles and cement. The style of the house, with few doors and small windows and lofty rooms ${ }^{2}$ probably reflected Indian practice with its emphasis on privacy and security as much as English building styles. It would have been appropriate up-country, in the plains, where thickness of walls and close shuttering of the house is still the best protection against the dry summer heat, but in Calcutta with its damp, heavy air it must have been quite unsuitable in the absence of any cooling device such as punkah or fan.

In the second half of the eighteenth century this plan of building was discarded. Houses normally were now of two stories. On the lower or ground floor there were a series of small rooms, low-arched, dimly lit and

1. In 1767 a fire which broke out at Patna almost destroyed the Company's thatched cottah and the godown. The Bengal Consultations of 18 May 1767 decided that in future all Company's buildings should be made of brick. See Long, op.cit., Sec.910, p.479.

2. Williamson, op.cit.,p.7. 
ill-ventilated. These rooms were store houses and godowns, with heavy doors strongly barred and small windows heavily shuttered against thieves. The living rooms were on the first floor and consisted of a large central hall, with high airy rooms on either side and broad verandahs before and behind, ${ }^{1}$ used after the heat of the day had subsided. These rooms were approached by a broad easy staircase, which continued to the flat roof where the air could be taken in the morning and evening. ${ }^{2}$ Mackrabie's description of Philip Francis' particularly splendid house sets out the plan:

"There is a drawing room on the upper story $/ \bar{s} i c 7$ above fifty feet long, a dinning /sic7 room $\bar{b}$ selow as large - besides two spacious hälls, and a suite of three rooms upon each floor to the East and West - that is, fourteen rooms in all, with a principal staircase and two back staircases. The apartments are proportionately high. Twenty-five feet I believe." 3

The arrangement of the rooms is not unlike the Mughal style of bungalow developed in Bengal, but the style of the house, with its classical pillars and porticoes, and its balustraded roof is typically European. The same

1. Dodwe11, op.cit., p.164.

2. Grandpré, op.cit., vol.2, p.12.

3. Mss.Eur.E.25, p.110. 
style was to be found in Madras, which may have influenced Bengal as officials and officers came horth after 1756, and it is reminiscent of the colonial style in the West Indies. Who planned the buildings is again unknown, though Hickey,often refers to a successful Italian architect in Calcutta named Tiretta whom the Bengal Gazette ridicules as "Nosey Jargon" but who earned a fortune in Bengal, and the list of non-official Europeans for 1793 gives two architects in Calcutta. However, this was a great period for building in England, with many magnificent country 'seats' gnowing up all over the country, ${ }^{2}$ so that many individuals must have been acquainted with building in the classic style at home, and there were also a number of military engineers available in the settlement.

In the last decade of the eighteenth century, as the coolness of the ground floors came to be realised, the mass of store rooms and godowns at that level ${ }^{3}$ came to be done away with and replaced by living rooms. ${ }^{4}$ Two factors may have assisted this change - the move away from the city centre and its commercial quarters into purely

1. Hickey, op.cit., vol.3, p.140.

2. J.H.Plumb, England in the Eighteenth Century, p.101.

3. Despatches to Bengal, 3 March 1758, paras.56-7. See Long, op.cit., Sec.295, pp.124-5.

4. Williamson, op.cit., p.9. 
residential areas around Chowringhee, Park Street, Dharmatallah, Jaun Bazar and the Esplanade, ${ }^{l}$ which meant that warehousing space was no longer needed; the second the greater sense of security which allowed of houses built to stand in their own compounds and gardens without massive ground floor defences against thieves and dacoits. At the same time the introduction of the punkah and of tatties permitted a lowering of the ceiling and reduction in the size of windows, permitting a house of more modest scale and cost. In all these developments Indian influences upon European architecture in Calcutta seems slight, except perhaps in the plan of the house and the use of the verandah, where Mughal influence may be visible. Certainly in the external style, European Calcutta was Italian rather than Bengali, both in its public and in its private buildings. St.John's Church, built by subscription in 1787, thus has a semi-circular range of pillars of the Doric order and an architrave and cornice ornamented with triglyphs in the best classic manner. ${ }^{2}$ Thomas Daniel's plates of the Council House and of Chowringhee, published in 1797, show both public and private building fashoned to the classical idiom. ${ }^{3}$

1. Wallace, op.cit., pp.64-5.

2. Grandpré, op.cit., p.11.

3. Thomas Daniel, oriental Scenery, vol.2, plates 3 and 4. 
By 1780 Eliga Fay was describing the Esplanade as "composed of palaces", ${ }^{I}$ and "the city of palaces" became the common epithet for Calcutta from admiring travellers. None of the buildings were palaces Delhi or Fatehpur Sikri much more correctly might have claimed the description - but grouped as they were, often with open spaces to set them off, with their white chunam gleaming in the clear sunshine on pillars and porticoes, they were a striking sight to the traveller jaded by a long voyage at sea. ${ }^{2}$

The comfort of the houses of Calcutta was improved in this period by the increasing use of glass, of punkahs and of tatties, of which only the first was a regular European device. In the early years of our period glass was still very costly and was rarely used. It is true that Mrs. Kindersley wrote in 1768 that many of the newlybuilt houses in Calcutta had glass windows, ${ }^{3}$ and Dr. Spear goes so far as to say that "glass had been in common use by the English since the mid-century". ${ }^{4}$ But against this

1. Fay, op.cit., p.172.

2. William Hodges's description of the Calcutta houses as Grecian temples in his Travels in India during the years 1780-2, pp.15-6, clearly shows the extent to which a traveller could be influenced by theitr appearance.

3. Mrs. Kindersley, Letters from the Island of Teneriffe... and the East Indies, p.279.

4. Spear, op.cit., p.50. 
must be set the statement of Sir John Shore that in 1769 he found Calcutta:

"...consisting of houses, not two or three of which were furnished with venetian blinds or glass windows, solid shutters being generally used, and rattans, like those used for the bottoms of chairs, in lieu of panes." 1

As late as 1782 Sophia Goldborne could still write that the only house which could boast of glass windows, was that of the Governor-General. ${ }^{2}$ Apart from any question of cost it would seem likely that the general use of glass instead of shutters must have awaited the development of a feeling of settled security and the transition from houses which were half godowns to those which were purely residential.

Probably of more importance than the use of glass in making houses comfortable was the introduction of tatties. There were screens, usually made of khas, a fibrous root, which were fixed to open doors and windows and kept constantly wet. The air blowing through them was cooled by evaporation, the hotter and drier the breeze the more noticeable being the effect. ${ }^{3}$ Carey quotes

1. Lord Teignmouth, op.cit., vol.1, p.24.

2. Goldborne, op.cit., p.33.

3. J.Johnson, The Influence of Tropical climate on European Constitution, p. 461 . 
a letter of Dr. Campbell to show that tatties were first used in Bengal at Calcutta in the summer of 1789.1 But there are earlier references in English sources. Mrs Fay thus mentions the use of tatties in the description of the Governor-General's house in $1780,{ }^{2}$ and Margaret Fowke, writing to Lady Clive from Qasimbazar in 1783 comments:

"The heat would be more intolerable than it is in Calcutta, if they did not cool the schorching/sic 7 winds by tatties which perhaps your Ladyship recollects."

This would suggest that their use was known in the 1760's when Clive was in Bengal. Evidently, however, they only became generally popular in the last decades of the eighteenth century.

The other cooling device introduced at this period was the hanging punkah, a heavy cloth fixed to a wooden beam and hung from the ceiling which could be pulled to and fro by a rope to stir the air. ${ }^{4}$ Dr.Busteed, comparing the letters of Sophia Goldborne, 1783-84, who speaks of a punkah as a "fan made of a branch of the palm

1. W.H.Carey, op.cit., vol.1, p.103.

2. Mrs.Fay, op.cit., p.175.

3. Fowke to Clive, 28 sept.,1783. Mss.Eur.F.3,

Fowke Mss.K.22, p.175.

4. Yule and Burnel1, op.cit., p.742. 
tree" and an account of a hanging punkah by Grandpré in 1789-90, places the introduction of the true punkah between 1784 and 1790. He adds that it was invented by a Eurasian clerk and not introduced by the Portuguese as a Calcutta chronicler had suggested. ${ }^{1}$ His arguments are, however, invalid. The coming of the punkah to Bengal cannot be regarded as an 'invention'. The hanging punkah in some form or other was certainly known to Mughal India, for, in July 1663 François Bermier while describing the typical house of a Mughal noble at Delhi says:

"Elle [cette maison] ait de Caves avec de grands evantails qui agitent l'air pour reposer à la fraicheur depuis le midy jusque sur les quatre ou cinq heures que l'air de ces Caves commence à se faire chaud et étoufant".

The punka may thus have come to European Bengal as a result of the increasing contact with North India which had begun since the acquisition of the Dewany in 1765 . Again, in the Bengal inventories of the Calcutta Supreme Court which open in the India Office Library from 1774, there appears in the inventory of the estate of Richard Becher, who died on 3 June 1783, the item "I Cloth Punkah". 3 The introduction of the hanging

1. Busteed, op.cit., p.97.

2. Francois Bernier, Voyages de Francois Bernier, Vol.2, p.19?

3. B.I., Range 1, Vol.4, No. 4I, no pagination. 
punkah in Calcutta must evidently be put before that date. Dr. Spear's claim, based on the evidence of Hickey, that the punkah was fairly well-known in Calcutta before $1785^{1}$ may thus seem to be confirmed. However, the hanging punkah was still not universally used even at the end of the century. The fact that the judges of the Supreme Court had to change their linen several times a day during the trial of Nanda Kumar in $1775^{2}$ suggests that punkahs were not then provided in the Supreme Court. In 1800

1. Spear, op.cit., p.97.

2. Dennis Kincaid, British Social life in India, p.86. 
Lord Wellesley had to order their installation in St.John's and other churches of Calcuttal, while as late as 1808 Mr. Lathrop found it necessary to announce that hanging punkahs had been installed at Moor's Rooms "on account of the warmth of the season", as a means of swelling the thin attendance at his lectures on mechanics. ${ }^{2}$ Again, Williamson, writing in 1810 , does not mention any punkah puller in his exhaustive list of domestic servants. 3

Usually only the dining room was fitted with a hanging punkah. An illustration by D'Oyly of 1813 shows such a punkah complete with decorative frill pulled by a Khalasi, in use over a dinner table. ${ }^{4}$. It would seem that the device had been improved since its introduction, for in this illustration there are none of the personal servants stationed behind each chair with palm-leaf fans such as Grandpré had described in $1790 .^{5}$ The punkah, pulled by a single servant, may thus have reduced the size of the domestic labour force.

1. C.B.Lewis, The Life of John Thomas, p.31.

2. Carey, op.cit., p.124.

3. Williamson, op.cit., vol.1, p.185 et seq.

4. D'Oyly, op;cit., plate 8 .

5. Grandpre, op.cit., p.11. 
From illustrations such as those of D'Oyly and from the inventories of the Mayor's Court and the Supreme Court, Calcutta, available here from 1755 and 1774 respectively, it is also possible to see how houses were furnished at this period. ${ }^{1}$ (Houses were usually let unfurnished so that individual tenants had to purchase their own furniture.) The influences displayed are clearly English rather than Indian - in particular nobody dispensed with tables and chairs. It would seem indeed that much of the furniture was imported from Europe, despite the heavy costs involved, through such agents as Towers and Allen, Roach and Johnston, Baxter and Ord whose advertisements are found in the gazettes. ${ }^{2}$ The presence of English carpenters and cabinet-makers in the non-official community of Calcutta, doubtless armed with the pattern books common at this period in England, indicates, however, that there was some local production in the English style. Even so furniture seems to have been comparatively expensive and the junior servants of the Company and the less opulent among the non-officials

1. See Appendix IV.

2. See Seton-Karr, op.cit., vol.1, pp.38,44,47. 
had to make do with a minimum of furniture. ${ }^{1}$ The climate and the presence of vermin and insects prevented the use of wallpaper and wainscotting - walls instead were furnished with chunam to give a light, shining surface. Mirrốs and pictures were commonly used to break the plainness of the walls, ${ }^{2}$ though the pictures were here of the present generation rather than of family ancestors as at home. A number of painters visited Calcutta, 3 the most notable being Zoffany who reached the city just in time to paint the portrait of Sir Elijah Impey before he sailed home in December 1783.4 He also sketched other notables of the day such as Sir John Chambers, another judge of the supreme court, 5 besides providing the "Last Supper", which still hangs in St.John's Church, built in 1787.6 One eastern habit, though one by now naturalised

2. J.Johnson, The Oriental Voyager, p.108; Rev.J.Long, "Calcutta in the Olden Times" in T.S.Smith's Selections from the Calcutta Review, vol. 8, p. 286 .

2. Mrs.Kindersley, op.cit., p.278.

3. Journal of the Calcutta Historical Society, 1931 , vol.42, p.136.

4. Busteed, op.cit., p.105.

5. Joseph Fowke to his daughter, Margaret, 27 May, 1784. Mss.Eur.E.5, Fowlse Mss.K.26, p.85.

6. H.E.A.Cotton, Calcutta Old and New, p.479. 
in England, was the use of carpets and rugs for the floors, ${ }^{1}$ but few other signs of Indian influence are : noticeable in the Calcutta houses.

The move out of the cramped. quarters of old Fort William and from the commercial area around it into the more open Chowringhee area was accompanied, as has been seen, by a change in the style of house. It also permitted indulgence in the English taste for gardens. With sone difficulty the lawn appeared and the kitchen garden of England. Many English vegetables could be grown in India: cabbages, cauliflowers, lettuces, celery, beets, carrots, turnips, peas, cucumbers and melons, beans and potatoes, whose advance upcountry can be traced from Calcutta in the early decades of the nineteenth century. To these were added local gourds of various kinds, capsicums, egg-plants, love-apples, sweet potatoes and yams. Fruits were also grown in abundqnce - peaches, nectarines, grapes, a few apples but no pears, together with such sub-tropicals as guavas, pineapples, oranges and limes, pomegranates, mangoes, comringahs and currindahs. 2 In the introduction of new vegetables and fruit trees they were able to draw upon the experience

1. Mrs.Kindersley, op.cit.

2. Williamson, op.cit., vol.1, p.264. 
of those great botanists and horticulturalists the Dutch, up river at Chinsurah, 1 and in the arts of Asian gardening from Chinese gardeners ${ }^{2}$ who probably came by way of Sumatra and Java. In the style of their gardens, however, they were very English. As Dr. Spear puts it, the English garden in India was not:

"a fresco of ornamental water and playing fountains and shady pavilions like the Moghul, a Dutch garden in marble, but one of wellkept lawns, and laden fruit trees, as in 'England's green and pleasant land'." 3

As an extension to the habit of creating town gardens, the well-to-do officials and non-officials maintained garden or country houses to which they repaired during the hot and rainy months, Calcutta's sickly season. 4 So Mrs Fay writes from Calcutta in iNovember 1780 :

"My times has passed very stupidly for sone months, but the town is now beginning to fill - people are returning for the cold season." 5

1. Williamson, op.cit., vol.2, pp.150-1.

2. Ibid., vol.1, pp. 265-6.

3. Spear, op.cit., p.50.

4. Topham to Burrington, 22 Septembet, 1765. H.M., Vol.765, p. 152-3.

5. Mrs. Fay, op.cit., p.188. 
The British in Bengal thus achieved something of the pattern of the aristocracy and wealthy at home, coming up for the London season while Parliament was in session ${ }^{1}$ and then returning at the beginning of June to their country seats. 2 In Bengal it was the climate which dictated the move to the country or suburbs, not the ties of estate management and of county affairs, but the result was to provide a winter season at Calcutta as in London.

The first reference to a garden house in Bengal occurs in 1762, though similar houses at St.Thomas Mount may be found at an earlier date in Madras. ${ }^{3}$ This was the purchase of a garden house, at a cost of ten thousand rupees, for the President-in-Council. 4 In the same year the Council proceedings record the grant of a license to a merchant named Parker to convert a garden house he had purchased as a resort for the Calcutta gentry into a house of entertainment. ${ }^{5}$ clive had a garden house at 1. E.N.Williams, Life in Georgian England, p.41 et seq. 2. Ibid., p.46 et seq.

3. H.D.Love, editor, Vestiges of Old Madras, vol.2, pp. 504-6, 557 .

4. Despatches to Bengal, 19 Feb.,1762, Para.40. Long, op.cit., Sec.593, p.283.

5. Bengal Consultations, 21 June 1762. Ibid. Sec.579, p. 277 . 
Dum Dum and Warren Hastings had another at Alipore, with a splendid garden. ${ }^{1}$ By 1768 Mrs Kindersley was able to report seeing a number of garden houses round about Calcutta. 2 Many of these were situated on Garden Reach, just below Calcutta, with attractive views of the river. In 1780 Mrs Fay describes them as "elegant mansions...surrounded by groves and lawns which descend to the watery edge". 3 They varied in theit external features but were all one storey buildings, with flat roofs protected by balustrades, many windows with green venetian shutters, porticoes and verandahs, and were stuccoed with fine chunam polished until it looked like marble. ${ }^{4}$ They presented a charming sight to passengers from England coming up by boat to Chandpal ghat, the main landing state, ${ }^{5}$ and were described in 1812 as similar to "villas in the neighbourhood of London." 6

I. Bengal Consultations, 21 June 1762, op.cit.,p.xxix.

2. Mrs.Kindersley, op.cit., p.218.

3. Mrs.Fay, op.cit., pp.171-2.

4. Capt.and Mrs.Sherwood, The Life and Times of Mrs. Sherwood, 1775-1851, (edited by F.J.Harvey-Darton), p.357

5. Ibid.,pp.259,357; Robert Lindsay, "Anecdotes of an Indian Life" in Lives of the Lindsays (edited by Lord Lindsay), vol.3, p.156.

6. Lady Nugent Maria, Journal of a Residence in India, 1811-5, vol.1, p.12 $\overline{3}$. 
The early garden houses, one storeyed thatched buildings made of cutcha or sun-dried brick, might cost five thousand rupees, according to Williamson's estimate. ${ }^{1}$ Hastings, however, spent some sixty thousand rupees on the garden house of Belvedere at Alipore, which had belonged to Verelst and which he b*ought from Cartier. He also spent heavily on Hastings House, also at Alipore, sending to Benares for marble for its staircase. ${ }^{2}$ He had yet another house on his plantation at Sooksagar where he often spent the weekend, ${ }^{3}$ and according to Marshman he

had yet another country residence out of Calcutta at Rishera,

1. Williamson, op.cit., vol.2, p.11.

2. Keith Feiling, Warren Hastings, p.87.

3. The country residence of Warren Hastings at Sooksagar, on the banks of the Hooghly, a little above, and on the opposite side to, Bandel, passed through the hands of Croftes, Barretto and Lauruletta. In 1792 it was called "Chota Calcutta" but in 1829 the place was silent, deserted, and sad, and covered by the dark tangled grass which hid the snakes and the jackals. See Colesworthy Grant, Rural Life in Bengal, pp. 29-30 and Journal of the Calcutta Historical Society, 1914, vol.9, pp.66-9. As for the Hastings House at Alipur, it was purchased jointly by Turner and Thompson while the rest of the estate was sold by lots. See Feiling, op.cit., p.328.

4. J.C.Marshman, "Notes on the Right Bank of the Hooghly" in Smith, op.cit., vol.1, p.760. 
near Serampore, the Danish settlement. Most magnificent of all, however, was the country house at Barrackpore, built by Wellesley. 1

To these garden houses families were despatched for the worst months of the Calcutta year, and to them escaped the husbands, Company servants or free merchants, for the weekends. Since by regulation of 1766 no one was allowed to go more than ten miles outside Calcutta without the Governor's permission - a measure designed to prevent junior servants of the Company from neglecting government business ${ }^{2}$ - the garden houses were all within easy reach by palanquin, on horseback or by river. (Hastings usually travelled to Alipur in his budgerow.) The Directors' despatch of 4 March 1767 forbade writers to keep a country house, or a horse or a palanquin, but the order does not seem to have been applied. By the end of the century the maintenance of country houses, or weekend cottages as they might be called today, appears a well-established institution.

Information is fairly full about housing in and around Calcutta, but scanty for the up-country stations.

1. Carey, op.cit., vol.1, p.81.

2. Bengal Consultations, 24 March 1766. Long, op.cit., Sec.845, pp. $436-7$. 
The early factories at such places as Dacca and Qasimbazar were to be found within the Mughal city, but as at Calcutta this period saw the creation of European stations outside the narrow, dirty and unsanitary city lanes. For the factors at Qasimbazar there were garden houses at Mandipur, ${ }^{I}$ and at Benares a European station at Secrole. ${ }^{2}$ The Company's forces likewise formed cantonments outside the native cities - the Council at Fort William promising in their despatch of 14 september 1767 to avoid quartering troops within a city "being well aware of the bad consequences which such a measure is too frequently attended with". 3 so cantonments arose at Bankipur, three miles outside Patna, at Dinapur, Berhampur and Barasat outside Calcutta. ${ }^{4}$ In both civil and military lines the bungalow was the commonest structure, single-storey, thatched roof, buildings made of sundried brick - though again set in lawns and gardens. 5

1. Feiling, op.cit., p.18.

2. Rev. Reginald Heber, Narrative of a Journey through the Upper Provinces of India, vol.1, pp. 277-8.

3. Sinha, op.cit., p.333.

4. Tennant, op.cit., vol.1. pp. 322-3.

5. Williamson, op.cit. vol.1, p.514 and vol.2, p.34. 
Warren Hasting's correspondence describes the island home of Cleveland, the collector of Bhagalpur, a house with a flat roof in the calcutta style, ${ }^{1}$ but at Lucknow, Crofte's house is described as a bungalow. ${ }^{2}$ Since government did not provide houses, which had also to furnish the office space, for its officials, there are also references to the purchase and sale by incoming. and departing district officials, which indicate that upcountry most of the houses were cutcha, though even so an expensive item. 3

The houses and gardens of late eighteenth century Bengal were all, even the modest bungalows, unthinkable without an army of servants. As an example of the extremes to which the employment of servants could run, we may refer to the experience of the Rev.W.Tennant who served as a chaplain in India:

"For some time after my arrival", he wrote, "I lived in a private family, where the servants of all descriptions amounted to an hundred and five." 4

1. Feiling, op.cit., p.258.

2. Ibid., p.315.

3. Aspinall, op.cit., p.137.

4. Tennant, op.cit., p.63. 
This may be compared with the staff maintained in their country houses by wealthy gentry such as the Bests in Kent, or Dudley North in Sussex, thirteen in the one household, eight in the other, at the beginning of our period. Even in later years when establishments had grown, the wealthier of the English aristocracy could not match the profusion of servants employed in some Calcutta houses. 1

That so many servants could be maintained was due to the low wages that were paid; that so many had to be maintained was due to the demands of both the Hindu and Muslim religion. For the Hindu it was the caste system which multiplied the number of servants, making the occupation of each perfectly distinct. ${ }^{2}$ This it was which made the newcomer from England wonder:

"... why the sweeper could not be allowed to make the bed, the bearer would refuse to clean the boots, or the clerk to dust his papdrs, why one man was required exclusively to fill his hookah, another to cool the wine, and a third to wait at table." 3

1. G.E.Mingay, English Landed Society in the Eighteenth Century, pp. $230-32$.

2. Williamson, op.cit., vol.1, p.181; Mrs.Mindersley, op.cit., p. $2 \overline{8} 2$.

3. Spear, op.cit., p.51. 
A ruslim servant, for his part, would do nothing forbidden by the Quran, he would not, for example, touch pork, he would not serve wine. ${ }^{1}$ A European wishing to economise on servants and to ignore their scruples was very likely to be faced with a strike or boycott by his servants. ${ }^{2}$

It was in vain, therefore, that the court of Directors laid down that "no writer shall keep more than one servant besides a cook", 3 and denoumed the charge for wages of domestic servants "of almost every denomination", debited to the Buxey's account by their President at Fort William. ${ }^{4}$ Moreover, even if religion had not proved a bar to economy, concern with status would have been. It had long been a tradition with the senior members of the European Companies to imitate Mughal grandees in the parade of servants. 5 Thus a member of the Fort William Council never appeared in

1. Mrs.Fay, op.cit.,p.186; Williamson, op.cit.,pp.182-3.

2. Mrs.Kindersley, op.cit.,p.288; Williamson, op.cit. pp.301-2.

3. Sinha, op.cit., p.22.

4. Ibid., p.189.

5. See Ch.VI in K.M.Mohsin's London Ph.D. thesis (1966) on A Study of Murshidabad District, 1765-93, for the number of servants in the Nawab's household. 
the street with a train of less than twenty fellows or walked from one room to another in his house unless preceeded by four silver-stick bearers. ${ }^{1}$ As an official made advances in his rank, his sircar urged him to increase the retinue of his servants. ${ }^{2}$ And so universal was the practice of mintaining a large number of servants by the senior officials in Bengal ${ }^{3}$ that a custom grew up to call then "Qui hies!" For whenever they needed attendance from their servants, they used to say, "Qui hy - who's there?"4 For the non-official class, it was likewise a question of social status. William Hicky, an adrocate at the Supreme Court, Calcutta, maintained at least sixty-three servants. 5

1. Mss.Eur.E.25, p.52. This custom was borrowed directly from high Muslim officials who moved out attended with chobdars or staff bearers. The word chob is from the Persian, meaning wood or a staff or club. Mrs.Kindersley gives an amusing derivation of the word chobdar, the man who impresses the mob with his master's dignity, saying that chob means silence (see p.286). She confuses chob with the word chup - Hindi for silence.

2. Mrs.Kindersley, op.cit., p.287.

3. Le Couteur, Letters from India, p.299.

4. Wallace, op.cit., p.126.

5. Dennis Kincaid, op.cit., p.82. 
For a lively description of how this army of servants was deployed we may turn to the journal of Alexander Mackrabie, ${ }^{1}$ meant for his father and friends, written in 1775 . He was at this time living with Francis, Livius and Collings at the former's great house. "Mày own Establishment", he writes, "consists of a Sircar, a Broker \& Interpreter, - a Jemmader who stands at my Door, receives messages, announces Visitors, and also runs by the side of my Palanquin to clear the way. This Varlet is a tall Man, with a most respectable Pair of whiskers and moreover wears a Dagger in his sash decorated with Gold Tassels. I am preceded in all my Peregrinations by two Peons or running Footmen and as many Hircarahs or Messengers. These Gentry being all furnished at the Expence of the Company as an appendage to my office of Sheriff, I am only on the Expence of a Kist-mugar, literally servants $/ \bar{s} i c\rangle$ of all work, but as mine proved to be a sérvant of no work I have just discharged him. Eight Bearers for my Palanquin complets $\langle\bar{s} i c\rangle$ my Train. I would Keep a Horse but positively I cannot afford it. Mr. F keeps five and according to the cursed fashion of this idle country, has ten fellows to look after them, besides a coachman to keep the whole in order. He has moreover twelve Palanquin Bearers, for no Reason that I can learn except his being a Councillor - four Peons, four Hircarahs, two Chubdars who carry silver staves, two Jemmadars. These are without Doors - Within, a Head Sircar, or Banyan or Broker or Agent, who sees that he is cheated in due form - who has his spies over everything that Master buys ... Housekeeping comprador and his mate go to market, two cooleys bring home what he buys - Consomar takes charge of it, Cook and two Mates dress it. Baker in the House. Butler \& his assistant take charge of Liquor,

1 . Mackrabie had been appointed Sheriff of Calcutta. 
Abdar and his Mate cool them. Two Side Board Men wait at Table. House - two Metrannees to clean it, two watchmen to guard it, - a Durwan to keep the Door. Taylor, Washerman and Ironing Man for each Person. Mashalgees Torch Bearers F 4, M 2, L 1, C 1. We make a flaming Funeral appearance. Two Mallies or Gardeners. Cow and Poultry feeder and Park Man... Let me see. Mr. F 62 One hundred and ten servants Mack 20 to wait upon a family of four L \& Col128 People. Oh monstrous! and $\overline{110}$ yet we are aeconomists. Tell want weeding." 1 me if this Land: does not

Mackrabie's picture is hot, however, a complete one. It does not include a hookah bardar, barber or hairdresser, dog-keeper or camel-driver as it might well have done. 2 There is no mention either of a boat crew, though since the river was the main communication in those days, many kept budgerows or pinnaces for business and recreation. 3 Moreover, since Mackrabie was a batchelor he has no female servants on his list, no ayahs or ladies' maids and no dais or nurses. 4

Mackrabie does not mention any European servants in his establishment. There were a few of these always

1. See Mss.Eur.E.25, pp.62-3.

2. See list of servants in Williamson, op.cit., p.185 et seq.

3. Ibid., p.283 et seq.; Infra, Ch.VI.

4. Ibid., p.185 et seq. 
in Calcutta: stewards, butlers, postillions, coachmen, and hairdressers, and their advertisements often appear in the contemporary gazettes. But they were very expensive - a coachman's wages were Rs.200/- a month, ${ }^{1}$ and Hickey's London hairdresser Freskine was paid Rs.100/a month, plus board and lodging, and permission to undertake ladies' hairdressing in his spare time ${ }^{2}$ and often required housing and servants of their own. Moreover they were in an advantageous position to ferret out the secrets of their masters ${ }^{3}$ and were liable to leave to set up an independent business in Calcutta. 4 Maids brøught out by English women also showed a discouraging readiness to desert their mistresses on reaching Bengal to go off and get married. 5

For these reasons the Europeans in Bengal generally

1. Williamson, op.cit., p.334.

2. Hickej, op.cit., vol.3, p.153.

3. Williamson, op.cit., p.334-5.

4. For example, the well-known Harmonic Tavern was founded by Edward Creighton, late cook to Thomas Rumbold, Governor of Madras and John Nicolls, late steward to Elijah Impey, Chief Iustice of the Supreme Court, Calcutta, on the south east side of China Bazar. Bengal Gazette, 4 February 1780 , quoted in the Journal of the Calcutta Historical Society, 1931, vo1. $42, \mathrm{p} .74$.

5. Williamson, op.cit., pp.335-7. 
preferred Indian servants. These were described as remarkably clean in their dress and graceful in their motions. ${ }^{1}$ They were dressed in white muslin jackets, tied round the waist with green sashes and gartered at the knees in like manner with puckered sleeves as in England. They had white turbans bound by the same coloured ribbands ${ }^{2}$ and wore slippers on their feet. ${ }^{3}$ White muslin with sashes and turban ribbons varying from family to family thus formed "the family liveries of the East". 4

None of the servants ever ate, drank or slept in their masters' houses. ${ }^{5}$ But since there was no Black Town close at hand, 6 as at Madras, in Calcutta they were usually allowed to put up huts in the house compounds. 7 So the most elegant mansions were environed

1. An Cfficer, op.cit., p.91.

2. Goldborne, op.cit., pp.69-70.

3. An officer, op.cit.,

4. Goldborne, op.cit.

5. Ibid., p.68.

6. The Black Town at Calcutta was to the north of the European part of the city. In 1790 its population was computed at approximately six hundred thousand Indians, women and children included. See Grandpre, op.cit., vol.2, pp.5-6.

7. Capt.J.Price, Some Observations and Remarks on a late Fublication, p.61. 
with thatched mud huts, ${ }^{1}$ low and, in the absence of chimneys, grimed with smoke from cooking. ${ }^{2}$ Contemporary travellers' accounts are often filled with complaints against the way in which these servants' quarters spoiled the beauty of the European houses. ${ }^{3}$

In the late eighteenth century many of the Calcutta servants were people from the outlying areas of the Presidency, from Bihar and Orissa, landless labourers attracted by the handsome wages paid by the Europeans. Williamson thus notes that certain services such as that of palanquin bearer were monopolised by Oriyas until the arrival of other groups from Patna district. 4 Except for the sircar and a few others who did no menial duties, ${ }^{5}$ most sefvants were from up country, ${ }^{6}$ and once engaged they sought to provide for their sons and relatives by pressing their masters to keep more servants. Their 1. See Daniell, op.cit., Plate 1, View taken of the Esplanade, Calcutta.

2. Mrs.Kindersley, op.cit., p.277.

3. R.G.Wallace, an officer in the Indian Army from 1805, opined however that these huts added, by contrast, to the grandeur of the European houses. See p.65.

4. Williamson, op.cit., vol.1, p.303 et seq.

5. Ibid., p.185 et seq.

6. Ibid., p.212 et seq. 
Oriya and Bihari descendants are still living in the slums in and around Calcutta.

For the Europeans, servants provided two continuing headaches - wages and petty crime. The problem of wages was tackled, as it was by justices of the peace in England, ${ }^{1}$ by fixing wage rates. Thus in 1759 the Quorum of Zamindars, ${ }^{2}$ consisting of Richard Becher, William Frankland and John Zephaniah Holwell fixed monthly wage rates, varying from one to five rupees, for the various categories of servants. ${ }^{3}$ Wages continued to rise throughout our period, however, and new scales were issued in 1787. By 1801 they were almost treble the rates fixed by the Quorum of Zamindars in 1759,4 and there were loud complaints by the employer. "I am one of the many who can very ill afford to pay servants high wages, and I am very sorry that so much time pas passed and so little done," a correspondent wrote to the India Gazette in $1786 .^{5}$ By that date it was officially calculated 1. Basil Williams, The Whig Supremacy, pp.137-8, 183.

2. The office of Zamindar dates back to 1699 when the villages of Sutanuti and Govindapur forming the nucleus of Calcutta were leased by the Company from the Nawab of Bengal. Members of the Council were generally appointed Zamindars to discharge the duties of Zamindary.

3. Bengal Consultations, 21 May 1759. Long, op.cit., Sec.418, pp.181-4.

4. See Appendix V.

5. The India Gazette, Calcutta, 8 May, 1786, vol.6, No.286. 
that even a reasonably economical family could scarcely dpend less that Rs.250/- a month on servants' wages, 1 so that given the customary numbers of servants, the correspondent's complaint was understandable.

Because of the language difficulties, ${ }^{2}$ misunderstandings between masters and servants ${ }^{3}$ were even more frequent in Bengal than in England. And since there was a general belief that "we are Cheated in every Article, whether of the House, the Garden, the Stable or our own Private Expences", 4 there was much iml-treatment of servants. 5 One diarist in the India Gazette thus cheerfully acknowledged that he derived much pleasure from kicking and flogging his servants for trifles, according to the custom of the time. ${ }^{6}$ In 1785 one of the two Police Superintendents of Calcutta felt organised control was needed:

1. Bengal Public Consultations, 19 December 1785, quoted in Aspinal1, op.cit., p.39.

2. F.J.Shore, Notes on Indian Affairs, vol.2, p.319.

3. Hicky, op.cit., vol.3, pp.234-5.

4. Mss.Eur.E.25, p.89.

5. Bengal Consultations, 21 March 1763. Long, op.cit., Sec.644, p.311.

6. The India Gazette, Calcutta, 30 December 1780, No.7. 
"It is universally acknowledged," he wrote, "that almost all robberies are perpetrated by the aid and connivance of servants; ${ }^{1}$ I have therefore taken the liberty to propose that an office for the registration of all menial servants be established and added to the office of the Superintendents of the Police." 2

In April 1786 the British residents in Calcutta took up this suggestion and appointed a select Committee to frame regulations for the employment of Indian servants. The chief proposals of the Select Committee were: a register of servants should be compiled and while no unregistered servant should be given work, the registered servant could not be employed without a "chit" from his master. And if a servant succeeded in obtaining a new post without a testimonial, he would be sent to gaol, and if, after three weeks' imprisonment, he would be unable to procure one, he would be flogged and treated as vagabond. All servants should be paid standard wages. While Europenas paying higher wages than the scheduled rate should be fined, servants accepting them should be not only fined but also imprisoned. These regulations were to be enforced by an annually elected committee of

1. Robberies by non-official Europeans like sailors of merchant vessels were also frequent. See Calcutta Gazette, 3 November 1791. Seton-Karr, op.cit., vol.2, p.54.

2. Bengal Public Consultations, 21 March, 1785, quoted in Aspinall, op.cit., p.40. 
twenty-four Europeans; members who neglected to attend its meetings should be punished by the supreme court. ${ }^{\ddagger}$ Unfortunately, these proposals were of far too drastic and revolutionary a character to meet with universal approval. The report of the Committee was not unanimous the minority pointed out that the cure would be worse than the disease, and the matter was dropped eventually.'

In addition to free servants, European, Eurasian or Indian, slaves were also employed in some European households in Bengal. Slaves from Africa fetched some Rs.400/- on average in 1780 and they were therefore an expensive status symbol: ${ }^{2}$ this was the period when the little negro boy was fashionable in Europe. 3 Most Europeans, however, purchased the much cheaper Indian slaves from Sylhet, Dacca or Mymensing. Since slaves were

1. Beñgal Public Consultations, 13 August 1787, quoted in Aspinall, op.cit.,

2. A.K. Chattopadhyay, slavery in the Bengal Presidency..., London $\mathrm{Ph} . \mathrm{D}$. thesis, $1963, \mathrm{p} .78$ et seq. Stark vrites that in 1915 his friend Dr.Annandale told him that he had traced the presence of African blood in a fair percentage of the people of a particular type in Calcutta. Stark thinks that the one-time liberal importation of African slaves into Calcutta is a reasonable explanation of Annandale's discovery. See H.A.Stark, Calcutta in Slavery Days, p.3.

3. Dr.Plumb quotes an advertisement from the Liverpool Chronicle of 15 December 1768 to show that before 1772 Negroes were commonly bought and sold in England. See p.159. 
regarded as the property of their masters, they were much exposed to ill-treatment. If they ran away, they could by law he recaptured, and would be well flogged. Anyone who employed a runaway slave was liable to legal action by the owner. ${ }^{1}$ It is to be noted that in Bengal slaveswere mainly employed in domestic duties plantation slavery was unknown.

Finally, to minister to the needs of the European households there were the self-employed servants seamstresses, including girls trained in the Calcutta orphanages, dancing and music masters, and hairdressers. Since gentlemen still wore wigs and ladies put up their hair in elaborate styles, European hairdressers were to be found at work in Calcutta. Monsieur Lafleur charged four rupees for dressing a lady's hair, two rupees for a gentleman's, and six rupees for cutting. 2 Monsieur Siret charged ladies eight rupees for cutting and four rupees for hair dressing, and half these amounts to a gentleman. ${ }^{3}$ Most extravagant of all, Monsieur Malver took no less than two gold mohurs for dressing a lady's

1. Chattopadyay, op.cit.

2. Calcutta Gazette, 30 0ctober 1788; Seton-Karr, op.cit. vol.1, p.289.

3. Calcutta Gazette, 9 October 1788. Ibid., p.288. 
hair, ${ }^{1}$ doubtless in the finest continental style. Despite the damp and heat of Bengal, ladies dressed their hair into pyramids of gauze, powder, feathers and pomatum according to all the astounding fashions of London. 2 These structures were then topped with head-dresses of white muslins, and with fancy bandeaux, coloured, gilded or embroidered to match their sashes and stomachers, 3 a curious echo of the servants' livery of cummerbund and turban ribbon. The difficulty ${ }^{4}$ of strictly following the movement of fashion in England allowed both men and women much latitude to their personal taste and fancy. Miss Charlotte clavering, one of the general's daughters was praised by Margaret Fowke: "The shape of her headdress and the dress of her person were so well as would bear to be represented/the most elegant painting." 5 But freedom

1. Calcutta Gazette, I Dec.1785. Ibid.p.119. 1 gold mohur 16 sicca rupees. See Yule \& Burnell, oplcit.,pp.573-4.

2. Miss Moore to Miss Fowke, no date, Mss.Eur.E.9, Fowke Mss.K.30, p.78; Busteed, op.cit., p.146.

3. The World, Calcutta, 28 April, 1792, vol.1, No.19.

4. Cr."J'ai trouvé la toille bien jolie et c'estoit le prix le plus medicore, que j'ai pu trouver apres avoir ete dans toute les boutiques de Calcutta.' C.H.von Danckelman to Mrgaret Fowke," 13 February 1785. Mss.Eur.E.5, Fowke Mss.K.26, p.187.

5. Miss Fowke to Mrs Strachey, 16 February 1778, Mss.Eur.D.10, Fowke Mss.K.23, p.15-6. 
of taste also had its pitfalls. Miss Fowke thus reported on her partner, Mr. Noofar, at a ball presided over by Mr. Evans as master of ceremonies:

"I confess my gravity was almost discomposed at seeing his hair tied in an immense bow behind \& his toupee nearly as high as my own - I wondered which way his hat would be secure \& indeed when $i$ t was on it looked like a lady's riding hat." 1

If halrdressers could drive a profitable husiness in Calcutta, so could tailors. Long records that a tailor named Martin, who came out on the Indiaman Lord Clive in 1763, found his business so profitable that he refused to exchange it for a post in the Company's service, and at the end of ten years was able to give his friends a spendid dinner and return to Europe with a fortune of two lakhs. ${ }^{2}$ What sort of work he did may be imagined from Hickey's description of the clothes he had made for the celebration of the King's birthday:

"...a coat of pea green lined with white silk and richly ornamented with a spangled and foiled lace, waistcoat and breeches decorated in like manner being also of white silk." 3

The inventories of the Mayor's Court and Supreme Court,

1. Miss Fowke to Miss Clavering, 23 April 1778. Mss.Eur.D.10, p.11.

2. Rev.J.Long, "Calcutta in the Olden Times" in Smith, op.cit., vol.8, p.279.

3. Hicker, op.cit., vol.2, p.173. 
and the advertisements of stocks of dresses newly arrived from Europe show that Hickey was not alone in his taste for rich dress: the Europeans attired themselves with a magnificence to match their great houses and armies of servants. This would be in addition, of course, to the huge stock of linen, shirts and underclothes, which every European needed for the sultry weather in Bengal, when they had to change several times a day. ${ }^{1}$ Many doubtless were cotton, the more wealthy wore linen, preferably Irish. ${ }^{2}$ costly and extravagant dress was the aristocratic fashion at home, 3 and both men and women in Calcutta were ready to follow the fashion as far as they could.

1. Calcutta Gazette, 27 May 1790, quoted in Hilton Brown, The Sahibs, pp.196-7.

2. A Young Civilian in Benga1, 1805, in The Journal of the Calcutta Historical Society, op;cit.,p.116.

3. On special occasions men wore dress which cost as mach as 500 guineas and a waistcoat might alone cost 50 guineas. See A.S.Turberville, English Men and Manners in the Eighteenth Century, p.95. Again, upper class ladies decorated their dresses with jewels, sometimes worth $£ 50,000$, as had been actually done by a certain Lady Villars in a famous masquerade given by the Savoir Vivre Club at the Pantheon in 1775. See Talbozt Hughes, "Castume" in Johnson's England (edited by A.S.Turberville), vol.1, p.403. 
Every new arrival from London might be expected to bring something new. In 1783, Mrs Hastings provided matter for comment, by appearing, sashes and shift, in a dress called "Chemise a la Reine", the latest fashion in England according to the friend who supplied her with the news, ${ }^{1}$ "the whim of the moment" according to the gossips of Calcutta. 2 Mrs Wheler, wife of Edward Wheeler, the one-time Director, and one of the fashionable ladies of London Society was shocked, however, to see the dresses in Calcutta, and complained that she had not seen "one well-dressed woman" since her arrival there. ${ }^{3}$ (A Dutchman, colning out on the Thetis in 1793-4. was equally shocked because the dresses on board really were in fashion - he decided from the style that all the wearers must be pregnant. $)^{4}$

The effort to keep abreast of European fashion bore hardly on the men. An old military captain, who had come out to Calcutta in $1736 \mathrm{might}$ write to the India Gazette:

1. S.C.Grier, editor, Letters of Warren Hastings to his Wife, $p .30$.

2. Mrs.Fay, op.cit., p.174.

3. Miss Fowke to Mrs. Strachey, 16 February 1778, Mss.Eur.D.10, p.16.

4. Hickey, op.cit., vol.4, pp.114-5. 
"I am hurt whenever I venture into a large company, to see the fashions so sadly changed. My holiday suit consisting of a flowered Velvet coat, of the Carpet pattern, with two rows of broad Gold Lace, a rich King cob.Waistcoat and crimson Velvet Breeches, with Gold Garters is now a butt to the shafts of Macaronies' 1 ridicule." 2

But there must have been many husbands, as Sophia Goldborne put it, who turned pale on hearing that their wives were visiting the "Europe Shops" at Calcutta, determined to be in fashion. One such visit could cost thirty or forty thousand rupees in dresses and ornaments, $^{3}$ for their policy of take now and pay later was a great encouragement to extravagance and debt. 4 Despite the presence of European tailors in Calcutta, ladies' dresses were regularly imported from Europe, and the wives of senior officials, with their high salaries, spent more on dress than those in comparable positions in England. 5 Dorothy Shaw, giving an account

1. In England about 1772 Charles Fox and his followers who set the fashion for men's extravagant dress in London were known as macaronies. See Mary Bateson "Social Life, 1742-84" in Social England (edited by H.D.Trail and J.S.Mann), vol.5, p.479.

2. The India Gazette, Calcutta, 24 Feb.1781, No.15.

3. Goldborne, op.cit., vol.1, pp.88-9.

4. A Young Civilian in Bengal, 1805, in the Journal of the Calcutta Historical Society, op.cit., p.118.

5. J.W.Kaye, "The English in India", Calcutta Review, vol.1, 1844, p.31. 
of Warren Hastings's wedding speaks of all the ladies present as dressed in coloured and embroidered gowns with caps full of diamonds and pearls, ${ }^{1}$ and stavorinus paints a similar picture of the ladies with great hooped petticoats and wearing "immense quantities of jewe1s". 2

In the elaborateness of their dress, the Europeans might imitate London or Paris, ${ }^{3}$ on formal occasions. But in the early years of our period, as had been the case since the early seventeenth century, for informal wear the adopted Indian dress. At home banyan shirts and

1. She adds, of Miss Touchet, "tho' not decked with jewels, her personal charms made up for it", a pretty compliment to Miss Touchet and reflection on the rest. Shaw to Miss Fowke, 22 August 1777. Mss.Eur.E.9, Fowke Mss.K.30, p.276.

2. Stavorinus, op.cit., vol.1, p.147. Ladies often bequeathed their jewels to their relatives as Pouonah Nattonss did by her will of $7 \mathrm{July}$ 1771: "I give and bequeath to my brought up Girl named Anlie, viz., One pair of gold Bracelet, Four pr. Gold Earrings of Kinds, five strings of small pearls, sixty Pearls in one small string, Three Gold Rings stone mounted. Two Europe Rings stone mounted... to my Nice Maria Nattonss one Diamond Ring, one Pair sleeve Diamond Buttons, one Hold hairpin." See Will of Pouonah Nattonss, Filed 15 May 1772. B.W., Range 154, vol.55, pp.21-2.

3. London fashion was remarkably influenced after the Peace of Aix-la-Chapelle in 1748, when travelling on the Continent once tiore became possible. See T.Hughes "Costume" in Turberville, op.cit., p.386. 
loose trousers (pyjamas) were worn for coolness and comfort. ${ }^{l}$ Even for their evening visiting concessions were made to the climate of Bengal. The old residents of the Presidency usually dispensed with their heavy coats, wearing instead waistcoats and jackets of white cotton. It was the newly arrived official and the army officer, especially of a royal regiment, who clung to his coat and so underwent a kind of "warm bath", of the most distressing description to themselves and to their neighbours. 2 Then a man left home to dine with a friend he would wear a white jacket; when going to a formal party he would set off in a coat, carrying a white jacket with him or sending it ahead with a servant, and on arrival his host would immediately invite him to discard the coat and substitute the jacket. ${ }^{3}$ At official parties at Government House, the first words uttered by Cornwallis to his guests after taking his seat, were, "off Coats!" 4

1. A Young Civilian in Bengal, 1805 in the Journal of the Calcutta Historical Society, op.cit., p.116. Banyan shirts and loose trousers spread to England through the returned English nabobs during the period under review. Spear, op.cit., p.147.

2. Williamson, op.cit., vol.2, p.115.

3. J.W.Kaye, "The English in India", Calcutta Review, op.cit., p.32.

4. Cotton, op.cit., pp.155-6. 
Towards the end of the eighteenth century, and especially when Lord Wellesley imported a grander tone to Calcutta society, the practice of modifying dress to suit the sultry climate was abandoned. Jackets began to be considered too informal for public and even for private occasions. English black broadcloth and full. dress came into favour, ${ }^{1}$ even for crowded assemblies and large dinner parties where the heat was more than usually intense. Kaye records his lively recollection of the oppressive heat at a large dinner party where the only gentleman who had the good sense to discard his uniform in favour of white trousers was the GovernorGeneral, Charles Metcalfe. ${ }^{2}$ It was fortunate that the change to a more formal dress coincided with the general introduction of punkahs and tatties - indeed it may have been theirititroducition which made possible the change. In their dress the English in Bengal, most notably in Calcutta, moved away from a healthy simplicity and lightness, such as the climate dictated. Here the influence of the greater numbers of new arrivals, especially of army officers of royal regiments may perhaps be traced. 1. Valentia, op.cit., vol.1, p.196. 2. J.W.Kaye, "The English in India", Calcutta Review, op.cit 
In diet, too, a similar change is visible, at least until the last decades of the century,

Until late in the century the three meals taken were breakfast, dinner and supper, but as dinner was gradually shifted from noon until the evening, these were replaced by breakfast, tiffin and dinner. ${ }^{1}$ The hours at which they were taken varied with the season for by 1754 in the Company's offices the hours of work were $9 . \mathrm{a} . \mathrm{m}$. to $12 \mathrm{a} . \mathrm{m}$. in the hot season, ${ }^{2} 10 \mathrm{a.m}$. to $1.30 \mathrm{p} . \mathrm{m}$. in the cold, ${ }^{3}$ together with a provision for work in the afternoon ${ }^{4}$ during the despatch of a ship from Bengal or the arrival of one from England ${ }^{5}$ or during an emergency such as the war with Mirkasim in 1763,6 and doubtless similar hours were worked by merchants and other non-officials. 7 They doubtless also varied with seniority - Mackrabie took his breakfast at $8.0 \mathrm{a.m.} .^{8}$, some senior officials as late as 10 a.m.)

1. Victor Jacquemont, Voyage dans I'Inde, Vol.1,p.205.

2. Bengal consultations, 22 August 1754, Long, op.cit., Bec. 140, p.53.

3. Busteed, op.cit., p.121.

4. Bengal Consultations, 22 August,1754, Long - op.cit.

5. Mss. Eur. E.25, p.109.

6. Misra, op.cit., pp. 65-6.

7. From the period of working hours the impression seems to be of an easy going life. For an interesting account of how a senior English official might pass his day in the $1770^{\prime} \mathrm{s}$, see Appendix VI.

8. Mss. Put. R. 25, p.63 
Breakfast had originally been a light meal Mackintish, visiting Calcutta in the 1770's, states that it consisted only of tea and a plate of bread or toast. ${ }^{1}$ Towards the end of the century, however, when the main meal, dinner, was shifted to the evening brealkfasts seem to have become more substantial. Wallace writes that to tea or coffee and light accompaniments had now been added highly spiced meat, fish and fowl, with many varieties of fruit and preserved, ices and jellies in profusion, ${ }^{2}$ while Williamson, more exhaustive in his description adds rice, kitchery (a kind of olio) and the various sweetmeats prepared in Bengal. 3 Mrs Fay excuses this heavier eating by saying that it was believed that the appetite was greater before the heat of the day, and so a heavy meal was welcomê. ${ }^{4}$

The dinner hour was gradually shifted from 2 p.m. to $7 \mathrm{p.m.}$, and this move of the main meal to the evening brought English into line with Indian habits. Nevertheless it would seem that the change was in reality made in

1. See Appendix VI.

2. Wallace, op.cit., pp.124-5.

3. Williamson, op.cit., vol.2, p.128.

4. Mrs.Fay, op.cit., p.181. 
imitation of the aristocratic society of England which in the last decades of the century had moved the dinner hour from two or three in the afternoon to five o'clock or later. ${ }^{1}$ In this, as in so many other matters it was the aristocratic pattern of life in London which was followed in Calcutta.

The tiffin which replaced the mid-day dinner, ${ }^{2}$ described by Williamson as "a little avant-dinner" might consists of grilled fowl, mutton chops, cold meats, or curry and rice, taken at one or two o'clock. ${ }^{3}$ It was followed in the early evening by dinner, the most formal and the heaviest meal of the day. Sophia Goldborne describes the setting: the table covered with snow-white damask table cloth of the finest texture, each plate flanked with two glasses, one tall and slender like the English hob-nob glasses, for "lall shrub", 4 the other for any kind of drink, and with a folded damask

1. E.N.Williams, op.cit., p.46.

2. Valentia, op.cit., p.195.

3. Williamson, op.cit., p.111.

4. Lall shrub = Lal shariab i.e. Red wine. 
napkin, with a decanter of water, ${ }^{1}$ and a tumbler for diluting the wine. ${ }^{2}$ Mrs. Fay describes the food:

"A soup, a roast fowl, curry and rice, 3 a mutton pie, a fore-quarter of lamb, a rice pudding, tarts, very good cheese, fresh churned butter, fine bread, excellent Madeira (that is expensive but eatables are very cheap)."

Elsewhere she adds:

"People here are mighty fond of grills, and stews, which they season themselves and generally make very hot. The Burdwan stew takes a great deal of time; it is composed of everything at table, fish, flesh and fowl; - somewhat like the Spanish 01la Podrida, - Many suppose that unless prepared in a silver saucepan it can not be good." 5

Supper was at ten o'clock or later. It had been fairly substantial while dinner was still taken early,

1. The city's supply of water for drinking and other purposes came from the tank dug by the order of government in the middle of Calcutta. It was enclosed by a breast-high wall with a railing on the top. The pond is now known as Lal Dighee because of the reflection in its water of the red colour of the Missionary Church, built by Kiernander, in 1770 . See Grant, An Ang10-Indian Domestic Sketch, p.63; Grandpre, op.cit., vol.1, p.2; Hart, op.cit., p.9.

2. Goldborne, op.cit., vol.1, pp.60-1.

3. The returned tinglish nabobs made curry and rice popular in England. By 1784 curry and rice had become special items of many restaurants in Piccadilly, London, Holzman, op.cit., p.90.

4. Mrs. Fay, op.cit., p.181.

5. Ibid., p.189. 
and while the round of evening visits was still in fashion, supper rounded off the social calls. ${ }^{1}$ Mrs Fay relates that if a host asked his visitor to put down his hat this was taken as an invitation to supper. ${ }^{2}$ When dinner was shifted to the evening, and social calling was transferred to the morning, ${ }^{3}$ supper became no more than a snack - a glass or two of light wine taken with cheese. 4 It was as well that it was light, for whereas at the beginning of the period under review Europeans had taken only one reqlly heavy meal, dinner, by the end they were taking three - breakfast, tiffin and dinner.

Such heavy eating was the easier to indulge in because prices in Bengal were low. In 1780 Mrs Fay gave the price of a sheep as two rupees, while the following could be had for a rupee: a lamb, six good fowls or ducks, twelve pigeons, twelve pounds of bread, two pounds of butter and a joint of veal..$^{5}$ In 1810 Williamson

1. Mss.Eur.E.25, p.105.

2. Mrs. Fay, op.cit., p.190.

3. Williamson, op.cit., vol.2, pp.110-1.

4. Ibid., pp.115-6.

5. Mrs. Fay, op.cit., pp.181-2. 
recollects that twenty-nine years back when he was marching from Berhampur to Cawnpur, with a detachment of European recruits, six sheep were purchased for a rupee, which in British currency, would be fivepence each. 1 Many Europeans also kept poultry and turkeys, though the latter were hard to rear in the climate of Bengal, and had a piggery where they carefully bred and fattened pigs for their tables. 2 In Calcutta, too, it was possible to add articles of European diet, and though the prices of Bengal foodstuffs tended to rise in the early nineteenth century, those from Europe fell. 3 Up country the fare must have been less varied, and Tennant suggests that it was only in the last decades of the eighteenth century that regular supplies of meat and poultry were available in cantonments. 4

Late eighteenth century England was noted for heavy eating and devotion to the pleasures of the table. As Dorothy Marshall puts it, this explains "the broad and comfortable faces so often seen in eighteenth century portraits".5 Even so, the newcomer from England could

1. Williamson, op.cit., vol.1, p.293.

2. Spear, op.cit., p.51.

3. J.W.Kaye, "The English in India", in Calcutta Review, op.cit., p.35.

4. Tennant, op.cit., vol.1, p.330.

5. Dorothy Marshal1, "Manners, Meals and Domestic Pastimes" Turberville, op.cit.,p.347. 
still be astonished at the grossness of both men and women's appetites in Bengal: one such person who concealed his real name under a pseudonym of Quiz was shocked to see one of the prettient girls in $\mathrm{C}_{a}$ lcutta eating some two pounds of mutton chops at one sitting, and officers and men in barracks cramming themselves voraciously on curry, rice, beef and goat. ${ }^{1}$ The English in Bengal not only ate heavily of beef and pork, which the ancient legislators of India had forbidden as both harmful in a tropical climate, but added to these English dishes, a variety of curries and highly spiced dishes. ${ }^{2}$

Almost any private diary, journal or letters of the day provides complaints of constant stomach troubles - but they are blamed upon the climate of Bengal rather than upon a diet totally unsuitable in content and quantity.

"I am tormented with the bile and obliged to live on mutton chop and water," writes Philip Francis, "the Devil is in the climate I think." 3

Warnings gradually made themselves heard, as in the newspaper which cited the case of the surgeon of an Indiaman who fell dead after eating a hearty dinner of

1. Kincaid, op.cit., pp.86-7.

2. C.Niebuhr, Voyage en Arabie..., vol.2, p.3.

3. Francis to Godfrey, March, 1775. Mss.Eur.E.15, p.66. 
beef, the thermometer standing at $98^{\circ},,^{1}$ It was not until the very end of the century, however, that a more temperate diet was adopted.

Over-indulgence in food was matched by overindulgence in drink, arrack for the lower class, wines and spirits for the upper class Europenns. The indigenous toddy and arrack, cheap as well as potent, had been accepted by the servants of the Company, as by the Dutch in Batavia, ever since their arrival in Asia. Arrack was the basis for punch, to which were added lime juice, rosewater, sugar and water, or it was taken neat. It was distilled sometimes from rice, sometimes from toddy, or palm juice, sometimes from unrefined sugar, flavoured with the bark of the babul tree to make jagre arrack, "hot as brandy and drunk in. drams by Europeans". ${ }^{2}$ It was by the eighteenth century, particularly the drink, the destruction, of the Company's troops and sailors. In 1757 Clive found it necessary to encamp a mile north of Chandernagore after he had captured the city from the French, because he feared the

1. Quoted in Iong, Peeps into the Social Life at Calcutta, p. 10 .

2. F. Ovington, A Voyage to Surat in the Year 1689. pp. 237-8. 
effect on his troops of the arrack to be got there. 1 In 1760 steps were taken to prevent the unlimited distilling and vending of arrack in Calcutta, ${ }^{2}$ but fifteen years later Mackrabie found the city still swarming with arrack sellers "to the ruin of the health and morals of the lower class of people". 3

Arrack and the heavy Shiraj wines from Persia had been drunk both by Mughal and by Company officials, but by the mid-eighteenth century the interruption of communications with Persia caused by Nadir Shah's invasions, by the political troubles of the Kajar dynasty and of the Durranis made the trade with Shirajincreasingly difficult. 4 The Company therefore took to shipping madeira to its settlements, finding this a profitable monopoly trade, for the pipe of madeira which cost $£ 25$ to $£ 30$ in Madeira was sold for £70 in Bengal. 5 One or two ships called annually at Teneriffe to take on Vidonia wine in like manner. 6 These were then distributed 1. Letters to Court, 16 April 1757, para.2, Long, op.cit. Sec.229, p.91.

2. Bengal Consultations, $31 \mathrm{July}$ 1760, Long, op.cit., Sec.469, p.218.

3. Mss.Eur.E.25, p.94.

4. Spear, op.cit., P.19.

5. Williamson, op.cit., vol.2, pp.118-9.

6. Sinha, op.cit, pp.40-1. 
among the Company's servants to a pattern which may be gleaned from the Proceedings of 29 september 1766. In that year the whole consignment of madeira by the Britannia was 125 pipes, ${ }^{1}$ from which thirteen were deducted for breakage and four reserved for the West Coast. The remaining 108 pipes, supplemented with $6 \frac{1}{3}$ pipes in godown from the previous year's consignment, was distributed as follows:

5 pipes to the Governor, 2 pipes to the second in Council and 2 to General Carnac, 1 each to the other Councillors, the Residents at Malda, Burdwan and Midnapur and to the two colonels in charge of brigades, $\frac{1}{2}$ a pipe each to the three lieutenant colonels, the two chaplains, eleven majors, fifteen senior merchants and the chief engineer, $\frac{1}{3}$ of a pipe each to sixty captains, eight factors and five surgeons, and $1 / 6$ of a pipe each to eighty-five writers and two hundred subalterns. 2

At 4,200 bottles for the Governor and 130 bottles even for the most junior writers and subalterns, the Company might seem to have made very reasonable provision for its

1. A pipe $=105$ gallons $=840$ pints or bottles.

2. Long, op.cit., Sec.871, p.457. 
servants. 1 However additional supplies of madeira were also imported as a private speculation, ${ }^{2}$ and a variety of other wines as we11. The senior servants of the Company arranged for their agents to send out a regular supply of wines, and ships' officers brought out further supplies for sale. Thus in 1775 Mackaabie informed George Stainforth that the wines Francis had brought out had proved excellent, and asked for a regular further supply of claret, hock and Kenton's porter, to the extent the tonnage allowed to Francis by the Company would permit. 3 The order would seem necessary for in one month in 1774 Francis's wine book shows that 268 bottles of wine had been

1. Madeira travels well, and was supposed to be improved by the voyage round the Cape; it was often shipped back to England as a present to friends there. See C.Cockerell to F.Fowke, 21 March 1786. Mss.Eur.E.7, p.789.

2. In 1783 there was a glut of madeira at Calcutta and a ship's captain, "a wily Scotchman" as Hicky calls him who brought out 150 pipes found no customers. Hickey, op.cit., vol.3, pp.215-6. The ship's captains were also engaged in other speculations such as importation of European furniture, clothing, shoes, hats, millinery and toilet articles, hams, preserves and pickles, for sale at Calcutta. See J.K.Stanford, editor, Ladies in the Sun, p.30.

3. Mackrabie to Stainforth, 25 March 1775. Mss.Eur. L.25. pp.71-2. The allowance of shipping space given by the Company varied from $3 \frac{1}{2}$ to $1 \frac{1}{2}$ tons. In 1808 the maximum amount was raised to 5 tons in the case of individuals of the highest rank. See Parkinson, op.cit., pp.273-4. 
drunk in his household - 99 bottles of claret, 75 bottles of madeira, 74 bottles of porter, 16 bottles of rum, 3 bottles of brandy and 1 bottle of cherry brandy. The list for November 1774 also included gin and hock. 1 Ten years later the following wines were advertised for sale in Calcutta:

\begin{tabular}{|c|c|c|c|c|c|c|}
\hline $\mathbf{A}$ & dozen & bottles & s of & hock & Sicca Rs. & 50 \\
\hline$"$ & $"$ & $"$ & $"$ & French burgundy & $"$ & 30 \\
\hline " & " & $"$ & $"$ & Jamaica rum & $"$ & 25 \\
\hline$"$ & $"$ & $"$ & $"$ & cognac brandy & $"$ & 32 \\
\hline$"$ & " & $"$ & $"$ & English claret & $"$ & 24 \\
\hline A & case & (of $15 \mathrm{~b}$ & oott 1 & les) of Holland gin & $"$ & 30 \\
\hline $\mathbf{A}$ & cask & of Londor & & rter & $"$ & $100^{2}$ \\
\hline
\end{tabular}

In 1805 Henry Roberdau calculated that if a gentleman was hospitable, claret alone would cost him sicca Rs. 400/- per month or exactly $\$ 600$ per annum. ${ }^{3}$

clearly the habit of heavy drinking had scarcely declined during our period, while its cost had gone up as cheap Indian spirits were replaced by imported European

1. Mss.Eur.E.24, Francis Mss.K.67, p.6.

2. Calcutta Gazette, 8 April and 27 May, 1784. Seton-Karr, op.cit., vol.1, pp.38-9, 44.

3. A Young Civilian in Bengal, 1805, in The Journal of the Calcutta Historical Society, op.cit., p.120. 
wines, beer and spirits. Miss Goldborne estimated

that ladies drank a bottle a day, and men four times as much, ${ }^{1}$ mainly after dinner when the ladies had withdrawn.

A gentleman would commonly despatch his three bottles of claret or two of white wine, celebrating his prowess by piling the empties as a trophy on the table. ${ }^{2}$ The Rev. Tennant comments that the gentlemen too often would finish "the whole chest of claret" while judging its quality at the dinner table. 3

In this heavy drinking, especially after dinner, the Europeans in Bengal were merely following upper-class habits in England. In eighteenth century England "Drunk as a lord" was more statement than proverb. When Northington became Lord Chancellor, he persuaded George III to abandon the evening sessions of Chancery on Wednesdays

1. Goldborne, op.cit., vol.2, p.69.

2. Ibid., vol.1, pp.63-4.

3. Tennant, op.cit., vol.1, p.77. There were two kinds of claret - one English bottled by the English wine merchants and the other Danish bottled by the Danish wine merchants. Because of the fear that prevailed among the people at Calcutta of the Danish wine merchants fining their wine with arsenic and sugar of lead, English clarent, though costly, was preferred to Danish which was cheap but had a good taste. Hickey, op.cit., vol.3, pp.204-6. 
and Fridays, so that he could finish his bottle of port after dinner. ${ }^{1}$ Charles Fox and Chatham set a similar example of hard drinking, which seems in fact to have been common to all classes in English society. ${ }^{2}$ As De Saussure commented, it was surprising that when Englishmen made such excessive use of water in the cause of cleanliness they should have drunk so little of it 3 The same might have been said of the Englishmen in Bengal who could have turned to nimboe pani or lemonade and other such drinks, ${ }^{4}$ or as in England to tea and coffee, but chose instead to slake the thirst caused by Bengal's hot weather in wine, beer or spirits, at great cost to their purse and health. The best excuse was that in Calcutta and other towns, the public tanks from which drinking water was drawn were often polluted, and that as in England ${ }^{5}$ wine was believed to have a medicinal value. In 1777 Hickeywas advised by his doctors 1. Williams, op.cit., p.46.

2. Trevelyan, op.cit., p.199.

3. Dorothy Marsha11, "Manners, Meals and Domestic Pastimes in Turbervilie, op.cit., p.350.

4. Williamson, op.cit., vol.2, p.123; Calcutta Gazette, 4 April 1816, quoted in Brown, op.cit., p.60.

5. Dorothy Marshal1, "Manners....Pastimes" in Turberville, op.cit., p.352. 
to drink as much claret as he pleased when he was stricken with cholera, ${ }^{1}$ and Sir John Royds ascribed his recovery, when given up for dead by the doctore, to a similar use of claret. ${ }^{2}$ If in those days few knew that "violent inflamation of the liver" was connected with heavy drinking, ${ }^{3}$ fewer still thought of acting upon this knowledge: certainly Hickey, ${ }^{4}$ Mackrabie ${ }^{5}$ and many others in Bengal did not do so. Nevertheless in the closing years of the century, in Bengal as in England there was some reduction in the amount of hard drinking, though not, as spear points out, among the military in their cantonments. Just as people were learning to be more temperate in the mealtimes, so they became more moderate in the matter of drinking. 6

1. Hickey, op.cit., Vol.2, p.131.

2. Ibid., vol.4, p.267.

3. Asiaticus (Stanhope), op.cit., p.136

4. HickeX, op.cit., vol.2, p.130.

5. Mss.Eur.E.25, p.102.

6. Hickey did not reform - in 1797 he was to be found drinking two and twenty bumpers at Colonel Sherbrooke's party. See Hickê,, op.cit., vel. IV, pp.190-1. 
Against all the efforts of their servants in India to imitate the aristocracy at home, in theirhousing, their numbers of servants, their expenditure on dress, on food and wine, the Directors of the Company, as sober merchants, set their face. In 1758 theycomplained to their Governor in Bengal of the expenses about cook-rooms,anc gardens latterly observed in the face of the bills received from thence, and issued instructions that the junior servants should not use palanquins, horse or chaise. 1 Nine years later, in March 1767 these instructions were repeated, not only with some additions - that the junior servants should not keep more than two servants and a cook, should not wear expensive clothes or indulge in garden houses - but with great concern and surprise at the expensive manner in which junior servants were living:

"The friends and relations of many of them complain to us of the large draughts made on them; those who have not such resources must run in debt to the Banians, the consequence of which will be that they will never be the free master of their own actions, and liable to be tempted to infidelity in the offices they are tnusted with to extricate themselves from the difficulties in which their extravagancies involve them." 2

1. Despatches to Bengal, 3 March 1758, Paras. 132-3. Long, op.cit., Sec.309, pp.129-30.

2. Sinha, op.cit., p.22. 
Next year it was the expenditure of Colonel Smith which drew down their disapproval, expenditure arising "from mistaken notions of a necessity of imitating the grandeur and ostentation of the Eastern Princes which is by no means our wish and intention, peing persuaded European plainness and simplicity will create more awe and respect than an imitation of their manners". 1 In 1769 there was again complaint from the Directors of "a great increase in all the articles which relate to parade and ostentation". But for all these annual exhortations to plain living, in Bengal the pattern of extravagance continued ${ }^{3}$ - often defended by those on the spot, as when in December 1767 they reported the use of palanquins to be absolutely necessary for the preservation of health in the climate of Bengal. 4 Early in the same year on 19 February, they had already written:

1. Sinha, op.cit., p.101.

2. Ibid., p.189.

3. The Court's orders were often violated with good humour. Thus at Madras, where restrictions were more severe than at Calcutta, an order was issued against the use of umbrellas. These umbrellas, or parasols, were called roundels from their shape. As the order was against roundels, the young writers had their umbrel las made square, declaring that there was nothing in the orders against squadrels. Kaye, op.cit., p.61.

4. Letters to Court, 10 December 1767, para.57. Long, op.cit., Sec.937, p.490. 
"The state of the Army is ... an object worthy of your consideration. In times of profound peace when the troops lose the advantages they enjoy in the field, and are reduced in cantonments to half batta, and in garrison to their mere pay, it is scarce possible that subaltern officers can subsist and maintain the appearance, which they ought, of gentlemen." 1

In 1768 Rennell reported that he had been mistaken in writing a few years earlier that $\$ 400$ a year would cover his expenses - last year they had come to $\$ 800 .^{2}$ In 1772, having advanced in rank, he put the sum necessary "to keep a handsome table, a sufficient number of servants and a carriage" at not less than $£ 1,000$ a year. 3 In the same year Clive declared in the Commons that a Councillor whose salary was scarcely $\$ 300$ could not live in Bengal for less than $£, 000$, and the same proportion held for other ranks. ${ }^{4}$ Cornwallis in 1788 minuted:

"I do not believe it possible for a man who keeps a house on a decent footing and on the lowest scale of economy, to be at an expense of less than one hundred and twenty pounds per annum for servants, and this sum with all others will unavoidably augment in proportion to his rank." 5

1. Sinha, op.cit., p.292.

2. Rennell to Burrington, 1 July 1768, H.M., Vol.765, p.18

3. Rennell to Burrington, 7 September 1772, Ibid., p. 243.

4. Debate in the Commons on the East India Judicature Bill

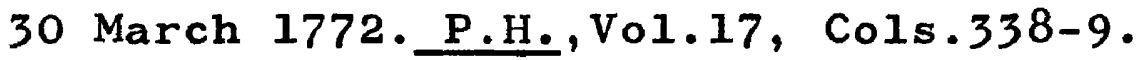

5. Quoted in Aspina11, op.cit., p.38. 
In 1796-7 the Rev. Tennant from several years' experience of Bengal declared that a family practising every economy would require from $£ 3,000$ to $£ 5,000$ a year, or double that if the family wished to join in the fashionable social life of Galcutta. ${ }^{1}$ At the turn of the century Williamson estimated as we have already seen in the previous chapter, that a single European, official or non-official, without participating in social life required at least $£ 600$ a year for his subsistence.

As the Directors feared, their junior servants, civilian and military, whose annual salaries were scarcely equal to a month's rent in Calcutta, ${ }^{2}$ met the situation by borrowing from the sircar or

1. Tennant, op.cit., vol.1, pp.63-4.

2. William Bolts, Consideration on Indian Affairs, p.85. 
banyan. 1 The latter was ready to advance money in the expectation that he could secure interest at the rate of 12 per cent a year, and with openings in private trade, revenue farming and the like as the borrower rose in the service. In the early years of our period successful private trade might bring salvation, as it did to Robert Lindsay, who, having borrowed from a sircar on arrival in Calcutta, ${ }^{2}$ was able by a successful speculation in salt

1. During the debate on the East India Judicature Bill on 30 March 1772, Lord Clive informed the House of Commons how a young writer, fresh from England, came to adopt the extravagant life at Calcutta: "As soon as he /the writer7 lands, a banyan, worth perhaps 100,0001 , desires he may have the honour of serving the young gentleman, at $4 \mathrm{~s} .6 \mathrm{~d}$ per month. The Company has provided chambers for him, but they are not good enough; the banyan finds better. The young man takes a walk about the town, he observes that other writers arrived only a year before him, live in splendid apartments and have houses of their own, ride upon fine prancing Arabian horses, and in Palanqueens and Chaises; that they keep seraglios, make entertainments, and treat with champaigne and claret. When he returns, he telis the banyan what he has observed. The banyan assures him he may soon arrive at the same good fortune; he furnishes him with money; he is then at his mercy." see P.H.,Vol.17, Col.356. Charles D'Oyly's Tom Raw, the Griffin, a burlesque poem in twelwe contos, with twenty-five plates, sets ou the same situation. The hero, Tom, a cadet, enters the family of an opulent senior official at calcutta, thanks to a. letter of introduction, and by imitating his life of luxury, ends in total dependence on the moneylender.

2. Lindsay, "Anecdotes of an Indian Life" in Lord Lindsay, op.cit., p.159. 
at Dacca in 1776 to pay off his debts and pocket some thousands of rupees besides. ${ }^{1}$ But as the reforming hands of Hastings and Cornwallis fell on the services, such possibilities of eape disappeared. The sircar tolk great care to secure bonds for whatever he advanced and to add interest regularly. Soon his master found his debt doubled and discovered himself almost beyond the pale of redemption. ${ }^{2}$ Not till they reached the most senior posts could they hope to pay their debts, while numbers, less fortunate, ended their careers in the Calcutta jail. 3 Mackrabie doubtless voiced a common sentiment when he wrote of the sircars or banyans:

"I do most cordially esteem them the Greatest Rogues upon Earth, - that they (the Banyans of Europeans) have been and are, the grand cause of all the Luxury, Extravagance and Extortion of the present time, and will be ultimately that, - of the Ruin of their Country."

The military cadets were perhaps more fortunate in that they foubd borrowing more difficult. But with their small pay they lived a life which initially was as wretched

1. Lindsay, "Anecdotes...." in Lord Lindsay, op.cit., pp. $164-5$.

2. Mrs Fay, op.cit.,p.182; Valentia, op.cit.,vol.1, p.211.

3. Calcutta Gazette, 24 June 1784. Seton-Karr, op.cit., vol.1, pp.20-1.

4. Mss.Eur.E.25, p.89. 
as it could be. Philip Francis commented:

"In my opinion, three-fourths at least of ... the Cadets now sent out are doomed to uncertain Misery; if not to Destruction. For several years they can not even exist without being a heavy Burthen to their Friends in England." 1

The ballad, Ninety-Five, gives a true picture of the unhappy condition of the subaltern in Bengal who attempted to live within his income. ${ }^{2}$ Many, however, did contrive to borrow. Hilliamson, from personal experience, states that subalterns in cantonments often had to borrow from the shroffs or moneylenders "to defray their immediate table expenses". Before he reached the rank of captain, he had been "repeatedly kept from starving by the accommodation afforded by shroffs". Though Williamson comments that their civility and forbearance form a most striking contrast with "the punctual, and greedy, claims of both the Christian and

1. Francis to D'Oyly, $13 \mathrm{July} 1776$. Mss.Eur.E.13, Francis Mss.K.47, p.553.

2. See Appendix II. The state of affairs at Madras and at Bombay was similar to that in Bengal. Of the five rupees Munro used to receive as a cadet in 1780 at Madras, he paid two to a "Dubash", one to the servants of the mess, spent one for hairdressing and washing and was left with one rupee to feed and clothe himself for the entire month. In 1765-6 Forbes said that with his income of $\$ 65$ per annum at Bombay, he could not afford the luxuries of a supper and a candle and went to bed sorely against his will soon after sunset. See J.W.Kaye, "The English in India", Calcutta Review, op.cit., pp.17-18. 
Jewish Shylocks of Britain", I there is little doubt, as Amiya Barat has shown, that the burden of debts was oppressive.

Travellers wrote with husiasm about Calcutta, the City of Palaces, and historians have taken much notice of those who lived as nabobs in Bengal or ended as nabobs in England. Many a poor fellow, however, had to pay a heavy price for the extravagance of life in Calcutta, ${ }^{2}$ and had to eke out a miserable existence in Bengal with little prospect of any comfortable retirement to England.

1. Williamson, op.cit., vol.1, p.343.

2. Hastings himself had later to pay heavily for his extravagant way of living at Calcutta. See Dr. P. Marshall's articles "The Personal Fortune of Warren Hastings", in The Economic History Review, Second Series, Vol.17, No.2., and in the Bulletin of the School of Oriental and African Studies, Vol.28, Part 3. 


\section{LHAPTER VI}

SOCIAL LIFE

In their houses, country bungalows, gardens and array of servants, the English community in Bengal created a setting for their lives which combined elements from both Europe and India. The social life they led in these surroundings was similarly an amalgam of Indian and European ways, Since their community was not a settled one, but was constantly reinforced, in growing numbers, by fresh arrivals from Europe, the basic pattern was that of English society of the landed gentry with their country seats and town houses, of the great merchants of the City of Iondon, and more distantly of the Court of St. James. In detail, however, the pattern was modified by the climate of Bengal, and by customs picked up from contact with the native gentry, Hindu and Muslim, in Bengal.

One of the features of English social life was the rhythm of the year - the flow to London while Parliament was in session and the winter 'season' filled town houses, the ebb to the country or to watering places in the summer and early autumn. ${ }^{I}$ In Bengal, until the development of Simla as a summer capital for the supreme Government ${ }^{2}$ there was not so marked a tide in the affairs of government, though the despatch of the investment from the up-country factories and aurangs, the assembling of cargoes and the

1. Supra, Ch. V.

2. The Imperial Gazetteer of India, Vol.22, p.383. 
preparation of despatches and accounts for the shipping which sailed in a scheduled time for England, did provide a period of exceptional activity. ${ }^{1}$ However the more extreme climate of Bengal imposed a natural rhythm upon social as well as business activity for it was to the cold weather that everyone looked for a period of recreation

Bengal in winter resembles England in spring. "The Air during the Months of December and January appears to us to be as sharp as that in England during the Month of Ilarch", 2 declared Rennell, while William Carey dwelt with pleasure on the winter of 1794-96:

"I was oblized this season to wear my Great Coat the whole day; and yet shivered in the cold."3

This was the eeason for social gatherings, when Calcutta, in summer "as dull as Batb out of season", 4 became alive again with the return of the wealthier British inhabitants from their garden house retreats. 5 Everyone in Bengal,

1. John Benn to bis sister, Hary, I December 1780. Mss. Eur. E 3, p.12. Also see Ch. V.

2. Rennell to Burrington, 31 August 1765. H.M. Vol. $765, p .149$.

3. Carey to Arnold, 13 Harch 1795. Carey's Various Corres pondence, 1795-1831. Box No. IN/13, Letter No. 5. No pagination.

4. Miss Fowke to Miss Baber, 23 April 1778. Mss. Eur. D.10, p.52.

5. Supra, Ch. V. 
official and non-official, looked forward to the cold weather, and the reunion of families and friends.

"Nearly our whole family were ..... collected together at Calcutta during the cold weather", writes E.J.Holland from Madras, "and I frequently lament that I could not be among you to partake of the friendly society you formed." 1 So great was the attraction of the Calcutta season that two ladies thought it worth while to cancel their passage on the Phoenix so as to spend the cold weather (of 1788-9) in Bengal with their friends. 2

Calcutta formed the natural centre for the social life of the British community in Bengal. It was the seat of government to which a man might return to renew useful friendship with kinsmen, school fellows, or in later years classmates from the College of Fort William or Haileybury, and to press claims for promotion or a lucrative posting or contract. Here one would come to stock up with a new sporting gun, porter and madeira, or the latest books. Hexo the husbend and wife wo come to bargain some-fashionable dresses-fox-themselves, to obtain-some European food for their-kitohen and some-European furniture for their bedroom. Here too the batchelor might hope to find a wife, and the father or brother to market daughter or sister newly

1. Holland to ? Miss Fowke, 29 August 1783. Mss. Eur. E3, p.162.

2. Calcutta Gazette, 25 December 1788. Seton-Karr, op. cit., Vol. I, p.279. 
arrived from home. And here were to be found the convivial occasions which broke the monotony and dullness of upcountry Iife in stations where European company was limited and grown over-familiar. Regular home leave was as yet unheard of and bill stations bad still to be opened so that a visit to Calcutta was all the more attractive. The commercial Residents and their assistants would seize the slack season after the despatch of the investment to come into Calcutta, officials from neighbouring districts came in by palanquin or on horseback for the week-end, military officers arrived to spend their leave, 1 for as Spear points out they were not yet segregated in barracks and had long periods of leave. ${ }^{2}$

Many presumably stayed with friends and there are numerous descriptions of the dinner parties given in Calcutta. Mackrabie notes one such occasion in November 1774, writing with a rather superior air:

"Entre Nous. The Evening was stupid enough, and the supper detestable, great joints of roasted goat with endless dishes of cold fish. With respect to conversation, we have had three or four songs screeched to unknown Tunes, the Ladies regaled with Cherry Brandy, and we pelted each other with Bread Pills - a la mode de Bengal."3

The flicking of bread about the table, which Hickey first

1. The journal of Colonel Champion, preserved in the Home Miscellaneous Series (Vol.198) in the India Office Library clearly shows how a military officer could seize his period of leave to spend it in enjoying the social life at Calcutta.

2. Spear, op.cit., p.30

3. Mss Eur. EI5, pp.127-8. 
noted in 1778, was happily indulged in by both men and women. Daniel Barwell was famous for his ability to snuff a candle several times in succession at a distance of three or four yeards with these pills. I Such behaviour might seem to savour of rustic horseplay, but it was in fact copied from the most aristocratic dinner parties, ${ }^{2}$ along with the overeating and overdrinking which Mackrabie describes.

Quite distinctive of India, however, were the parties arranged upon the arrival of ladies from England at Calcutta. 3 This was a great day of rejoicing in the social life of the settlement, for officials and free merchants alike. The leading ladies of the settlement arranged parties for the newly arrived - who sat up in the drawing room for two, three or four nights in succession while the whole town thronged to see them. This was known as "sitting up", and was used as a means of introducing the new comers to the settlement. The spinsters among them frequently obtained a number of offers from the wealthier members of the community, and many matches were indeed concluded even before the third night's sitting.

1. Hickey, op.cit., Yol.2, p.137.

2. Dorothy Marshall, Manners, Heals and Domestic pastimes" in Turberville, op.cit., Vol.1, p.35l. Mackrabie's French - à la mode de Bengal - however suggests that he thought of it as a purely Bengal custom. 3. Hickey, op.cit., Vol.3, pp.159-60. 
The custom was a local development, and was very popular in the early days when the number of European inhabitants was still suall and their houses still closely grouped together. 1

Besides the private house parties, there were a variety of public occasions for social gatherings. Early in December there was the official celebration of the King's birtbday ${ }^{2}$ and then followed Christmas ${ }^{3}$ and New Year festivities. 4 Each was celebrated with public suppers, as well as private gatherings, and the Governor-General gave official parties to the settlement though not, however, on the occasion of Christmas after $1786 .^{5}$ There were likewise public celebrations on such occasions as the consecration of St. John's Church at Calcutta, ${ }^{6}$ upon news of the

1. Williamson, op.cit., Vol.2, pp.113-4.

2. Calcutta Gazette, 9 December 1784. Seton-Karr, op.cit. Vol.1, p.30. The King's birthday actually fell on June but was observed in December at Calcutta.

3. Journal of Mackrabie, 25 December 1775. Mss. Eur.E.25, p.93.

4. Journal of Mackrabie, 1 January 1776. Ibid, p.94.

5. The Calcutta Honthly Register, November 1790, Vol.I, No. $1, \mathrm{p} .40$. Also see below.

6. Calcutta Gazette, 28 June 1787. Seton-Karr, op.cit., p.203. 
King's recovery from illness, ${ }^{1}$ for the British victory over Mysore ${ }^{2}$ and for Warren Hastings's acquittal at his impeachment. ${ }^{3}$ The pattern of court and public life in England thus found its echo in Bengal. Another custom which may have been borrowed from aristocratic life at home, was the giving of public breakfast parties to the settlement, once or twice a week, by the councillors, judges and other senior servants of the Company. ${ }^{4}$ Public breakfast parties were so frequent in the 1740 's at Ranelagh, at Ruckholt near Stratford, at Marylebone Gardens and Cox's, at the Green Man in Dulwich as to draw comment from the Gentleman's Hagazine. ${ }^{5}$ However the breakfast parties in Calcutta may well have derived ratber from the common table of the Company's factories than from English life. The custom was certainly fully entrenched in Calcutta in the early years of our period, and though Francis and his brother-in-law expressed themselves as disgusted by the noise of the crowds at their public breakfasts,

1. Calcutta Gazette, $30 \mathrm{July}$ 1789. Ibid., Vol.2, pp.220-1.

2. Calcutta Gazette, 31 January 1793. Ibid., pp.360-1.

3. Calcutta Gazette, 15 October 1795. Ibid., p.428.

4. Wiliiamson, op.cit., Vol. 2, p.127.

5. Dorotby Marshall, Manners, Meals and Domestic pastimes" in Turberville, op.cit., p.344. 
they were too popular to be abandoned. Francis was certainly still providing public breakfasts once a week until after 13 February 1776, when Mackrabie noted the practice in his journal. 1

If public breakfasts started the Calcutta day, suppers and balls were the common conclusion of the public celebrations of the season. Once again the model to be Hollowed was that of London or of Batb, but the shortage of females ${ }^{2}$ necessarily caused at least one difference in procedure. The normal custom in England was for the same couple to dance the entire evening together, and only in the more friendly and informal occasions would partners be chanced every two dances or so. ${ }^{3}$ At Calcutta, however, the ladies had to dance as many dances as they could in one night, never dancing two country dances with any one centleman, so as to avoid giving offence to the others, eagerly awaiting their turn on the floor. ${ }^{4}$ The wealth of partners may have been gratifying, but for the ladies a ball was a strenuous occasion.

I. Mss. Eur. E 15, p.102.

2. Supra, Ch. IV.

3. Dorothy Marshall, "Manners, Meals and Domestic Pastimes" in Turberville, op.cit., pp.356-7.

4. Golaborne, op.cit., Vol. 2, p.105. 
"Imagine to yourself", writes Asiaticus, "the Iovely object of your aftections ready to expire with heat, every limb trembling and every feature distorted with fatigue, and her partner with a muslin handkerchief in each hand employed in the delightful office of wiping down her face, while the big drops stand impearled upon her toreheàd."I

Supper at nine to eleven p.m. must bave been a welcome break for the ladies before dancing was resumed till the early hours. For the men it was of course the time to start serious drinking till they dispersed next morning. 2 The shortage of women may have undermined etiquette in one respect, but in all others English society in Calcutta imitated that at home. The Governor or Governor-General was expected to maintain a considerable degree of state and ceremony and to entertain lavishly. This was not only in keeping with the Indian tradition of associating sovereignty with splendour, but was also demanded by the British community who wanted to see him reproduce the etiquette and dicnity of the Court at home. ${ }^{3}$ The same regard for social order and for the dues of rank was therefore expected at banquets and at balls. Balls were opened by a minuet, to be followed by country dancing, and it was the

1. Asiaticus (Stanhope), op.cit., p.144.

2. Calcutta Gazette, 3 January 1788. Seton-Karr, op.cit., Vol. 2, p.244.

3. Lord Curzon of Kedleston, British Government in India, Vol. 1, p.202. 
custom for the ladies to be led out for the minuet in strict accordance with the rank of their husbands. Those whose husbands were not in the Civil Service, the King's or the Company's regiments, and those who were unmarried were led on to the floor in the order in which they had come into the room. 1 The dissatisfaction felt by Company's officers at being placed on a lower footing than officers of the same rank in the King's service, was matched in Calcutta society by the disgruntlement of the non-official at the precedence granted to those in the Company's service. There were frequent protests by the non-officials, one of whom bitterly complained that if rank was to enjoy such precedence in social gatherings, the town would soon be strictly divided into parties of those in and those out of the Company's service. 2

Besides the prviate parties, and the public social occasions, there were various activities open to the residents of or visitors to Calcutta. Thus for one hundred rupees one coild become a member of the subscription assemblies, held once a week or once a fortnight from November

1. See for example Calcutta Gazette, 3 January 1788. Seton-Karr, op.cit., pp. 243-4.

2. The India Gazette, Calcutta, 31 October 1785, 


\section{4}

until February. At these the managers provided their hundred or so subscribers with a supper, ball and concert. ${ }^{1}$ From 1774 Calcutta was also able to provide a playbouse after being without one for nearly twenty years. The first playbouse, built in 1745 at Lallbazar, had been used as an outpost in the defence of the town against Siraj-uddaula ${ }^{2}$ and seemingly disappeared in the course of the siege. In 1775 , however, another theatre was built by subscription at the corner of Clive street and Lyon's Range. ${ }^{4}$ The scenery for this Calcutta Theatre was originally furnished from Ingland, under the supervision of David Garrick, ${ }^{5}$ the famous actor at the Theatre Royal in Drury Lane. ${ }^{6}$ The auditorium

1. Calcutta Gazette, 18 October 1787. Seton-Karr, op.cit., Vol. 1, p.225.

2. B.V.Roy, Old Calcutta Cameos, p.125.

3. The Directors, unaware of its destruction, wrote out in 1758 enquiring whether it could be converted into a church or public place of worship. Despatches to Bengal, 3 Iarch 1758, Para. 58 in Long, op.cit., Sec. $296, p .125$. It is therefore incorrect to suggest as Dr. Spear has done that the first theatre built at Calcutta was opened in Hastings ' time (p.34).

4. Roy, op.cit., p.127; Willianson, op.cit., Vol.2, p.201

5. Williamson, op.cit., p.204.

6. W.J.Lawrence, "The Drama and the Theatre" in Johnson's England (edited by A.Turberville), Vol.2, p.1T3. 
consisted of pit and boxes, with seats at eight rupees and one gold mohur respectively. ${ }^{1}$ From 1775 therefore those coming to Calcutta during the 'season' could see dramas such as Hamlet, The Fair Penitent - this as a charity show in aid of the Military Orphanage ${ }^{3}$ - Macbeth, 4 High Life below Stairs, ${ }^{5}$ The Critic, ${ }^{6}$ and High Life above Stairs, ${ }^{7}$ all items from the current repertoire in London, 8 performed by gentlemen players. On other occasions, they could join in Masquerades at the lheatre which were modellec on those at the King's Theatre in London. 9

"The Hasquerade which you may remember we were to have soon after you left us", writes Margaret Fowke to Miss Caroline Clavering, "was as splendid as it was expected. The Theatre was filled up for the occasion with great taste and elegance ..... Mirs. Hajor Iorgan was a

1. Williamson, op.cit., p.202 2. Calcutta Gazette, 11 November 1784 . Seton-Karr, op.

3. Calcutta Gazette, 16 February 1786. Ibid., p.145.

4. Calcutta Gazette, 7 December 1786. Ibid., p.163.

5. Calcutta Gazette, 30 March 1786. Ibid., p.169.

6. Calcutta Gazette, 3 December 1786. Ibid., p.163.

7. Calcutta Gazelte, 11 February 1790 . Ibid., Vol.2.,p. so7

8. W.J.Iawrence, "The Drama and the Theatre" in Turberville, op.cit., p.I60 et seq.

9. Talbot Hughes, "Costume" in Johnson's England (edited by A.Turberville), Vol.2, p.402. 
Minerva - she is become a fine Lady ..... Miss Stark in the character of Secrecy, not improperly chosen for she seldom speaks ..... - the Iadies and their Partners were dressed for the dance like shepherds shepherdesses all in the same colours - The settlement was so well pleased with this Masquerade that soon after there was another by Subscription."I

If the plays were all-male performances, the balance was redressed by the masquerades where the ladies took the lead. The ladies were apparently ready to employ their tongues as well as their graces:

"A Ia derniere masquerade", writes C. von Danckelmann to Margaret Fowke, then probably at Benares with her brother, "Hadame Bristow, Miss [sic] Mears et Mrs. [sic] Collins avoit usé mauvaise pleasanterie qui a produit les pieces que je vous envoye."2

Since gambling, like gossip, was one of the passions of Bengal society, there were clubs such as Selby ' ${ }^{3}$ where the officer or official coming down to Calcutta could game away his salary at Tredille, or Whist or five card 100.4 With five gold mohurs spoken of as

1. Miss Fowke to Miss Clavering, no date. Mas. Eur. D.10, pp.25-6.

2. Danckelmann to Fowke, no date. Mss Eur. E 9, Fowke liss K30, p.237.

3. Kaye, op.cit., pp.100-1.

4. Hrs. Fay, op.cit., p.189. Quadrille which was very popular in London (see Dorothy Marshall, op.cit., p.358) was apparently not much played in Calcutta. See Journal of Mackrabie, 1 September 1775. Mss Eur. E 15, p.95. 
"a very moderate sum a corner"l at whist, the young writer or cadet anxious to cut a figure was presumably able quickly to run himself into debt. There was also much Eambling in private parties. "In the Society in Bengal" writes Joseph Fawke to his daughter, "I defy man or woman to entertain a company without cards." 2 There were wild rumours in Iondon about the fortunes made and unmade in Calcutta at this period. Iady Ann Monson's ${ }^{3}$ and Richard Barwell's ${ }^{4}$ card parties were particularly notorious, and the author of The Intrigues of a Nabob put Barwell's losses to Philip Francis at $£ 40,000$, and asserted that Francis had won thirty lakhs at whist and lost ten thousand pounds at backgamon. 5 There is no evidence to corroborate the exactness of these figures, which may be exaggerated. There seems little doubt however that Francis did win a fortune in India for be himself says as much in his private letters to George Chandler and Joseph Fowke In 1776 he told Godfrey that he had won above twenty thousand pounds

1. Goldborne, op.cit., vol. 1, pp.72-3.

2. Fowke to his daughter, Hargaret, 27 May 1784 Mss. Eur. E.5, Fowke Mss. K26, p.84.

3. Mss. Eur. E.15, p.95.

4. Ibid., p.119.

5. Busteed, op.cit., pp.149-151. 
at whist and had then lost eight thousand, ${ }^{1}$ and in 1777 he wrote to Charles D'Oyly:

"A private Letter from London telis me it is believed that. Barwell had lost sixty Iacks of Rupees. I never heard here that it Exceeded three; of which Leslie \& Lemaistre won a part: - but if I had won a Million, to whom am I accountable for my Conduct?"2

Another famous gambler, who like Francis upheld the Iondon tradition of men like Charles James Fox ${ }^{3}$ in Bengal, was Joseph Fowke. In 1784, so Holland reported, he lost "a Lack forty thousand rupees" after he had won twenty thousand pounds at a sitting. ${ }^{4}$ While he was in England he gamed away his original Indian fortune, and after his return to Bengal lost another five to six thousand pounds at cards, as Francis Fowke complains, whilst he had "an infant family dependent upon him." 5

The outdoor recreations of the Europeans in Calcutta, like the indoor, were mainly brought from home.

1. Francis to Godfrey, 16 September 1776. Mss. Eur. E.13, pp. 745-6.

2. Francis to D'Oyly, 30 June 177. Mss. Eur. E.15, pp. 749-50.

3. I. Steven Watson, the opeit George III, p. 338 .

4. Holland to Fowke, 7 December 1784. Iss. Eur. D.11, Fowke Mss K.25, p.137.

5. Francis Fowke to his father, Joseph. 27 October 1789. Mss. Eur. E. 8, Fowke IIss. K.29, p.232. 
Foremost among them, perhaps, was the evening carriage drive. There were probably tew carriages in Calcutta at the beginning of our period, and ladies ${ }^{l}$ and senior nembers of the service ${ }^{2}$ paid their visits, as did the doctor, ${ }^{3}$ by palanquin. It was a privilege of the Governor to use a carriage, 4 though until Calcutta was opened out, its streets paved, and the Esplanade and the Maidan by the new fort laid out, his privilege must have been of limited use, except as a symbol of status. In 1770 Stavorinus still does not include the evening drive in his list of the activities of a typical lady of Calcutta. 5 Ten years later, however, when the new European quarters round Chowringhee had been opened up, and carriages had begun to be imported in numbers from Ingland, the habit had become established. The carriage was a faster and cooler vehicle than the palanquin, and much better suited to social display. The palanquin continued to be used

1. Carey, op.cit., Vol 1, p.112

2. Bengal Consultations, 27 November 1758. Long, op.cit., Sec. 361, p.150.

3. Carey, op.cit.

4. Kaye, "The English in India" in Calcutta Review, op.cit pp. 26-7.

5. Stavorinus, op.cit., Vol. 1, pp.523-4. 
by the poorer classes of Europeans, the clerks and cadets, I and upcountry where well surfaced roads scarcely existed, the palanquin or dooley remained a necessary means of transport. But those who could afford them, as well as those like writers who could not but who borrowed nevertheless from their sircars, ${ }^{2}$ began to keep carriages. In 1777 Hickey describes the evening carriage parade as already fashionable in Calcutta, and in 1780 a correspondent in the India Gazette thought it necessary to suggest rules for those gentlemen who drove their carriages themselves. 4 In the last decade of the eighteenth century driving a carriage had become so popular that some agencies sprang up at Calcutta to let them to those who could not afford to keep them. ${ }^{5}$ By 1805 the use of carriage had spread even into the mofussil. 6

1. J.W.Kaye, "The English in India" in Calcutta Review, Op. cit., pp.27-8.

2. Iirs. Pay, op.cit., p.182.

3. Hickey, op.cit., Vol. 3, p.153.

4. The India Gazette, Calcutta, 9 Decemier 1780 , No.4.

5. Calcutta Gazette, 20 October 1791. Seton-Karr, op.cit. vol. 2, p.532.

6. John Pester, $\operatorname{Var}$ and Sport in India, 1802-6 (edited by J.A.Devenish), p.445. The arrival of the carriage up country also indicates the growth of European cantonments and civil lines, and a new attention to the road system. The great Mughal highways had decayed in the early eighteenth century, but had been gradually brought back into use by the end of our period. 
With the ladies the keeping up of a carriage was essentially a question of prestige, an item of conspicuous consumption.

"It being necessary", writes Hickey, "to keep a carriage for lifrs. Hickey, I purchased a neat London-built chariot, for which I paid three thousand sicca rupees, a phaeton for my own use at eighteen hundred, and three excellent draught horses which cost me seventeen hundred and fifty, then considered a very reasonable price."l

Irs. Hastings was less fortunate; for when an advertisement for "a very elegant chariot" just imported from England 2 caught her eye in 1780, Warren Hastings upon examination pronounced it "ill shaped, old and vamped" and refused to buy. There was much competition for possession of the most richly decorated carriag in Calcutta, and Sophia Goldborne writes in 1782 with much satisfaction about the effect of hers:

"Not a phaeton on the turf was more noticed than mine, my horses are Armenian, well-trained and bilted my reins elegant - my own dress becoming - the dress of my sepoys magnificent - my attendant beau the envy of the men and the admiration of the women."4

Trevelyan's comment on Stubb's Lady and Gentleman in a Carriage, that "to drive a lady in a phaeton was a fashion-

1. Hickey, op.cit., p.171.

2. Benfal Gazette, Calcutta, 22 July to 29 July 1789. Do. xxvii.

3. Hastings to his wife, Marian, $26 \mathrm{July}$ 1780. Grier op.cit., p.57.

4. Goldborne, op.cit., vol. 2, p.100. 
able diversion in the last part of the century"l was as applicable to Bengal as it was to England. And if the Calcutta Gazette might be believed, at least one newly arrived belle was won by the attraction of riding in a splendidly ornamented carriage on the course. 2

This was the race course near Esplanade, at tirst the usual setting for the evening drive, which took place at a out five o'clock ${ }^{3}$ when the dinner hour was at noon and at about seven olclock when the dinner hour was in the late evening. 5 As in England, ${ }^{6}$ the grooms, the Indian syces who looked after the horses, ran alongside the carriage $^{7}$, an aristocratic fashion vainly condemned by Mrs.

1. See colour plate no. 4 in G.M.Trevelyan, op.cit., facing page 106.

2. Calcutta Gazette, 15 Iarch 1787. Seton-Karr, op.cit., Vol. I, p.199.

3. Goldborne, op.cit., Vol..2, p.94.

4. Hadley, op.cit., p.27.

5. Iord Valentia stated that when the dinner hour shifted to seven o'clock it prevented an evening drive being taken (see pp.195-6). But since Valentia himself states that the hour for dinner extended from seven to eight, it seems likely that the necessary minor adjustment in time was made.

6. E.N.Hilliams, op.cit., p.100.

7. A Young Civilian in Bengal, 1805. Journal of the Calcutta Historical Society, op.cit., p.l24. 
Sherwood as unchristian like behavior. ${ }^{1}$ As the population of Calcutta increased, the concourse of carriages spread to the principal roads, ${ }^{2}$ a dusty contrast to the smooth green turf of the course. A lively, fanciful description of the scene as it had grown to be by 1805 , is given by Henry Roberdau as follows:-

"About a quarter of an hour after sun-set the carriages gradually came out till at last all the city may be said to be assembled; high and low, rich and poor, great and small, all mix promiscuously in this varied scene. There are vehicles of all kinds, Coaches, Chariots, Iandaus, Sociables, Phaetons, Curricles, Buggies \&c. Some of the Equipages are truly splendid. Here you may see some fond but awkward equestrian risking his Neck to keep up with the Landau of his beloved; there aome lone Priscilla (past her teens) rolling in vain her sparkling orb, to allure some wealthy Nabob. Here Youth and Beauty is doomed to drag the chain of three score not lighter to her by being gilt. Antiquated three score sits by bis blooming Bride like an Egyptian Mummy linked to the Venus of Apelles [sic] ..... Who comes here in such a dusty, fusty, musty, rusty, disgraceful carriage? Ob that is Mammon, poor Han, he has not yet quite amassed the crores of Rupees and you know with two millions sterling a Ilan can do but little! This youne Gentleman knows how to make use of the gifts of fortune, I see he has four Horses in his Equipage and everything in equal style. Yes, that is the Youthful Clodio, a writer, and at present receives three hundred Rupees a month!?" 3

Another offieer, visiting Bengal in the early nineteenth century set the seal of approval upon the

I. Irs. Sherwood, op.cit., p.264.

2. A Young Civilian in Bengal 1805. Journal of the Calcutta Historical Society, op.cit., p.123.

3. Ibid., pp.123-4. 
spectacle by declaring that it could "vie with that of Hyde Park."I Jyondon had been revealed in Bengal. The alternative to the evening drive was a boating expedition on the Hooghly, to Garden Reach, Chandernagore, Chinsurah or Suksagar. ${ }^{2}$ Many who disliked taking the dust from the roads turned to the river for its cooling breezes - though even there they might be greeted by unsavoury smells and the sight of animal or even human carcasses on the banks. The more opulent, both official and non-official, kept budgerows and pinnaces, many oared and magnificent ${ }^{3}$ with ornamented prows of bird, or fish, or female figure in floating draperies. The pinnace had a windowed cabin at the stern, while the budgerow was open, with a narrow beak-shaped stern. ${ }^{4}$ Hickey's was the private barge which perhaps drew most attention, for it was forty-eight feet long and had a crew of fourteen. 5 Hastings had his pleasure boat, too, the Feelchehra,

1. An Officer, op.cit., pp.93-4.

2. Holden Furber's, John Company at Work has revealed upon what friendly terms individual English, French and Dutchman lived in the eighteenth century. Also see Price, op.cit., pp.5l-2 and below.

3. Busteed, op.cit., pp.123-4.

4. Mirs. Sherwood, op.cit., p.266.

5. Hackrabie quoted in Kincaid, op.cit., p.90. 
wrecked off Nayaserai, ${ }^{I}$ and Wellesley kept a magnificent state barge, richly ornamented with green and gold with a gilt spread eagle at its bead and a spxinging tiger at its stern. ${ }^{2}$ Crews might be dressed in white linen trousers and jackets, with bright red or green turbans and cummerbunds of the same colour at their waist. ${ }^{3}$ With Kittesan or Umbrella boys in similar uniform holding sunshades over the heads of the company, and bands playing on board, the oars beating time to the notes of the clarionet, the boats formed a most picturesque sight. As Sophia Goldborne said, even the handsomest nobleman's barge on the Thames would have cut a poor figure before the budgerows and barges of Calcutta. 4

Horse racing, which was a popular diversion among all classes of people in England, a country pastime just emerging at Newmarket as a national sport, ${ }^{5}$ came into fashion in Calcutta in the $1780^{\prime} \mathrm{s}$. Stocqueler in his

1. Grier, op.cit., p.55.

2. Valentia, ap.cit., p.36.

3. Nackrabie quoted in Kincaid, op.cit.

4. Goldborne, op.cit., Col. 1, pp.15-6.

5. E.D.Cuming, "Sports and Games" in Johnson's England (edited by A. Turberville), Vol. I, pp.362-4. 
Handbook of British India asserts that "the first record of the existence of racing in Calcutta may be dated from the origin of the Bengal Jockey Club in 1808."I But Hicky's Bengal Gazette for 23 November 1781 reports,

"On Thursday last before a very brilliant Assembly of the most perfect and Accomplished beauties in the Presidency Attended by a numerous Cavalcade of Gentlemen of the highest iank and abilities in Calcutta who to a man were dying swains and danglers at the shrine of Beauty Was Run for 4,000 sicca Rupees by Mr. Prinsep's Gray Horse, New Pice against IHr. Touchet's Bay Horse, New Rum - New Pice beat New Rum quite Hollow."2

And in the following winter season Sophia Goldborne refers to the race course at calcutta ${ }^{3}$ and describes a race she witnessed with her father where "the spectators were numerous - many oi which were Hoors."4 Again in the 1789-90 season Grandpré speaks about the Calcutta races and the breeding of horses in Bengal. ${ }^{5}$ By 1793 races were being held regularly on the Calcutta course on ilednesdays, Thursays and Fridays in the morning. They were followed by a public breakfast, with nusic, and by a ball and supper

1. J.H.Stocqueler, The Handbook of British India, p.179.

2. Bengal Gazette, Calcutta, 27 October to 3 November.

3. Goldborne, op.cit., Vol. 1, p.148.

4. Ibid., Vol. 2, pp.101-3.

5. Grandpré, op.cit., Vol. 2, p.16. 
on Iriday evening, ${ }^{1}$ - a custom unhappily since discontinued. Cricket, yet another English country sport which had been taken up by the nobility, ${ }^{2}$ was also to be found in Calcutta, and once acain earlier than has hitherto been realised. Cotton in his Calcutta Old and New gives a. cricket match played on the eighteenth and nineteenth of January 1804 between the Ettonian civilians and other servant of the Company resident in Calcutta, as the first notice he could fine, of the game being played in Bengal. 3 In fact the Bengal Gazette records a game as early as 23 December $1780 .^{4}$ Roberdau's account of tennis at Calcutta in $1805,{ }^{5}$ Sopbia Goldborne's account of billiards ${ }^{6}$ and angling ${ }^{7}$ in 1782 and the Calcutta lazette's report of fencing

1. Calcutta Gazette, 12 עecember 1i93. Seton-Karr, op.cit. Vol. 2, pp.374-5. For a modern analogy to the Calcutta races with breakfast and suppers, see Indian Cavalryman by Capt. Freddie Guest, a cavalry Officer at Foona in early twentieth century.

2. Coming, "Sports and Games" in Turberville, op.cit., pp. 371-2, 378-9.

3. Cotton, op.cit., p.151. The Etonian Civilians won by 152 runs.

4. Bengel Gazette, Calcutta, 16 to 23 December 1780, No. IIViij.

5. A Young Civilian in Bengal, 1805. Journal of the CalCutta Historical Society, op.cit., p.119.

6. Goldborne, op.cit., Vol. 1, p.146.

7. Ibid., Vol. 3, pp. 14l-2. 
in $1787^{1}$ are likewise almost certainly capable of being antedated from other writers and newspapers.

Finally, as perhaps the most widely shared outdoor recreation of the Europeans in India, there was hunting and shooting. lihe shooting at all kinds of birds and game, and hunting on foot or on horseback after deer, fox, badger, hare or otter bad long been popular with all classes in England, though not all the sports had been legally pursued. ${ }^{2}$ Since game birds and animals like bog, deer, jackal, duck and snipe, many of them known to England, were available all over the Bengal Presidency and even within the short distance of Calcutta, ${ }^{3}$ enthusiasm for sport was easily satisfied. This was an activity in which civil and military men, up country indigo planters or Calcutta merchant could all share on equal terms, and in wilch the social advantage or disadvantage of one's place of birth counted

1. Calcutta Gazette, 25 January 1787. Seton-Karr, op.cit.,

2. Cuming, "Sports and Games" in Turberville, op.cit., p. 366 et seq.

3. Mss Eur. E23, Francis Mss K66, p.79. The existence of fox is very doubtful in Bengal. The contemporaries mistake the jackal in Bengal for fox in England and speak of fox hunting. 
not at all. 1

In Bengal the butting season commenced in November and was supposed to end in April, ${ }^{2}$ though probably any occasion for sport that offered was always taken. A pack of hounds was maintained by the British inhabitants at Calcutta ${ }^{3}$ and other packs at such Bengal military stations as Berhampur and Dinapur ${ }^{4}$. Richard Barwell kept a hunting lodge at Baraset from which parties often went out ${ }^{5}$ and llackrabie reports the existence in 1774 of a sporting club in Calcutta which went hunting on sundays. 6

1. The ramners and accomplishments of the cadets and writers coming out to India doubtless differed widely in 1768 for example there were writers from Somerset, Westminster, Armagh, the West Riding of Yorkshire, Hereford and Berkshire and cadets from Vaterford, Salisbury, Lancashire, Switzerland, Devon, Yorkshire, East Lothian and Lough - and their backgrounds must have differed greatly. Nevertbeless all must bave been acquainted with country sport. See Chs. II and III

2. Stocqueler, op.cit., pp.181-2

3. Mss. Eur. E.15, p.101.

4. Stocqueler, op.cit.

5. liss. Eur. E.15, p.98

6. Mss. Eur. E.25, p.53. 
In the up-country district where many of the diversions of the Presidency town were lacking, hunting was a favourite recreation of the scattered knots of civilians and of the military officers.

The most popular sport was hog-hunting - so popular indeed that Williamson devotes seven plates and twenty-eight pages to describing its detailed pleasures. 1 But there were also tiger, Leopards, wild buffalo ${ }^{2}$ and even rhinocerous ${ }^{3}$ to be had in abundance in Bengal. In this respect at least the Bengal hunter had opportunities to: show their skill which were denied them in England. With the muzzle-loading flint-and-steel guns then available ${ }^{4}$ such big game were very dangerous, and there are many accounts of fatalities among their hunters. Thus two nembers of a hunting party at Plassey in 1785 narrowly escaped being killed by a tiøer; ${ }^{5}$ Colonel Patrick Duff, better known as "Tiger Duff", a man of prodigious strength, was "squeezed

1. Capt. T. Williamson, Oriental Field Sports, Plates 1-7, $\mathrm{pp} \cdot 1-28$.

2. LonE, op.cit., p.3.

3. Williamson, op.cit., plate 11, pp. 44-7.

4. Trevelyan, op.cit., p.11.

5. Whe India Gazette, Calcutta, 29 August 1785, Vol. 5, 
to death" by a tizer ${ }^{1}$ and in December 1792 Lieutenant Munro lost his life in the sport. ${ }^{2}$ Hunting on foot in the thick cover then common in Bengal was certainly dangerous, but the use of a machan or of elephants, Grandpré declares, so reduced the danger that ladies often joined the party. ${ }^{3}$ Forbes describes a tiger shoot organised in 1784 in which thirty elephants were employed. The guns included a number of high officials and the portrait painter Zoffany. Several ladies were also present and accompanied the guns on the elephants. ${ }^{4}$ sport was certainly good for in 1785 Forbes met a shooting party which in the course of one month had killed "one royal tieer, six wild buffaloes, one hundred and eighty-six hog-deer, twenty-five wild hogs, thirty-five hares, one hundred and fifty brace of partridges and floricans with quails, ducks, snipes and smaller birds in abundance." 5 With the advent of sporting rifles,

1. Ross, op.cit., Vol. 2, p.62.

2. Calcutta Gazette, 3 January 1793. Seton-Karr, op.cit. Vol. 2, p.359; Twining, op.cit., pp. 480-1. Twining discusses the dangers of tiger hunting.

3. Grandpré, op.cit., Vol. 2, pp. 47-8. Plates 14-2l in Wiliiamson, op.cit., pp. 56-85 describe tiger-hunt in details.

4. J. Forbes, Oriental Hemoirs, Vol. 2, p.489.

5. Ibid., Vol. 4, p.99 
mentioned by John Pester at Bareiliy in his diary for $1803,{ }^{1}$ big game hunting became even more and successful. Meanwhile like the cadets at Baraget ${ }^{2}$ many must have continued to chase and shoot anything that offered, even to kites and crows. ${ }^{3}$

Most, if not all of the aspects of European social life in Bengal so far described were carried to India from home and superimposed upon Indian life. The borrowing was from middle and upper class England, not from India. Indeed many European habits, mixed dinners and dances for example, must have seemed most barbarous and offensive to a cultured Indian, whether Ifuslim or Hindu. But side by side with these importations from England, there were also borrowines from Indian life made by the British as a result of their contacts with the native gentry, Hindu and Iilusim in the years after Plassey. This contact begun at Murshedabad after the grant of the Diwani in 1765, was markedly increased after the appointment of supervisors to the districts in 1769 and then of the collectors and assistants after 1772. The appointment of Residents and political

1. Pester, op.cit., p.85.

2. Carey, op.cit., Vol. 1, p.241.

3. Calcutta Gazette, 24 January 1788. Seton-Karr, op.cit. 
officers to all the major courts of India which was virtually complete by Wellesley's day, further extended such contact and acquaintance with Indian society at its highest levels. As will later be seen these extensions of contact did lead to some genuine meeting of minds, to the lore, in a few of Persian literature, to an interest in Indian history and customs, to a knowledge of Hindu and Iuslim law, and necessarily to some understanding of the structure of society and of its administration. Often however the contact resulted in obvious but superficial borrowings, on a par with the adoption of Indian dress and diet made by the earlier merchants of the Company.

One of the borrowings which attracted the attentio of later arrivals was the British "addiction to the nautch", to Indian dancing. This was considered by the native gentry to be a recognised form of entertainment for their European Euests. 2 Gradually it became an amusement in the British community itself, as Sophia Goldborne noted, 3 so that llackrabie could find Europea entertaining their friends with Indian nautches. Thus in his journal for November 1775 Mackrabie records:

1. Spear, op.cit., p.35.

2. Kindersley, op.cit., pp. 230-1.

3. Goldborne, op.cit., Vol. 1, pp. 76-7. 
"Irast night I supped at the House of a Gentleman who has been two months persuading me to see a Girl dance. You have heard and read of the Indian Dancing Girls .... There was one Principal Girl who has a thousand Graceful Airs \& a deal of Expression. I could discover some plan in her operation. Her Gesture well adapted to the Tones of her Voice."I

Another habit, more widely borrowed and longer lasting, which the British community borrowed was that of smoking the hookah, "a most curious machine for smoking tobacco through water, the smoke being conveyed by a tube of amazing length, which is called a snake and is washed with rosewater." 2 The hookah was used by all classes of Indians and as Dr. Spear has shown was early known and accepted by European settlers. 3 But it was after Plassey that the use of the richly ornamented bookah, and the employment of a hookah bardar became a ritual, almost a sign of status. In the second half of the eighteenth century there are numerous references to hookahs in the inventories in the Nayor's Court at Calcutta, and Asialicus writing in 1774 , comments that most men who had resided any length of time in India had become addicted to the hookah. 4 Iacantosh, another visitor to Bengal in the same

1. Mss. Eur. E.15, p.141.

2. Asiaticus (Stanhope), op.cit., pp. 33-4.

3. Spear, op.cit., p.98.

4. Asiaticus (Stanhope), op.cit. 
period, found that for official and non-official smoking their hookahs during breakfast and at dinner bad become part of their way of life. ${ }^{1}$ In 1778 when Hickey at a dinner party at Daniel Barwell's expressed his dislike of the hookab when he tried it, he was told, "You might as well be out of the world as out of the fashion. Here everybody uses a hookah, and it is impossible to get on without it." 2 In the invitation cards sent out by Warren Hastings to their dinner Euests, the latter were asked to bring their hookahs and the hookahbardars who prepared them with them. ${ }^{3}$ The ladies too were expected to smoke the hookah, though it is not clear when this habit began at Calcutta. Sophia Goldborne believed that it started first with the "country born", 4 the Anglo-Indians, in the early eighties of the eighteenth century. (Niany Indian Court miniatures of course show ladies smoking the hookah. ${ }^{5}$ ) Certainly it was the general fashion by the time Grandpré came to Calcutta in 1789 .

"The bighest compliment they can pay a man" he writes, "is to give him preference by smoking his hookah.

1. See Appendix VI

2. Hickey, op.cit., Vol. 2, p.136.

3. Carey, op.cit., Vol. 1, p.71; Benstead, op.cit., p.142

4. Goldborne, op.cit., Vol. 1, p.145

5. See, for examle, plate xiii in Indian Art, edited by Sir Richard Vinsted. 
In this case it is a point of politeness to take off a mouth piece he is using and substitute a fresh one, which he presents to the lady with his hookah, who soon returns it." I

Captain Price adas the very practical comment that not only did the ladies like the mixture of sweet scented Persian tobacco, sweet herbs, coarse sugar, spices and other ineredients used in the hookah, but that they much approved the fact that the smell of the smoke never remained in their clothes or in the furniture of the rooms. 2

The borrowings from Indian society were probably more important in those features relating to outdoor rather than to indoor life, and were certainly greater upcountry and in the districts than in the Presidency town. The Company Official engaged in land revenue work, the army Officer in cantonment or on the march, 3 both with tented camps and a retinue of servants, with horses even elephants and a train of baggage animals, lived a life which had many parallels with that of the linghal ofticial or officer whom he was replacing. The Fmperor Babur's

1. Grandpre, op.cit., Vol. 2, pp.12-3.

2. Capt. J. Price, op.cit., p.78. A very fine miniature of the Delhi School, now in the India Office Library, Iondon, showine a Company civilian and an officer watchine a nautch, with a superb hookab to hand, has been used by Dr. Spear on the cover of his A History of India, Vol. 2, Penguin Books, 1965.

3. I.H.Thornton, Iight and Shade in Bysone India, p.32. 
liemoirs give a picture of bunting, of boating parties, of bouts of hard drinking, ending maybe in a wild drunken ride, and of pleasure taken natural beauty. ${ }^{1}$. The autobiography of the Emperor Jahangir gives a similar picture of great hunting parties, with large bags of mixed game, and equally of the delight taken in fine scenery and fine Eardens. 2 At a humbler level, the personal history of IIirza Nathan, a lifugal Officer serving in Bengal in the time of Jahangir and Shah Jahan, depicts a Iife lived on horseback and under canvas for many months of the year, of hard campaiøning interspersed with spells of relaxation in which drinking played a fuml part. ${ }^{3}$ The English in eichteentb century up country India lived a life not very dissimilar in essentigls, though on a very modest scale. The officer, the district official, even the planters and merchants, drank and rode, ${ }^{4}$ shot and hunted, adopting pig sticking and tiger-hunting from elephant or machan, with the same enthusiasm as their Indian precursors.

1. See d.S.Beveridge's translation of Baburnama, Iondon, 1922.

2. See A. Rowers's translation of the Tuzuk-i-Jahangiri, edited by H.Beveridge, Iondon, 1909-14.

3. See M.I.Borah's translation of Bahäristān-i-Ghaybi in 2. vols, Gauhati, 1936.

4. Polo does not seem to have been adopted by the British in Bengal in our period. 
The chronicle of Birbhum taken down by Sir Villiam Hunter from a cook who could recall the earliest years of the English in that district tells much the same story of an Indianised European life up country. "Of the Collector, the cook records:

"The first English Lord of Beerbhoom was Keating Sahib. Min mother held me up in her arms to look at him when he passed with his Sepoys and elephants." And of the life of Cheap, the commercial resident, he says:

"He had a great house on the top of a hill, with a wall all round, higher than the ramparts round the fort in Calcutta. Vitbin the wall were gardens and orchards bearing many fruits; also many houses and stores . . . He had about sixty house-servents in all, with many horses, and an aviary full of strange birds. Deer used to run about in the pleasure-grounds." I

This raight be a description of an English gentleman in his country seat, but it could equally be the description of a Zamindar or hich linghal official in his palace-fort. It is probable that where the Europeans were few and isolated Indian influences predominated.

The movement of Europeans up country, and the Erowth of nore regular contact with Indian Court life added new aristocratic overtones to their way of life. This could be observed in the life of a man like Colonel Collins, Resident at Jaipur, whose noble suite of tents, which "might have served for the Great Mogul", housed his

1. Hunter, op.cit., pp. 422-3. 
servants and zenana, and who maintained a private artillery brigade, in the late eighteenth century, ${ }^{1}$ or in the life of Ochterlony ${ }^{2}$ or Hetcalfe at Delhi in the early nineteenth century. 3 It can be seen also in the attempt to take over Indian styles of public display, as for example the provision of animal fights for the entertainment of distinEuished visitors. This had become a regular custom among the nawabs and princes, 4 and when Clive on the assumption of the Diwani in 1765 wished to entertain Shuja-ud-daulah, animal fights were arranged as a part of the celebrations at vast cost to the Company. 5 In December of that same year Clive adopted the same Iugbal style when the French and Dutch governors of Chandernagore and Chinsurah paid a good will visit to Calcutta, to congratulate Clive on the acquisition of the Diwani. Colonel Champion, who witnessed Clive attempt to entertain in true Nawabi style, noted in his journal that the whole town assembled to witness the animal fights. Champion, however, records the fights as disapp-

1. Thompson, op.cit., p.32.

2. Heber, op.cit., Vol. I, pp. 626-7.

3. Thompson op.cit., pp. 149-50.

4. Wilizamson, op.cit., plate 24, p.92.

5. Blechynden, op.cit., p.116. 
ointing: a buffalo furiously attacked a tiger and lifted and threw him easily, but "as there was no opposition it afforded but little sport or pheasure", camels were brought in to fight, which bit each other's legs, but afforded "no diversion", finally there was as crowning spectacle a fight between an elephant, which ran amok and a rhinocerous, but, Champion notes, "as the Rhinoceros could not be moved there was no battle." From the Colonel's journal it would seem that much the liveliest part of the entertainment was when the elephant, which had been trained for battle, ran wild, It endeavoured to force the square, killing seven of the people lining it, then ran through a garden wall, and finally lifted the roof off a house before he was brought to his senses by the mahout. 1 Animal fights were not thought particularly good fun - except in the more plebian form of cock-fighting ${ }^{2}$ and bear baiting, particularly indulged in by the cadets at Barasit ${ }^{3}$ - and on the grand scale they were very expen-

1. Journal of Col. Champion, 17 Decerber 1765. H.M., Vol. 198, pp. 293-4.

2. Cock fighting was not only enjoyed by military cadets, of course, witness Zoffany's famous picture of "Colonel Mordaunt's Cock Match" tnizoffany's "Cock Match at Lucknow" edited by H.E.A.Cotton, plate facing page 127.

3. Carey, op.cit., vol. I, pp.241-2. 
sive. The fights put on for the Nawab of Oudh by Clive in 1765 cost Rs. 2,812/- for the feeding and housing of the animals and the pay of their trainers. I Such lavish and exotic expenditure was frowned on by the Court of Directors ${ }^{2}$ and after 1766 there is no further mention of animal fights at Calcutta, though Vellesley was entertained by the Nawab of Oudh with such spectacles. ${ }^{3}$

In the closing years of the eighteenth century the social life of the Europeans, and more especially in Calcutta, can be seen perceptibly to change. The enlargement of their numbers, the development of a more settled and assured life, the change in the political position of the Company relative to other Indian powers encouraged change from within, while the steady flow of newcomers from England brought with it the altered manners of that country. In most fields the tendency of all these changes was in the direction of a greater Anglicisation, a movement towards greater soberness and refinement and at the same time a withdrawal from Indian modes of life.

1. Blechynden, op.cit.

2. Until the end of our period the Court of Directors were advising their servants in Bengal to be frugal in amusements. See Despatches to Bengal, 25 Ifay 1798, paras. 75-6. D.B. Vol. 32, p.407 et seq. 3. D'Oyly, op.cit., plate.20. 
At the beginning of our period Bengal was still a frontier territory, where adventurers looked for quick fortunes, from war, political revolution and from corrupt contracts and abuse of power. There was no certainty that good fortune would last, the control which Clive imposed by force of personality upon MirJafar night be thrown off by a Mirqasim, the lucrative posting awarded by Hastings might be cancelled by Philip Francis, the Court of Directors' care for their proteges might be overruled by an impatient Parliament or undermined by the group conflicts of Sulivan, Clive and Johnstone. As Marshman put it, rather unfairly, "England had subdued Bengal, and Bengal had subdued the morals of its conquerors."I The Select Committee at Calcutta in 1765 expressed the same sentiment, without the imputation asainst Bengal, when it wrote "every spark of sentiment and public spirit was lost.. . In the unbounded lust of unmerited wealtb." 2 And Francis sums up one side of the period equally well with his comment: "Whenever I am worth a clear entire sum of forty thousand pounds, secure in England, Bengal may

1. John Clark Ilarshman - The Life and Times of Carey, Marshman, and Vard, vol. I, p.41.

2. Embree, op.cit., p.29. 
take care of itself."I In such a gold rush atmosphere hard drinking and gambling, a coarseness of manners, an open-handed hospitality were the natural expression of bectic uncertainty. ${ }^{2}$

By the close of our period, however, the Company's dominion in India was firmly established, no longer seriousIy threatened by European rivals or Indian powers. The prospects of "presents", though not of "prize money" had disappeared, the dustack had been abolished, and except in the commercial branch the privilege of private trade likewise, bounds had been set to the prospects of sudden promotion and so to the faction fighting which had marked the sixties and seventies, and the provisions of the India

1. Francis to Godfrey, 16 September 1776. Mss. Eur. E.13, p. 749 .

2. Joseph Fowke's letter to his daughter Margaret, written on 2 October 1786 when she was about to leave Bengl for England ts a reminder that this was an extravagant period there too. He said, "Your Brother's [Francis Fowke's] fortune joined to other reasonable expectations, will, as far as fortune goes, enable bim to move in the circle of the Gentry, and in that circle I think you are most likely to meet with happiness . . Y Your Brother will find nine-tenths of the gentry spend their Evenings at one of the three Great . . . gaming clubs. . - and ninetenths of the Ladies of fashion spend their time much after the same manner in societies of their own where there is much intrigue." See Mss Eur E6B, Fowke IIs K27, p.218. 
Act of 1784 as administered by Cornwallis had reduced the feverish hope of fortune to the more sober anticipation of a competence. Such a change of prospects brought a more stable outlook, an acceptance of service in Bengal as a career rather than as an adventurous interIude. In 1789 Cornwallis could inform the Court of Directors that he had noted a tendency among the Europeans, especially the officers, towards settling in Bengal as colonists instead of returning to their native country. ${ }^{1}$ Such a readiness to contemplate settling in India also indicated that the terrors of the climate and tropical disease were also abating. Calcutta was becoming a city in which Europeans could contemplate a more normal expectation of life. It had been called a second Batavia, or the Golgotha of India because of its unhealthiness. ${ }^{2}$ In Clive's day it was still surrounded by undrained swamps, 3 swarming with mosquitoes and with sunderbund jungle infested with alligators, wild boar and tiger. 4 During the hot

1. Cornwallis to the Court of Directors, 6 Harch 1789. Ross, op.cit., Vol. 1, p.542.

2. Clive's letter to Court, 22 August 1757, para. 2, in Long, op.cit., Sec. 265, pp.112-3.

3. In Thomas Daniell's picture of a part of Chowringhee done in the 1780's such swamps and pools can still be seen. See plate 6 .

4. Long, op.cit., p.10. 
months of April, Hay and June, the Salt Water Iake to the North east of Calcutta dried up - ading its quota of rotting fish and vegetation, ${ }^{1}$ to the smells of an unsanitary city, where putrifying bodies, human as well as animal might be left for days together under a blazing sun. 2 The city's drinking water originally came from the tank in the present Dalhousie Square, a bathing place for both humans and such animals as the pariah dogs which scavenged the streets. During the ruiny season, from July to September, such surface sources of drinking water were contaminated from the Portuguese burial ground in the very centre of the city, ${ }^{3}$ and by the summer accumulation of buman excrement which were carried by the monsoon floods. Of one of the principal tanks of Benares the engineer F. Wilford reported on 26 July 7790 ,

"It is the receptical of all the drains and filth from the adjacent high grounds. To its banks crowds of people resort all day long on particular call and the stench occasioned by it is hardly to be described."4

1. Rennell to Burrington, 22 September 1765, H.Ii. Vol. $765, \mathrm{p} .152$.

2. Grandpré, op.cit., vol. 2, pp. 6-7.

3. Hicky's Bencal Gazette, April 1780 as quoted in Busteed, op.cit., pp. 165-6.

4. Allahabad Central Record Office, Basta 28, Vol. 32, Remarks on the Town of Benares by F. Wilford Surveyor, Quoted in Cohn, op.cit., pp. 182-3. 
Malaria and cholera were rampant in these months, since no one as yet had connected the one with the mosquito and the other with contaminated water. The doctor's medical skill $^{1}$ was limited to the administration of wine, ${ }^{2}$ the letting of blood, ${ }^{3}$ and dosing with purgatives, though quinine was known and used, having been introduced by the Portuguese. 4

For the convalescent who survived the doctor's care - almost none survived the surgeon's - there were as yet no hill-stations, no modern sanatoria. ${ }^{5}$ A trip to

1. Hicky attacked the skill of the doctors in Bengal by publishing a satirical poem on them which starts thus: "Some doctors in India would make Plato smile, If you fracture your skull they pronounce it the bile, And with terrific phiz and a stare wost sagacious, Give a horse-ball of jalap and pills saponaceous." See Bengal Gazette, Calcutta, 17 to 24 February 1781, No. 5, ior the rest of the poem.

2. Supra, Ch. V.

3. Busteed, op.cit., pp. 169-170.

4. Aldo Castellani and Albert J. Chalmers, A lianual of Tropical lledicine, pp. 25-6.

5. It was only after the acquisition of Darjeeling by the Britisb goverment in 1835 that the official and non-official European fanilies in Bengal could have a hill-station cum sanatorium. See "lhe Imperial Gazetteer of India, Vol. 11, pp. 178-9. 
Chittagonj, ${ }^{1}$ a resort to Ladras, ${ }^{2}$ a journey by river ${ }^{3}$ were all that the patient could look to as aids to his recovery. It was on such a voyage to liradras in search of health that liackrabie died. ${ }^{4}$ Home leave was almost out of the question for a Company servant, for on being invalided bomeobe resicned his position, unless entrusted with official despatches, and could only return with the express permission of the Court of Directors, since the period of leave was not counted as service. ${ }^{5}$ The hazards of a passace during the years of war with France ${ }^{6}$ and the heavy cost of a passage - $\$ 500$ or more for a tamily cabin ror the single journey ${ }^{7}$ - added further barriers. As a

1. Francis to D'Oyly, 2'2 January 1776. IIss Tur. E.13,

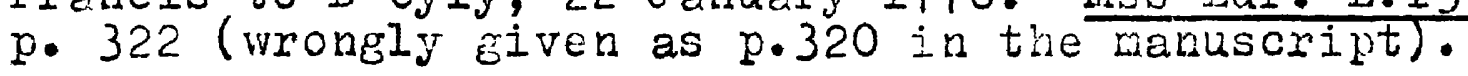

2. Irackrabie to bis friends, 17 January 1776. Iss. Eur. E.25, p.94.

3. IIs Iur. E.15, pp. 110-1.

4. Francis to Viscount Burrington, 9 January 1777. Ibid. p. 464 .

5. Letter to Court, 7 December 1782 and letter from Court, 10 September 1783 paras $13-4$ in 13 . A. Salatore, op.cit., pp. 125, 331. Also see Ch. III.

6. Francis to Godfrey, 2 Iarch 1780. Inss. Eur. E.18, Francis liss I53, Letter *o. 52, no pasination.

7. Iirs. Sherwood, op.cit., p.353. 
result Bengal, a land of exile $e^{l}$ also often became a crave. ${ }^{2}$ In the early years of our period nost Europeans were uncertai whether they would live the season out, and the bottle and board to which they turned for comfrot often ensured that they would not. A note for 12 December 1777 in one of Hr. Justice Hyde's seventy three volume journal expresses the common feeling of insecurity: "If I should die out of Ingland, which most probably be my fate, though I am now, thank God, in a very good health, I desire that these my reports or notebooks may be sent to Ineland." 3 As Philip hason puts it, "the funeral bells toll through Hickey's pases as steady as the hours in a cathedral close."4 By the last decades of the century, however, Calcutta and suci upcountry stations as Benares were throwing off their reputation as the white man's Erave. This was nainly due to the development of new European quarters,

1. With the improvement of comunications, introduction of leave rules and reduction in the cost of passage, Bencial became a land of "temporary exile" in the second and third quarters of the nineteenth century. See F. Lax Huller, India: What can it teach us?, p.39.

2. Cf. "Husbands saw their wives and wives their husbands slowly wasting away before their eyes, and were helpless to save them." See A.I. Davies, Warren Hastings, p. 389 .

3. Selections from the lNote Books of Justice Hyde in the Journal of the Calcutta Historical Society, 1909,

4. Mason, op.cit., p.161. 
laid out more spaciously and with due attention to sanitation, outside the Indian towns proper - Chowringhee at Calcutta, Secrole two miles outside Benares. The jungle outside the former town had been pushed back and some of the more offensive, and malarial marshes had been drained. A more moderate diet and a greater understanding of the demands of the climate also saved life. Residents in Bengal were advised to be temperate in their eating and drinking, and warned against drinking water from the city tanks. There may also have been some improvement in the standard of medical care ${ }^{l}$ - the use of quinine and of innoculation against smallpox were certainly coming in at this time - in 1786 for exarple fifty six children of the Military Orphanage were successfully inoculated by the surgeon Ir. Nasmyth at the request of the managers of the society. Nine children who had not been inoculated caught the disease, and of these three died. ${ }^{2}$ In the same year the Company's hospital which had been transferred to the more healthy site of the present Presidency General Hospital was placed under the efficient management of the military department. ${ }^{3}$ In the last decades of the century there

1. Tennant, op.cit., Vol. 1, pp. 76-7

2. Calcutta Gazette, 4 Iray 1786. Seton-Karr, op.cit., Vol. I, p.149. In 1789 the children of Charity School were incoluated against smallpox. See Hyde, op.cit., pp. 237-8.

3. Hyde, op.cit. 
were to be no such disasters as that of 1757 when in few months after 7 August 1757, 1147 patients were admitted to the European hospital, of whom 180 died from scurvies, putrid fevers, fluxes and the like. ${ }^{1}$ Between 1759 and 1779 the average number of European deaths was 212 a fear; from 1788 to 1800, when the population of Calcutta was vastly larger the annual rate had fallen to $165 .^{2}$ In 1798 Sir John Shore was ab̆le to report to his wife Charlotte that "Of a tontine of more than a hundred subscribers of various a fes and constitutions, formed upon a principle of survivorship, not one member died in the course of three years. I doubt if any climate in the world could exhibit a stronger proof of a salubrious air." 3

A third factor making for a more normal, more regular Iife among the Europeans in Bengal, was the coming of royal troops and officers, of councillors, and of judges and advocates. In the last two decades of the eighteenth century, war with Haidar Ali and the Illarathas, 4 and the campaigns designed to thwart the French in Indonesia and

1. Capt. Edward Ives, A Voyage from England to India in the year $1754, \mathrm{p} .446$.

2. Asiaticus (J. Hawkesworth), Calcutta in Days of Yore, pp. 54-5. The average European death rate per year has been calculated from the tables of mortality in Bengal from 1759-79 and from 1785-1800 as given by Hawkesworth.

3. Shore to his wife, Charlotte, 24 lilay 1789. Teignmouth, op.cit., Col. 1, p.197.

4. Barat, op.cit., p.54. 
in Egypt led to a very considerable flow of royal troops to India. As Dr. Spear points out, "They were not only military, they arrived too mature to be influenced by existing Anglo-Indian manners." 1 His comment can be applie with no less force to the members of the Governor-General's Council and to the judges and lawyers of the Supreme Court, who helped to set the tone for civilian as the royal officer did for military society. Even more important, from 1786 the practice began of appointing men already distinguisbed in English public life to fill the supreme office of Governor-General. When Cornwallis arrived in Bengal be brought with him an established reputation, which Yorktown bad not diminished, ${ }^{2}$ and an assured social position. He was not like Hastings "a native of India", 3 and he did not inherit any Indian tradition but was ready rather to impose Enclish instituions and ideas upon Bengal. 4 The government he created was not therefore a compromise between Indian tradition and English influence, but was purely English in

1. Spear, op.cit., p.3l.

2. Aspinall, op.cit., p.8.

3. J. Parkes and H. Merivale, Memoirs of Philip Francis एol. 2, p.58. Hastings spent at least 35 years in India having come to Bengal as a writer in 1750. For a brief sketch of Hastings's career see Appendix 1 in S.O.Grier, The Great Proconsul, pp.429-31

4. C.H.Philips, India, pp. 62-4. 
character. $^{1}$ He had not like Hastings risen from the humble post of writer to the rank of Governor-General, and he was not forced by inadequate powers to manage men who were old associates in the Company's service, and he was also able therefore to impose English standards upon the Company's service and the British community. Wellesley, coming out with the same advantages as Cornwallis, pushed the change still further, emphasising the break with the commercial past of the Company, and the distance between British and princely India.

The coming of men taken as these were direct from English public life in middle age, also strengthened the influence of English women upon Calcutta society, for with few exceptions they brought their wives with them. And as in all ages and in all climates, the wives proved more orthodox, conventional and socially conservative, than the husbands. The number of Europeans in Bengal who had Indian wives or mistresses was still large, but their pattern of life became noticeably less socially acceptable. The growing numbers of European wives belped to make the British community a nore closed one, from which Indians and Indian influences were excluded. The missionary William Carey regretfully noted in his journal for 17

1. Eric Stokes, The English Utilitarians and India, p. 3 et seq. 
February 1795,

"I have to complain of abundance of Pride; which I find it necessary to opose, and the more as my blaming me for putting myself on a level with the Natives." I The closeness of the ties between the British service families which developed in this period also strengthened the closedness of British society in Bengal: men were not the servants of some anonymous bureaucrady, but members of a network of kinship ties and subject to the social control of that network. ${ }^{2}$ The sense of belonging to a band of brothers was further reinforced by the establishment at the turn of the century first of the College of Fort William and then of Haileybury. These institutions bad a qutte practical, utilitarian purpose, but they also served social ends. The young writer in Calcutta was no longer left at the mercy of banyans, but was placed under English supervision for their "studies, manners, morals, expenses or conduct." 3 The Provost of the College of Fort Villiam was always a clergyman of the Church of England, and as Tellesley's minute of 18 August 1800: shows, he was expected to assist his charges with advice and admonition and to

1. Journal of William Carey, 17 February 1795, p.125. 2. Supra, Ch. III.

3. Hinute of Wellesley in Council at Fort William, 18 August 1800 in Claudius Buchanan, editor, The College of Fort William in Bengal, p.12. 
instruct them in the principles of the Christian religion according to the doctrine of his Church. I A similar concern was shown for the candidate for the Company's service at Haileybury, the Comittee of Correspondence which considered the functions of the College in 1804 stressing that without a full attachment to the principles and truths of the Christian faith, the young civilians could not fulfil their trust either to Great Britain or to India. ${ }^{2}$ Both Fort William College and Haileybury thus added a noral purpose to practical training - but they also added to the closeness of the social ties between members of the Company's service - and were meant to do so. The Haileybury Committee of 1804 saw Ereat advantage in ensuring that candidates would be initiated "in one uniform system of right principles", but also stressed the value of sending out young civilians who wene already acquaintances and friends, and who would thus share a sense of identity amone the millions of alien subjects over whom they would rule. ${ }^{3}$

Two results of these general changes in the pattern of European society in Bengal in the late eighteenth

1. Ibid., pp. 26-7.

2. Eubree, op.cit., p.198.

3. Ibid., p.199. 
century are to be noted: the first a rejection of some Indian customs earlier adopted, the second a response to changes in English society. Thus one can note a decline from favour of the habit not of smoking but of smoking the hookah. Questions were raised as to whether it was hygienic, and complaints boiced that public and private assembly rooms were filled with its vapours, to the detriment of those who indulged in the violent exercise of dancing, and needed fresh air to respire. 1 Others suggested that for ladies to smoke the hookah was in very dubious taste: such a sight, one correspondent reported, "excited such ideas in my mind, which disordered my imagination to a strange degree." 2 By the mid-eighties of the eighteenth century, the hookah was being banished from assembly rooms, ${ }^{3}$ and frowned upon even in private: in 1797 Captain Griffith, nephew and aide de camp of General Alured Clarke was sharply reproved by the general for indulging in "this useless, if not an offensive thing". 4 The condemnation of the hookab was also taken up by the

1. The India Gazette, Calcutta, 9 December 1780, No. 4. 2. Benal Gazette, Calcutta, 28 April to 5 May 1781, 3. Calcutta Gazette, 8 November 1792. Seton-Karr, op.cit 4. Hickey, op.cit., Vol. 4, p.168. 
press, with increasing sharpness, and though some old nabobs clung to their hookahs - Lord Nugent for example in 1812 found half bis guests at public breakfast arriving armed with hookahs, much to Lady Iugent's annoyance ${ }^{1}$ by the 1870's the habit had been entirely abandoned. ${ }^{2}$ One contributory reason, of course, was that the habit was expensive, for to keep a hookab also presupposed the maintenance of a servant, the hookahbardar, to prepare it. The taste for the nautch was another victim of the Anglicisation of Calcutta society - and particularly perhaps of the coming of nore English wives. The attitude of the French observer Le Couteur was doubtless a common one, when in 1785 he wrote of Calcutta:

"It is at tisis place that we saw, for the first time, the dancing girls which are so much talked of. The accounts given of their beauty and graceiul attitudes are highly exageerated: they are in reality inferior in point of beauty to many other women of the country, and in their dancing I was not able to discover the least Erace or elegance of motion." 3

Since the nautch was often offered as an entertainment of European guests by the native gentry, Hindu and inslim, 4 it was tolerated, but no rore: Tennant advised

1. Lady INugent, op.cit.,Vol. I, p.107.

2. Busteed, op.cit., p.143.

3. Le Couteur, op.cit., p.334.

4. Lady Iugent, op.cit., Vol. 2, p.249; Maria Graham, op.cit., pp. I34-5;- D'Oyly, op.cit., Plate 14. 
in 1797 that "they should be accepted with at least an appearance of satisfaction." I It was up country, in the masculine society of the military stations, where the disapproval of English wives was not yet felt that the noutcn girls were still trequently invated to display their skill and charms. 2

The abandonment of Indian customs was but the reflex of a wider conformity to English manners. These manners were themselves changing, however, in the last decades of the eighteenth century, and in Bengal the changes in England can be seen reflected. Two movements were afoot in England, one unplanned the other purposeful - the Industrial Revolution and the Evangelical movement - which both set rorward new social values. 3 she Industrial Revolution created a new class of men with power and authority to set besides the old aristocratic, landowning leadership, and where the latter had depended upon inheritance in a fixed hierarchical society, and had set an example of grand, even extravagant living, the new men

1. Tennant, op.cit., vol. 1, p.56.

2. D'OrIy, op.cit., plate 15.

3. See Introduction to Ihriel Jaeger's Before Victoria, pp. ix-xi. 
rose by personal effort, by hard worl and by frugality. A new economic order developed a new code of social values and behaviour in answer to its unspoken need. ${ }^{1}$

Contemporaneously a religious revival affected England, which though it had its starting point in Vital Religion, in personal conversion, also served to promote such social virtues as frugality, sobriety and industry. Among the lower orders of society it was liethodism which was active, and Dr. Priestly ascribed to it "the civilization, the industry, and sobriety of great numbers of the labouring part of the comrunity." 2 Among the upper classes, the impulse was provided by the Ivangelicals and by such persons as Hannah Hore. They numbered in their ranks men such as IIilner of Queen's College or Simeon of Xing's College, Cambridge, the merchant Zachary Hacaulay, Wilberforce, M.P. for York, Henry Thornton the banker and James Stephen the lawyer, ${ }^{3}$ men of the class from which many Company servants were drawn. It was one of their number, Wilberforce who in 1787 persuaded George III to issue a royal Proclamation against vice and immorality, calling

1. For the social consequences of the Industrial Revolution see Ch. II in Plumb, op.cit., p.84 et seq.

2. Briggs, op.cit., p.69.

3. Ibid. 
for the due enforcement of the laws against Sabbathbreaking, swearing, licentious publications and unlicensed places of public amusement. Vilberforce followed this up with the formation of a Proclamation Society to follow up the royal lead. 1 At this time Hannah liore became associated with $7 i l b e r f o r c e$, and in 1788 she published anonymously her "Thoughts on the Importance of the Manners of the Great to General Society." Her appeal to the higher orders to set the moral tone for society ran through seven large editions in a few months. This was folzowed by her Estimate of the Religion of the Fashionable vorld, in 1790, which earned her the title of the "Bishop in Petticoats", and ran through five editions. ${ }^{2}$ In 1793 Vilberforce and Hannah IIore gathered round Joseph Venn, Rector of Clapham and were there joined by Charles Grant, by Sir John Shore, Stephen, Thornton, liacaulay and others. ${ }^{3}$ These Claphamites were perhaps social conservatives in their acceptance of the order of society, but they were radical in their determination to secure a reformation of manners and a new

1. Robert Isaac and Samuel Vilberforce, The Iife of Wilberforce, Vol. I, p.129 et seq.

2. See Chapter V in IH.G.Jones's Hannah More, pp. 103-21.

3. Sir Reginald Coupland, Wilberforce, pp. 202-3 
righteousness in the upper ranks of society. 1 All these ideas had their effect upon European society in Bengal, for the ties with India both of the commercial and manufacturing classes and those directly affected by Evangelical teaching were close. 2

In the nineteenth century it was often declared that India had become the preserve of the British middle class: there are clear signs that midale class morality Was being imposed on Bengal society even in the eighteenth century. One example of this is to be noted in the improvement of Sunday observance in Calcutta. St. Anne's Church founded by subscription in $1715^{3}$ had been destroyed in 1756 by Siraj-ud-daulah4 but for thirty years it was not replaced. In 1774 lilackrabie recorded:

"One of the first observations we made here was, that they have no church. The same Edifice served upon the first day of the week for the Celebration of divine serviee, and during the other six for the purpose of entering of Goods and Collecting of Customs. The Conpany's Servants were much amazed to see us go thither in a Body the sunday after our arrival." 5

1. Watson, op.cit., pp. 353-5.

2. One might note for example the example of an Inglish woman in India who in 1809 was commenting "from what we heard, we supplosed that since we had left England, the cool green island had become a land of saints." Quoted in Briggs, op.cit., p.72.

3. J.H.Grose, A Voyage to the East Indies, 1750-64, Vol.2, p. 237; Capt. Alexander Hamilton, A New Account of the East Indies, Vol. 2. p.II.

4. Asiaticus (Hawkesworth), op.cit., p. 5 .

5. Iss. Eur. E25, p.53. 
In 1770 a missionary church rather rudely furnished was established by the Swedish missionary John Zachariah Kiernander in Calcutta, with services in English and Portuguese, but this was dismissed by the European community as "fit only for stable boys and low Portugeuse."l The religious laxity and contempt for vulgar missionary enthusiasm characteristic of the English upper classes in the later eighteenth century ${ }^{2}$ were thus faithfully reflected in Bengal. But the religious revival in England, given expression for example in George III's procalamation also had its counterpart in Bengal. In the early eighties a movement was set on foot for building a church by subscription, ${ }^{3}$ and in $1787 \mathrm{St}$. John's Church was completed and consecrated. ${ }^{4}$ Cornwallis set an example of observance of the Sabbath by his regular attendance at St. John's. 5 Both Sir John Shore and Wellesley fully maintained the

1. Lewis, op.cit., pp. 29-30.

2. Dorothy Marshall, "Hanners,. . . Pastimes" in Turberville, op.cit., Vol. I, p.359.

3. Teignmouth, op.cit., Vol. 1, p.194

4. The foundation stone of the Church was laid in 1784 by Edward Wheler (See List of Inscriptions on Tombs or lionuments in Bengal, ed. by C.R. Wilson, p.73) but it took three years to complete the building. In 1788 Thomas Daniell sketched it (See plate 58, in Calcutta Faces and Places in Pre-Camera Days, ed. by Vilmot Corfiela, p.43).

5. Lewis, op.cit., p.3I. 
tidadition Cornwallis had founded. ${ }^{1}$. Dr. Plumb has comented on the results of Hethodist evangelism in England, "prudish piety began slowly to replace that frank cynicism which had been the hall-mark of eighteenth century fashion" ${ }^{2}$ - the same change, whether to be applauded or deplored, was under way in Bengal.

At much the same time attacks upon gambling gathered force. In 1784 a correspondent to the India Gazette wrote,

"I do not know a species of vice that calls more loudly for animadversion and correction than the destructive passion of gaming. It seems congenial to the soil of India... The prevalence of this destructive vice, particularly among the younger part of the English inhabitants of India, seems to require from the forcible hand of Government an immediate check." 3

Iith Cornwallis as Governor-General, and men like f'rancis, Barwell or Fowke no longer in office, the required check was administered. Cornwallis made known his strong disapproval of gambling, and he refused to appoint or promote to offices of trust and responsibility men who were known

1. Up country the Sabbath was ignored nuch longer. In 1798 the Directors were complaining that horse races were being run on Sunday at the military stations (See Despatches to Bengal, 25 Ilay 1798, Para. 71 in D.B., Vol. 32, pp. 398-401) and in 1802 the young Charles Metcalfe commenting on religious laxity, noted "For the want of this, the English in India have less virtue in them than elsewhere, and can not impress the natives with a good idea of our religion." Quoted in Thompson, op.cit., p. 30 .

2. Plumb, op.cit., p.160.

3. The India Gazette, Calcuita, 21 February 1784, 
to indulge in gambling. ${ }^{1}$ His actions reduced gambling to a small set in Calcutta, and gambling on the old scale was further diminished when the Directors in 1798 issued strict orders to Wellesley to detect those persons who engaged in gaming, and to remove them from office and ship them back to England. 2

Cornwallis went beyond his move against gaming to a more general attack upon extravagance. He refused to adopt an aristocratic style of living for himself, and showed himself ready to discourage it in others. "I am doing everything I can to reform the Company's servants," he wrote to Dundas, "to teach them to be more economical in their mode of living and to look forward to a moderate competencey". 3 He set an excellent example of frugality himself.

"Son extérieur est très simple", wrote Charpentier Cossigny de Palma, "Je ne l'ai jamais vu qu'en uniforme; il ne va jamais qu'à deux chevaux et sans [sic] cortège .... rarement visite-t-il quelques-unes des principales femmes 1. The India Gazette, Calcutta, 21 Hebruary 1784, Vol. 4,

2. Despatches to Bengal, 25 May 1798, Para. 80 in D.B., Vol. $32, \mathrm{p} .417$. Gaming now seems to have become confined chiefly to the Captains and officers of the Indiamen. In 1804 George tlers recorded an instance where he was "pressed ... to play a game" with a captain of an Indiaman, who lost after three days, twenty thousand rupees to him. See Hemoirs of Geore Elers, ed. by Lord Iionson and $G$. Leveson Gower, pp.

3. Cornwallis to Dundas, 26 August 1787. Ross, op.cit., p. 278 . 
de la ville, ne mange chez peŕonne, tient une table assez frugale et peu nombreuse, et he donne jamais que les fêtes de devior chez les Anglais"l

This tradition Shore followed, but Wellesley decisiriely abandoned. Cornwallis was sure of bis place in English society and of popular respect, and could afford to be simple and unaffected in his way of life. Wellesley on the other hand was an Irish social climber, out to impress by the magnificence of his style and his autocratic manner. 2 He cailed however to carry Calcutta society from the sober middle class course on which Cornwallis ${ }^{3}$ and shore had set it: Wellesley consequently labelled it dull, and denounced its "stupidity and ill-bred familiarity." 4

As Dr. Spear has pointed out, Cornwallis also frowned upon public dancine, discontinued after 1786 the custonary Christmas dinner, ball and supper, and greatly curtailed the entertaining at Goverment House. 5 For the traditional breakfasts, open to almost anyone of respect-

1. Charpentier Cossigny de Palma (Joseph Frangois), Voyage au iol Bengale... fait en 1789, $\mathrm{fol}$. I, pp. 42-3.

2. George III himself complained that Wellesley demanded ceremonious respect from those about him much beyond what was due to his station. See George Rose's Diaries quoted in P.E. Roberts, op.cit., p.73.

3. Charles Raikes in The Englishman in India, hails the coming of Cornwallis as a bright day for the British society in Bengal ( .211 ) and Héry Morris in his Governors-General of India judges one of Cornwallis's chief nerits as raising its tone in Calcutta (pp.34, 46).

4. Spear, op.cit., p.65.

5. Ibid. 
bility he substituted open levées. I Some of the older, senior officials continued the practice of maintaining a public breakfast table for some years loneer ${ }^{2}$ - Lora Nugent was one such, for example - but the practice had died out by the end of the century. This move away from open handed hospitality was inevitable as frontier settlement gave way to imperial capital, ano inevitable, too, when the swolien fontunes of the nabobs became the cometencies of civil servants. Hospitality to strangers, to the newly arrived cadets and writers from home, had been eneral, and had been much acmired and commented upon: Forbes for example declared "the character of the English in India is an honour to their country; in private life, they are generous, kind and hospitable." ${ }^{3}$ (Joseph Price, after thirty years in India, suggested that peraps the honour was due to India: "Universal charity, and general hospitality, are natives of Asia, and are practised by the Hindoos towards all straneers, as far as their customs and religious prejudices will admit. Young minds are attracted by exmple; and it is the ceneral opinion, what it in any part of the world, Englishmen are pre-

2. Wiliamson, op.cit., vol. 2, pp. 126-7.

2. Ibid.

3. Forbes, op.cit., vol. I, p.154. 
eminently famous for the social virtues, the Companyls servants in the wast Indies are they." $)^{I}$ While numbers were few, and loneliness and homesickness inevitable, eneral hospitality was natural: as the European community grew, and became sslf-sufficient, however, the circle of hospitality could become narrower and more selective. While government entertainuents were being restricted, and private hospitality was becoming less open-handed, there was also a growing decorum and refinement. The newspaper reports of the public dinners and private parties of Hastings's day show them to have been frequently extremely disorderly, ${ }^{2}$ and liackrabie records that even private occasions were "little Riots, Thirty people at Brealfast - Iitty at Dinner - supper at liidnight Dances till Daylight." 3 Heavy drinking and much horseplay had also been the order of the day. At least one custom, described by Hickey as "fitter for savages than polished society", that of flicking bread pellets about the dinner table, seems to have come to a sudden end. Hickey reports that a Captain lorrison let it be known at one party that if any one flicked bread pills at bin, he would consider

1. Price, o.cit., p.20

2. Benal azette, Calcutta, 3 to 10 November 1781, No. 3. MSs. Lur. 225, p.59 
it ar insult and resent it accordingly. He had scarcely made his statement when he was hit full in the face by a peliet. His reply was to seize a plate bearing a leg of mutton and aischarge it at the offender, a new arrival from Iondon, knocking hin out of his chair. The inevitable duel Pollowed, in which Horrison shot the pelleter through the body, inflicting a wound which kept him in bed for several wonths, and from which he never fully recovered. If, Hickey is to be trusted, Morrison's action effecturly discouraged the bread pellet habit.

The more barbarous custom of "sitting up", where newly arrived ladies were displayed as marriageable objects before the colony, also disappeared. In 1781 a correspondent to the India Gazette complained that it was wounding to the sentiment to see someone's sister or daughter thus exhibiting berself for severel nights before a crowa of unknown persons. ${ }^{2}$ Hickey denounced it as a "disagreeable and foolish ceremony", 3 and Williamson later compared it with "the exhibition of a cargo of slaves." ${ }^{4}$ The growth ol Calcutta, with houses scattered over a wider and wider

1. Hickey, op.eit., Vol. 2, p.137.

2. The India Gazette, Calcutta, 28 April 1781, No. 24. 3. Hickey, op.cit., Vol. 3, pp. 159-60.

4. Williamson, op.cit., Vol. 2, p.113. 
area, made the custom in any case unpracticable, and by the late 1780's it had virtually disappeared. ${ }^{1}$ lifore decorous ways for making introductions followed the ball offered by captains of the East Indiamen on arrival at Calcutta, ${ }^{2}$ the irequent little parties such as Hargaret Fowke hoped to arrange, ${ }^{3}$ the salons which Roberdau noted in 1805 "a kind of levee held once a week by three or four of the head ladies in the settlement" 4 and the like. The change in the nature of the settlement can also be traced in the fortunes of the theatre at Calcutta. The play had always been a great social attraction Nackrabie notes in his journal that addicts would travel the twenty one miles to Chandernagore to see a French play at the weekend ${ }^{5}$ - and the creation of a Calcutta theatre by subscription has already been described. Unfortunately after the departure of the first manager of

1. Ibid., p.114.

2. Hajor J. Blakiston, Twelve Years IIIlitary Adventures in Hindustan, vol. $1, \mathrm{pp} .48-9$.

3. Hargaret Fowke to her brother, Francis, 23 April 1783 Iiss. Eur. E.4 Fowke Iiss K.24, p.42.

4. A young Civilian in Bengal, 1805, Journal of the Calcutta Historieal Society, op.cit., p.124.

5. Hiss. Eur. E. 25, p.104. 
the Calcutta theatre, Rundell, the finances of the theatre were allowed to fall into disorder. ${ }^{1}$ There was $£ I, 500$ yearly to be paid in interest at twelve per cent upon the original cost of $£ 12,500$, there were new costumes to be bought, suppers and complementary tickets to be provided for the players. ${ }^{2}$ But an even greater problem was that the theatre was in effect an amateur one. Rundell had engaged three actresses from London, ${ }^{3}$ but most of the parts were taken by amateurs. The standard of acting was not very high: Irs. Fay declared that "many go to see a tragedy for the express purpose of enjoying a laugh," 4 and it was not possible to put on wore than about ten pieces each cold season, not all of which would attract a full house. ${ }^{5}$ Cornwallis added the wight of his strong displeasure at persons in the Company's service taking part in the plays, ${ }^{6}$ and ultimately the theatre was closed and sold to a member of the Tagore family. With the addition

1. The World, Calcutta, 19 IIIay 1792, Vol. I, No. xxxil; Hickey, op.cit., vol. 3, p.209.

2. Williamson, op.cit., Vol. 2, p.202.

3. Hickey, op.cit., p.209.

4. Lrs. Fay, op.cit., p.194

5. The World, Calcutta, 10 December 1791, Vol. I, No.1x; Williamson, op.cit.

6. Villitamson, op.cit., p.203; Grandpré, op.cit., Vol.2, p.4; A Young Civilian in Bengal in the Journal of the Calcutta Historical Society, op.cit., pp.117-8. 
of various new buildings the theatre was converted into the New China Bazaar. ${ }^{1}$

Amateur theatricals were kept alive in private households, Mrs. Bristow the wife of a senior merchant of the Company bad a private theatre in her Chowringhee house and herself took part in performances ${ }^{2}$ until she left Bengal in 1790, 3 and they remained very popular in up country stations and cantonments. 4 But in Calcutta, the theatre became professional. In 1795 a Russian Herassim Iebedeff opened a theatre in Dharmatallah where English plays were staged as well as Bengali versions performed by Beagali actors and actresses. 5 In 1797 another theatre was opened at Wheler Place, the present Government Place North, and yet another, the Athaneum, at No. 18 Circular Road. 6 Calcutta had ceased to be an intimate Company's station and had become a city.

1. Carey, op.cit., Vol. 1, p.132.

2. Calcutta Gazette, 29 October 1789. Seton-Karr, op.cit Vol. 2, pp. 234-5.

3. Supra, Ch. IV.

4. Williamson, op.cit., p.205.

5. B. V. Roy, op.cit., p.125.

6. Ibid., p.127 
As befitted a city, in 1792 proposals were voiced for builaing a Town Hall. Hitberto all social gatherings had been held either at the old Court House ${ }^{l}$ or at the Harmonic Tavern, ${ }^{2}$ both by this date in need of repair. ${ }^{3}$ on 31 llay 1792 a meeting of the British residents of Calcutta, held at Le Gallais' Pavern, resolved to defray the expenses of a public building for the general accommodation of the settlement. The building was to contain a spacious ballroom, a concert room, dining rooms, card rooms, dressing rooms and other necessary facilities. It was also to include suitable offices, and was to be provided with separate entrances for palanquins and carriages, with detached sheds for the vehicles and horses. ${ }^{4}$

1. Hyde, op.cit., pp. 90, 160-2.

2. Hart, op.cit., p.28.

3. The World, Calcutta, 26 ITary 1792, Vol. 1, No. xxxiii; Blechynden, op.cit., p.115.

4. Calcutta Gazette, 5 July 1792. Seton-Karr, op.cit., Vol. 2, p.538. 
The building was completed in $1814,{ }^{1}$ a proper monument to civic pride.

If the superficial borrowings from Indian life such as nautch and hookah began to decline in the last decade of the eighteenth century making room for a more Anglicised and more refined society in Bengal, the interest in Indian studies by a snall band of the servants of the Company became ascendant thereby completing the picture of a cultural life of the society. This aspect of the social life of the British community in Bengal requires som coment before we close our discussion of the subject.

1. Carey, op.cit., Vol. 2, p.146. S.C.Sanial in an article in the Journal of the Calcutta Historical Society advances a different view about the origin of the Calcutta Town Hall. According to him the British inhabitants of Calcutta decided in two meetings, held respectively in 1799 and 1804 to erect marble statues of Cornwallis and Wellesley and appointed a comittee of some important persons to carry out their resolutions. As it was not safe to place marble statues in the open air in a climate like that of Bengal and as there was no suitable building to house them at Calcutta, the Committee suggested to the government in the following year, the expediency of constructing a Town Hall for the reception of the statues, out of funds to be raised by means of public lotteries (See S.C.Sanial, "The Calcutta Town Hall" in the Journal of the Calcutta Historioal Society, 1914, Vol.9, No.18 p.181). This view has been repeated by Cotton who seems to follow Sanial blindly $(p .729)$ but it is completely wrong. The meeting to discuss the building of a "lown Hall was held in 1792 and its purpose was not to house the statues of Cornwallis and Fellesley but rather to create a social centre for Calcutta. The object of housing the statues of Cornwallis and Wellesley may have been added later to the original plan to enlist the support of the government. 
The evidence of the inventories preserved in the Hayor's Court and the Supreme Court at Calcutta shows that there had always been a number of persons whose interests extended beyond administration, outdoor sport, gaming, balls and similar amusements. Individual collections of books ranged from Plutarch to Locke, Hobbes, Voltaire, Montesquien and Rousseau, from Thucydides to Orme, from the Arabian Nights to Henry Fielding and from Shakespeare to Iilton. There was also a fair range of scores, Bach, Handel, Corelli and Herschel. 1 The newspapers always contained some advertisements for books, and also for musical instruments. 2 By the late 1780 's there were literary clubs and circulating libraries, the latter to be found in Berhanpur, Dinapur and Cawnpur as well as at Calcutta, ${ }^{3}$ and in Calcutta the Catch Club was founded as a protest asainst the "rattling chatter and noise" at the Harmonic, where the audience paid no attention to "the sweet strains of Corelli and other famous composers", to the great annoyance of real music lovers. ${ }^{4}$ In 1788 we

1. See Appendix B in Dr. Spear's "The Nabohs, pp. 189-91.

2. Calcutta Gazette, 7 October 1784. Seton-Karr, op.cit

3. Calcutta Gazette, 21 February 1788. Ibid., pp.281-2. 4. Hickey, op.cit., Vol. 2, pp.162-3. 
hear of a concert for the benefit of $1 \mathrm{Ir}$. Oehme ${ }^{l}$ and in Harch 1797 a series of three classical concerts devoted to the works of Handel. 2

Concerts of European music and libraries of European literature might be accepted as the obvious solaces of the exile in a distant land, the links with home which the slow passage round the Cape otherwise made very scanty. 3 of greater interest therefore is the growth of a European interest in oriental studies. This had been growing, both in England and in India ever since the middle of the eighteenth century. John Swinton wrote the Indian Section for the Universal History in 1759, and in 1763 Robert Orme, the historiographer of the East India Company published his History of the Iilitary Transactions of the British Nation in Indostan and Alexander Dow's The History of Hindostan in 1768-72.4 These works were followe

1. Calcutta Gazette, 7 February 1788. Seton-Karr, op.cit., Vol. I, p.281.

2. Calcutta Gazette, 9 Inarch 1797. Ibid., Vol.2, p. 468 et seq.

3. Hunter comments that the library of Frushard, the founder of a silk filature in the wilds of Birbbum, included six volumes of the first edition of Gibbon a solid solace to a very isolated exile. Hunter, op.cit., p.367.

4. J. S. Grewal, British Historical Writing... on Iruslim India, London Ph.D. thesis (1963), p. 45 et seq. 
with Varren Hastines's encourasement ${ }^{l}$ by Nathaniel Halhed's A Code of Gentoo Laws in 1776 and Bengali grammar in 1778, 2 and in 1779 by Charles filinin's Sanskrit grammar and by Francis Gladwin's Institutes of the Enperor Akbar in 1783.4 These were but the first, to some degree utilitarian steps, 5 and the linguistic difficulties were still formidable - it may be noted that Dow's History, Halhed's Code and Gladwin's Institutes were translated into English from the Persian. Iittle reputation was acquired by the immense labour of editing and translating texts, and the costs of publication were still daunting. 6 Iioreover the efforts made were still isolated, there was no organised attempt to uncover ancient aid madiaeval India and make it known to the world. Nevertheless those who translated, and Hastings who encouraged, had a renuine interest in Indian and Indo-Persian culture

1. Hastings to the Court of Directors, 1774, quoted in Feiling, op.cit., p.56

2. Bucklana, op.cit., p.185

3. Ibid., pp.451-2.

4. Ibid., pp. 166-7.

5. C.H.Philips, "James lilil, Hountstuart Blphinstone, and the history of India", in Historians of India, Pakistan and Ceylon (edited by C.H. Philips), pp.217-8.

6. Teiennouth, op.cit., Vol. I, pp. 103-4. 
and the wish to explore and interpret it. Hastings, in sending a copy of the Code to Lord liansfield, offered it "as a proof that the inhabitants of this land are not in the savare state in which they have been unfairly represented." I

With the arrival of Sir William Jones in Calcutta, in September $1783,{ }^{2}$ a new impulse, and a new organisation was given to Indo-British orientalism. Jones was already an accomplished Persian scholar, whose Grammar of the Persian Language and translations of the Persian poets, published in 1771 and 1773, had won hit a European reputation. ${ }^{3}$ He now applied his own enthusiasm to the organisation of scholarly effort in Beneal. But he soon realised that without the "united efforts of nany" 4 he could not achieve his ambition of knowing India "better than any other Luropean ever lnew it" (as he later said to Lord Althor $\left.p^{5}\right)$. He had been elected a fellow of the Royal

1. Quoted in P. Moon, Warren Hastings and British India, pp. 348-9.

2. Sir John Shore, liemoirs of the Life, Uritings and Correspondence of Sir irilliam Jones, p.232.

3. Ibid., p.91 et seq.

4. Asiatick Researches, Calcutta, 1788, Vol. I, p.x.

5. A. J. Arberry, Asiatic Jones, p.23 
Society in London in 1773 and he set out to create a similar learned society in Calcutta, with as its aims "enquiry into the history and antiquities, arts, sciences, and literature of Asia." ${ }^{1}$ Not lone after his arrival in Bengal he addressed a meeting of thirty Englishmen, the élite of Calcutta society, in the Grand Jury room of the Supreme Court, under the presidency of Robert Chambers, the Chief Justice and an old fellow of University College, Oxford. Jones asked his audience to utilise their leisure hours in learning to know Asia, "the nurse of science, the inventress of delightful and useful arts, the scene of glorious action, fertile in the production of human genius, abounding in natural sonders, and infinitely diversified in the forms of religion and government, in the laws, manners, customs and languages, as well as in the features and complexions of men." 2 History, science and art, be summoned them to the study of all three, ${ }^{3}$ and on 15 January 1784 the "Asiatick Society" of Bengal was formed to pursue these aims. Varren Hastings and the members of the Supreme Council acted as pationstir William Jones as president and J.H.Harington as secretary of the Society, ${ }^{4}$ the

I. Ibid., pp.20-21.

2. Asiatick Researches, Calcutta, 1788, Vol.1, pp.ix-x. 3. Ibid., pp. xiii - xiv.

4. Ibid., pp. 439-440. 
foundation of humanistic study of "Man and Nature"l in Bengal.

In the beginning the Society had no formal rules - its only rule, as Jones said, was "to have no rules at all There was no subscription fee, no restriction about membership, so that anyone interested in oriental studies could join. ${ }^{2}$ Such an attitude was necessary, Jones nust have believed, for the careful nursing of an infant institution. Ten years later when membership had risen from thirty to one hundred and twenty three ${ }^{3}$ it seemed necessary to have some rules to guide the Society's affairs and accordingly a comittee was appointed to discuss the problem. On 29 september 1796 the comrittee suggested that application should be made through the Governor-General to His Iiajesty for a charter of incorporation; that a house should be built large enough to accomodate the weekly meetings of the members and to house the museum and library of the society; that a Committee of Papers should be elected annually to judge and select papers for publication in the Society's journal, and that an admission fee of two gold mohurs and annual subscription of four Eold mohurs should

1. Ibid., pp. xii - xiii

2. Ibid., pp. xv - xvi

3. Ibial., Calcutta, 1795, Vol.4, pp. 439-440. 
be charged, while voluntary contributions to the new building should also be invited. ${ }^{l}$ The Society had already been accepted into the international world of scholarship by 1792 for example there were coments arriving from Einburgh University on a mathematical article in the Soceity's journal ${ }^{2}$ - and with its reorganisation it clearly passed from infarcy into enthusiastic and active youth. Between the Society's foundation in 1784 and the close of the century, contributions to the Asiatick Researches" had come from Bombay, Madras, Burma and Ceylon as well as Bengal, ana from a very varied body of contributors, ranging from Colonel Pearse, in the Bengal Army since $1768,^{3}$ to Reubon Burrow, eaitor of the Royal Almanac until he went to India in 1782 at the age of thirty five. 4 The range of topics treated was no less wide. Wilkins, 5 Chambers, 6 John Sbore, ${ }^{7}$ Burrow, ${ }^{8}$ Jones, 9 Ensign Blunt, 10

1. Ibid., Calcutta, 1799, Vol.6, p.590 et seq.

2. Ibid., Calcutta, 1795, Vol. 4, p.159

3. Buckland, op.eit., p.33I.

4. Ibid., p.64.

5. Asiatick Researches, Calcutta, 1788, Vol. I, p. 123 et seq.

6. Ibid., p. 145 et seq.

7. Ibid., Calcutta, 1790, Vol. 2, p. 383 et seq.

8. Ibid., p. 477 et seq.

9. Ibid., Calcutta, 1792, Vol. 3, p. 39 et seq.

10. Ibia., Calcutta, 1795, Vol. 4, p.313 et seq. 
Goldinghan, ${ }^{2}$ Duncan ${ }^{2}$ and lifalet ${ }^{3}$ all contributed to the study of various aspects of Indian antiquities; Davidson 4 and Colebrooke ${ }^{5}$ studied coins, veights and measures; Wilford ${ }^{6}$ and Jones ${ }^{7}$ tackled the problem of Indian chronology; Jones, ${ }^{8}$ Hajor Roberts, ${ }^{9} \mathrm{Dr}$. Buchanan ${ }^{10}$ and Blaquiere $^{11}$ engaged in linguistic studies and Turner, ${ }^{12}$ Wilkins ${ }^{13}$

1. Ibid., Calcutta, 1797, Vol. 5, p.69 et seq.

2. Ibid., p. 131 et seq.

3. Ibid., p. 135 et seq.

4. Ibid., Calcutta, 1790, Vol. 2, p. 331 et seq.

5. Ibid., Calcutta, 1797, Vol, 5, p. 91 et seq.

6. Ibid., Calcutta, 1788, Vol. 1, p.369 et seq.

7. Ibid., Calcutta, 1790, Vol. 2, p.389 et seq.

8. Ibid., Calcutta, 1788, Vol. 1, p. I et seq.

๑. Ibid., Calcutta, 1797, Vol. 5, p. 127 et seq.

10. Ibid., p. 219 et seq.

11. Ibid., p. 371 et seq.

12. Ibid., Calcutta, 1788, Vo1. 1, p.199

13. Ibid., p. 288 et seq. 
Jones, ${ }^{1}$ Colonel Pearse, ${ }^{2}$ Shore, ${ }^{3}$ and Duncan ${ }^{4}$ concerned themselves with religion and popular manners and customs. Colonel Pearse, ${ }^{5}$ Burrows, 6 Jones, ${ }^{7}$ Balfour ${ }^{8}$ Lieutenant Colebrooke, ${ }^{9}$ Capt. Wilford 10 and Lieutenant Lambton ${ }^{11}$ studied Indian mathematics, Colebrooke ${ }^{12}$ geology, Jones ${ }^{13}$ and Baog ${ }^{14}$ zoology, Lieutenant Hamilton, ${ }^{15} \mathrm{Jones}^{16}$ and Dr. Roxburgh ${ }^{17}$ botany, Turner, ${ }^{18}$ Hunter ${ }^{19}$ and Colebrooke 20

1. Ibid., p.415

2. Ibid., Calcutta 1790, vol. 2, p.333 et seq.

3. Ibid., Calcutta, 1795, vol. 4, p. 331 et seq.

4. Ibid., Calcutta, 1797, vol. 5, p. 1 et seq.

5. Ibid., Calcutta, 1788, vol. 1, p. 57 et seq.

6. Ibid., p. 320 et seq.

7. Ibid., Calcutta, 1790, vol. 2, p.289 et seq. 8. Ibid., Calcutta, 1795, vol. 4, p. 195 et seq.

9. Ibid., p.321 et seq.

10. Ibid., Calcutta, 1797, vol. 5, p.241 et seq.

11. Ibid., Calcutta, 1799, vol. 6, p.137 et seq. 12. Ibid., Calcutta, 1797, vol. 5, p.303 et $s \in q$. 13. Ibid., Calcutta, 1795, vol. 4, p.135 et seq. 14. Ibid., Calcutta, 1799, vol. 6, p.103 et seq. 15. Ibid., Calcutta, 1788, vol. I, p.306 et seq. 16. Ibid., Calcutta, 1790, vol. 2, p.345 et seq. 17. Ibid., Calcutta, 1795, vol. 4, p.356 et seq. 18. Ibid., Calcutta, 1788, vol. 1, p.206 et seq. 19. Ibid., Calcutta, 1799, vol. 6, p.7 et seq. 20. Ibid., Calcutta, 1801, vol. 7, p.1 et seq. 
geography, Colonel Polier ${ }^{1}$ and It. Col. Martin ${ }^{2}$ economics and Jones, ${ }^{3}$ Elliot ${ }^{4}$ and Shaw ${ }^{5}$ ethnology. The range of subjects covered was wide, and under Sir William Jones's impulse, so was the area studied, from Italy and Greece, through Egypt, Persia, Arabia and India to China. However when Sir John Shore became Governor-General of Bengal and President of the "Asiatick Society" in 1795 he pressed the need to concentrate on Indian studies, Hindu and Iinslim ${ }^{6}$ and from 1796 intensive research on Indian subjects may be said to have emerged. If Jones was the father of oriental, Shore was the guardian of Indological studies.

It should be noted that this lenaissance in Bengal

- too oiten overlooked by those who have trumpeted the Bengali Renaissance of the nineteenth century ${ }^{7}$ - also saw

1. Ibid., Calcutta, 1788, vol. 1, p.332 et seq.

2. Ibid., Calcutta, 1792, vol. 3, p.475 et seq.

3. Ibid., Calcutta, 1790, vol. 2, p.1 et seq.

4. Ibid., Calcutta, 1792, vol. 3, p.17 et seq.

5. Ibid., Calcutta, 1795, vol. 4, p.45 et seq.

6. Ibid., Calcutta, 1799, vol. 6, pp. iii-vi.

7. Neither Amit Sen's Notes on the Bengal Renaissance nor Atul Chandra Gupta's Studies in the Bengal Renaissance nor Bijoy Bhattacharya's Bengal Renaissance had any slightest reference to the intellectual activities of the "Asiatick Society" in the last two decades of the eigteenth century. 
a co-operation of Indian with English scholars. The contribution of Sir William Jones was of prime imortance - his identification of the Sandracottus of Greek records with Chandragupta liaurya in Indian texts provided a key to Indian chronology, ${ }^{I}$ his authoritative pronouncements on family relationship of Greek, Latin and Banskrit gave a new impetus to comparative linguistics, ${ }^{2}$ his translation of Kalidasa's Sakuntala and of Jayadev's Gita Govinda and of llanu in his postbumously published Institutes of Hindoo $\mathrm{Iaw}^{3}$ unlocked India for Europe. But in his work Jones enlisted and depended upon the co-operation of the pandits, and in legal studies, as Derrett has shown, their co-operation remained for many years of great importance. 4

1. Asictick Researches, Calcutta, 1795, vol. 4, p. I

2. A. J. Arberry, Oriental Essays, p.83. A proper evaluation of Jones's contributions to the "Asiatick Researches" is jet to be made. S. Mukherjee's London Ph. D. thesis on Sir Wil iam Jones is, hawever, interesting in other details.

3. A. I. Basham, The Wonder that was India, p.5

4. J. Duncan I. Derrett, Sanskrit Iegal Treatises Compiled at the Irstance of uhe British p. 33 et seq. 
Even in the first volume of the "Asiatick Researches" the work of Ramalachan Pandit, ${ }^{2}$ of Radhakanta Sarman ${ }^{2}$ and of Coverdhan Kaul ${ }^{3}$ is to be noted. With Wilkins, who tramslated the Bhagavad Gita and the Hitopadesa, 4 Jones succeeded in producing a meeting of minds with Hindu India. It must be saia, however, that Sir William Jones and the "Asiatick Society" in their work were acting against the general trend of British society in Bengal. Those forces in England which, as have been seen, modified the social attitudes of the Luropean commuity in Bengal in the late eighteenth century - the forces released by the Industrial Revolution and religious revival - were not favourable to a continued growth of administration and enthusiasm for Indian culture. Indeed, as Embree has pointed out, Charles Grant saw in Jones an opponent whose views were dangerous and must be combatted. 5 In the event Grant's "Observations on the State of Society in India in 1792" 6 proved more influential than Jones's work * * *

1. Asiatick Researches, Calcutta, 1788, vol. I, p.357

2. Ibid., p.379 et seq.

3. Ibid., p. 340 et seq.

4. Basham, op.cit.

5. Embree, op.cit., pp. 148-50.

6. The mandscript exists at the India Office Iibrary. (See liss. Eur. T.93) and was published at Iondon in 1797. 
In the second half of the eighteenth century the social life of the British communty in Bengal is one in flux: it changed with the changing conditions in Bencal and in response to changes within society at home. Those forces in British social Iife in Bengal which were to crystalise in the nineteenth century have begun to assume definite form by the end of our period. x 
CONCLUSION 


\section{Chapter VII}

Before Plassey and Buxar, the Directors of that trading corporation, the East India Company, had been concerned to recruit young men mainly of their own class and background to staff their commercial establishments in Bengal. They could offer them an uncertain and exotic, lonely and often turbulently quarrelsome career in small outpost factory dotted across the Gangetic plain, or in the larger settlement round Fort William at Calcutta, with very modest pay but opportunities of private trade, under privileged conditions in India and in open competition with Asian merchants in the wider port-to-port trade between the Red Sea and China. These prospects, with perquisites and the proceeds of minor graft were sufficient to attract a steady stream of applicants, who often were related to the Directors of Proprietors, or to those who had earlier served the Company in India. The great bulk of the candidates seem to have come from Iondon and the Home Counties, as might be expected of a Iondon Company. Then, with the revolution in the Company's position in Bengal after 1765, there were opened to the Company's servants novel possibilities, by no means always fulfilled, of acquiring sudden fortunes, as merchants who 
commanded political power, as administrators, courted by zemindars and revenue farmers, and aspoliticians and soldiers managing court revolutions. The patronage of the Directors at once acquired a new value - a Bengal writership might be worth $₫ 3,000$ on the market, a writership for China even more. However the composition of the Court of Directors, the men who handled this newly lucrative patronage, did not suffer any corresponding change: the house list drawn up by those in office continued in the main to be accepted by the Proprietors, even in the face of very great efforts by individual groups to break the hold. Old ties and old manners of proceeding were not therefore necessarily set aside. An analysis of the use of patronage shows indeed an intensification of one established tradition among the Directors, that of providing for their own immediate families: the links between the city merchant and the shipping element and the Company's services in Bengal were greatly strengthened after 1757 . Not for that matter do claims for past family services, those of a Becher or a Palk for example, seem to have been set aside either. The Writers' Petitions and Cadet Papers and Registers show a very considerable continuity between the pre - and post - Plassey periods, in the names of those going out to India. 
Such changes as did take place developed fairly slowly, with the growth of the Indian interest at the expense of the Shipping and City interests in the Directorate on the one hand and the development of closer ties between the Company and Parliament on the other. Even at the end of our period the largest single block of candidates are those from Iondon and the Home Counties, the traditional recruiting grounds for the Compang's civil service. Doubtless the dispensation of patronage outside the limits of the Directors' own family and local circles acquired new political overtones, as more men went into politics but the politics of the Director must even then have most frequently been Company rather than national politics, as Lucy Sutherland suggests. The period of dramatic ministerial intervention in elections to the Directorate was comparatively brief, and even then marginal. The rather wider area of recruitment, with one or two writerships for each of thirty or more counties may be the result of this change, but the only certain effect of the influence of national politics is to be seen in the distribution of the handful of Bengal writerships by Dundas and Pitt, and the notable growth of a Scottish element in the civil service.

It is in the military service of the Company 
that a new element is most clearly discernable - but here of course the service was itself a new one in effect. As might be expected it was the poorer, more disturbed areas of the British Isles which supplied many of the cadets - as they supplied the armies of the Crown. Scotland by 1800 was producing more cadets than the Home Counties, and Ireland not many fewer. From 1801, Ireland's position was to be recognised by the grant of a limited patronage to the Iord Iieutenant at Dublin.

The continuities outlined above meant that there was also considerable continuity in the class composition of the Company's services in India. Most members of the civil service remained middle class in origin, sons of merchants, businessmen and tradesmen, of lawyers, clergymen and other professional classes, of gentry and the minor nobility, with only occasional leruptions from members of the higher orders seeking to repair lost fortunes or honour, and even fewer from the lower orders. The need to produce testimony to proficiency in book-keeping and commercial arithmetic, and to put down considerable sureties for good behaviour must have served in any case to exclude the Rumbler classes from the civil service. In so far as their educational background is known, it is that of the public school, the grammar school or 
Scottish academy and of the counting-house.

The common middle class background of the writers, and of the younger sons who took cadetships made the Company's services in Bengal a fairly homogeneous body. The development of British official familes, whose members and collaterals went out generation after generation to India, often establishing links by marriage with other such families strengthened the closeness of British society in Bengal. This served to prevent any wide cleavage between the various branches of the services and maintained the links with the Company at home. We would suggest that it also served to create a British society in Bengal more closed than it might otherwise have been to Indian influences. It would also seem to have given some uniformity of tone to that society, hardliving, corrupt, a frontier society in the decades immediately after Plassey, more soberly middle class in its probity and efficiency towards the end of our period, by providing a common body of referants, as Cohn has described. The establishment of the College of Fort William and then of Haileybury merely reinforced this tendency. However the other side of the picture must not be lost sight of. The process of the development of British official families was consíderably retarded in 
our period by the prevalent practice of living with Indian women forced upon all but the most senior of the army officers and the civil servants. A new community was brought into existence with a new problem for the British society in Bengal and for the Company at home, creating a middle order between the Europeans and the Indians. The British in Bengal tried to tackle this problem by creating charitable institutions and societies while the Directors in England, aware of the British prestige in India and of their own interest at home, tried to cope with it by excluding the mixed generation from the services of the Company. The Anglp-Indian community unhappily remained as a bitter legacy of the period. The style of living of the British community in Bengal was essentially English. There were necessarily adaptations to the Indian climate, in the structural arrangement of the houses, though not in their style, in the use of tatties and pankahs, in the use of palanquins and doolies. Informal dress might also borrow from the Indian his shirt and loose pyjamas or trousers, the use of watex, externally, became more common, curries and arrack might join the menu. For a while the bookah too had a triumph, as did the nautch, and momentarily such exoticisms as animal fights. Nevertheless the predominant 
impression is that of Englishmen struggling to recreate a familiar background in a strange land.

Or rather, it might be truer to say, the picture is one of middle class Englishmen struggling to create a half-familiar background in India - that of the aristocratic English world to which they had aspired at home, and could in India create for themselves. In this sense the English in Bengal initially formed a community of nouveau riches, with their 'city of palaces' and their country retreats, retinues of servants, balls and masquerades, gambling clubs, horses and carriages, tiger hunts and pigsticking, lavish dining and drinking. The fact that in Bengal they were usurping the places of Mughals who had a similar tradition of ostentations living only made the transition easier and more natural.

Before the end of our period this hectic extravagance was becoming less acceptable. There were good practical reasons for this in the curtailment of the ppportunities for amassing sudden fortunes imposed with increasing success by Clive, Hastings and Cornwallis on civilians and military alike, and the introduction of regular promotion leading to comfortable but regulated salaries. At the same time the improved healthiness of Iife in India, and the greater expectation of living safely 
through to retirement, the opening of furlough arrangements, the coming of more English wives to Bengal, made service less of a gamble and more of a career, and so imposed restraint. Such curbs were powerfully reinforced by the change of climate within society in England. The Methodist and Evangelical movements in England, the reformism embodied in such persons as Hannah More, the emergence of a thrifty, hardworking body of industrialists was heralding the coming of the new middle class morality at home, and its influence was necessarily carried out with each new batch of recruits to the Bengal services.

These same changes made for an increasing withdrawal from Indian society. It is true that the later years saw the foundation of the Asiatic Society, and the growth of a scholarly interest in India's religions, history and culture, and in her geography, botany and zoology, but the strengthening of ties with England, when England was acquiring a new pride in her scientific and technological revolution, and was being subjected to a new wave of evangelical religion worked in a contrary direction. The greatness of India's past, the interest of her religious philosophy seemed less important than her political impotence in the present, and the certainties of English science and English religion. British society 
in Bengal, having passed through the heady adolescence of the post-Plassey years, and come to maturity, was in no mood to admit an equal. 
APPENDICES. 


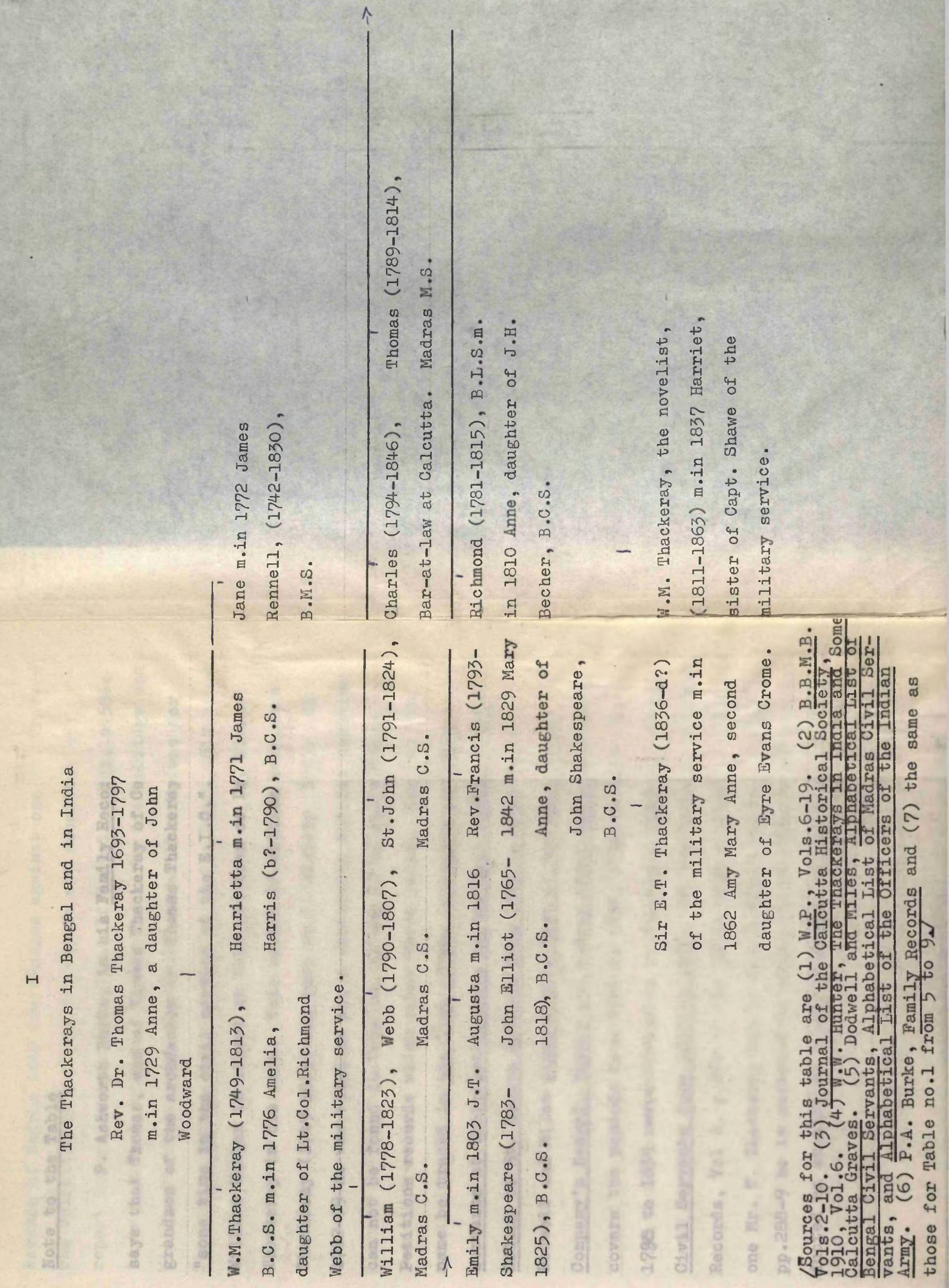


Note to the Table

P. Ashworth Burke, in his Family Records, p.594, says that Thomas, son of Thomas Thackeray of Cambridge and grandson of the archdeacon Dr. Thomas Thackeray was for "some time in the civil service of the E.I.C.". Sir William Hunter is silent on this grandson of Dr. Thomas Thackeray in his work. This nephew of William Makepeace Thackeray (1749-1813) was born on 11 January 1767. In 1782-89 he was eligible for a writership but his petition can not be found in Vols 10,11 and 12 of the Writers Petitions records which cover these years. Nor can his name be traced in the list of the Company's covenanted servants at their settlements in the East Indies \& the Island of St. Helena \& China from 1771 to 1799 or in Dodwell and Miles Alphabetical List of the East India Company's Bengal, Bombay and Madras Civil Servants which covers the periods from 1780 to 1838,1798 to 1839 and 1780 to 1839 respectively or in Prinsep's List of Madras Civil Servants from 1740 to 1858. In the Index to Personal Records, Vol 2, p.237 in the India office Iibrary, there is one Mr. T. Thackeray but in his Personal Record, Vol 18, pp.288-9 he is referred to simply as Mr. Thackeray who conducted an enquiry as a junior member of the Board of 
Revenue of Madras into the charges against one Mr. Travers, the Collector of Nellore and Ougole and submitted his report before January 10, 1810. If Dodwell and Miles are to be believed, that Mr. Thackeray can be identified with William Thackeray, the eldest son of William Makepeace Thackeray, who was a junior member of the Board of Revenue of Madras from September 10, 1806 to October 12, 1810 on which date he was appointed Chief Secretary to Government. (See Dodwell and Miles, op.cit., pp.278-9.) (The mistake has been pointed out to one of the staff of the India Office Iibrary and has been corrected.) Had Thomas Thackeray ever been in the civil service of the East India Company, his son-in-lav, Professor George Pryme would have certainly mentioned it in his autobiography but he simply described him as "an eminent consulting surgeon at Cambridge" when he married his daughter Miss Jane Townley Thackeray in 1813. (See Alicia Bayne, editor, Autobiographic Recollections of George Pryme, Cambridge, 1870, p.103.) In any case, Burke's statement seems to be vague and uncertain and therefore Thomas Thackeray's name has been omitted from the Table. 


\section{II}

Ninety-five

I am a younger son of Mars, and spend my time in carving A thousand different ways and means to keep myself from starving;

For how with servants' wages, Sirs, and clothes can I contrive To rent a house, and feed myself on scanty ninety-five.

Six mornings out of seven, I lie in bed to save The only coat my pride can boast, the service ever gave; And as for eating twice a day, as hereto-fore, I strive To measure out my frugal meal by scanty ninety-five.

The sun sunk down in Thetis' lap, I quit my crazy cot, And straight prepare my bullock's heart, a liver for the pot :

For Khitmudgar or Cook I've not, to keep my fire alive, But puff and blow, and blow and puff, on scanty ninety-five. 
My evening dinner gormandiz'd, I buckle on my shoes, And stroll among my brother subs in quest of better news; But what, alas! can they expect from orders to derive, Which scarce can give them any hopes of keeping ninety-five.

\section{5}

The chit chat hour spent in grief, I trudge it home again, And try by smoking half the night, to smoke away my pain; But all my hopes are fruitless, and I must still contrive To do the best a hero can on scanty ninety-five.

\section{6}

Alack! that e'er I left my friends to seek my fortune here, And gave my solid pudding up, for such uncertain fare; OH: had I chose the better way, and staid at home to thrive, I had not known what 'tis to live on scanty ninety-five.

This balad was published in the Poet's Corner of the Calcutta Gazette, 8 March 1787. See Seton-Karr, op.cit., Vol 1, pp.197-8. 


\section{III}

Excerpts from Wills showing the testators' provision for their Indian mistresses and natural children.

1. "I give devise and bequeath to Maria a Woman Löf Portuguse origin7 I know and have cohabitted with for seven years and upwards as a Token of my Affection and reguard to her for her Fidelity and Care of me the Sum of Two Thousand Current Rupees and request that my Executors here in after named do as soon as Possible put out the Said Sum at Interest in the most Secure and advantegious Way the Interest arising thereon to be paid the said Maria monthly for her maintenance during the Term of her natural Life . . I also leave and bequeath to the said Maria (till my Executors can be able to collect in my affairs so as to enable their putting out the said sum at Interest) the sum of Five hundred Rupees to be paid her immediately after my decease for her maintenance and further leave and bequeath her all her wearing apparel . . of what Kind or nature so ever . . .. I leave bequeath and Devise unto Mary and Edward my Natural Children by the aforesaid Maria, to be shared equally between them, 
the rest and residue of my Estate of what Kind so ever or where so ever in India."

Will of Edward Ridge, Registrar of the Mayor's Court, Calcutta. Dated 19 November 1759. Filed 2 May 1760. See B.W., 1751-60, Range 154, Vol.50, p.8.

2. "I Bequeath unto my two Children by Morad bux one of which is now in England and the other under her care and protection at Patna at this present Juncture six hundred pounds sterl ${ }^{g}$ each and If either of them should die before they come to age I desire four hundred of the deceaseds share may be added to the Survivors and the remaining two hundred to be given to my Brother Davids Eldest Son James or If both of them dies before they come of age I then desire that six hunared of it may be divided equally among my Brother Davids Children and the other Six hundred among my Sisters and I request that my Brother David Skinner of Bordeaux and Ensign William Anne Skinner my cousing German in Bengal will act as Guardians and protectors of to the said Children untill they come to proper age and upon my acct. take care they are setled in the World properly and conformable to their circumstances and untill they are of age that their Legacys may be 
secured at Interest which Income is to Maintain them.

To their Mother Morad bux I bequeath the amount of my Furniture (by my Friend Dr. Peter Clugh) sold at outcry at Patna and which I have directed the said Dr. Clugh to place it at Interest on Bond in her name and upon her acct and I desire the sum shall be made up to two thousand Patna Sonat Rupees for her use \& to be paid her immediately on my decease and I further request that my friend Dr. Clugh will lay it out as he thinks best for her advantages."

Will of Capt. James Skinner, in the Service of the Company. Dated $18 \mathrm{July}$ 1773. Filed $18 \mathrm{March}$ 1774. See B.W. 1771-74, Range 154, Vol.55, pp.10-1.

3. "In the Name of God Amen I Benjamin William Warren Iieutenant in the service of the Honble East India Company \& on the Bengal Establishment do hereby make this my last will \& Testament in form \& manner following. First I give and bequeath to my natural Daughter, tho' not christen'd yet generally called by me Charlottee Warren, begot upon the Body of my late House Keeper Doordana the sum of Siccon Rupees 10,000 (Ten thousand) to be by my Executors placed at Interest according to the best of their judgment to 
the greatest advantage \& security so as to answer the purposes of clothing her, sending her to England \& educating her in a genteel and suitable manner \& so as to avoid touching my part of the principal, which is to be her marriage portion, \& if at the Age of twenty three years she should not have entered into the marriage state the principal is then to be put into her free \& uncontroled possession but prior to that age (excepting only in case of marriage) she is to receive but the Interest accruing from the afore said sum."

Will of It. Benjamin William Warren. Dated 30 March 1787. Filed 20 May 1787. B.W. 1787-1790. Will No.14. No volume number. No pagination. 


\section{IV}

A Selection of Inventories at the Mayor's Court and Supreme Court, Calcutta, throwing light upon British Iife in Bengal in the later Eighteenth Century.

I. Selections from the account sale of Lieutenant Tuite, I May 1758.

A Goiget; A Hooker glass; Two silver Spoons; A Remnant of Camblet; A Pair of Garter Buckles; Three odd Volumes; A small Weather Glass; 4 China Cups \& Saucers; A Plate \& Tumbler; A Camp Trunk; A Carpet; Bedding \& Pillows; A Couch and pair of Boots; A Black Sattin Coat and Point D Spaigne Hat; A Gold Laced Hat; A Regimental Coat and Waste Coat; A Remnant of blue Velvet; An old Scarlet Coat and Waste Coat; A Pair Muslin Musketo Curtains and Couch; A Remnant of Scarlet cloth; A Remnant Yellow silk; A set of silver ... Buttons; 13 Linen Breeches; 12 silk Handkerchiefs; A Pr. black silk for Breeches; 7 Pair silk Breeches; 7 Neck Cloths; 16 Old Shirts; 3 Cow Tails with a silver Handle; 9 Waste Coats; A Chest; An Escritoir \& 2 Chairs; An Imbroidered Waste Coat; A pair silver Buckles; A Gold wire Breast Buckle.

(Source: Bengal Inventories at the Mayor's Court, Range 154, Vol.61, p.69.) 
II. Selections from the account sale of John Mackintosh, 14 December 1770.

1 China Turin; 8 China Dishes; 5 Dozen China Shallow Plates; 6 China small Pickle plates; 4 China salt cellars; 3 Dozen \& 6 Wine Glasses; 3 Tumblers; 2 Glass Muggs; 2 Copper Kettles; 2 Copper Saucepans; 1 Copper Stewpan; 4 Iron pans; 6 Chairs; 2 Tables; 2 Teapois; 2 Beds; 3 Pillows; $1 \mathrm{Pr}$. Curtains; 1 Large China Chest; 1 Large Looking Glass; 2 Trunks; 1 Black Wood Coutch; 6 Stocks; 6 Shirts; 6 Banyan Shirts; 15 New Handkerchiefs; 6 Plain Shirts; $12 \mathrm{Pr}$. silk stockings; 12 Shirts; 6 Waist coats; 6 Stocks; 7 Waist coats; 8 Long Drawers; 4 Shirts; 1 towel; 1 Hooka; Some old Shoes; 1 Glass Lanthern; I Pr. Glass Shades; Smolet's History of England, 15 Vols; Swift's Works in 21 Vols; Shakespeare's Works, 9 Vols; Don Quixote, 4 Vols; Milton's Works, 2 Vols; Memoirs of Pompadore, 2 Vols; 6 silver Table Spoons; 1 silver supper spoon; 1 silver Candelstick; 2 Banyan Gowns; 6 pr. of Breeches; 2 table cloths; 1 Shawl; I Militia coat; I Green coat Gold Laced; I Green Waist coat Gold Laced; 1 silver Embroidered cloth coat; 1 silver Embroidered white satin Waist coat; 2 Blue silk coats; 1 Waist coat; 7 Pr. new satin Breeches; 5 Pr. Nankeen; 5 Hats; 1 Backgamon Table; 4 small Europe Pictures; 2 Pr. of Gilt Shoe 
\& Knee Buckles; 1 pr. of Gilt Sleeve Buttons; I silver Watch; 4 Dozen Porter; 4 Bottles Dutch Claret; 2 Malay slave-girls; 4 Empty Gin cases; The History of Tom Jones.

(Source: Bengal Inventories at the Mayor's Court, Range 154, Vol.69, p.139.)

III. Selections from the account sale of Captain Thomas Baillie, 10 February 1780.

12 pr. Shirts; 12 Waist coats; $12 \mathrm{pr}$. of Breeches; $12 \mathrm{pr}$. of Bolton stockings and 12 stocks; 12 Shirts, some ruffled some plain; $12 \mathrm{p}$. of silk Stockings; Banian shirts; 3 Banian Gowns; 4 Small Tables; A sett of Dyning Tables; 3 Chairs and 2 Teapoys; 1 Embroidered Coat \& Waist Coat \& 1 pr. of Cloth Breeches; 1 plain coat and 2 Breeches; I Laced Hatt \& I Velvet Cap; I Sword; I pair of Pistolls; 16 old Books; 1 Bible; 1 pr. of Boots; 7 pr. of Shoes; 1 whip; 2 Silver Sugar Dishes; 1 Silver Saucepan; 1 Silver Soup plate; I pr. of Candle Stick; I Gold Watch; I pr. of Gold Buckles; 1 sett of silver Buckles; 1 Case containing 10 Bottles of Lime Shrub; 2 Chests containing 9 Dozen and 3 Bottles of Porter; 1 case containing 3 Bottles of Gin; 1 Chest containing 6 Bottles of Liquor of Different sorts; 1 cask of Vinigar; 1 Cott \& Curtains; 
1 Couch, 1 Bed, 2 Pillows; Dried Meat; 1 Tea Kettle;

1 White horse with Saddle and Briddle; A Bangellow;

2 Carriage Hackris with 4 Bullocks; 1 small old Budgerow;

2 Dogs; Some Poultry; 2 Carpets; 1 China Chillimachi.

(Source: Bengal Inventories at the Supreme Court, Range I, Vol. 1, p.7.)

IV. Selections from the inventory of Ellenor Frost, 6 May 1789.

2 Couches; 10 old chairs; 1 Cott with Quilt \& Pillows;

I small table \& I Stool; A Chair Palanquin; 1 Hooka Bottom; A Hindostan Chillemchee \& Ewer; 4 Brass Candlesticks; 4 Brass Plates; I Copper Pigdanee; I silk Petticoat \& Jacket /with Lace/; 2 Silk Petticoats; 5 Chintz Petticoats; 2 white Petticoats \& 11 Jackets; 2 pr. of Stockings; I Bowl; I Dish; I Mug; I Decanter;

1 Tumbler; A white Shawl /Large Flowered/; I Shawl Handkerchief; 1 Pair Gold Bracelets; 1 Pair Gold necklace; 1 Pair Gold Earrings with Pearls; 1 Golconde Pearl;

1 Pr. Gold Bracelets of 5 strings; 28 large Pearls;

1 Gold Necklace of 5 strings; $1 \mathrm{Pr}$. Gold Sardellas with Pearls \& Malabar Stone; 1Diamond Ring; 1 Malabar stone Ring; I Ruby Ring; 2 Pair Gold sleeve Buttons; 1 Oval 
sleeve Button; I pair Shoe Buckles; 2 Silver Table Spoons; 2 Tea spoons; 1 Chest; 2 Looking Glass.

(Source: Bengal Inventories, at the Supreme Court, Range 1, Vol.2, pp.284-6.)

V. Selections from the inventory of S.M. Taylor, 18 March 1799.

Silver: Table spoon - 24; Tea spoon - 8; Milk spoon - 2; Soop spoon - 2; Butter Knive - 1; Salt spoon - 6; Small forks - 24; Large forks - 23; Sauspan - 2; Salt Saler - 2; Hot Water pott - 2; Butter pott - 1; Coffy pott - 1; China: Dishes - 24; Dish to cover fish - 1; Plates - 16; Soup Plates - 16; Green Dishes - 3; Sweet Meat Plate - 20; Coffy saucer \& cups - 32; Tea saucer \& cups - 19; Cutlery: Table Knives - 37; Table forks - 38; Small knives - 21; Small forks - 26; Glass: Butter pott - I; Plates - 15; Salt Saler - 7; Madeira Glass - 12; Claret Glass - 9; Frying Pan - 2; Roasting spit - 2; Copper Spice Box - 1; Hanging Lantharn - 2; Wall Shades - 16; Candlesticks - 2; Dining Table - 2; Round Table - 2; Card Table - 4; Chairs - 36; Teapoy - 10; Picture - 4; Picture with frame \& Glass - 25; 1 Trunk with papers - 1; Writing Box - 1; Hanging fan - 2; Cott - 1; Couch with 
Bedding - 1; Powder Box - 1; 1 Basket containing Music books \& 1 Iooking Glass; Chair Palanquin \& Fly Palanquin; Banyan Shirts - 19; Short Drawyers - 9; Shirts - 62; Waist coat - 16; Shawl Shirts \& Drawyers - 2; Towels - 21; Nankin Breeches - 26; Iinen Breeches - 4; Handkerchiefs - 17; Silk stockings - 69; A Very Elegant Europe built Charriot \& 5 Horses with Complete Harness.

(Source: Bengal Inventories, at the Supreme Court, Range 1, Vol. 21, Part 1, No pagination.)

It should be noted that in the case of account sales the names of the buyers and the prices obtained have been omitted. Spelling mistakes and capital letters have been left unaltered.

See also Appendix A in T.G.P. Spear's The Nabobs, p.181 et seq. 


\section{V}

Monthly wages of household servants as fixed in 1759 , 1785-7 and 1801, by the Quorum of Zemindars.

Bearers ${ }^{1}$, each Arcot Rs.2 Sicca Rs.- Current Rs.15-20

Chubdar ${ }^{2}$

"

Coachman

$5 n$

5

$15-30$

Consumer(Khansaman) $)^{3}$ "

Cook

$"$

" First Mate

"

Dry Nurse

"

5 "

10

5 "

11

5 "

6

5

$n$

$10-16$

3 "

4

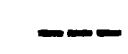

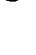

1

(2)

n

$10-25$

$10-20$
" 12-16
Besides cloths and pawn

Grass Cutter

"

Harry Woman ${ }^{4}$ to a

Family

" to a Single Person ".

House $\mathrm{Mall} \mathrm{y}^{5}$

"

Jammadar 6

n

Kedmut dar

(Khidmutgar)?

"

$3 \quad 1$

3

$"$

$2-4$

5

Kurtchburdar 8

n

Peons 9 , each

2

2

"

3

12

II

$3-4$

2 "

3 11

4

$6-10$

Second Female Servant

$"$

"

Shaving Barber

$"$

3

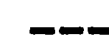

$51 \%$

$6-12$

4

$5 \%$

$31 / 2-4$

n

4-6

$1 / 2 " 1 / 2$

"

.2-4 
Syce $^{10}$

Arcot Rs.2 Sicca Rs.4/2 Current Rs. 6-4

Washerman to a

Family

"

$3 \quad n$

10

$6-8$

" to a

Single Gentleman

Wet Nurse

\begin{tabular}{|c|c|c|c|c|c|}
\hline$"$ & $1 / 1 / 2$ & $"$ & 4 & $1 "$ & $5-6$ \\
\hline " & 4 & -- & & $\begin{array}{l}\text { " } \\
\text { Besides } \\
\text { and pawn }\end{array}$ & $\begin{array}{l}12-1 \\
\text { cloth }\end{array}$ \\
\hline
\end{tabular}

1 Arcot $\mathrm{Rs}=1$ Sicca $\mathrm{Rs}=2 \mathrm{~s} .3 \mathrm{~d}$.

1 Current $\mathrm{Rs}_{\mathrm{s}}=2 \mathrm{~s}$.

LSources: (1) Bengal Consultations, 21 May 1759 in Rev. J. Long, Selections from the Unpublished Records of Govt... of Bengal, 1747-67, pp.181-4; (2) W.S. Seton-Karr, Selections from the Calcutta Gazettes, Vol.1, pp.94-6; (3) Rev. J. Iong, Calcutta in the Olden Time in Smith's Selections from the Calcutta Review, Vol.8.7

1. Valet. 2.Clubman, mace bearer. 3.Store-keeper or cook. 4. A female servant of the lowest class, or female sweeper. 5.Gardener. 6.Chief of the servants' staff. 7.Attendant. 8.Purveyor. 9.Messengers or footmen. 10.Groom. See Yule and Burnell's Hobson and Jobson and H.H. Wilson's A Glossary of Judicial and Revenue Terms and of useful words.. of the Govermment of India and pp.58-67 in Henry Grant and Edward Colebrooke's The Anglo-Hindoostanee Handbook. 
The daily Iife of an Englishman in Bengal in the 1770's.

"About the hour of seven in the morning, his durvan (porter or doorkeeper) opens the gate and the viranda (gallery) is free to his circars ${ }^{1}$, peons (footmen) harcarrahs (messengers or spies) chubdars (a kind of constable) huccabadars and consumas (or steward and butler), writers and solicitors. The head-bearer and jemmadar enter the hall, and his bed-room at eight o'clock. A lady quits his side, and is conducted by a private staircase, either to her own apartment, or out of the yard. The moment the master throws his legs out of bed, the whole posse in waiting rush into his room, each making three salams, by bending the body and head very low, and touching the forehead with the inside of the fingers, and the floor with the back part. He condescends, perhaps, to nod or cast an eye towards the solicitors of his favour and protection. In about half an hour after undoing and taking off his long drawers, a clean shirt, breeches, stockings and slippers are put upon his body, thighs, legs and feet, without any

1. Sircars or Sarkars are domestic servants who act as house-stewardes, keep the accounts of household expenditure and make miscellaneous purchases for the family. Yule and Burnell, op.cit., pp.840-1. 
greater exertion on his own part than if he was a statue. The barber enters, shaves him, cuts his nails, and cleans his ears. The chillumjee ${ }^{l}$ and ewer are brought by $a$ servant whose duty it is, who pours water upon his hands and face, and presents a towel. The superior then walks in state to his breakfasting parlour in his waistcoat; is seated; the consumah makes and pours out his tea, and presents him with a plate of bread or toast. The hairdresser comes behind, and begins his operation, while the houccaburdar softly slips the upper end of the snake or tube of the hucca into his hand; while the hairdresser is doing his duty, the gentleman is eating, sipping and smoking by turns. By and by his banian presents himself with humble salams, and advances somewhat more forward than the other attendants. If any of the solicitors are of eminence, they are honoured with chairs. These ceremonies are continued perhaps till ten o'clock, when, attended by his cavalcade, he is conducted to his palanquin, and preceded by eight to twelve chubdars, harcarrahs, and peons, with the insignia of their professions, and their livery distinguished by the colour of their turbans and cumberbands (a long muslin belt wrapt around the waist)

1. A basin of brass or tinned copper for washing hands. See Yule and Burnell, op.cit., pp.195-6. 
they move off at a quick amble; the set of bearers, consisting of eight generally, relieve each other with alertness, and without incommoding the master. If he has visits to make, his peons lead and direct the bearers; and if business renders his presence only necessary, he shows himself, and pursues his other engagements until two 'clock, when he and his company sit down, perfectly at ease in point of dress and address, to a good dinner, each attended by his own servant. And the moment the glasses are introduced regardless of the company of ladies, the houcca leaders enter, each with a houcca and presents the tube to his master, watching behind and blowing the fire the whole time. As it is expected that they shall return to supper, at four o'clock they begin to withdraw without ceremony, and step into their palanquins; so that in a few minutes, the master is left to go into his bedroom, when he is instantly undressed to his shirt, and his long drawers put on; and he lies down on his bed, where he sleeps till about seven or eight o'clock then the former ceremony is repeated, and clean linen of every kind, as in the morning, is administered; his huccabadar presents the tube to his hand, he is placed at the tea table, and his hairdresser performs his duty as before. After tea, he puts on a handsome coat, and pays visits of ceremony to 
the ladies; returns a little before ten o'clock; supper being served at ten. The company keep together till between twelve and one in the morning, preserving great sobriety and decency; and when they depart, our hero is conducted to his bed room, where he finds a female companion to amuse him until the hour of seven or eight next morning. With no greater exertions than these, do the Company's servants amass the most splendid fortunes."

LSource: James Mackintosh, Travels in Europe, Asia and Africa, 1771-81, Vol.2, Letter 55 (Calcutta, 23 December 1779), p.214 et seg.7 


\section{Note:}

It appears that Mackintosh's description refers to the well-to-do senior but bachelor officials of the Company in Bengal and was a pattern of life to be followed by unmarried junior servants of the Company and other nonofficials. Mackintosh's Eravels drew forth strong protest from another contemporary, Capt. Joseph Price, in his pamphlet on Some Observations and Remarks on a late Publication entitled Travels in Europe, Asia and Africa, published from Iondon in 1782. Price characterised Mackintosh's description of English life in Bengal in the seventies as "a strong, but highly caricatured likeness of the manners of the Europeans in general who serve in Asia" and stresses that "the pomp and state he reports them to live in, comes but to the share of those few, who live long enough to rise by slow degrees, and after many years service, to the highest offices in the state" (p.76). After trying to vindicate the life of the junior servants of the Company against the charge of luxury made by Mackintosh, he finally surrenders, "Hear me, you English mothers and daughters; grudge not to your sons and brothers the . . indulgences . . for leaving of your parental and fraternal embraces in the blossom of life, to 
end their days in foreign land, and never see you more." $(\mathrm{p} \cdot 79)$

Dr. Spear, who may not have seen Price's pamphlet, comes to the same conclusion regarding the authenticity of Mackintosh's description from a study of other contemporary sources such as Hickey, Williamson and D'Oyly. "The picture is correct in the main", he writes in the footnote to pages 53-5, "but allowance must be made for exaggerations in order to secure sensational and picturesque effect. It must not be imagined that all Anglo-Indians adopted this mode of life; many of the highest like Hastings, Cornwallis, Macartney and Shore were hard workers and lived simple lives." 


\section{VII}

The daily life of a lady.

"A lady . . . is called some time before sunrise, and her ayah brings her every article of dress, completely clean, fresh from the dhoby. She is enveloped, over her morning wrapper, in a splendid Cashmere shawl, and she is then carried out to take the air, either in a carriage or open palanquin. Soon after sunrise she returns, and having taken some coffee, she goes to bed and if she can, sleeps soundly for an hour or two. She is roused before the family breakfast-hour, in sufficient time to go through a somewhat elaborate toilet; not that she uses the smallest exertion herself, but goes through every process of bathing, hair-dressing, and so on under the hands of one or two black women.

The lady's toilet being finished, she issues from her apartment into the hall, where a breakfast is set out in the most elegant style, and where many gentlemen soon drop in. The meal is a public one, and continues some time, during which much polite conversation is carried on; the company then disperses, and she withdraws to some elegant room, where she reads a little, does a little 
fancy work, receives or writes a few notes, or receives some lady visitor. She knows a good deal of the gossip of the Europeans, but little of the ways and habits of the natives.

A little renewal or change of dress is made again before tiffin, at which time the table is set out with the same display as at breakfast; and the vacant seats are again occupied by guests. This is the best meal in the day, and much wine and pale ale is drunk. The party does not often sit after tiffin, and our lady withdraws to her own suite, takes off her outer dress and ornaments, and lies down, remaining asleep or perhaps reading till the heat of the day is past, and the sun low. Then follows a still more elaborate process of dressing, with an entire change of every article of wearing apparel, and the lady goes forth to take the air in her carriage, generally on the course, where she meets all the great people of Calcutta, and has the opportunity of smiling on her female friends and receiving the bows and compliments of the gentlemen. On her return she adds a few jewels to her dress, and sits down to dinner with her husband, after which she most often goes out to a ball or assembly, for which a last and still more magnificent toilet must be made." 


\section{Note:}

This account of a lady's life at Calcutta is given by Mrs. Sherwood in her journal, later edited by F.J. Harvey Darton as The Life and Times of Mrs. Sherwood (1775-1851), (pp.358-9). She went to India with her husband, a Captain in the service of the King, in 1805. She collects this account from Mrs. Shoolbred who had been living in Calcutta for some years, and precedes it with a comment "And II7 have never since ceased to marvel how such an existence can be endured for more than a week by a delicate female in such a climate, though many carry it on for years" (p.358). 


$$
2
$$

BIBLIOGRAPHY 


\section{Primary Authorities}

\section{Manuscript Sources}

A. Records at the India Office Iibrary; London

Bengal Baptisms, Marriages and Burials, vols. 2, 4, $5,6,10$.

Bengal Civil Servants, vols. 1, 2.

Bengal Inventories, Range 154, vols. 61 and 69; Range 1, vols. 1, 4, 11, 14, 21 (Part 1).

Bengal Letters Received, vols. 34, 35.

Bengal Wills, Range 154, vols. 50 and 55, and unnumbered volumes for 1787-90, 1798-9.

Cadet Papers, vol. 5.

Cadet Register, vols. 1, 3.

(Cadet Papers and Cadet Register have recently been recatalogued in A Guide to Military Records. Formerly they were in The Iist of General Records.)

Court Books, vols. 79, 93, 100, 100A, 103A, 116A.

Despatches to Bengal, vols. 1, 2, 4, 14, 32.

European Inhabitants in Bengal, vol. 1.

Europeans in India, vols. 2, 4.

Factory Records: Letters to India, vol. 8.

Home Miscellaneous Series, vols. $67,79,85,398,817$.

Personal Records, vols. 1, 3, 7, 10, 12, 13, 14, 18.

Secret Court Minutes, vol. 7.

Writers' Petitions, vols. 1 to 17, 19, 25. 
B. Private Papers at the Baptist Missionary Society, London.

Journal of William Carey, $1793-5$ and his Various Correspondence, 1795-1831. Box No. iN/13.

C. Private Papers at the British Museum, London. Warren Hastings' Papers. Add Mss. Nos. 29163, 29175, 29176, 29178.

D. Private Papers at The India Office Iibrary, Iondon. Colonel Champion Papers, Home Miscellaneous Series, V01. 198 .

Charles Grant Papers, Mss. Eur. E. 93, Mss. F. $18 / 1$

David Scott Papers, Home Miscellaneous Series, vols. 728 to $731 \mathrm{~A}$.

Major James Rennell Papers, Home Miscellaneous Serles, vol. 765 .

Orome Papers, vol. 15, 27, 164(A).

Francis Papers, Mss. Eur. E13 K47, Mss. Eur. E15 K49, Mss. Eur. El7 K52, Mss. Eur. E18 K53, Mss. Eur. E19 K54, Mss. Eur. E23 K66, Mss. Eur. E25 K68.

Fowke Papers, Mss. Eur. E3 K20, Mss. Eur. E4 K24, Mss. Eur. E5 K26, Mss. Eur. E6B K27, Mss. Eur. E7 K28, Mss. Eur. E8 K29, Mss. Eur. E9 K30, Mss. Eur. D10 K23, Mss. Eur. DII K25, Mss. Eur. F. K22. 
II Printed Sources

A. Official Publications

Iist of the Company's Civil Servants at their settlements in the East Indies, the Island of St. Helena \& China, 1771-1799

Buchanan, C., editor,

Cooper, J., editor,

Crawford, D.G., editor,

Dodwell, E., and Miles, J.C., editors,

,

Hill, S.C., editor,
The College of Fort William in Bengal. London, 1805.

Census Report of India, 1911. Calcutta, 1913.

Census Report of India, 1931. Delhi, 1933.

Original Papers Relative to the Establishment of a Society in Bengal. Iondon, 1784.

Roll of the Indian Medical Service, 1615-1930. London, 1930.

Alphabetical Iist of the Hon. East India Company's Bengal Civil Servants, 1780-1838. London, 1839.

Alphabetical list of the Hon. East India Company's Bombay Civil Servants, 1798-1839. Irondon,

Alphabetical Iist of the Hon. East India Company's Madras Civil Servants, 1780-1839. London, 1839.

Alphabetical list of the Officers of Ehe Indian Army. London, 1838.

Bengal in 1756-7, 3 vols. Iondon, 1905. 
Hill, S.C., editor,
Iist of Europeans and others in the English Factories in Bengal at the time of the siege of calcutta in the year 1756. Calcutta, 1902.

Hodson, Major V.C.P., List of the Officers of the Bengal editor, Army, 1758-1834, 4 vols. Iondon,

Holmes \& Co., editor,

Long, Rev. J.,

Love, H.D., editor,
The Bengal Obituary. Iondon, 1851.

Selections from the Unpublished Records of Government relating mainly to the Social condition of Bengal. Calcutta, 1869.

Vestiges of old Madras, 1640-1800, 3 vols. London, 1913.

Parliamentary History (after 1803 Enown as Parliamentary Debates), vols. $17,24,30$.

Parliamentary Papers, House of Commons, 1809, vol. 2; 1830, vol. 5; 1831-2, vol. 9; 1878, vol. 62, Part $2(17,11)$.

Parliamentary Papers, House of Lords. 1830, vol. 6 ; 1831-2, vol. 9.
Philips, C.H. and D., Alphabetical List of the Directors editors,

Philips, C.H., editor,

Prinsep, C.C., editor, of the East India Company, 17581858. Journal of the Royal Asiatic Society of Great Britain and Ireland. Iondon, 1941.

The Correspondence of David Scott, 2 vols. London, 1951.

Record of Services of the Hon. East India Company's Servants in the Madras Estabisshment, 1741-1858. London, 1885. 
$\begin{array}{ll}\text { Ross, C., } & \text { Correspondence of Charles, Pirst } \\ \text { editor, } & \frac{\text { Marquis Cornwallis, } 3 \text { vols. London, }}{1859 \cdot}\end{array}$

Sainsbury, E.B., A Calendar of the Court Minutes of the liast India Company, 1635-79, II vols. Oxford, 1935 .

Salatore, B.A., Fort William - India House Correspondence, 1782-5, Vol. 9. Delhi 1959.

Sinha, N.K.,

"

n

"Vol. 5.

editor Delhi,1949.

Wheeler, J.F., Early Records of British India. London,1878.

Wilson, C.R., editor,

Early Annals of the English in Bengal, 3 vols. Calcutta, 1895-1917.

List of Inscriptions on Tombs or Monuments in Bengal. Calcutta, 1896.

Old Fort William in Bengal, 2 vols. London, 1906. 
B. Contemporary Diaries, Letters, Memoirs, Pamphlets and Polemical Works.

Asiaticus

Genuine Memoirs of Asiaticus (ed. by

(P.D. Stanhope),

W.K. Firminger). Calcutta, 1909.

Babar, the Emperor of India,

The Baburnama (tr. from the original Turki by A.S. Beveridge) 2 vols. London, 1922.

Blackiston, Major J. Twelve Years' Military Adventures in Hindustan, 1802-14. London, 1829.

Bolts, William,

Considerations on Indian Affairs London, 1772.

D'Oyly, Charles, Tom Raw, the Griffin. Iondon, 1828.

Elers, Capt. G., Memoirs of George Elers, 1777-1842 (ed. by Lord Monson and George Leveson Gower from the original mss.). Iondon, 1903.

Fay, Mrs. Eliza,

Original Ietters from India, 1779-1815 (ed. by E.W. Forster). Iondon, 1925.

Firminger, W.K., editor,

The Ietters of Richard Barwell in the Journal of the Calcutta Historical society, vols. 8-18.

Forbes, J.,

Oriental Memoirs 4 vols. Iondon, 1813.

GoIdborne, Sophia, Hartly House, 3 vols. Iondon, 1789.

Graham, Maria,

Journal of a Residence in India, 1809-11. Edinburgh, 1812.

Grand, George Francis,

The Narrative of the Iife of a Gentleman long Resident in India (ed. by W.K. Firminger). Calculta, 1910.

Grant, Charles,

Observations on the State of Society in India in 1792. London, 1797. 
Grant, Robert,

Grier, S.C. (Hilda Gregg), editor, Hadley, George,

Hearsey, Sir J.B.,

Hickey, William,

Jahangir, the

Emperor of India,

Johnson, James,

Kindersley, Mrs.,

Iindsay, Robert,

Munro, Capt. Innes,

Nathan, Mirza,
The Expediency Maintained of continuing the system by which the Trade and Government of India are now Regulated. Iondon, 1813.

The Ietters of Warren Hastings to his Wife. Edinburgh, 1905.

A Compendious Grammar of the Current Corrupt Dialect of the Jargon of Hindustan (commonly called Moors). Iondon, 1809

Autobiography of Sir J.B. Hearseay in The Hearseys (ed. by Col. H. Pearre). London, 1905.

Memoirs of William Hickey, 1749-1809, (edited by Alfred Spencer), 4 vols. London, 1925.

The Tuzuki-Jahangir, tr. by A. Rogers and ed. by $\mathrm{H}$. Beveridge, 2 vols. Iondon, 1909, 1914.

The Influence of Tropical Climate on European Constitutions. Iondon, 1813.

Letters from the Island of Teneriffe, Brazil, the Cape of Good Hope, and the East Indies. Iondon, 1777.

Anecdotes of an Indian Iife in Iives of the Iindsays (edited by Iord Lindsay), 3 vols. London, 1840.

A Narrative of the Military operations on the Coromandel coast against the combined forces of the French, Dutch and Hyder AlIy Cawn, 1780-84. Iondon, 1789.

Baharistan-i-Ghaybi (tr. by M.I. Borah), 2 vols. Ganhati, 1936. 
Nugent, Lady Maria, A Journal from the year 1811 till the year 1815 including a Voyage to and Residence in India, 2 vols. 1839.

Officer, an, Sketches of India. Iondon, 1825 [1821].

Orme, Robert,

A History of the Military Transactions of the British Nation in Indostan from the year 1745, 2 vols. London, 1803.

Pester, Capt. John, War and Sport in India, 1802-6 (edited by J.A. Devenish). London, 1913.

Price, Capt. Joseph, The Saddle Put on the Right Horse; or An Enquiry into the reasons why certain persons have been denominated Nabobs. London, 1783. Published anonymously.

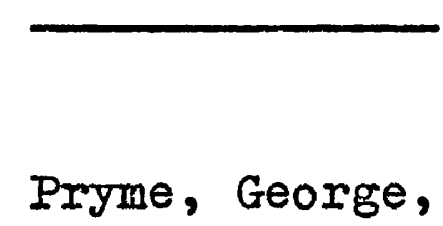

Sherwood, Capt. and Mrs.,

Shore, Sir J.,

Tennant, Rev. William,

Wallace, It. R.J.,

Williamson, Capt. Thomas,
Some observations and Remarks on a late Publication entitled lravels in Europe, Asia and Africa. London, 1782.

Autobiographical Recollections of George Pryme, (edited by Miss Jane Townley). Cambridge, 1870 .

The Life and Times of Mrs. Sherwood, 1775-1851 (edited by F.J. Harvey Darton). Iondon, 1910.

Memoirs of the life, Writings and Correspondence of Sir William Jones. London, 1804.

Indian Recreations, 3 vols. London, 1804.

Fifteen Years in India, 1802-16. London, 1823.

The East India Vade Mecum, 2 vols. London, 1810 . 
C. Contemporary Travellers' Accounts.

Bernier, François, Voyages de François Bernier, 2 tom. Amsterdam, 1699.

Charpentier Coosig- Voyage au au [zic] Bengale ... fait ny de Palma (Joseph en 1789, 2 tom. Paris, 1799.

François),

Grandpré, I. De.,

A Voyage in the Indian Ocean and to Bengal, 1789-90, 2 vols. London, 1803.

Grose, J.H.,

A Voyage to the East Indies, 1750-64, c vols. London, 1766 [1757].

Hamilton, Capt. A., A New Account of the East Indies, 2 vols. Edinburgh, 1727 .

Heber, Rev. R.,

Narrative of a Journey through the Upper Provinces of India, 2 vols. London, 1828.

Hodges, W.,

Travels in India during the years 1780-2. Iondon, 1793.

Ives, Capt. E.,

A Voyage to India in 1754. London, 1773

Jacquement, V.,

Voyage dans 1'Inde, 6 tom. Paris, 1835-44.

Johnson, J.,

The Oriental Voyager, London, 1807.

Khan, Mirza A.T.,

The Travels of Mirza Abu Taleb Khan

in Asia, Africa and Europe during the

years 1299-1803, (tr. by Charles

Stewart from Persian into English),

3 vols. Iondon, 1810.

Mackintosh, J., Travels in Europe Asia and Africa,

1771-81, 2 vols. London, 1782 .

Niebuhr, C.,

Voyages en Arabie \& en d'autres Pays Circonvoisins, (tr. by H.I. Mourier from Dutch into French), 2 tom. Amsterdam, 1776-80. 
ovington, F.,

Stavorinus, J.S.,

Twining, T.,

Valentia,

Viscount G.,
A Voyage to Surat in the Year 1689. Iondon, 1696.

Voyages to the East Indies, 1768-71

(tr. by S.H. Wilcocke from Dutch into English), 3 vols. London, 1798.

Travels in India : A Hundred Years Ago. London, 1893.

Voyages and Travels to India, Ceylon, the Red sea, Abyssinia, and Egypt in the Years 1802-6, 3 vols. Iondon, I811 [1809] 
D. Contemporary Newspapers and Periodicals The Asiatic Journal. Iondon, 1816.

The Asiatick Researches, Vols. 1-7. Calcutta, 1788-1801.

Julius Augustus Hicky's Bengal Gazette. Calcutta, 1780-2.

The India Gazette or The Calcutta Public Advertiser, Calcutta, 1780-8.

The Calcutta Monthly Register or India Repository of Instruction and Entertainment. Calcutta, 1790-1.

Selections from the Calcutta Gazettes, 1784-1823, 5 vols. of which $1-3$ are edited by W.S. Seton-Karr, and the rest by H.D. Sandeman. Calcutta, 1864-9.

The World. Calcutta, 1791-3.

E. Contemporary Paintings and Sketches.

Daniell, Thomas, Oriental Scenery, 3 vols. Iondon, 1795-7.

D'Oyly, Charles, The Europeans in India. Iondon, 1813. , Costume of Modern India. London, 1813. Williamson, Capt. T., Oriental Field Sports. London, 1807. 
I. Collections from Contemporary Diaries, Letters, Memoirs, Pamphlets, Traveliers Accounts, Newspapers as well as Paintings.

Brown, H., editor,

Carey, W.H., editor,

Corfield, Wilmot, editor,

Winstedt, Sir R., Indian Art. Iondon, 1947. editor,

Zoffany, John,
The Sahibs. Iondon, 1948.

The Good Old Days of Hon. John Company, 2 vols. Calcutta, 1906 [1882-7]. Calcutta Faces and Places in PreCamera Days. Calcutta, 1910.

Cock Match at Lucknow, ed. by H.E.A. cotton. London, 1928 


\section{Secondary Authorities}

A. Biographies.

Arberry, A.J.,

Bert, Sir F.B.B.,

Colebrooke, Sir J.E.,

Coupland, Sir R.,

Davies, A.M.,

Feiling, Keith,

Furber, Holden,

Gleig, Rev. G.R.,

Grier, S.C.,

Impey, E.B.,

Jones, M.G.,

Kaye, Sir John

William,

Lewis, C.B.,
Asiatic Jones. Iondon, 1946.

'Sylhet' Thackerary. London, 1911.

Iife of the Honourable Mountstuart Elphinstone, 2 vols. London, 1884. The Iife of Henry Thomas Colebrooke, Iondon, 1873.

Wilberforce. Iondon, 1945 [1923].

Warren Hastings. Iondon, 1935.

Warren Hastings. Iondon, 1954.

Henry Dundas, First Viscount Melville, 1742-1811, Irondon, 1931.

Memoirs of the Iife of the Rt. Hon. Warren Hastings, 3 vols. London, 1841. The Great Procansul. Edinburgh, 1904. Memoirs of Sir Elijah Impey. Iondon, 1846.

Hannah More. Cambridge, 1952.

The Iife and Correspondence of Charles, Lord Ietcalfe, 2 vols. Iondon, 1854.

Iives of Indian officers, 2 vols. London, 18731867 .

The Iife of John Thomas. Iondon, 1873. 
Lovat-Fraser, J.A., Henry Dundas, Viscount Melville.

Morris, Henry, The Life of Charles Grant. Iondon, 1904 , The Governors-General of India, 2 vols. Madras, 1894.

Parkes, Joseph and Memoirs of Sir Philip Francis, 2 vols. Meriviale, Herman, London, 1867.

Teignmouth, Lord, Memoir of the Life and Correspondence of John, Lord Teignmouth, 2 vols. London, 1843.

Thompson, E.J., The Life of Charles, Lord Metcalfe. London, 1937.

Wilberforce, R.J. The Iife of William Wilberforce, 3 vols. and S., London, 1838.

Wright, Arnold and Sterne's Eliza: some Account of her Sclater, William Life in India : with her Letters, Iutley, written between 1757 and 1774. London, 1922. 
B. Genealogical Works

Buckland, C.E. Dictionary of Indian Biography. editor, London, 1906.

Burke, J. and Sir Landed Gentry of Great Britain and B., Ireland (edited by L.G. Pine). London, 1952.

- Peerage, Baronetage and Knightage (edited by P. lownend). London, 1963.

Burke, P. Ashworth, Family Records. London, 1897. editor,

i.

Higginbotham, J.J., Men whom India has known. Madras, 1874.

Iee, Sir Sidney and Leslie Sir Dictionary of National Biography, 66 Stephen, vols, of which 1-21 were edited by Sir Leslie Stephen, 22-6, by both and 27-66 by Sir Sidney Lee, Iondon, 1885-1901. 
C. Other Works

Ali, S.M.,

Tuni Mem (Bengali), Calcutta, 1964 (Third Impression).

Arberry, A.J.,

Oriental Essays. Iondon, 1960.

Asiaticus

(John Hawkesworth),

Calcutta in Days of Yore. Calcutta,

Aspinall, A.,

Cornwallis in Bengal. Manchester, 1931.

Auber, P.,

An Analysis of the Constitution of the East India Company. Iondon, 1826.

Barat, A.,

The Bengal Native Infantry. Calcutta, 1962.

Bartholomew, J., editor,

The Survey Gazetteer of the British Isles and Reference Atlas of Greater Iondon. Edinburgh, 1954 (Nineth Edition

Basham, A.I.,

The Wonder that was India. Calcutta, 1963.

Williuss, Basil, A.t.,

The Whig Supremacy, 1714-60. Oxford, 1939.

Bethel, J.P., editor,

Webster's Geographical Dictionary. Springfield (U.S.A.), 1949.

Bhattacharya,

Sukumar,

The East India Company and the Economy of Bengal, 1704-40. Iondon, 1954.

Bhattacharya, B.,

Bengal Renaissance. Calcutta, 1963.

Blechynden,

Kathleen,

Calcutta : Past and Present. Iondon, 1905.

Blochman, H.,

Calcutta during the last Century. calcutta, ? 1868.

Blunt, Sir E.,

The I.C.S. Iondon, 1937. 
Bradley-Birt,

Sir F.B.,

Briggs, A.,

Broome, A.,

Busteed, H.E.,

Campos, J.J.A.,

Castellani, A. and

Chalmers, A.J.,

Chaudhuri, K.N.,

Clarke, T.G.,

Cohn, B.S.,

Danvers, F.C.,

et al,

Datta, R.C.,

Derret, J.D.M.,

Dewar, D.,

Dickinson, J.,
The Story of an Indian Upland. Iondon, 1905.

The Age of Improvement. Iondon, 1959.

History of the Rise and Progress of the Bengal Army. London, 1851.

Echoes from 0ld Calcutta. Calcutta, 1908 [1888].

History of the Portuguese in Bengal. calcutta, 1919.

A Manual of Tropical Medicine. Iondon, 1919 [1910].

The English East India Company, 1600-40. Iondon, 1965.

The Fortunes of the Anglo-Indian Race. Madras, 1878.

The British in Benares: A Nineteenth Century Colonial Society. Reprinted from Comparative studies in society and History, Vol. 4, No. 2. Hague, 1962

Memorials of old Haileybury College. Iondon, 1894.

The Economic History of British India, 1757-1837. London, 1902.

Sanskrit Iegal Treatises Compiled at the Instance of the British. Stuttgart, 1961.

Bygone Days in India. Iondon, 1922.

India : its Government under a Bureaucracy. London, 1853. 
Dodwell, H., -

Embree, A.T.,

Foster, Sir W.,

Furber, H.,

Ghosal, A.K.,

Graham, H.G.,

Grant, C.,

Grant, H., and Colebrooke, E.,

Guest, Capt. F., (Reginald Edwin)

Gupta, A.C., editor,

Hart, Rev. W.H., Holzman, J.M.,

Hunter, Sir W.W.,
The Nabobs of Madras. Iondon, 1926. The Cambridge History of India, Vols. 5 and 6. London, 1929, 1958 [1932].

Charles Grant and British Rule in India. London, 1962.

John Company. Iondon 1926.

John Company at Work. Cambridge (U.S.A. 1948.

Civil Service in India under the East India Company. Calcutta, 1944.

The Social Iife of Scotland in the Eighteenth century. London, 1937 [1899] Rural Iife in Bengal. Iondon, 1860. Anglo-Indian Domestic Sketch. London, 1849.

The Anglo-Hindoostanee Hand Book. Calcutta, 1850.

Indian Cavalryman. Iondon, 1959.

Studies in the Bengal Renaissance. Jadavpur, 1958.

old Calcutta. Calcutta, 1895.

The Nabobs in England, 1760-85. New York, 1926.

The Thackerays in India and some Calcutta Graves. London, 1897.

Annals of Rural Bengal, 3 vols. Iondon, 1868.

A History of British India, 2 vols. London, 1899-1900. 
Hyde, H.B.,

Innes, It. Col. P.R.,

Jaeger, M.,

Jones, M.E., editor,

Kaye, Sir J.W.,

Kincaid, D.,

Kipling, R.,

Iong, Rev. J.,

Marshall, P.,
Parochial Annals of Bengal. Calcutta, 1901.

Imperial Gazetteer of India, 26 vols. oxford, 1908-31 (New and Revized Edition).

The History of the Bengal European Regiment. London, 1885.

Before Victoria. Iondon, 1956.

Warren Hastings in Bengal, 1772-4. oxford, 1918.

Peregrine Pultuney or Life in India, 3 vols. London, 1844.

Christianity in India. Iondon, 1859.

The English in India. Calcutta Review, 1844.

The English in India : Our Social Morality. Calcutta Review, 1844.

British Social Iife in India, 16081937. London, 1938.

Indian Tales, 3 vols. New York, 1889-90.

Peeps into Social life in Calcutta a Century Ago. Calcutta, 1868.

Calcutta in the Olden Times in Thomas Smith's Selections from the Calcutta Review, Vol. 8.

The Impeachment of Warren Hastings. London, 1965. 
Marshall, P.,

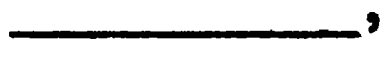

Marshman, J.C.,

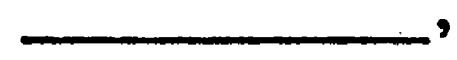

Mingay, G.E.,

Misra, B.B.,

Moon, P.,

Mïller, F. Max,

Muir, R.,

editor,

Namier, I.B.,

Narąn, V.A.,

O'Malley, I.S.S.,

Parkinson, C.N.,
The Personal Fortune of Warren Hastings: Hastings in Retirement. Bulletin of the School of Oriental and African studies (Vol. 28). London, 1965.

The Personal Fortune of Warren Hastings. The Economic History Review, Second Series (Vol. 17, No. 2). Utrecht, 1964-5.

The Iife and Times of Carey, Marshman and Ward.

Notes on the Rightbank of the River Hooghly in Smith's Selections from the Calcutta Review, Vol. 1.

English Ianded Aristocracy in the Eighteenth Century. Iondon, 1963.

The Central Administration of the East India Company, 1273-1834. Manchester, 1959.

Warren Hastings and British India. London, 1947.

India, What can it Teach us? Iondon, 1883.

The Making of British India, 1256-1858. Hanchester, 1915.

The Structure of Politics at the Accession of George III, 2 vols. London, 1929.

Jonathan Duncan and Varanasi. Calcutta, 1959.

The Indian Civil Service, 1601-1930. London, 1931.

Trade in the Eastern Seas, 1293-1813. cambridge, 1937 . 
Philips, C.H.,

editor,

Plumb, J.H.,
The East India Company, 1784-1834. Manchester, 1961 [1940].

Historians of India, Pakistan and Ceylon. London, 1961.

India. Oxford, 1949.

England in the Eighteenth Century, 1714-1815. London, 1961 [1950].

Porritt, Edward and The Unreformed House of Commons, 2 vols A., Cambridge, 1903.

Raikes, Charles, Roberts, P.E., 9

Roy, B.V., Roy, N.C.,

Ruthnaswamy, M.,

Sen, A. (Sushobhan Sarkar), Shore, P.J., Sinha, N.K., Spear, T.G.P., , Stanford, J.K., editor,
The Englishman in India. Iondon, 1867. India under Wellesley. Iondon, 1929.

History of British India under the Company and the Crown. Iondon, 1952 [1938].

old Calcutta Cameos. Calcutta, 1946. The Civil Service in India. Calcutta, 1958.

Some Influences that made the British Administrative system in India. Iondon, 1939.

Notes on the Bengal Renaissance. Calcult 1946 .

Notes on India Affairs, 2 vols. Iondon, 1837.

The Economic History of Bengal, 2 vols. Calcutta, 1956-62.

The Nabobs. London, 1963 [1932].

A History of India. Iondon, 1965.

Ladies in the Sun. Iondon, 1962. 
Stark, H.A.,

$\longrightarrow$

Madge E., Walter,

Sterndale, R.C.,

Steven Watson, J.,

Stokes, Eric,

Stokes, Whitley,

Stoequeler, J.H.,

Sutherland, Iucy S.,

Tawney, R.H.,

Thackerary, W.M.,

Thornton, Edward,

Thornton, I.H.,

Trail, H.D., and

Mann, J.S.,

editors,

Trevelyan, G.M.,

Turberville, A.S.,
Calcutta in Slavery Dajs. Calcutta, 1917.

Hostages to India. Calcutta, 1936.

East Indian Worthies. Calcutta, 1892.

An Historical Account of the Calcutta Collectorate. Calcutta, 1958 [1885].

The Reign of George III, 1760-1815. oxford, 1960 .

The English Utilitarians and India. Oxford, 1959 .

The Anglo-Indian Codes, 4 vols. Oxford, 1887-91.

The Handbook of British India. London, 1854 .

The East India Company in Eighteenth Century Politics. Oxford, 1952 .

Social History and Literature. Iondon, 1950.

Vanity Fair (ed. by Geoffrey and Kathleen Tillotson). London, 1963.

The History of the British Empire in India, 6 vols. London, 1841.

Iight and Shade in Bygone India. London, 1927.

Social England, 6 vols. Iondon, 1901-4 [1893-7].

Illustrated English Social History, 4 vols. Iondon, 1949-52.

English Men and Manners in the Eighteenth Century. Oxford, 1929. 
Turberville, A.S., Johnson's England, 2 vols. Oxford, editor, 1933.

Veitch, G.S.,

The Genesis of Parliamentary Reform. Iondon, 1913.

Weitzman, S.,

Warren Hastings and Philip Francis. Manchester, 1929.

Williams, E.N.,

Life in Georgian England. Iondon, 1962.

Wilson, H.H.,

A Glossary of Judicial and Revenue Terms and of useful words relating to the Administrations of the Government of British India. London, 1855.

Woodruff, P.,

(Philip Mason),

The Men who Ruled India, 2 vols. London, 1953-4.

Yule, H. and

Hobson-Jobson. Iondon, 1886.

Burnell, A.C., editors, 
D. Journals and Periodicals.

Bengal : Past and Present. Journal of the Calcutta Historical Society.

Bulletin of the School of Oriental and African Studies. London.

Economic History Review, Utrecht.

Selections from the Calcutta Review (edited by Thomas Smith), 11 vols. Calcutta, 1881-4.

E. Iondon University Theses and Dissertations.

Chattopadhyay, A.K., "Slavery in the Bengal Presidency under the East India Company, 1772-1843". Iondon Ph.D., 1963.

Grewal, J.S.,

"British Historical Writing from Alexander Dew to Mountstuart Elphinstone on Muslim India". London Ph.D., 1963.

Mohsin, K.M., "A Study of the Murshidabad District, 1765-93", London Ph.D., 1966.

Mukherjee, S., "Sir William Jones and the beginnings of Indology". Iondon Ph.D., 1963.

Pandey, B.N., "Sir Elijah Impey in India, 1774-83". London Ph.D., 1958

Pearson, R.,

"A Social History of the European Community in Calcutta, 1690-1911". Iondon external M.Sc., 1954 (Published as The Eastern Interlude at Calcutta in the same year). 